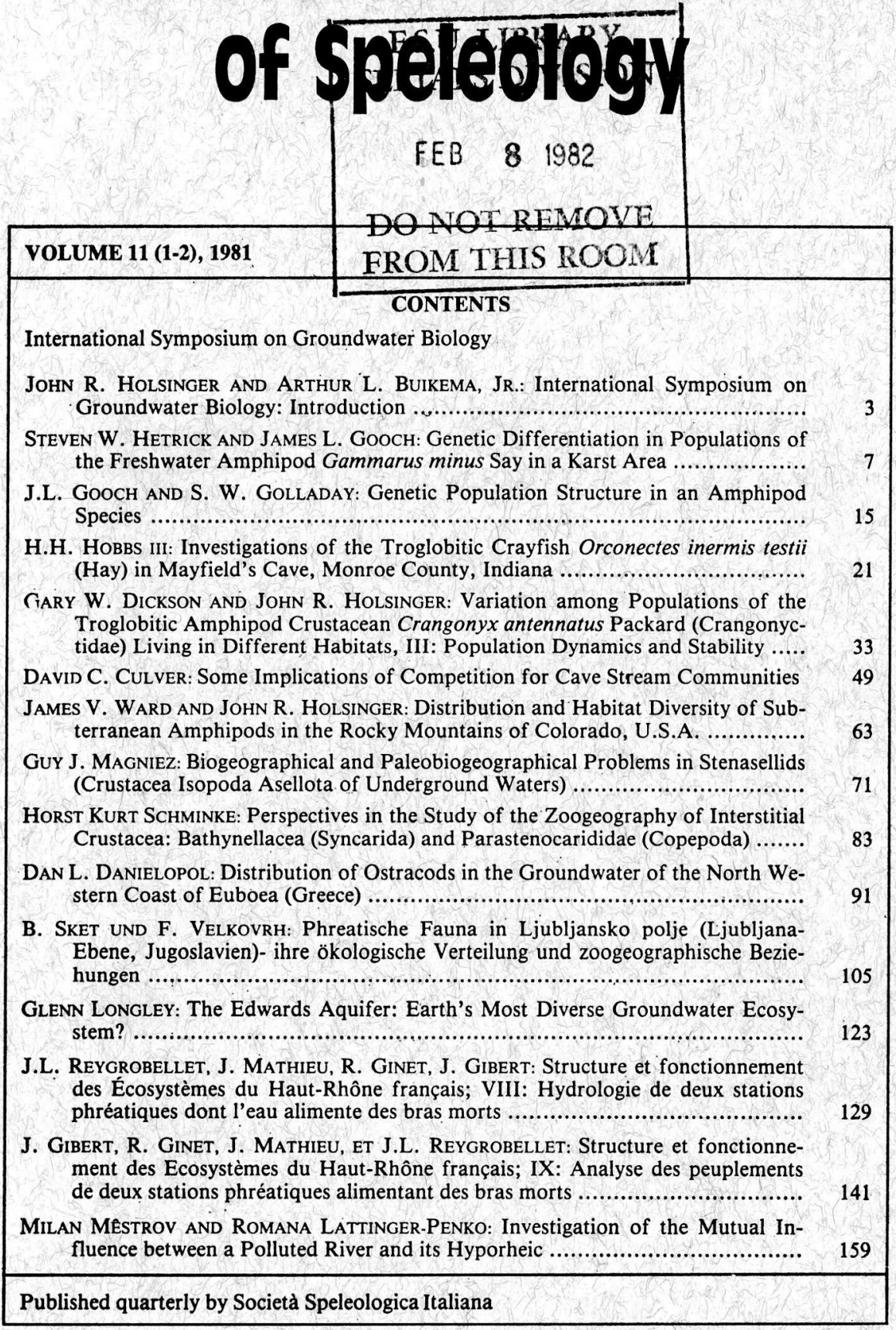




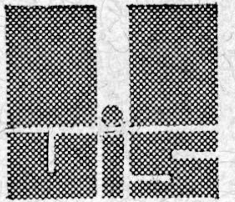

EDITOR-IN-CHIEF:

\section{ASSOCIATE EDITORS \\ Biospeleology:}

Physical Speleology: Book and News:

EDITORIAL STAFF:

ADVISORY BOARD:
VALERIO SBORDONI, Istituto di Zoologia dell'Università, Viale dell'Università, 32, 00100 Roma, Italy,

ROGER Husson, Biologie générale, Faculté des Sciences, 6 boulevard Gabriel, Dijon, France.

ARrigo Cigna, frazione Tuffo, 14023 Cocconato (Asti), Italy. Brother G. Nicholas, F.S.C. Dept. of Biology, La Salle College, Philadelphia Pa. 19141, USA.

G. CARChinI, M. CoBolli, V. Vomero, Istituto di Zoologia, Università di Roma

V. Aellen, Genève; M. ANCiauX de Faveaux, Constantine; I. ANDRASSY, Budapest; R. ARgano, Roma; D. B Alazs, Budapest; Th. C.BARR, Lexington; E. Bellard Pietri, Caracas; L. Botosaneanu, Bucarest; J. BuresCh, Sofia; A. BuRger, Neuchâtel; J. Burman, Capetown; V. Caumartin, Dijon; A. Eraso, Madrid; D. Escola, Barcelona; E.L. Friedman, Tallahassee; V.B. Gueorguiev, Sofia; F. HABE, Postojna; E. HAMILTON-SMith, Victoria; J.R. Holsinger, Norfolk; S. HuSMANN, Schlitz; H. JAKOBI, Curitiba; G.T. JEFFERSON, Cardiff; A. Nunez Jimenez, La Habana; C. Juberthie, Moulis; N Kashima, Matsuyama City; K. Matsumoto, Tokyo; R.W. MitCHELL, Lubbock; G.W. MOORE, Menlo Park; C.N. NATH, Mandsaur; J. NicoD, Marseille; T. ORGHIDAN, Bucarest; S.B. PECK, Ottawa; N. Peters, Hamburg; A. Petrochilos, Athenes; Th. L. Poulson, Chicago; E. Pretner, Postojna; Ph. Renault, Villeurbanne; S. Ruffo, Verona; T.R. ShaW, Wiltshire; H. SIEGL, Linz; B. SKET, Ljubljana; M. Sweeting, Oxford; G. Thinès, Pellenberg; H. Trimmel, Wien; A. Vigna TAglianti, Roma; N. Zalesskaja, Moscov; G.T. WARWick, Birmingham.

- Manuscripts, editorial correspondence and correspondence about publications sent in exchange should be addressed to the Editor-in-chief.

- Correspondence concerning subscriptions should be addressed to Società Speleologica Italiana, the Treasurer, Via Pacinotti 5/6, 16151 Genova, Italy.

- Annual subscription rates: Italy 20.000 It.Lire; other countries 30 U.S. Dollars.

- Payment by bank remittance to Società Speleologica Italiana, c/o Istituto bancario S. Paolo, Genoa Agency, Italy; or by cheque to Società Speleologica Italiana, the Treasurer, Via Pacinotti $5 / 6,16151$ Genova, Italy. Bank remittances must be free of every expense and bank commission.

Direttore Responsabile: A. BinI. Autoriz. Trib. Milano ${ }^{\circ} 16$ del 12.1.1979. Printed in Italy by Stamperia Wage - Roma. 


\section{INTERNATIONAL SYMPOSIUM ON}

\section{GROUNDWATER BIOLOGY}

Symposium held in 1978 at Blacksburg, Virginia, U.S.A. 



\title{
International Symposium on Groundwater Biology: Introduction
}

\author{
John R. Holsinger* \\ and \\ Arthur L. Buikema, Jr.**
}

The International Symposium on Groundwater Biology, a combination of the 4th International Colloquium on Gammarus and Niphargus and the 2nd International Symposium on Groundwater Ecology, was held in Blacksburg, Virginia, during the week of September 10-16, 1978. The precedent for combining these two meetings was set in 1975 when the two groups first met together at the Max-Planck-Instituts für Limnologie in Schlitz, West Germany. The success of the Schlitz meeting, and the high degree of overlap between the research interests of amphipod workers and groundwater ecologists, made it desirable to hold a second combined meeting in 1978. Blacksburg was ideally suited for a conference of this nature because of its close proximity to numerous karst groundwater systems and amphipod habitats. The Symposium was co-sponsored by Old Dominion University and Virginia Polytechnic Institute and State University and supported in part by a grant from the National Science Foundation.

In addition to the traditional goals of international symposia, such as the exchange of information, hypotheses, and techniques among scientists from different countries, a major reason for meeting in the United States was to stimulate future research in groundwater ecology in North America. Although aquatic cave ecosystems in North America have received considerable attention in recent years, other types of groundwater ecosystems, like those associated with the hyporheic or parafluvial zone beneath surface or cave streams, have remained little investigated on this continent. In contrast, this important subterranean life zone has been intensively studied in Europe, and the resulting literature has proliferated. Based primarily on results obtained by European researchers, the potential wealth of new taxa that remain to be discovered in the hyporheic environment in North America is estimated to be great. Moreover, the population dynamics and community structure and function of the hyporheic promises to be a fertile area of investigation in the coming years. One rather simple but very useful piece of equipment widely

* Department of Biological Sciences, Old Dominion University, Norfolk, Virginia 23508, U.S.A.

** University Center for Environmental Studies, Virginia Polytechnic Institute and State University, Blacksburg, Virginia 24061, U.S.A. 
employed in Europe for the extraction of interstitial organisms from hyporheic habitats is the Bou-Rouch pump, perfected some years ago by French scientists. Since it has rarely been used in North America, its demonstration by European workers at the Blacksburg conference proved extremely valuable to North Americans.

As reflected to some extent by the papers on amphipods presented at the Schlitz meeting, and to a much greater extent by those presented at Blacksburg, it is apparent that participation in Gammarus-Niphargus colloquia is no longer confined to those who conduct research on these two genera. Although this was the original intent of European workers in the late 1960s and early 1970s (cf., meetings in Verona, Karlsruhe, and Lyon), the meetings have evolved into far broader affairs that presently encompass research being done on many other genera of gammarid amphipods outside of Europe. Thus, retention of the name "Gammarus and Niphargus Colloquium» is now more symbolic than anything else. The great abundance and taxonomic diversity of gammarid amphipods in groundwater ecosystems throughout most of the world has resulted in the use of these organisms in numerous studies on groundwater biology. It is appropriate, then, that a conference on groundwater ecology should include current results from amphipod research, especially in freshwater systems, and a conference on amphipods should be concerned with research on groundwater ecosystems. That the workers in these two areas of research have much in common was clearly demonstrated both in Schlitz and Blacksburg. No attempt was made at the Blacksburg meeting to separate the amphipod and groundwater papers into discrete categories.

Sixty persons, including spouses, representing 14 countries, registered for the Symposium. Twenty participants were from outside of North America. A total of 39 papers covering a variety of topics was presented in eight formal paper sessions. Among the subjects covered were various aspects of the systematics, zoogeography, ecology, genetics, anatomy, and physiology of gammarid amphipods (primarily from freshwater habitats); zoogeography of subterranean copepods, ostracods, and isopods; ecology of cave crayfishes; and observations on faunal composition and species interactions in hyporheic, phreatic, and cave groundwater ecosystems.

In addition to the formal papers, four moderated discussion sessions were held. These were of particular interest and benefit because of their broad application to many of the problems currently confronting groundwater ecologists and amphipodologists. The topics and moderators were:

(1) Strategies for the production of endangered and threatened groundwater species and ecosystems - Dr. J. E. Cooper.

(2) Ecological classification of groundwater fauna and standardization of groundwater biotope and ecosystem terminology - Dr. H.K. Schminke.

(3) Revisionary concepts of gammaroidean amphipod taxonomy, with emphasis on ancestral and derived characters, evolutionary patterns and creation of higher taxa - Dr. E.L. Bousfield. pol.

(4) Sampling techniques for groundwater fauna - Dr. D.L. Danielo- 
Highlighting the activities at mid-week was an all day field excursion to the Ward Cove-Maiden Spring karst area, a valley floored with Middle Ordovician limestone in Tazewell County, Virginia. Here conferees were treated to first-hand observations of two distinctly different subterranean stream ecosystems in the large Fallen Rock Cave system and were given the opportunity to collect amphipods from a limestone spring. In addition to the midconference field trip, two optional post-conference trips were offered: one to visit cave and karst groundwater ecosystems in the Powell Valley of southwestern Virginia and eastern Tennessee, and the other to see groundwater habitats in the Great Dismal Swamp in southeastern Virginia.

The papers given at the Symposium are being published as Proceedings. Those dealing more generally with groundwater ecology are being published in this issue. Those concerned strictly with amphipod biology are being published in a special supplement to Crustaceana.

The manuscripts published herein were reviewed by members of the Symposium Coordinating Committee. Members of the committee were:

Dr. J.L. Barnard (Smithsonian Institution)

Dr. E.L. Bousfield (National Museums of Canada)

Dr. T.E. Bowman (Smithsonian Institution)

Dr. J.E. Cooper (North Carolina State Museum)

Dr. D.C. Culver (Northwestern University)

Technical editorial assistance was provided by Ms. Darla Donald.

It has been agreed that a third combined meeting will be held near Lodz, Poland, in September 1981. This meeting is being organized by Drs. K. Jaẑdẑewski and A. W. Skalski.

Symposium Co-Chairman and Co-Editors of the Proceedings on Groundwater Ecology:

Dr. John R. Holsinger (Old Dominion University)

Dr. Arthur L. Buikema, Jr. (Virginia Polytechnic Institute and State University)

\section{List of papers on Biology of Gammaridean Amphipods}

(Published in Crustaceana, Supplement 6, 1980)

J.L. Barnard and G. S. Karaman - "Classification of Gammarid Amphipoda"

J.R. Holsinger and A.W. Skalski - "The Taxonomy and Systematic Status of Crangonyx paxi Schellenberg (Crangonyctidae)",

T. Gledhill - "Designation and Description of the Lectotype of Niphargus fontanus Bate (Crustacea: Amphipoda)",

A.W. Skalski — “The Variability and Systematic Position of Three Species of Niphargus from the Caucasus",

K.S. Lee and H.S. Kim - "On the Geographical Distribution and Variation of Freshwater Gammarus (Amphipoda: Gammaridae) in Korea, Including Descriptions of Four New Species",

G.A. Cole - "The Mandibular Palps of North American Freshwater Species of Gammarus

K. Jaẑdžewski - "Range Extensions of Some Gammaridean Species in European Inland Waters Caused by Human Activity",

B.R. MacPherson and V.J. Steele - "Microanatomy of the Central Nervous System of Gammarus setosus Dementieva (Crustacea, Amphipoda): The Suboesophageal Ganglion and Ventral Ganglion Chain", 
A.L. Buikema, Jr., A. Chester, and H.R. Steeves, III - "Intersexuality in Gammarus minus Say"

L. Vassallo and D.H. Steele - "Survival and Growth of Young Gammarus lawrencianus on Different Diets"

J. Mathieu and J. Gibert - "Evolution des Teneurs en Proteines, Glucides et Lipides de Niphargus rhenorhodanensis (Crustaces, Amphipodes Phreatobies) Comparee entre L'elevage en Milieu Naturel Reconstitue et le Jeune Experimental'

J. Gibert and J. Mathieu - "Relations entre les Teneurs en Proteines, Glucides, et Lipides au Cours du Jeune Experimental, Chez Deux Especes de Niphargus (Crustace, Amphipode) Peuplant des Biotopes Differents"

C. Roux, A.L. Roux, and Y. Opdam - "Repartition Ecologique et Metabolisme Respiratoire de Gammarus roeseli (Crustace, Amphipode)"

J. Mathieu - "Activite Locomotrice et Metabolisme Respiratoire a $11^{\circ} \mathrm{C}$ de L'Amphipode Troglobie Niphargus rhenorhondanensis"

H.H. Costa - "The Effects of Some Heavy Metal Pollutants on the Heart Beat of Gammarus pulex (L)"

M. Hiroki - "Relation between the Two Diel Phenomena Shown by Freshwater Gammarids --Drift and Vertical Migration"

M.P.D. Meijering - "Drift, Upstream-Migration, and Population Dynamics of Gammarus fossarum Koch, 1835",

F: Jenio - "The Life Cycle and Ecology of Gammarus troglophilus Hubricht and Mackin (Amphipode: Gammaridae)"

A. Goedmakers - "Microgeographic Races of Gammarus forssarum Koch, 1836 (Amphipoda, Crustacea)"

S. Pinkster and N.W. Broodbakker - "The Influence of Environmental Factors on Distribution and Reproductive Success of Eulimnogammarus obtusatus (Dahl, 1938) and Other Estuarine Gammarids"

J. Dessaix and A.L. Roux - "Structure and Dynamics of the French Upper Rhone Ecosystems, An Estimation of the Secondary Production of Gammarids in the Main Stream".

The following papers were given at the Symposium, but are not being published as a part of the Proceedings:

E.L. Bousfield - "A Revised Classification and Phylogeny of Amphipod Crustaceans"

H.P. Bulnheim - "Studies on the Physiological Ecology of Five Euryhaline Gammarus Species"

A. Goedmakers and S. Pinkster - "Migration of Freshwater Gammarids"

G. Longley and J.R. Holsinger - "Subterranean Amphipod Population Dynamics Based on Organisms Sampled From an Artesian Well in Texas". 
Int. J. Speleol. 11 (1981), pp. 7-13.

\title{
Genetic Differentiation in Populations of the Freshwater Amphipod Gammarus minus Say in a Karst Area
}

\author{
Steven W. Hetrick* \\ and \\ James L. Gooch**
}

\begin{abstract}
SUMMARY
The genetic makeup of populations in a particular geographic area should conform, in part, to environmental structure. Three polymorphic enzyme loci in the amphipod Gammarus minus are geographically differentiated in gene frequencies in the mid-Appalachian Mountains of the eastern United States, and genetic breaks usually coincide with topographical features and stream divides. Areas with well integrated drainage systems have a high degree of genetic uniformity.
\end{abstract}

\section{INTRODUCTION}

One of the underlying ideas in evolutionary biology is that a highly structured environment with well delineated dispersal barriers and routes of migration should profoundly affect the genetic makeup of the populations within it. Thus, genetic patterns of an aquatic organism should correlate well with drainage patterns and local hydrology of a given geographic area. This study examined two phenomena: areas of change and an area of great uniformity in the regional pattern of allozyme loci in the amphipod crustacean Gammarus minus Say in a karst area of southwestern West Virginia. This was done to see if the areas of change correspond to presumed dispersal barriers. Also the potential is great for a species to maintain gene flow throughout a karst area by dispersal through interconnected caves and water filled solution channels (Culver, 1970, 1971; Holsinger, 1967, 1969; Holsinger \& Culver, 1970; Poulson \& White, 1969; Avise \& Selander, 1972), such as in Davis Spring Basin (DSB).

Gammarus minus is well suited for such a study. Populations are highly differentiated in allele frequencies at from one to three of the loci under investigation. The species is limited principally to springs, spring runs, and cave streams of limestone areas. Also, since it has no specific migratory stage in its

* Department of Biological Sciences Old Dominion University Norfolk, Virginia 23508 (Present address: Bureau of Shell Fish Sanitation, White Stone, Virginia 22578)

** Department of Biology Juniata College Huntingdon, Pennsylvania 16652. 
life history, populations are semi-disjunct and partially isolated from others, even in local drainage systems, and isolated to a greater extent from populations in other streams and other limestone areas.

Gooch and Hetrick (1979) report on a number of geographic areas in which populations showed sharp genetic changes in contrast to other areas which were genetically uniform. This study examines four of these areas in more detail to determine the extent to which hydrology influences these genetic patterns.

\section{MATERIALS AND METHODS}

We examined three allozyme systems coded by polymorphic loci (malate dehydrogenase, Mdh-1; phosphoglucose isomerase, Pgi-l; peptidase, Pep-l) using electrophoretic techniques on cave and spring populations in karst areas of southeastern West Virginia (Gooch and Hetrick, 1979). A computer plot of allele isofrequency lines for the most common allele at each locus $\left(M d h-I^{d}, P g i-I^{c}\right.$, and $\left.P e p-I^{d}\right)$ was used to examine the areas. Isofrequency maps of alleles are adapted from computer-drawn contour diagrams using the Numerical Surface Techniques and Contour Map Plotting set of programs 1130-(X-11X) for the IBM 1130 computer.

The study area lies in that part of the Greenbrier Valley bounded on the north by Droop Mountain in Pocahontas County and extending south about $70 \mathrm{~km}$ into Monroe County, West Virginia. Karst topography is highly developed, especially in the Great Savannah karst of south-central Greenbrier County and in Monroe County south of the Greembrier River (Jones, 1973).

Areas and localities sampled are as follows (see Fig. 1): Northern Greenbrier area (NG): 1. Martens Cave, 2. Lobelia Spring, 3. Marthas Cave, 4. Taylors Spring; Spring Creek area (SC): 5. Route $\neq 219$ Spring, 6. Buckeye Creek Cave, 7. Culverson Creek Spring, 8. The Hole Cave; Davis Spring Basin (DSB): 9. Coffman Cave, 10. McClungs Cave, 11. Benedicts Cave, 12. Davis Spring; Davis Hollow Basin (DHB): 13. Sinks of the Run Cave, 14. General Davis Cave; Southern Greenbrier (SGR): 15. Organ Cave, 16. Dixons Spring, 17. Spring South of Second Creek, 18. Burnside Branch Cave; Ordovician Limestone Belt (OLB): 19. Kitchen Creek Spring, 20. Pattons Cave Spring, 21. Zenith Spring.

\section{RESULTS AND DISCUSSION}

Figure 1 shows allele frequencies for the three polymorphic loci examined. Martens Cave and Lobelia Spring populations in the Lobelia section of Greenbrier limestone crop out on the west side of Droop Mountain, while Marthas Cave is in the main NE-SW section cropping out to the east. Droop Mountain is potentially a formidable dispersal barrier for populations on either side and might also tend to impede north-south dispersal. However, drainage of the limestone outcropping on the northwestern side of Droop 


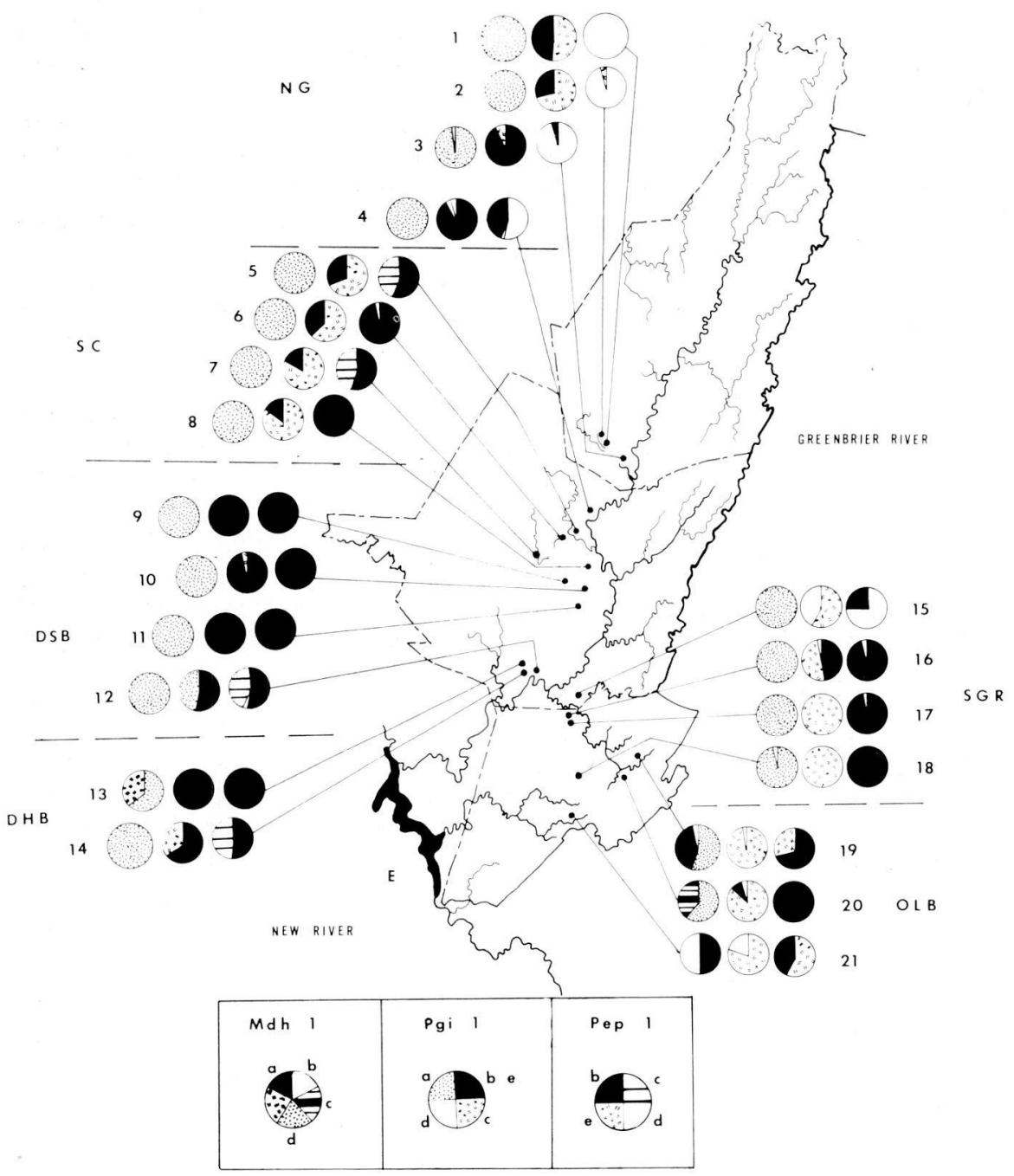

Fig. 1. Map showing location of sampled populations in three counties of southeastern West Virginia. Allele frequencies at the $M d h-l, P g i-l$, and Pep-l loci are represented respectively from left to right for each location and are indicated as percentages of circles. 
Mountain flows under the mountain and a portion of it flows through the third Northern Greenbrier (NG) site, Marthas Cave, before resurging and flowing into the Greenbrier River (Wolfe, 1964; White and Schmidt, 1966). It is thus easy to envision amphipod dispersal under the spur of Droop Mountain. The hydrology, the Pep-l alleles that characterize this area (Fig. 1), and the bunching of Pep- $I^{b}$ isolines at the area border (Fig. 2A) suggest that these populations have been relatively isolated from those of surrounding geographic areas. Also, the Pgi- 1 c isoline patterns (Fig. 2A) outline the Droop Mountain barrier within (NG), separating the Martens Cave and Lobelia Spring populations from Marthas Cave on the main southeastern belt.

The Spring Creek drainage basin (SC) is another potential dispersal barrier representing the local base level of the water table and receives discharge of subsurface drainage. As described by Jones (1973), subsurface drainage of the area is divided into several sub-basins, namely Culverson Creek, Buckeye Creek, and The Hole Cave, all of which resurge into Spring Creek. Our experience and that of Holsinger and Culver (1970) strongly suggest that G. minus is absent from large streams like Spring Creek, except as occasional drifting individuals. However, G. minus is found in the springs where each of these sub-basins resurge into Spring Creek. These springs are located at almost equally spaced points along Spring Creek. This distribution of springs could aid in stepping stone dispersal of $G$. minus into various sub-basins and thus produce a pattern of genetic homogeneity within the Spring Creek drainage basin.

Populations within the Spring Creek drainage are relatively homogeneous for both Pep and Pgi. The isolines for Pgi-1c are bunched slightly between NG and SC, but the frequency of $c$ falls sharply almost to zero between SC and DSB (Fig. 1 and 2A). This genetic discontinuity coincides with the subterranean drainage divide between The Hole Cave, which discharges northeastward into Spring Creek, and the vast cave network of the DSB, draining southwest. The divide is only a few hundred meters wide (Jones, 1973 Mapa). Also, Pep- $I^{b}$ shows a steepening of the cline near the NG-SC boundary, but, unlike $P g i-I^{c}$, there is no corresponding break across the SC-DSB divide. These data suggest that Spring Creek itself is not an important dispersal barrier within the basin, although the basin as a whole appears to isolate areas to the north and south.

One of the most interesting and largest of the areas studied is the Davis Spring Basin (DSB). Its northern segment drains through Higginbotham's Cave and then through Coffman Cave. Coffman Cave has been dye traced to Davis Spring (Jones, 1973). Drainage in the eastern part of DSB is primarily subsurface through extensive, well integrated cave systems. Populations from a number of these caves were sampled. Although the caves have a dendritic pattern, their general orientation and water flow are southwest. Davis Spring appears to be the point of resurgence for this entire basin (Jones, 1973). Obviously this area has a well integrated subterranean drainage system, and the potential for dispersal and consequent gene flow is great. All populations of this area are genetically homogeneous at all three loci (Fig. 1). Both electrophoretic and hydrologic data lend considerable weight to the proposal that at 


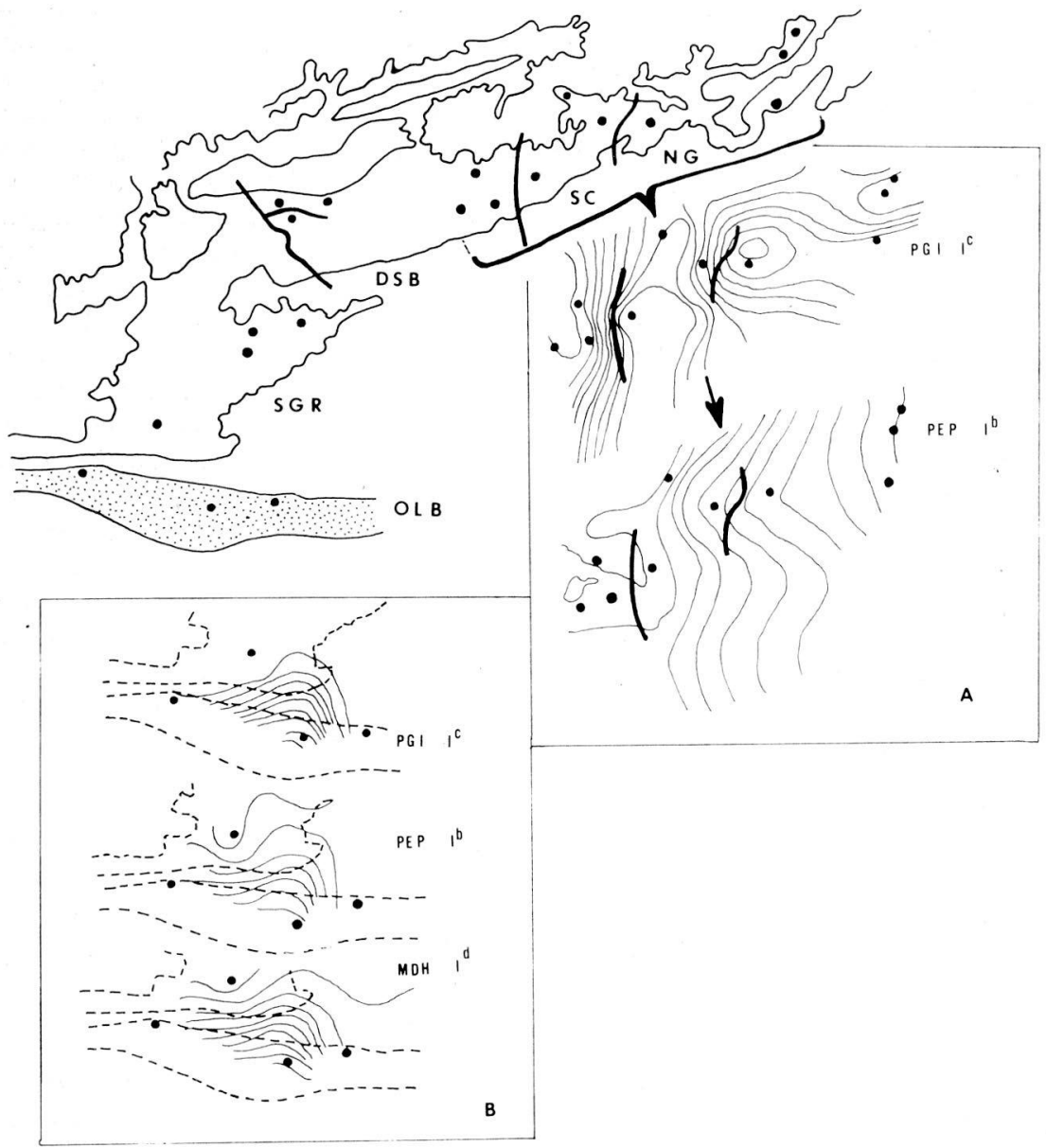

Fig. 2. Maps showing isofrequency lines of the most common alleles at each locus, respectively $P g i-I^{c}, P e p-I^{b}$ and $M d h-I^{d}$. Isolines for areas NG, SC, and DSB boundaries are shown in map A, those for isolines between SGR and OLB in map B. Upper map is of the Greenbrier Limestone outcrop (solid-lined borders and open area) and the Ordovician limestone belt (solid-lined borders with stippling). Heavy lines represent boundaries of a priori defined areas. 
least intermittent gene flow is occurring or has occurred between these populations.

The Ordovician Limestone Belt (OLB) consists of a narrow band of Ordovician limestone cropping out in the eastern part of Monroe County, West Virginia, occupying the valley floor on the west side of Peters Mountain and Back Valley (Davies, 1965). Two major surface drainage systems, Greenbrier River and New River, are found here. Both Kitchen Creek Spring and Patton's Cave Spring are within the Greenbrier drainage while Zenith Spring is in the New River drainage. Both alleles and frequencies vary considerably between sites. However, OLB populations exhibit a pattern of heterogeneity which corresponds with surface drainage patterns. All three loci demonstrate a high isoline density between OLB and Southern Greenbrier area (SGR) populations (Fig. 2B), indicating a high degree of genetic differentiation. The total pattern revealed by these data is not surprising since the limestone here is narrow, without a well integrated subterranean drainage system and is geologically isolated from the other portions of the study area on Greenbrier Limestone. The SGR-OLB barrier to subsurface connectivity is associated with the genetic discontinuity.

Populations have been examined within the James River drainage which are also geologically isolated from OLB by a series of clastic ridges. These populations are also sharply differentiated from OLB populations. This reinforces our conclusion that hydrology can markedly affect the genetic pattern of an area.

\section{RÉSUMÉ}

La composition génotypique des populations d'une aire géographique particulière serait partiellement fonction de la structure de leur environnement. Trois loci enzymatiques polymorphes de l'Amphipode Gammarus minus montrent des fréquences géniques présentant des différences géographiques dans la région moyenne des Monts Appalaches, à l'Est des Etats-Unis. Les discontinuités génétiques coïncident habituellement avec des éléments de la topographie ou les lignes de partage des eaux. Les aires où le réseau hydrographique est très cohérent montrent un degré élevé d'uniformité génétique.

\section{LITERATURE}

AVISE, J.C., and R.K. SELANDER. 1972. Evolutionary genetics of cave dwelling fishes of the genus Astyanax. Evolution 26:1-19.

CULVER, D.C. 1970. Analysis of simple cave communities. I. Caves as islands. Evolution 24:463-474.

CULVER, D.C. 1971. Caves as archipelagoes. Bull. Nat. Speleol. Soc. 33(2):97-100.

DAVIES, W.E. 1965. Caverns of West Virginia. W. Va. Geol. Surv. 19A.

GOOCH, J.L., and S.W. HETRICK. 1979. The relationship of genetic structure to environmental structure: Gammarus minus in a karst area. Evolution 33(1):192-206.

HOLSINGER, J.R. 1967. Systematics, speciation, and distribution of the subterranean amphipod genus Stygonectes (Gammaridae). U.S. Nat. Mus. Bull. 259.

HOLSINGER, J.R. 1969. Biogeography of the freshwater amphipod crustaceans (Gammaridae) of the central and southern Appalachians. In: The distributional history of the biota of the southern Appalachians. Part I: Invertebrates. Research Division Monograph I, VPI Press, Blacksburg, Va.:19/5D. 
HOLSINGER, J.R. and D.C. CULVER. 1970. Morphological variation in Gammarus minus Say (Amphipoda, Gammaridae) with emphasis on subterranean forms. Postilla 146:1-24

JONES, W.K. 1973. Hydrology of limestone karst in Greenbrier County, West Virginia. U.S. Geol. Surv. Bull. 36:1-49.

POULSON, T.L., and W.B. WHITE. 1969. The cave environment. Science 165:971-981.

WHITE, W., and V. SCHMIDT. 1966. Hydrology of a karst area in east-central West Virginia. Water Resour. Res. 2:549-560.

WOLFE, T.E. 1964. Cavern development in the Greenbrier Series, West Virginia. Bull. Nat. Speleo. Soc. 26(2):37-59. 

Int. J. Speleol. 11 (1981), pp. 15-20.

\title{
Genetic Population Structure in an Amphipod Species
}

\author{
J.L. Gooch* \\ and S.W. Golladay**
}

\begin{abstract}
SUMMARY
Genetic structure of a species should conform, in part, to environmental structure. Three polymorphic enzyme loci in the amphipod Gammarus minus Say are geographically differentiated in gene frequencies in the mid-Appalachian Mountains of the eastern United States, and genetic breaks usually coincide with topographical features and stream divides. Considering alleles as migrational markers, it is expected that heterozygosity would decrease upstream in isolated drainage basins, increase in the headwaters of adjacent but oppositely flowing streams in which gene exchange was occurring between genetically differentiated populations, and increase in sites near regional master streams. These genetic patterns were found to exist in an area near the Juniata River in central Pennsylvania.
\end{abstract}

\section{INTRODUCTION}

It is an article of faith among ecological geneticists that genetic patterns exist in natural populations, even if the "patterns" are stochastically varying gene frequencies that fit only theoretical models of random drift. A few examples of relatively clear-cut and environmentally-correlated genetic patterns are known in animals and plants (e.g., Johnson, 1971; Koehn, 1969; Schopf, 1973). More commonly geographical patterns are roughly delineated and their origins are speculative and perhaps multiple (e.g., Aspinwall, 1974; Cockley, et al., 1977; Gorman, et al., 1975).

Geographic-genetic patterns are likely to be sharpest in highly structured environments. There the prominent environmental grain should be maximally imposed on the geographical components of species genetic structure. Regional genetic patterns are distinct in Gammarus minus Say (Amphipoda) in springs and spring-fed streams of the mid-Appalachian Mountains of the eastern United States. We investigated three allozyme systems coded by polymorphic loci (malate dehydrogenase, $M d h-1$; phosphoglucose isomerase, Pgi1; peptidase, Pep-I) using electrophoretic techniques on cave and spring populations in karst areas of southeastern West Virginia (Gooch and Hetrick, 1979). Gene frequencies were found to be highly differentiated geographically, and genetic breaks usually coincided with surface topographic and subsur-

* Biology Department, Juniata College Huntingdon, PA 16652, U.S.A.

** Present address: Department of Biology, Virginia Polytechnic Institute and State University, Blacksburg, VA 24061, U.S.A. . 
face karstic divides. This study has recently been extended to include 175 populations over a four state area. A portion of this wider study is reported here, centering on an area of central Pennsylvania.

The study area lies in a typical segment of the folded Appalachians characterized by linear southwest-trending clastic ridges separated by shale and carbonate valleys. Peak abundances of Gammarus minus are in the carbonate valleys. The drainage forms a trellis pattern, with smaller streams occupying strike valleys and larger trunk streams flowing usually southeast across the geological structure and breaching the ridges through water gaps.

Amphipod populations have undergone marked differentiation in gene frequencies at any one or more of the three loci. No correlation has been detected, however, between the frequency of any allele and substrate composition, sediment size and texture, temperature, vegetation type, water hardness, or other variables (Gooch, unpublished data). Therefore alleles will be treated here solely as markers or tags of amphipod movements, which are undoubtedly channelized along surface streams in most cases. Phoresy on large animals, stream piracy, and especially subsurface movements in limestone areas are usually subordinate factors in migration.

\section{RESULTS AND DISCUSSION}

Figure 1 depicts patterns of genetic variability or heterozygosity hypothetically created by gene exchange among genetically differentiated populations. In Fig. 1A a small drainage basin is shown enclosed by clastic ridges on three sides. There is no water access into the basin except upstream from the trunk stream. Heterozygosity decreases upstream, reflecting the multiple founding episodes required to complete the colonization of the entire basin. The process is schematized in Fig. 1C. A hypothetical small population initially occupies a site near the stream mouth. A representative amphipod has the 3-locus genotype $a^{\prime} a b b c^{\prime} c$ and is thus heterozygous at two of three loci (67\% polymorphic). Subsequently a few individuals, or perhaps a single brooding female, colonize the central area of the basin and $a$ ' is not represented among the founders. Only the $c$ locus remains polymorphic (33\%). Finally the headwater reaches are colonized, but with the further chance loss of the $c$ allele. The headwater populations are now monomorphic for all three loci $(0 \%)$, and the pattern of diminishing heterozygosity upstream is completed.

In Fig. 1B heterozygosity is shown highest in headwaters of juxtaposed and oppositely-flowing drainages separated by a low divide. As in Fig. 1A, upstream populations become increasingly monomorphic and genetically differentiated. Here, however, the divide is an incomplete barrier to migration, and gene exchange occurs by one of the mechanisms not requiring continuity of surface drainage listed previously. Local gene exchange gives rise to a headwater zone of high heterozygosity.

A regional trunk stream with tributaries is shown in Fig. 1C. Heterozygosity is highest in populations nearest the master stream and declines in all directions. This is because: (1) the smallest number of colonizing episodes is 
required to initially populate the downstream habitable reaches of the tributaries, and (2) the trunk stream serves as the primary avenue of continuing gene exchange among established populations. Continuing gene exchange is probably intermittent and not extensive. We have never found permanent populations of G. minus in higher than third-order streams, although we have seined isolated individuals from large streams.

The heterozygosity patterns of Fig. 1 are singly exhibited in several places in the study area. We will describe a locality that exemplifies in mixed form all three patterns. Fig. 2 shows an approximately $1100 \mathrm{~km}^{2}$ area of central Pennsylvania. Two branches of the Juniata River flowing southeastward traverse the long, $350 \mathrm{~m}$ high ridge of Tussey Mountain through two water gaps and then unite to form the Juniata River proper. Pie sectors depict frequencies of the $b, f$ and $g$ alleles at the Mdh-l locus of populations in strike valleys paralleling the ridge on both sides. East of Tussey Mountain, 11 northern populations remote from the water gaps ( 3 shown and 8 additional) are virtually monomorphic for $f$, and 22 populations well south of the gaps ( 3 shown, 19 additional) are also fixed for $f$. Northwest of the ridge, in Nittany Valley, the $f$ allele is rare and $b$ and $g$ predominate. To the southwest all three alleles are in high frequency.

Clearly the Tussey Mountain barrier has permitted strong genetic differentiation to develop in the flanking valleys. The Nei index of genetic similarity (Nei, 1972) was determined for the three loci between five populations bordering Spruce Creek northwest of the ridge, and five near Shavers Creek and Standing Stone Creek northeast of the ridge. An index of 0 denotes no alleles in common and 1.0 complete genic identity. The mean Nei index of west versus east side populations is $0.37 \pm 0.02$ (indices are not normally distributed, so SE approximates confidence in mean). In contrast, the index among western populations is $0.90 \pm 0.03$ and among eastern $0.99 \pm 0.01$.

Near the two water gaps on the eastern or downstream side the pattern of regional differentiation breaks down. The 16 populations nearest the gap are genetically mixed; the $b$ and $g$ alleles, elsewhere confined west of Tussey Mountain, exist in high frequency along with $f$. Fig. 2 shows that the zone of mixing extends about $20 \mathrm{~km}$ to the south and at least $12 \mathrm{~km}$ north and east. There is less evidence for gene exchange westward, except for an appreciable frequency of $f$ in the Nittany Valley population nearest the water gaps.

Environmental factors are not tangibly different in the two flanking valleys or adjacent to the water gaps. The uniform pattern of $f$-fixation northeast and southeast of the gaps indicates that this was probably the antecedent patten and the mixed zone east of the gaps was superimposed. It is highly probable that individuals migrating through the gaps via the Juniata River have introduced $b$ and $g$ into the eastern populations. The process may have been episodic or continuous. We envision as the most likely model a gradual site-by-site gene diffusion. Eastern populations heavily dominated by $b$ and $g$ alleles may have been initially founded by western migrants.

The pattern of Fig. 1A, headward decline of heterozygosity in an isolated drainage basin, is demonstrated by Shavers Creek Valley (Fig. 2, upper right). This valley is part of a large synclinal structure hemmed in by clastic 

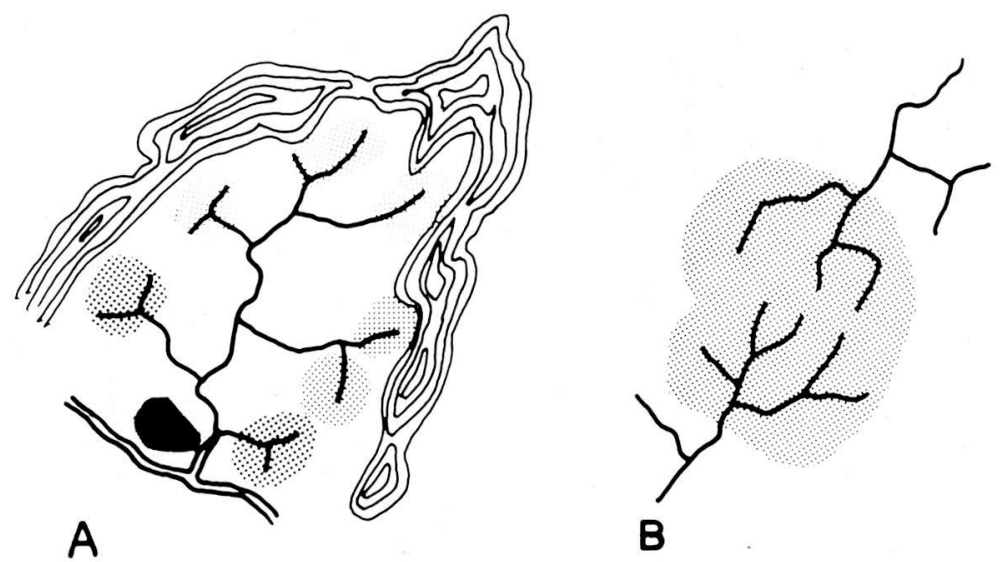

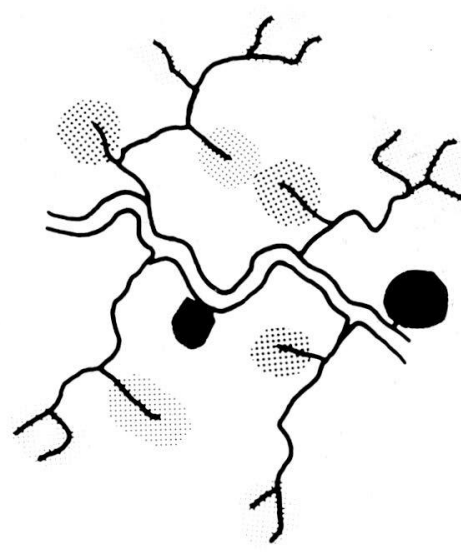

C

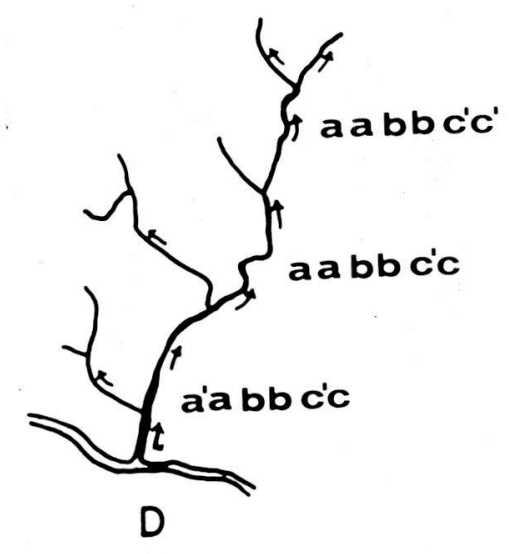

Fig. 1. Models of genetic variability in drainage basins. Heterozygosity increases with increase in stippling density.

ridges in all directions except the southwest. Average heterozygosity for three loci diminishes from 0.254 in five downstream populations to 0.074 in 10 upstream populations.

The pattern of Fig. 1B, increased heterozygosity near the divide between drainages with differentiated populations, in not found in simple form in the study area. The general concetp is demonstrated by the entire zone east of the water gaps where differentiated populations in adjacent valley drainages co- 


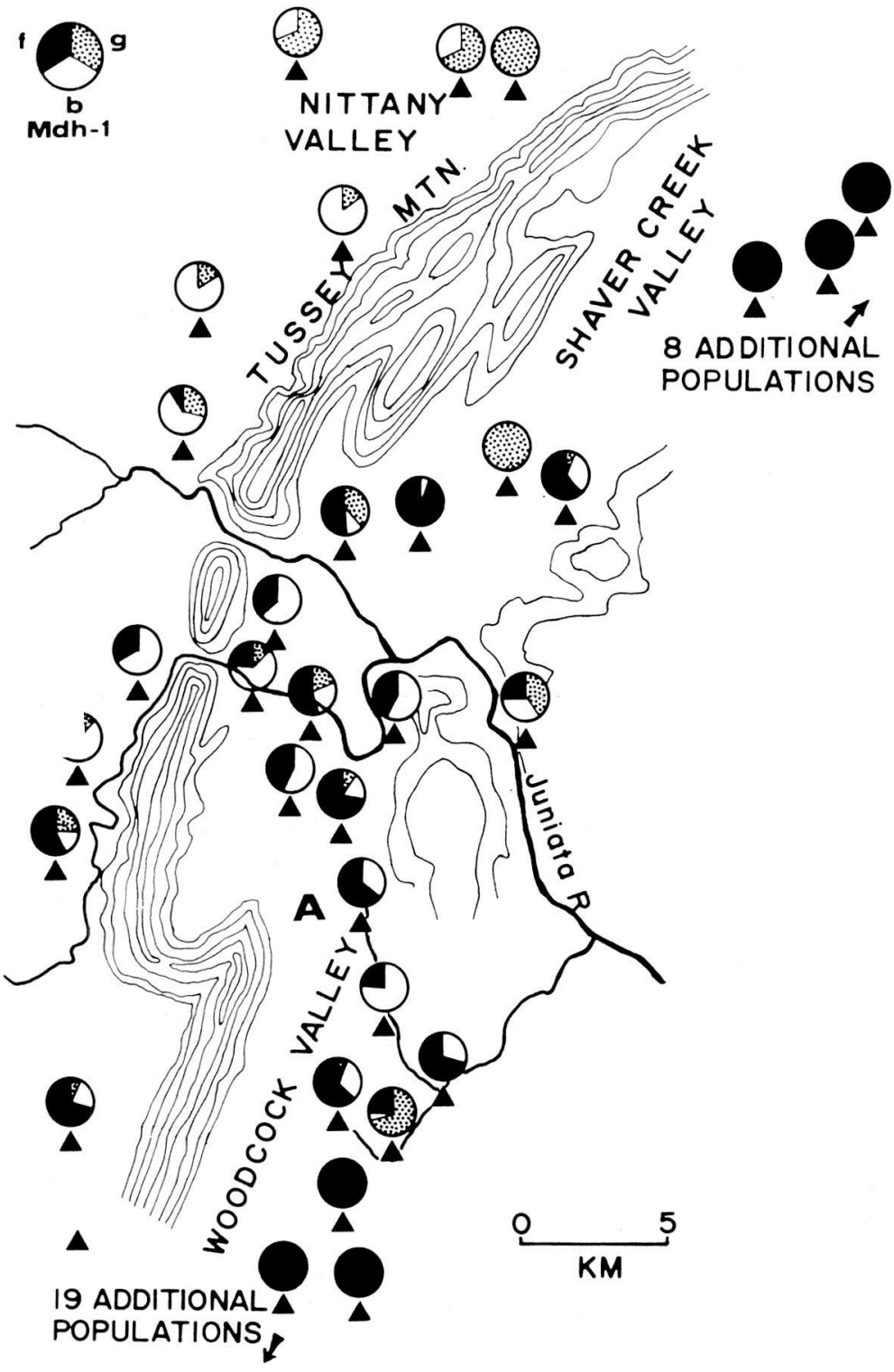

Fig. 2. Study area in central Pennsylvania. Population sites are designated by triangles, allele frequencies by sectors of circles. 
me into contact and increased heterozygosity is a consequence of gene exchange. The high heterozygosity band following the oppositely flowing streams in Woodcock Valley, near point " $A$ " of Fig. 2, also exemplifies this pattern.

Finally, the overall regional pattern is of increased heterozygosity associated with the regional master streams, as in Fig. 1C. The effect is locally amplified by the gene channelization imposed by the water gaps. It also exists, however, although less distinctly, along a long stretch of the Juniata River and its major branches distant from the water gaps.

\section{ZUSAMMENFASSUNG}

Die Genetische Struktur einer Art steht mit der Struktur der Umwelt teilweise im Einklang. Drei polymorphe Gene, welche die Enzyme Phosphoglucoseisomerase, Malate dehydrogenase und Peptidase codieren, differieren in der Genfrequenz in Abhängigkeit von der geographichen Lage bei dem Amphipoden Gammarus minus Say, der in den mittleren Appalachen (USA) vorkommt. Genetische Unterschiede treben gewöhnlich bein Stromverzweigungen und bei einer Änderung topographischer Merkmale auf. Betrachtet man unterschiedloche Allenfrequenzen Wanderungkennzeichen, so ist zu erwarten, daß die Heterozygotität in isolierten Biotopen flubaufwärts abnimmt. Dagegen nimmt sif sowohl in benachbarten, engegengesetzt fliebenden Oberläufen, in denen Genaustausch zwischen genetisch verschiedenen Populationen vorkommt, als auch im Einflußbereich naher Hauptflüsse zu. Ein derartiger genetischer Zussamenhang wurde in der Umgebung des Juniata Rivers in Zentralpennsylvanien, U.S.A., fest gestellt.

\section{LITERATURE}

ASPINWALL, N. 1974. Genetic analysis of North American populations of the pink salmon, Oncorhynchus gorbuscha, possible evidence for the neutral mutation-random drift hypothesis. Evolution 28:295-305.

COCKLEY, D.E., J.L. GOOCH, and D.P. WESTON. 1977. Genic diversity in cave-dwelling crickets (Ceuthophilus gracilipes). Evolution 31:313-318.

GOOCH, J.L., and S.W. HETRICK. 1979. The relation of genetic structure to environmental structure: Gammarus minus in a karst area. Evolution 33:192-206.

GORMAN, G.C., M. SOULE, S.Y. YANG, and E. NEVO. 1975. Evolutionary genetics of insular Adriatic lizards. Evolution 29:52-71.

JOHNSON, M.S. 1971. Adaptive lactate dehydrogenase variation in the crested blenny, Anoplarchus. Heredity 27:205-226.

KOEHN, R.K. 1969. Esterase heterogeneity: Dynamics of a polymorphism. Science 163:943944.

NEI, M. 1972. Genetic distance between populations. Am. Nat., 106:283-292.

SCHOPF, T.J.M. 1973. Survey of genetic differentiation in a coastal zone invertebrate: the ectoproct Schizoporella errata. Biol. Bull. 145:78-87. 


\title{
Investigations of the Troglobitic Crayfish Orconectes inermis testii (Hay) in Mayfield's Cave, Monroe County, Indiana
}

\author{
H.H. Hobbs III*
}

\begin{abstract}
SUMMARY
Mark-recapture studies of some aspects of the biology of the cavernicolous crayfish, Orconectes inermis testii (Hay), were conducted from December, 1969 to March, 1970, in Mayfield's Cave, Monroe County, Indiana. Population size was estimated to be $66 \pm 9(95 \%$ C.L.) for the $300 \mathrm{~m}$ study area, but because of the small sample size, this is undoubtedly a deflated value. Size of animals, expressed as total length, indicates that the population was comprised primarily of adults. Seventy-four percent of the marked crayfish moved no more than $10.5 \mathrm{~m}$ away (total upstream and downstream distances) from the tagging site. Hence, this species appears to restrict its activities to a specific area ("home range") of up to $10.5 \mathrm{~m}$ of stream passage. Form I males traveled greater distances than did Form II (15.1 and $3.0 \mathrm{~m}$, respectively), possibly in search of mates. Adult females moved less than juveniles, and males appeared to move greater distances than females (means of 12.9 and $5.9 \mathrm{~m}$, respectively). Upstream movements were more commonly observed than downstream (mainly Form I males), indicating a possible restocking mechanism following floods. Distances traveled were not related to the size of individuals or to elapsed time.
\end{abstract}

\section{INTRODUCTION}

Packard (1888) made the earliest reference to Orconectes inermis testii (Hay) when he reported that C.H. Bollman had visited Mayfield's Cave, Monroe County, Indiana, and found "Cambarus pellucidus" in its stream. In 1891 Hay introduced the varietal name for the troglobitic crayfish in Mayfield's and Truett's caves. In 1907 Banta conducted an exhaustive study of the biota in Mayfield's Cave, and his observations concerning this subspecies are still heavily quoted. Hobbs et al. (1977) reported that this crayfish is currently known from 21 localities in "Monroe, Owen, and Greene (?) counties, Indiana. It intergrades with the typical subspecies [O. i. inermis Cope] in the more southern counties of the State".

A brief visit to Mayfield's Cave on 20 September 1969 convinced me that it would be an excellent site for a short-term study of the stream-dwelling $O$. i. testii. Not only was it conveniently located $(4.8 \mathrm{~km}$ west of Bloomington), but it was one of the few caves for which past faunal data were available. Thus, data collected 71 years after Banta's (1907) work could allow a comparative study, and perhaps enable an assessment of human impact on even a supposedly "isolated" environment.

* Department of Biology Wittenberg University Springfield, Ohio 45501 U.S.A. 
Studies were conducted from September 1969 to March 1970, but during March the owner of the cave, concerned with safety and his liability in the event of an accident, "closed" the cave.

\section{STUDY AREA}

The entrance to Mayfield's Cave is in the northeast side of an abandoned quarry about $4.8 \mathrm{~km}$ northwest of Bloomington, Indiana, Section 26, Township 9N, Range $1 W_{\text {SW } 1 / 4}$, NE 1/4, SW 1/4, at an elevation of $260 \mathrm{~m}$ (Fig. 1). The cave is developed in the Ste. Genevieve limestone and is approximately $550 \mathrm{~m}$ long. A stream flows from the rear and emerges at the surface as a small spring, approximately $230 \mathrm{~m}$ from the entrance. The stream passage is 4 to $6 \mathrm{~m}$ wide and 1 to $2 \mathrm{~m}$ high. Occasional areas near the entrance and rear have ceiling heights of approximately $4 \mathrm{~m}$. Small intermittent pools lie along the length of the stream (Fig. 1), which meanders along the passage and pe-

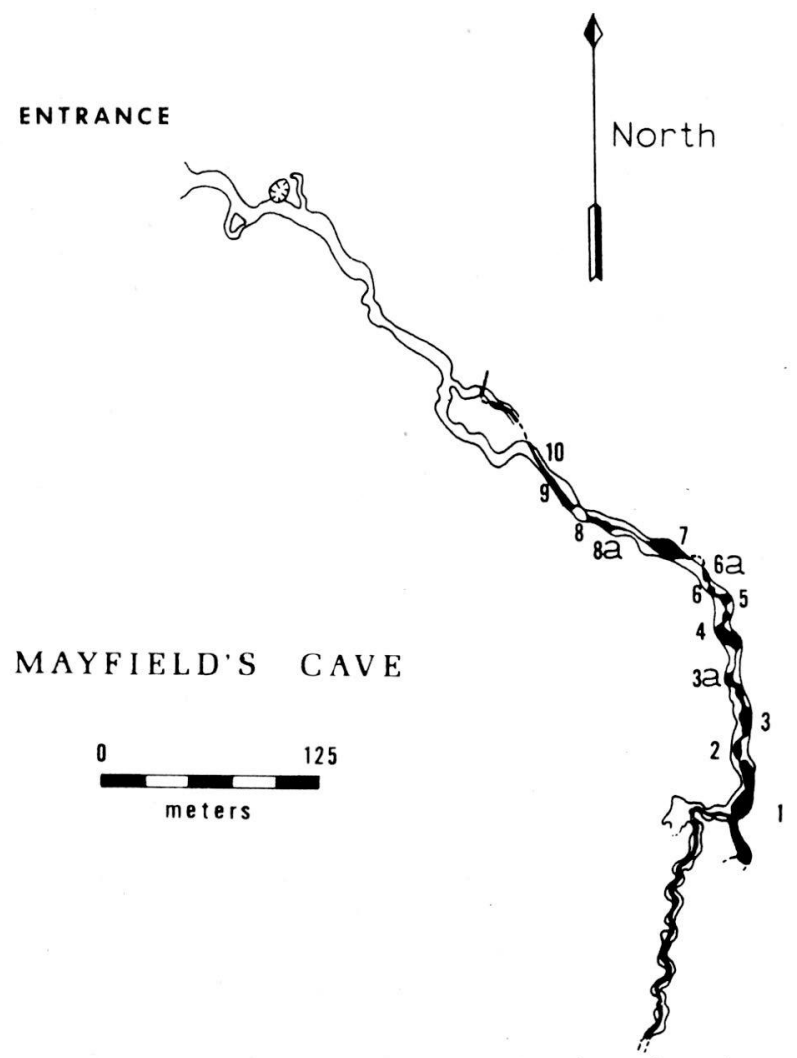

Fig. 1. Map of Mayfield's Cave showing the location of stations along the study area (after Banta, 1907: Plate 2). 
riodically undercuts the walls and disappears. The pooled areas range in depth from less than $1 \mathrm{~cm}$ to approximately $60 \mathrm{~cm}$ and are up to $9 \mathrm{~m}$ long and $2 \mathrm{~m}$ wide. The stream flows continually throughout all months of the year, although velocity is greatly reduced during summer and fall. Normally the water is clear, but becomes turbid as flow increases following precipitation. The substrate is variable, consisting of silt, sand, gravel, small rocks, and "breakdown."

Approximately $300 \mathrm{~m}$ of the stream passage was divided into stations, based primarily on the location of pools, to facilitate study (Fig. 1).

Two species of crayfishes, representing two genera, were sympatric in the stream. Orconectes inermis testii and Cambarus (Erebicambarus) laevis (Faxon). They occurred in all portions of the stream and were more often observed in pools than in shallow, faster flowing sections. Orconectes $i$. testii greatly exceeded $C$. (E.) laevis in numbers. Four species of entocytherid ostracods were present as commensals on the crayfishes: Sagittocythere barri (Hart and Hobbs), Donnaldsoncythere donnaldsonensis (Klie), Uncinocythere xania (Hart and Hobbs), and Dactylocythere susanae Hobbs III. Large numbers of the isopod Caecidotea stygius (Packard) and the amphipod Crangonyx gracilis Smith frequented primarily the pooled areas of the stream. Numerous Diptera, Coleoptera, plethodontid salamanders, and other taxa were observed throughout the cave (see Banta, 1907, for a detailed description of the cave, its fauna, and the environs at that time). One of the organisms reported by Banta to occur in the cave, Amblyopsis spelaea DeKay (Southern cavefish), has not been observed in recent years. Eigenmann introduced this species into the cave in the summer of 1901, and in 1907 Banta reported that it was abundant and "breeding freely." No cavefish occur naturally north of the East Fork of White River.

\section{METHODS}

Air and water temperatures were recorded on each visit to the cave. Records of surface air temperatures and precipitation for the period were obtained from a nearby weather station. Water levels, velocity, turbidity, relative abundance of organisms, and availabile food (leaves, detritus, dead organisms) were also noted at each station (Hobbs, 1973b). Crayfish were captured by hand or with the aid of a small net, marked, and released at the point of capture.

Various tagging methods were tested in the laboratory (Hobbs III, 1981), but work began before they had been evaluated. Crayfishes here were marked externally with blue and red Magic Marker as a temporary tag. The first crayfish was marked on 21 December 1969. The surface of the exoskeleton was dried and the appropriate station number marked on the dorsum of the carapace. Individuals were marked using combinations of the two colors on the telson, uropods, and abdominal segments (Fig. 2). Marking a crayfish and recording data took approximately five minutes per individual. The following information was recorded for each: sex (form in males; ovigerous, 


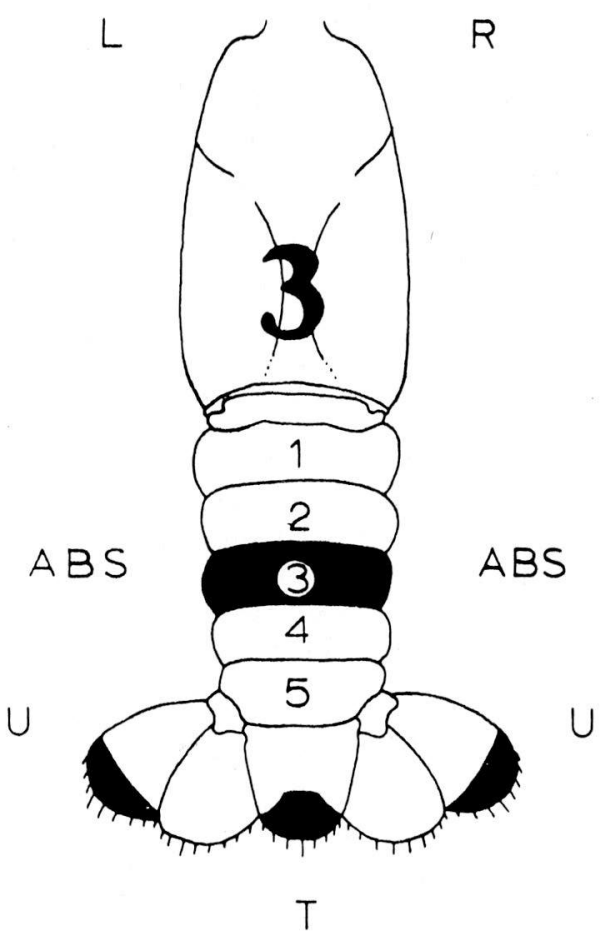

Fig. 2. Dorsal view of generalized crayfish, showing system of tagging individuals in Mayfield's Cave. Shown is individual R3UTU (3) ABS. R = color (red); 3 = station; $\mathrm{UTU}=$ uropods and telson; (3) $\mathrm{ABS}=3 \mathrm{rd}$ abdominal segment.

and with or without eggs or cement glands, in females), length (tip of rostrum to tip of telson), relative position in molt cycle, location where tagged, injuries and regenerated appendages, and responses to light. Total counts were made of all specimens observed on each trip. On occasion, crayfishes were removed from the cave and examined for symbionts.

The flexibility of the crayfish abdomen makes total length (TL) a less reliable absolute measurement than the more standard carapace length (CL). However, since TL was the datum obtained in the first two tagging efforts, and since exclusion of this information would have meant too great a loss, TL was retained as the expression of size throughout the study. Although the carapace and abdomen are approximately subequal in length in cambarid crayfishes, conversion of TL to CL involves potentially substantial error. 


\section{RESULTS}

Banta (1907) reported two species of crayfishes, $O$. i. testii (his $C$. pellucidus) and $C$. (E.) laevis (his $C$. bartonii), from this locality. Seventeen specimens of both species were observed on the first trip along the stream passage in 1969 , the majority of them $O$. $i$. testii.

Size: Forty-nine crayfishes were tagged from 21 December 1969 to 5 March 1970 (all captured specimens tagged). Orconectes $i$. testii was represented by $19 \mathrm{O}^{\circ} \mathrm{I}, 6 \mathrm{O}^{*} \mathrm{II}, 1{ }^{\circ} \mathrm{J}, 17 \%$, and $6 \% \mathrm{~J}$, suggesting that the population consisted mostly of adults $(86 \%)$, although several individuals less than $20 \mathrm{~mm}$ long were observed on two occasions in January 1970. Males ranged in total length from 27 to $58 \mathrm{~mm}$ and females from 20 to $61 \mathrm{~mm}$, with individuals of each sex evenly distributed over its size range.

Temperature: Only slight variations in temperature within the cave occurred during the study. Observed extremes for water temperature were 11.1 and $13.1^{\circ} \mathrm{C}$, and 11.7 and $13.2^{\circ} \mathrm{C}$ for air temperature.

Numbers (or population size): of the 49 crayfishes (O. i. testii) tagged and released, 23 were recovered at least once, resulting in a $47 \%$ recovery rate. The greatest number of recaptures for any individual was four, and that for only one crayfish. Hobbs (1973a) reported the population in the cave to be $128 \pm 33(95 \%$ C.L. $)$ in the $300 \mathrm{~m}$ study area. Further analysis of data and use of the Schumacher-Eschmeyer Index (Schumacher and Eschmeyer, 1943) yielded the more accurate figure of $66 \pm 8.9$ (95\% C.L.), or two crayfish per $10 \mathrm{~m}$ of stream passage.

Movements: Natural movements of 23 individuals of $O$. $i$. testii are given in Table 1. All individuals recaptured at least once are included. Some of the apparently short distances recorded $(0.3$ and $0.6 \mathrm{~m})$ occurred 60 and 56 days, respectively, between recaptures. This does not imply that these individuals did not move greater distances. Some of the greater movements recorded $(35$ and $42 \mathrm{~m}$ ) also occurred over short periods of time (1 and 20 days, respectively). The minimum and maximum distances that individuals moved from the point of marking lie between 0 and $42 \mathrm{~m}$. Although, no crayfish were recorded as moving 0 meters, some individuals were subsequently observed in the same location within a small area of stream passage.

The time elapsed between markings and recaptures varied considerably (Fig. 3), and this and the distances traveled on any one occasion impose constraints on interpreting these data. Consequently, the range of distances moved between recaptures, regardless of direction, was divided into quartiles: $0-10.5 \mathrm{~m}$ (Quartile 1 $\left.=\mathrm{Q}_{1}\right), 10.5-21.0 \mathrm{~m}\left(\mathrm{Q}_{2}\right), 21.0-32.3 \mathrm{~m}\left(\mathrm{Q}_{3}\right)$, and $32.3-42.0 \mathrm{~m}\left(\mathrm{Q}_{4}\right)$. For $O$. i. testii, $80.4 \%$ of the total movements

$$
\left(\frac{\not \text { of movements within } \mathrm{O}-10.5 \mathrm{~m} \text { between recaptures }-\mathrm{Q}_{1}}{\text { Total } \not \neq \text { of movements }}\right)
$$

fell within $\mathrm{Q}_{1}, 7.8 \%$ in $\mathrm{Q}_{2}, 2.0 \%$ in $\mathrm{Q}_{3}$, and 9.8\% in $\mathrm{Q}_{4}$. The large percentage of $Q_{1}$ movements suggests that individuals of this species tend to restrict their 


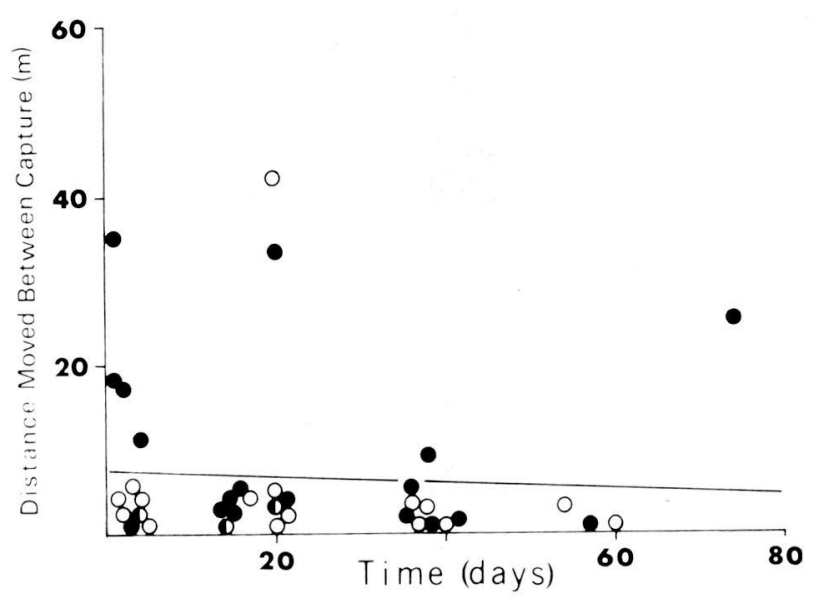

Fig. 3. Plot of distances moved by $O$. i. testii as a function of time (days). Gpen circle $=९$, closed circle $=\propto \mathrm{I}$, half-filled circle $=\propto \mathrm{II}$.

activity to a specific area, probably somewhere between 0 and $10.5 \mathrm{~m}$ (Fig. 4, 5).

For $O$. $i$. testii, $74 \%$ of the individuals

$$
\text { ( } \frac{\not \text { of individuals moved } 0-10.5 \mathrm{~m} \text { total range of movements }}{\text { Total } \nLeftarrow \text { of individuals }} \text { ) }
$$

moved no more than $10.5 \mathrm{~m}$ away from their original marking site, $8.7 \%$ moved 10.5 to $21.0 \mathrm{~m}, 4.4 \%$ moved from 21.0 to $32.2 \mathrm{~m}$, and $13.0 \%$ moved from 32.3 to $42.0 \mathrm{~m}$. The percentages are based on the total range of movements (distance traveled between maximum upstream and downstream positions).

Upstream movements seem to dominate over downstream in $O$. i. testii (mainly Form I males) in this cave (Table 1, Fig. 6). Fifteen individuals (65\%) moved upstream and $8(35 \%)$ downstream, based on their final position relative to the location where marked.

The movements of two crayfishes are noteworthy. Individual 3E of $O, i$. testii (a Form I male) moved upstream $35.4 \mathrm{~m}$ in a 24 -hour period. This compares with an individual of $O$. juvenilis (Hagen) reported by Merkle (1967) that moved at least $95.6 \mathrm{~m}$ in 48 hours. Individual $6 \mathrm{~A}$ of $O$. $i$. testii (also a Form I male) was recovered 4 January at station 6 . Two days later it was found at station $5,17.1 \mathrm{~m}$ upstream. To get here it had to travel at least 8.9 $\mathrm{m}$ out of the water over gravel and stone, as the stream was at low level and pools 5 and 6 were not connected. Additional data concerning the biology of this species may be found in Hobbs $(1972,1975 a, b)$. 


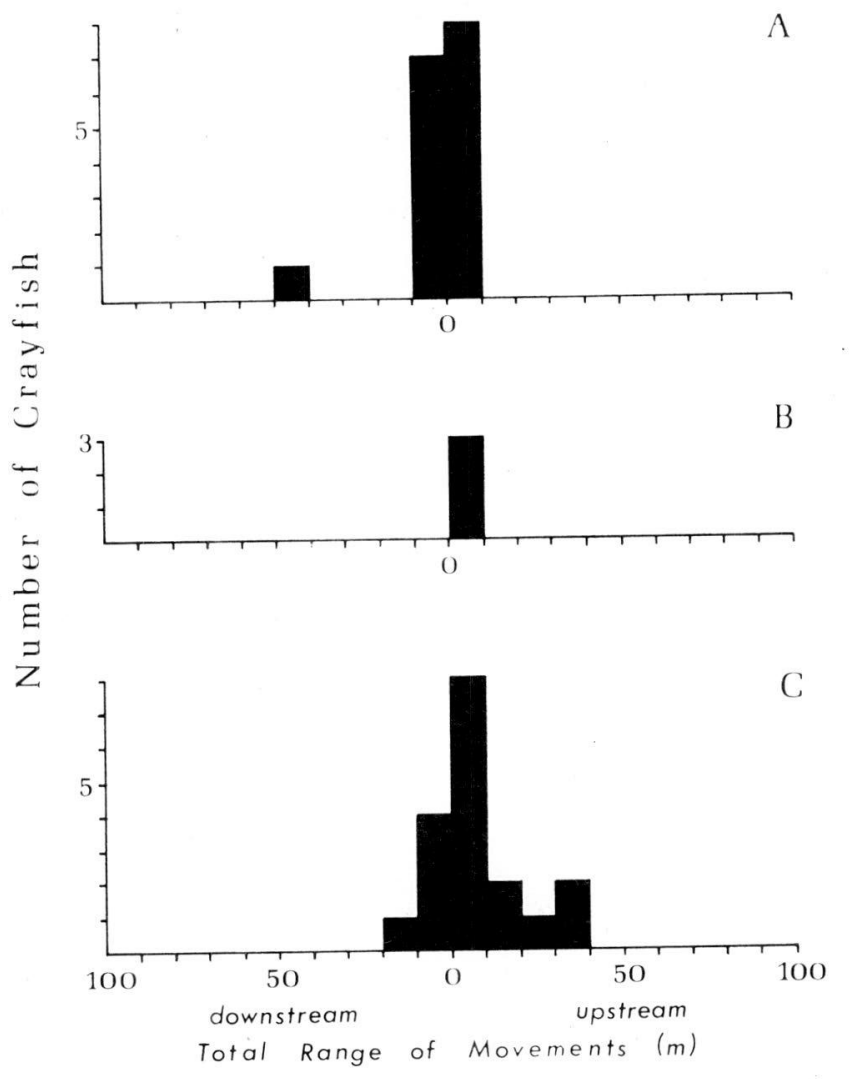

Fig. 4. Histogram of distances and directions moved by tagged $O$. $i$. testii between captures. A. females; B. Form II males; C. Form I males.

\section{DISCUSSION AND CONCLUSIONS}

During the seven-month study period the subterranean water and air temperatures were very stable, varying only a maximum of 2.5 and $2.6^{\circ} \mathrm{C}$, respectively. Variations as small as these are common in caves. The noticeable drop in water.temperature during the month of March is attributed to snow and ice melt.

Twenty-three marked $O . i$. testii crayfish were recovered at least once for a $47 \%$ recapture rate. This percentage is relatively high when compared with most other studies: Camougis and Hichar (1959) reported only $12.5 \%$ recovery, Black (1963) $17.5 \%$, Momot (1966) about 25\%, and Mobberly and Pfrimmer (1967) better than $19 \%$ recovery for both males and females. Merkle 


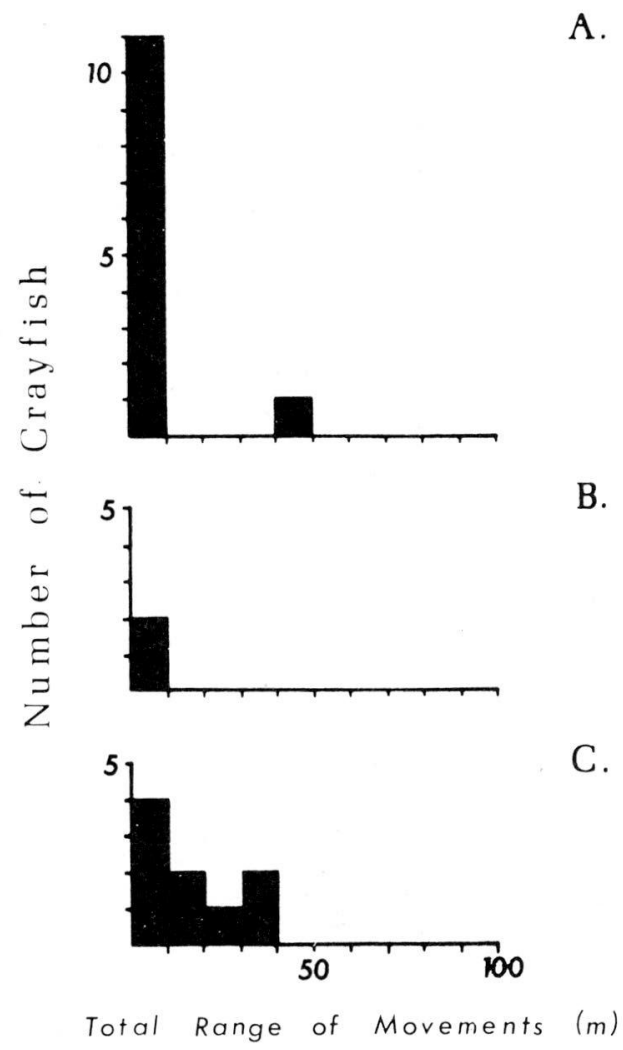

Fig. 5. Histogram of the total range of movements (distance between farthest upstream and downstream positions) of tagged $O$. i. testii. A. females, B. Form II males, C. Form I males.

(1967), however, reported $47.1 \%$ total recovery in her study of Orconectes juvenilis. An estimate of $O$. $i$. testii population size in the $300 \mathrm{~m}$ study area was determined to be $66 \pm 8.9$ (95\% C.L.). The size of the specimens indicates that the population was comprised primarily of adults.

Since $74 \%$ of $O$. $i$. testii moved no more than $10.5 \mathrm{~m}$ away (total upstream and downstream distance) from the tagging site, this species apparently tends to restrict its activities to a specific area (home range) of up to $10.5 \mathrm{~m}$. Form I males traveled greater distances than did Form II, possibly in search of mates. Adult females showed less movement than juveniles, and males appeared to move greater distances than females, means of 12.9 and $5.9 \mathrm{~m}$, respectively. Upstream movements were predominate (mainly Form I males), indicating a possible restocking mechanism following floods. These 
Table 1. Recapture data for $O$. $i$. testii in Mayfield's Cave. $\mathrm{I}=$ individual, $\mathrm{L}=$ lenght, $\mathrm{S}=$ station number, $\mathrm{DM}=$ date marked, $\mathrm{T}=$ time (days) elapsed since last capture, $\mathrm{D}=$ distance $(\mathrm{m})$ and direction moved since last capture $(\mathrm{d}=$ downstream, $\mathrm{u}=\mathrm{upstream})$, TT $=$ time elapsed $($ days $)$ from marking, $\mathrm{FP}=$ final position relative to marking, $\mathrm{TR}=$ total range $(\mathrm{m})$ of movement.

RECAPTURE

\begin{tabular}{|c|c|c|c|c|c|c|c|c|c|c|c|c|c|c|c|c|c|c|c|}
\hline \multirow[t]{2}{*}{ I } & \multirow[t]{2}{*}{ SEX } & \multicolumn{3}{|c|}{ MARKED } & \multicolumn{3}{|c|}{1} & \multicolumn{3}{|c|}{2} & \multicolumn{3}{|c|}{3} & \multicolumn{3}{|c|}{4} & \multirow[b]{2}{*}{ TT } & \multirow[b]{2}{*}{ FP } & \multirow[b]{2}{*}{ TR } \\
\hline & & $\mathbf{L}$ & $\mathbf{S}$ & DM & $\mathbf{S}$ & $\mathbf{T}$ & D & $\mathbf{S}$ & $\mathbf{T}$ & D & $\mathbf{S}$ & $\mathbf{T}$ & D & $\mathbf{S}$ & $\mathbf{T}$ & D & & & \\
\hline IB & $\sigma^{\circ} \mathrm{I}$ & 45 & 1 & $21 / 12 / 69$ & 1 & 14 & $3 d$ & 1 & 4 & $11 \mathrm{u}$ & 1 & 36 & $5 \mathrm{~d}$ & 1 & 20 & $4 u$ & 74 & $6 u$ & 11 \\
\hline $1 \mathrm{C}$ & 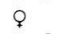 & 44 & 1 & $21 / 12 / 69$ & 1 & 17 & $4 \mathrm{~d}$ & & & & & & & & & & 17 & $4 \mathrm{~d}$ & 4 \\
\hline $1 \mathrm{E}$ & $\subsetneq \mathbf{J}$ & 20 & 1 & $4 / 1 / 70$ & 1 & 4 & $3 d$ & 1 & 36 & $3 \mathrm{u}$ & 3 & 20 & $42 \mathrm{~d}$ & & & & 60 & $42 \mathrm{~d}$ & 42 \\
\hline $1 \mathrm{~F}$ & ○ J & 22 & 1 & $4 / 1 / 70$ & 1 & 4 & $2 d$ & & & & & & & & & & 4 & $2 d$ & 2 \\
\hline $1 \mathrm{~J}$ & $\mathbf{J}$ & 22 & 1 & $6 / 1 / 70$ & 1 & 1 & $4 u$ & & & & & & & & & & 1 & $4 u$ & 4 \\
\hline $1 \mathrm{M}$ & $0^{*} \mathrm{I}$ & 43 & 1 & $7 / 1 / 70$ & 1 & 37 & $0.9 \mathrm{~d}$ & & & & & & & & & & 37 & $0.9 \mathrm{~d}$ & 0.9 \\
\hline 10 & $\sigma^{\circ} \mathrm{I}$ & 50 & 1 & $8 / 1 / 70$ & 1 & 56 & $0.6 \mathrm{u}$ & & & & & & & & & & 56 & $0.6 \mathrm{u}$ & 0.6 \\
\hline $1 \mathrm{Q}$ & $\uparrow$ & 55 & 1 & $13 / 2 / 70$ & 1 & 20 & $2 \mathrm{u}$ & & & & & & & & & & 20 & $2 \mathrm{u}$ & 2 \\
\hline $2 \mathrm{~B}$ & $\subsetneq \mathbf{J}$ & 30 & 2 & $4 / 1 / 70$ & 2 & 4 & $5 \mathrm{~d}$ & & & & & & & & & & 4 & $5 \mathrm{~d}$ & 5 \\
\hline $2 \mathrm{D}$ & O* II & 44 & 2 & $13 / 2 / 70$ & 2 & 20 & $3 u$ & & & & & & & & & & 20 & $3 \mathrm{~d}$ & 5 \\
\hline $3 \mathrm{~A}$ & $O^{*} \mathrm{I}$ & 58 & 3 & $21 / 12 / 69$ & 3 & 16 & $4 d$ & 3 & 38 & $9 \mathrm{u}$ & & & & & & & 54 & $5 u$ & 9 \\
\hline $3 \mathrm{~B}$ & o I & 41 & 3 & $21 / 12 / 69$ & 2 & 74 & $25 \mathrm{u}$ & & & & & & & & & & 74 & $25 u$ & 25 \\
\hline $3 C$ & Q & 38 & 3 & $21 / 12 / 69$ & 3 & 54 & $3 d$ & & & & & & & & & & 54 & $3 \mathrm{~d}$ & 3 \\
\hline $3 \mathrm{E}$ & $0 \mathrm{I}$ & 43 & 3 & $6 / 1 / 70$ & 1 & 1 & $35 \mathrm{~d}$ & & & & & & & & & & 1 & $35 u$ & 35 \\
\hline $5 \mathrm{~A}$ & O. II & 35 & 5 & $21 / 12 / 69$ & 5 & 14 & lu & 5 & 2 & $2 u$ & & & & & & & 16 & $3 u$ & 3 \\
\hline $6 \mathrm{~A}$ & $O^{*} \mathrm{I}$ & 40 & 6 & $21 / 12 / 69$ & 6 & 14 & $1 \mathrm{u}$ & 5 & 2 & $17 \mathrm{u}$ & 6 & 1 & $18 \mathrm{~d}$ & & & & 17 & 0 & 18 \\
\hline $7 \mathrm{~B}$ & O I & 41 & 7 & $21 / 12 / 69$ & 7 & 14 & $2 u$ & 7 & 3 & $0.3 \mathrm{u}$ & 7 & 37 & $0.3 \mathrm{u}$ & & & & 54 & $3 u$ & 2.6 \\
\hline $7 \mathrm{C}$ & Q & 37 & 7 & $6 / 1 / 70$ & 7 & 1 & $2 \mathrm{u}$ & 7 & 37 & $0.6 \mathrm{~d}$ & & & & & & & 38 & lu & 1.4 \\
\hline $8 \mathrm{~A}$ & $0 \mathrm{I}$ & 47 & 8 & $4 / 1 / 70$ & 8 & 40 & lu & 7 & 20 & $33 u$ & & & & & & & 60 & $34 u$ & 0.3 \\
\hline $8 \mathrm{~B}$ & १ & 38 & 8 & $4 / 1 / 70$ & 8 & 60 & $0.3 \mathrm{u}$ & & & & & & & & & & 60 & $0.3 \mathrm{u}$ & 0.3 \\
\hline $8 \mathrm{aA}$ & $\uparrow$ & 61 & $8 a$ & $13 / 2 / 70$ & $8 a$ & 20 & $0.6 \mathrm{u}$ & & & & & & & & & & 20 & $0.6 \mathrm{u}$ & 0.6 \\
\hline $10 \mathrm{C}$ & $\oint^{+} \mathbf{J}$ & 22 & 10 & $6 / 1 / 70$ & 10 & 38 & $3 u$ & & & & & & & & & & 38 & $3 u$ & 3 \\
\hline 10D & @ & 55 & 10 & $4 / 1 / 70$ & 10 & 40 & $1 \mathrm{u}$ & 9 & 20 & $4 d$ & & & & & & & 60 & $3 \mathrm{~d}$ & 4 \\
\hline
\end{tabular}




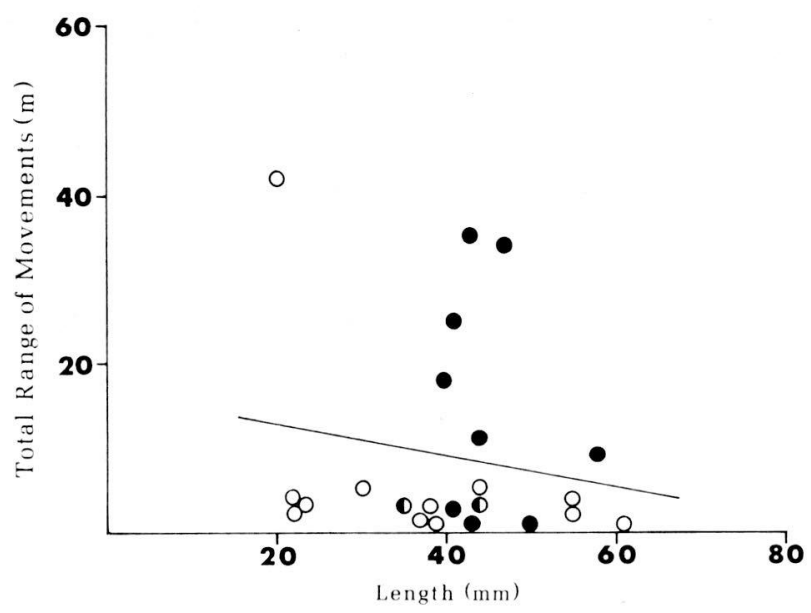

Fig. 6. Plot of total range of movements (m) of O. i. testii as a function of total length (mm). Open circle $=\varnothing$, closed circle $=\sigma^{\circ} \mathrm{I}$, half-filled circle $=\sigma^{\circ} \mathrm{II}$.

data partially support those of Minckley (1964), Momot (1966), and Elliott (1971) that certain aquatic invertebrates exhibit extensive upstream movement, although not necessarily as a compensatory movement for downstream displacement following floods. Although some flooding occurred during the study period (rains did affect and increase the volume of flow through the stream passage), no major spates took place. No evidence from this study supports the proposal of Momot (1966) and Waters (1961) that flooding results primarily in downstream displacement. This undoubtedly occurs to some degree during heavy flow. It is difficult to postulate reasons for the net upstream movements without some data concerning the environment (i.e., food availability and fluctuation, water chemistry, flooding) and further information on the animals (e.g., reproductive cycles).

If total range of movements is compared with size, it is apparent that smaller crayfish have a larger "home range" than do adults (Fig. 6). However, the size of this range for $O$. $i$. testii in Mayfield's Cave is not related to animal size, per se, but does seem to be related to sex and stage of reproduction. Using the values of total range of movements upstream and downstream (Fig. 5), it is clear that Form I males are more active and travel greater distances than do Form II males (means 15.1 and $3.0 \mathrm{~m}$ total range of movements, respectively), and also seem to move upstream more than downstream. Form I males are in breeding state and probably travel greater distances in search of mates than do Form II males. The latter most likely move in search for food, during intraspecific interactions, or to escape predation. Comparing the movements of all males and females, those of males $(12.9 \mathrm{~m})$ 
are greater than those of females $(5.9 \mathrm{~m})$. The distances traveled are not directly dependent on the time elapsed, and hence time was not an important factor (Fig. 3).

\section{RÉSUMÉ}

Certains aspects de la biologie de l'écrevisse cavernicole Orconectes inermis testii (Hay) ont été étudiés par la méthode de marquage et de recapture, entre décembre 1969 et mars 1970, à la grotte de Mayfield, Comté de Monroe, Indiana. L'effectif de la population a été estimé à $66 \pm 9$ (probabilité de $95 \%$ ), pour les 300 mètres du cours d'eau étudié, mais par suite du faible nombre d'individus échantillonnés, cet effectif est sans doute sous-estimé. La taille des animaux, exprimée par leur longueur totale, indique que la population est composée essentiellement d'adultes. Soixante quatorze pour cent des écrevisses marquées ne se sont pas déplacées au delà de 10,5 mètres (total des distances vers l'amont et vers l'aval) à partir du site de marquage. Ainsi, cette espèce semble limiter ses activités à une aire restreinte ("home range") qui ne dépasse pas une longueur de 10,5 mètres du cours de la rivière. Les mâles de la forme I se déplacent à de plus grandes distances que ceux de la forme II (respectivement 15,1 et 3,0 mètres), vraisemblablement en quête d'accouplement. Les femelles adultes se déplacent moins que les juvéniles, tandis que les mâles semblent se déplacer plus loin que les femelles (moyennes respectives de 12,9 et 5,9 mètres). Des déplacements vers l'amont furent observés plus fréquemment que vers l'aval, indiquant la possibilité d'existence d'un mécanisme de repeuplement compensant les dérives dues aux crues. Les distances de déplacement n'ont paru fonction, ni de la taille des individus, ni du temps écoulé.

\section{LITERATURE}

BANTA, A.M. 1907. The fauna of Mayfield's Cave. Carnegie Inst. Wash. Publ. 67:1-114.

BLACK, J.E. 1963. Obsevations on the home range of stream-dwelling crawfishes. Ecology 44:592-595.

CAMOUGIS, G., and J.K. HICHAR 1959. Some stues on crayfish distribution in a small pond. Am. Midl. Nat. 62:227-231.

ELLIOTT, J.M. 1971. Upstream movements of benthic invertebrates in a Lake District stream. J. Anim. Ecol. 40:235-252.

HAY, W.P. 1891. Two new subterranean crustaceans from the United States. Proc. Biol. Soc. Washington 14:179-180.

HOBBS, H.H., Jr., H.H. HOBBS III, and M.A. Daniel. 1977. A review of the troglobotic decapod crustaceans of the Americas. Smithson. Contrib. Zool. 244:1-183.

HOBBS, H.H., III, 1972. The distribution and population dynamics of the cave crayfishes of southern Indiana. 14th Annu. Rep. Cave Res. Found. 37-41.

HOBBS, H.H. III, 1973a. Movement and ecology of troglobitic crayfishes from southern Indiana caves. NSS '73 Prog. (30th Ann. Conv.), 16-17.

HOBBS, H.H., III, 1973b. The population dynamics of cave crayfishes and their commensal ostracods from southern Indiana. Ph. D. Dissertation, Department of Zoology, Indiana University, Bloomington.

HOBBS, H.H., III, 1975a. Observations on the cave-dwelling crayfishes of Indiana. Proc. 2nd Int. Crayfish Symp., Louisiana State Univ., 405-414.

HOBBS, H.H., III, 1975b. Distribution of Indiana cavernicolous crayfishes and their ectocommensal ostracods. Int. J. Speleol. 7:273-302.

HOBBS, H.H., III. 1981. Studies of the cave crayfish, Orconectes inermis inermis Cope (Decapoda, Cambaridae). Part IV: Mark-recapture procedures for estimating population size and movements of individuals. Int. J. Speleol 10:303-322.

MERKLE, E.L. 1967. The home range and homing ability of the crayfish Orconectes juvenalis in a permanent Kentucky stream. M.S. Thesis, Univ. Kentucky, Lexington.

MINCKLEY, W.L. 1964. Upstream movements of Gammarus (Amphipoda) in Doe Run, Meade County, Kentucky. Ecology 45:195-197. 
MOBBERLY, W.C., Jr., and R. PFRIMMER. 1967. Distribution of crayfish in a roadside ditch. Am. Midl. Nat. 70:82-88.

MOMOT, W.T. 1966. Upstream movement of crayfish in an intermittent Oklahoma stream. Am. Midl. Nat. 75:150-159.

PACKARD, A.S. 1888. The cave fauna of North America with remarks on the anatomy of the brain and origin of the blind species. Mem. Nat. Acad. Sci. 4:1-156.

SCHUMACHER, F.X., and R.W. ESCHMEYER. 1943. The estimation of fish population in lakes or ponds. J. Tenn. Acad. Sci. 18:228-249.

WATERS, T. 1961. Standing crop and drift of stream bottom organism. Ecology 42:532-537. 


\title{
Variation among Populations of the Troglobitic Amphipod Crustacean Crangonyx antennatus Packard (Crangonyctidae) \\ Living in Different Habitats, III: Population Dynamics and Stability
}

\author{
Gary W. Dickson* \\ and \\ John R. Holsinger**
}

\begin{abstract}
SUMMARY
Populations of the troglobitic amphipod Crangonyx antennatus from caves in Lee Co., Virginia (U.S.A.) were investigated on both a short and long term basis. The dynamics of populations living in two distinct aquatic cave habitats (mud-bottom pools and gravel-bottom streams) were compared seasonally for one year. Sex ratios indicated a larger number of females in both pool and stream habitats. The majority of males in both habitats were found to be sexually mature throughout the year investigated. Seasonal fluctuations in female maturity were observed in both habitats, with larger numbers collected in June and August. In addition, a larger number of ovigerous females were observed in the spring, indicating the possibility of a circannian reproductive cycle in both pools and streams. The structure of populations from the caves studied appears to reflect a controlled recruitment of females from immature to mature stages. In order to determine the stability of population structure, collection data from a pool and a stream habitat for a 10-year period were analyzed. Population structures were found to be relatively stable over long periods in both habitats, with immature females comprising the dominant population class.
\end{abstract}

\section{INTRODUCTION}

The population structure and dynamics of troglobitic species (i.e., obligatory cavernicoles) have been of interest because of the unique characteristics of the cave environment. These include the relative constancy of physical and chemical parameters and the lack of major food sources. In general, troglobitic species exhibit K-selected population characteristics (MacArthur and Wilson, 1967), including small population size, late maturity, low reproductive rates, large size at hatching, and increased longevity. K-selected properties have previously been reported in populations of aquatic troglobites, inclu-

* Health and Environmental Review Division, Office of Toxic Substances, Environmental Protection Agency - Washington, D.C. 20460, U.S.A. .

** Department of Biological Sciences, Old Dominion University - Norfolk, Virginia 23508 U.S.A. . 
ding fish (Heuts, 1951; Poulson, 1963), crayfish (Hobbs, 1973; Cooper, 1975; Cooper and Cooper, 1976, 1978; Franz, 1978), shrimp (Cooper, 1975; Cooper and Cooper, 1974), amphipods (Ginet, 1960; Holsinger and Holsinger, 1971), isopods (Magniez, 1975; Henry, 1976), and gastropods (Turner and Clench, 1974). An excellent review of earlier literature dealing with this subject is presented in Vandel (1965).

In the present study, population dynamics and stability were investigated in the troglobitic amphipod Crangonyx antennatus. This widespread species inhabits two distinct types of cave habitats (mud-bottom pools and gravel bottom streams) in the southern Appalachians of the eastern United States (Holsinger, 1969, 1972). Crangonyx antennatus has been found to exhibit both morphological and behavioral differences associated with these habitat types (Dickson, 1977a, 1977b). The presence of this species in two habitats offers a unique opportunity to study the dynamics and stability of a troglobitic species under different selective pressures.

The present investigation was conducted to: (1) determine the structure and dynamics of $C$. antennatus populations over a seasonal cycle, (2) compare population characteristics between stream and pool habitats, and (3) examine the stability of population structure over a relatively long period.

\section{METHODS AND MATERIALS}

Populations of $C$. antennatus were sampled seasonally from six caves in Lee Co., Virginia, during 1974 and 1975. Crangonyx antennatus populations are relatively large in this area, allowing selective sampling without disturbing population stability. Three of the populations sampled inhabited mudbottom pools (Roadside No. 1, Molly Wagle, and Sweet Potato caves) and three inhabited gravel-bottom streams (Spangler, Cope, and Gallohan No. 2 caves). In general, mud-bottom pool habitats contained greater quantities of available food, fewer predators, and smaller numbers of potential competitors than stream habitats. A complete ecological description of these aquatic habitats has been reported elsewhere (Dickson and Kirk, 1976; Dickson, 1977a).

Ten sample sites of $0.09 \mathrm{~m}^{2}$ were randomly selected in stream and pool areas of each cave during four seasonal sampling periods. All $C$. antennatus observed within the sampling sites, including any present in the top $5 \mathrm{~cm}$ of gravel in the stream habitats, were collected until 25 amphipods were obtained from each cave. Amphipods were preserved in $70 \%$ ethyl alcohol for later examination in the laboratory.

Each amphipod was examined to determine sex and life stage. Based on previous observations of this species, amphipods under $4.0 \mathrm{~mm}$ in body length (base of first antennate to base of telson) were considered juveniles. Males were distinguished by a pair of papillae on the sternum of the last thoracic segment, while females were distinguished by oostegites (brood plates) at the base of the second through fifth pereopods. Sexually mature males were recognized by the presence of calceoli (small, paddle-shaped structures) on 
the second antennae. Mature females possess long marginal setae on the margins of the oostegites. In addition, eggs contained within the brood pouch of females were counted and measured.

In conjunction with the population information gained from preserved material, live $C$. antennatus from both pool (Molly Wagle Cave) and stream (Spangler Cave) habitats were transported to the laboratory for study. Amphipods were kept in an environmental chamber under simulated cave conditions (i.e., $10^{\circ} \mathrm{C}$ in complete darkness). Pool-dwelling amphipods were placed in cultures containing mud sediments collected from their original habitat; stream-dwelling amphipods were reared with cave stream gravel and autumn shed leaves. Culture dishes were filled to a depth of $2 \mathrm{~cm}$ with spring water collected near the original habitats.

The long term stability of $C$. antennatus population structure was determined through examination of collection data acquired over a 10 -year period from 1965 to 1975. Crangonyx antennatus populations were sampled sporadically during this period in both a pool habitat cave (Molly Wagle Cave, 13 visits) and a stream habitat cave (Spangler Cave, six visits). The sex and life stage of amphipods from these collections were tabulated.

\section{RESULTS}

Male/Female Sex Ratios. In general, fewer males were found in C. antennatus populations in both habitats during the year studied (Fig. 1). Fluctuations were observed in this ratio seasonally, although no patterns appear present. No significant differences were observed in sex ratios between populations living in pool and stream habitats (Table 1).

To contrast cave and epigean amphipods of the genus Crangonyx, male/female sex ratios obtained by Sprules (1967) for the epigean amphipod C.richmondensis laurentianus were compared to sex ratios obtained for $C$. antennatus from pool and stream habitat caves. No differences were observed between the epigean and troglobitic Crangonyx species (Table 1).

A comparison of sex ratios was also made between $C$. antennatus and three troglobitic species of the genus Stygobromus (S. emarginatus, S. russelli and $S$. spinatus), which have previously been noted for their differential sex ratios favoring females (Culver and Holsinger, 1969; Holsinger, 1978). Significant differences $(\mathrm{P}<0.01)$ were found between sex ratios from both habitats and the Stygobromus values (Table 1).

Sexual Maturity. Crangonyx antennatus populations in both stream and pool habitats are characterized by a very high percentage of males which are sexually mature (Fig. 2). In contrast, the percentage of sexually mature females was relatively low. No significant differences $(P>0.05)$ were observed between lotic and lentic populations in the percentage of sexually mature males or females (Fig. 2, Table 2). In four of the six caves studied, increases in the number of mature females were observed in the June collection (Fig. 2).

Ovigerous Females and Juveniles. Both stream and pool habitats contained few ovigerous females, with greater numbers observed during February 
Galkhan 2

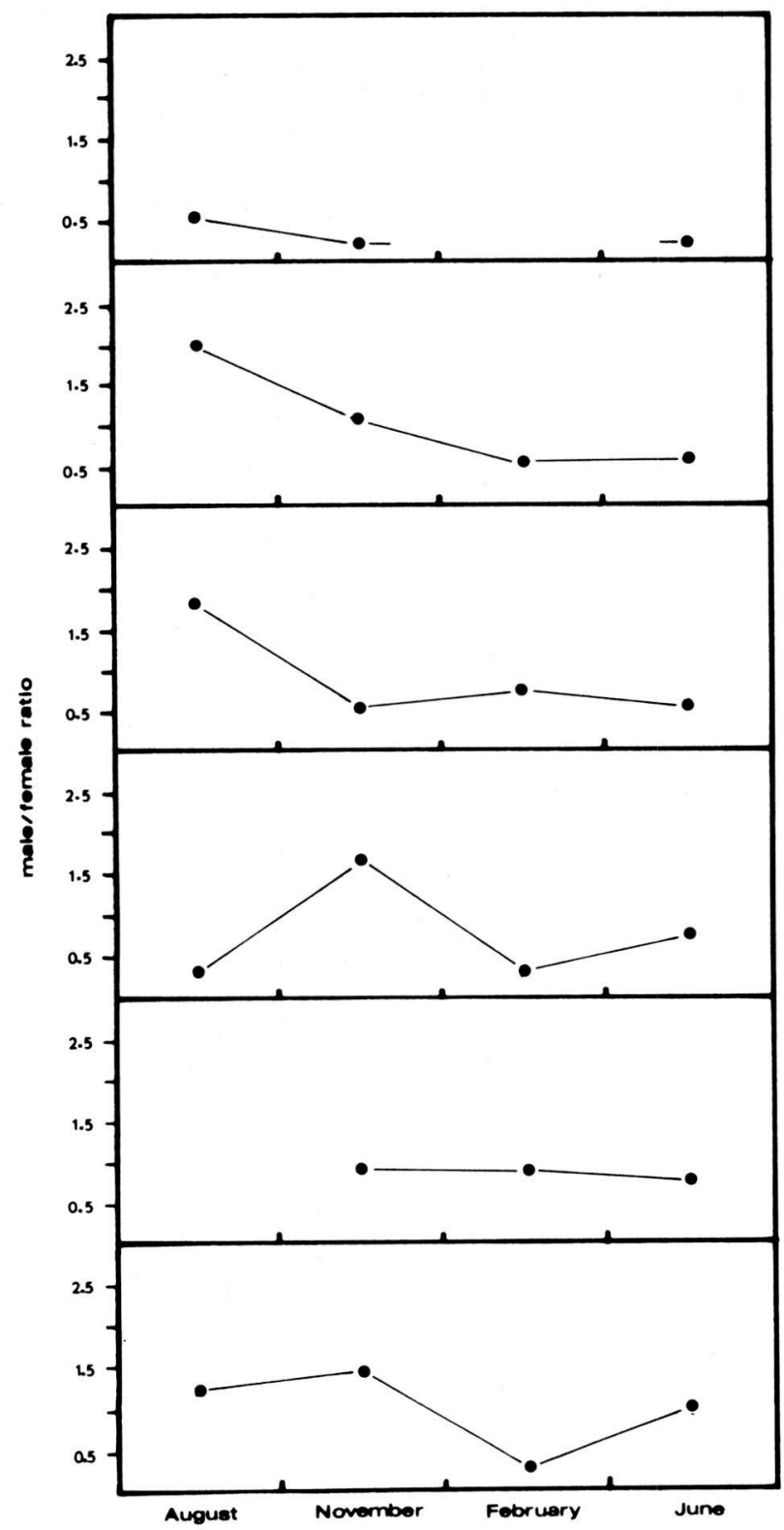

Spangler

Cope

Sweet Potato

Molly Wagle

Roadside I

Fig. 1. Male/female sex ratios of populations of $C$. antennatus sampled from each cave during seasonal collection periods. Due to adverse conditions, sampling could not be conducted in Molly Wagle Cave in August and Gallohan No. 2 Cave in February. 
Table 1. Comparison of Crangonyx antennatus sex ratios between habitats and with other epigean and troglobitic amphipod species. Crangonyx richmondensis sex ratios are from collections in a Canadian lake, whereas Stygobromus values are the average sex ratio of three troglobitic species: Stygobromus emarginatus, Stygobromus russelli, and Stygobromus spinatus. Significance is determined by the use of the MannWhitney U test.

\begin{tabular}{|c|c|c|c|c|}
\hline & $\begin{array}{l}\text { C. antennatus } \\
\text { Pool habitat }\end{array}$ & $\begin{array}{l}\text { C. antennatus } \\
\text { Stream habitat }\end{array}$ & C. richmondensis ${ }^{*}$ & $\begin{array}{r}\text { Stygobromus } \\
\text { species }\end{array}$ \\
\hline $\begin{array}{l}\text { C. antennatus } \\
\text { Pool habitat }\end{array}$ & 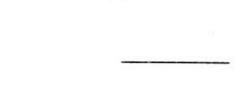 & $\begin{array}{r}\text { N.S. }(P>0.05) \\
U_{\mathrm{s}}=74.5\end{array}$ & $\begin{array}{r}\text { N.S. }(P>0.05) \\
U_{\mathrm{s}}=36\end{array}$ & $\begin{array}{r}\text { Sig. }(P<0.01) \\
U_{\mathrm{s}}=118\end{array}$ \\
\hline $\begin{array}{l}C \text {. antennatus } \\
\text { Stream habitat }\end{array}$ & $\begin{array}{r}\text { N.S. }(P>0.05) \\
U_{s}=74.5\end{array}$ & - & $\begin{array}{r}\text { N.S. }(P>0.05) \\
U_{s}=27\end{array}$ & $\begin{array}{c}\text { Sig. }(P<0.01) \\
U_{\mathrm{s}}=118\end{array}$ \\
\hline
\end{tabular}

* Sprules, 1967.

** Culver and Holsinger, 1969; Holsinger, 1978. 


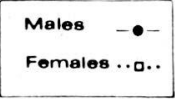

Gallohan 2

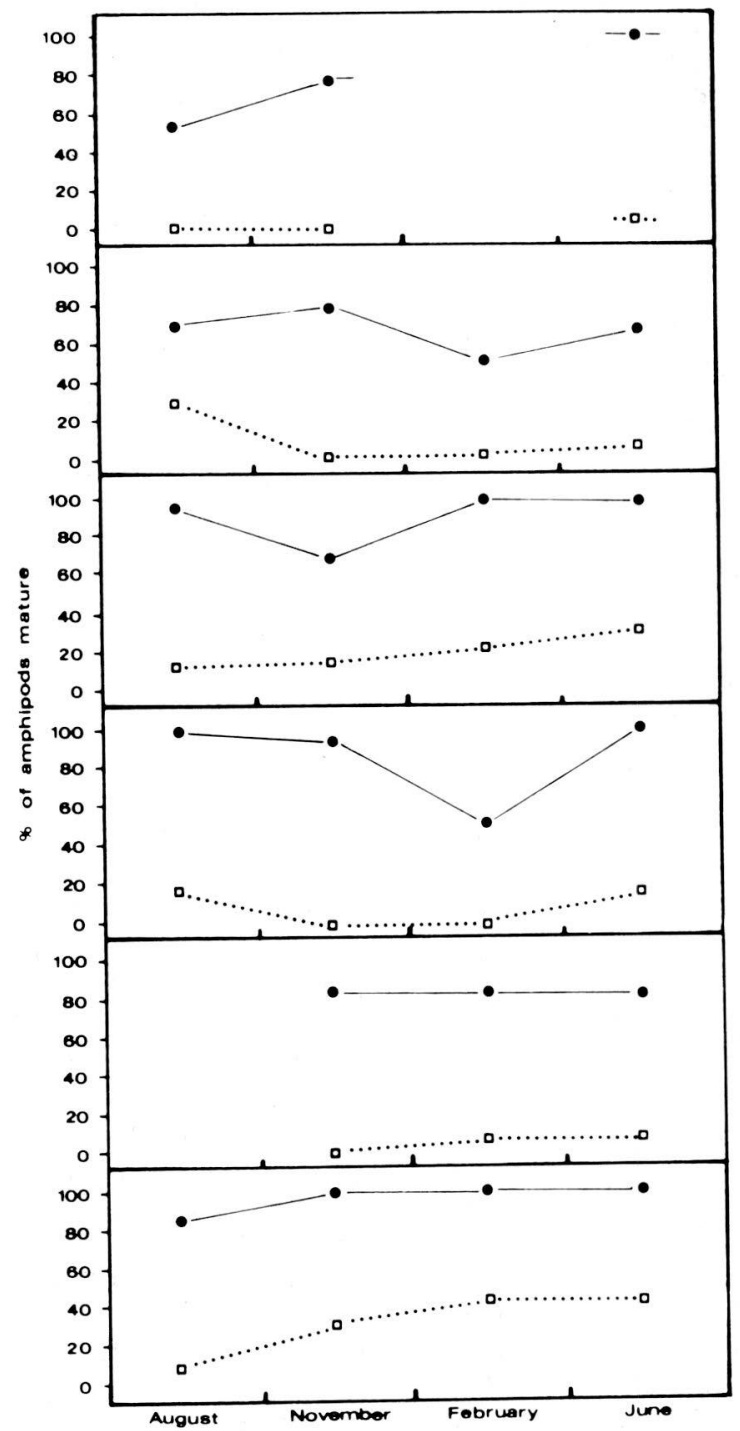

Fig. 2. The percentage of sexually mature individuals in populations of $C$. antennatus during seasonal collections. 
Table 2. Results of a two-way analysis of variance in sexual maturity of $C$. antennatus.

\begin{tabular}{|c|c|c|c|c|}
\hline & $\underset{\text { ratio }}{\mathrm{F}}$ & $\begin{array}{c}\text { Numerator } \\
\mathrm{df}\end{array}$ & $\begin{array}{l}\text { Denominator } \\
\text { df }\end{array}$ & $\mathrm{P}$ \\
\hline $\begin{array}{l}\text { Percentage } \\
\text { males mature } \\
\text { between caves }\end{array}$ & 4.3 & 5 & 13 & $\begin{array}{l}\text { Sig. } \\
\mathrm{P}<0.05\end{array}$ \\
\hline $\begin{array}{l}\text { Percentage } \\
\text { males mature } \\
\text { between seasons }\end{array}$ & 2.3 & 3 & 13 & $\begin{array}{l}\text { N.S. } \\
P>0.05\end{array}$ \\
\hline $\begin{array}{l}\text { Percentage } \\
\text { males mature } \\
\text { between habitats * }\end{array}$ & 2.3 & 1 & 13 & $\begin{array}{l}\text { N.S. } \\
P>0.05\end{array}$ \\
\hline $\begin{array}{l}\text { Percentage } \\
\text { females mature } \\
\text { between caves }\end{array}$ & 9.0 & 5 & 13 & $\begin{array}{l}\text { Sig. } \\
\mathrm{P}<0.01\end{array}$ \\
\hline $\begin{array}{l}\text { Percentage } \\
\text { females mature } \\
\text { between seasons }\end{array}$ & 9.0 & 3 & 13 & $\begin{array}{l}\text { Sig. } \\
\mathrm{P}<0.01\end{array}$ \\
\hline $\begin{array}{l}\text { Percentage } \\
\text { females mature } \\
\text { between habitats * }\end{array}$ & 0.7 & 1 & 13 & $\begin{array}{l}\text { N.S. } \\
\mathrm{P}>0.05\end{array}$ \\
\hline
\end{tabular}

* A priori tests.

and June in five of the six populations (Fig. 3). No ovigerous females were collected in Gallahan No. 2 Cave, whereas Roadside No. 1 Cave contained relatively large numbers during the entire year.

The number of eggs within the brood pouch of ovigerous females was found to be significantly greater $(\mathrm{F}(1,19)=10.5 ; \mathrm{P}<0.01)$ in pool-dwelling populations $(\bar{X}=42)$ than in those living in stream habitats $(\bar{X}=28)$. A significant linear relationship is present between female body length and egg number $(\mathrm{n}=23 ; \mathrm{r}=0.519 ; \mathrm{P}<0.01)$. Mean egg size from both habitats was also calculated $(n=70 ; \bar{X}=0.49 \mathrm{~mm}$ diameter $)$.

The number of juveniles collected in stream populations was greater than from pool habitats (Fig. 3). No circannian pattern of juvenile presence in populations was apparent in seasonal sampling.

Longevity. Crangonyx antennatus survived readily under laboratory conditions with very little mortality. As reported in a previous study (Dickson, 1979), after two years of growth in the laboratory, juveniles from Molly Wagle Cave were found to be less than half the average adult size. During the preparation of this paper (August 1978), these amphipods were over four years old and still were not of adult body length. Additional adult individuals from both pool and stream populations have been kept in the laboratory for 
Juvenlles $\rightarrow-$
Ovigerous : 0 .
fomales

Gallohan 2

Spangler

Cope

Molly Wagle

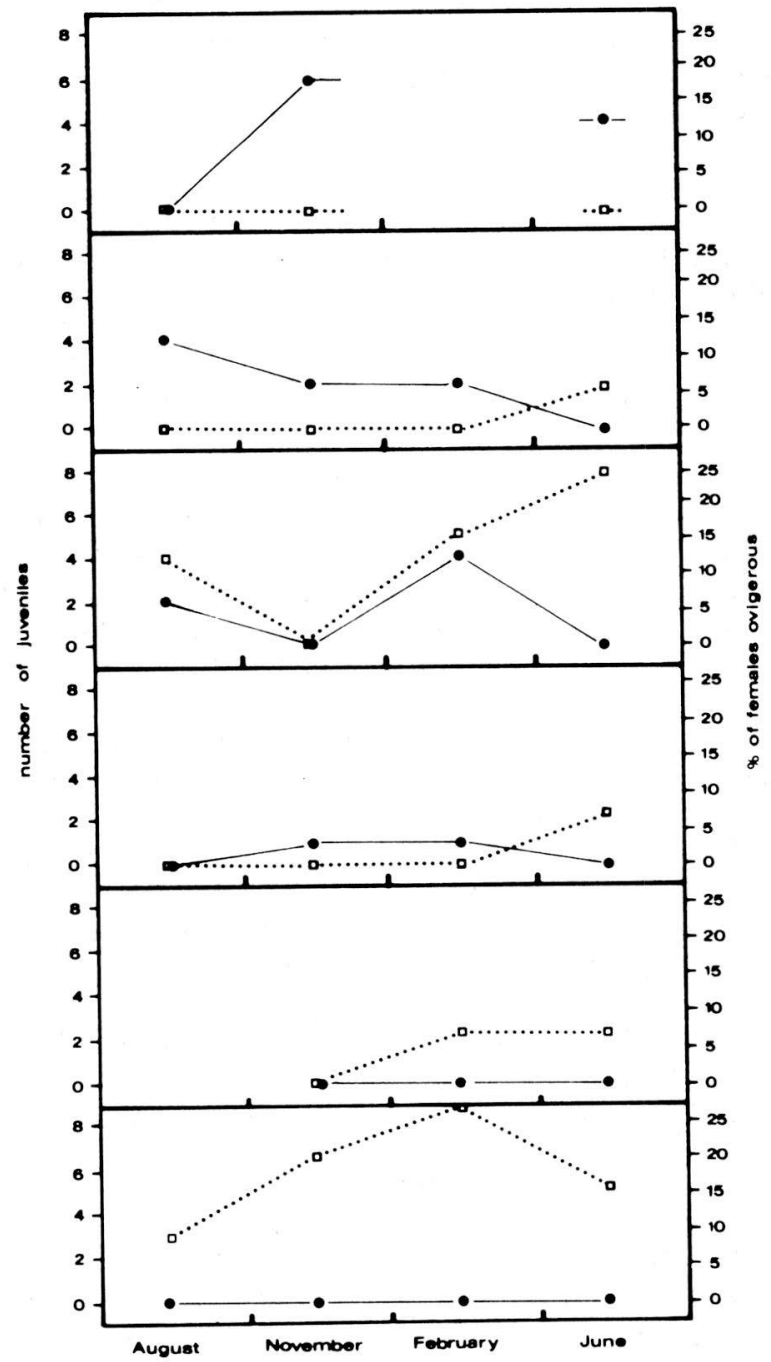

Fig. 3. The number of juveniles and the percentage of females which were ovigerous in $C$. antennatus populations from each cave during seasonal collection periods. 
a period of three to four years from the time of collection. It is inferred from laboratory cultures that $C$. antennatus may live as long as 8 to 10 years in nature.

Population Structure. The structure of $C$. antennatus populations was observed to be relatively constant in both pool and stream habitats over the year examined (Fig. 4). The largest population category was immature females, whereas mature females and juveniles made up the smallest groups. One exception to this generalized structure was the population inhabiting Roadside No. 1 Cave, which contained greater numbers of mature males and females.

Population Stability. The structure of $C$. antennatus populations was found to be stable over a 10-year period in both stream and pool habitats. Immature females were observed to be the largest population class; mature females and juveniles were the smallest classes (Fig. 5).

\section{DISCUSSION}

Results from the present study indicate that $C$. antennatus populations exhibit certain K-selected characteristics, including highly structured populations with selective maturity, low reproductive rates, and increased longevity. In addition to these generalized features, which are believed to be the products of selection, some population flexibility was observed due to individual habitat influence.

The sex ratios of $C$. antennatus were found to be more similar to an epigean congener, $C$. richmondensis, than to troglobitic species of Stygobromus (Table 1). This may indicate that the sex ratio of $C$. antennatus has not reached the level of cave specialization exhibited in the highly female dominated populations of troglobitic Stygobromus (Culver and Holsinger, 1969).

Populations of $C$. antennatus in stream and pool habitats were found to contain large numbers of sexually mature males $(\bar{X}=84 \%)$ throughout the year (Fig. 2). The high percentage of sexually mature males may increase the chance of breeding success by allowing mature males to be available in the population when conditions are periodically favorable for female maturation. In contrast, the number of mature females was relatively low $(\bar{X}=$ $13 \%$ ), with an increase observed in both habitats during spring and summer. This increase probably represents a response to more favorable food conditions.

In populations of all but one cave (Gallohan No. 2), seasonal fluctuations were observed in the number of ovigerous females (Fig. 3). The highest percentage of ovigerous females was seen in June, with initial increases in February. This seasonal peak may indicate a circannian reproductive pattern which follows increasing food availability and more optimal hydrological conditions. Ovigerous females were collected during other seasons only in the relatively food-rich habitats of Roadside No. 1, Molly Wagle, and Cope caves. This suggests that available food is one of the major factors controlling 


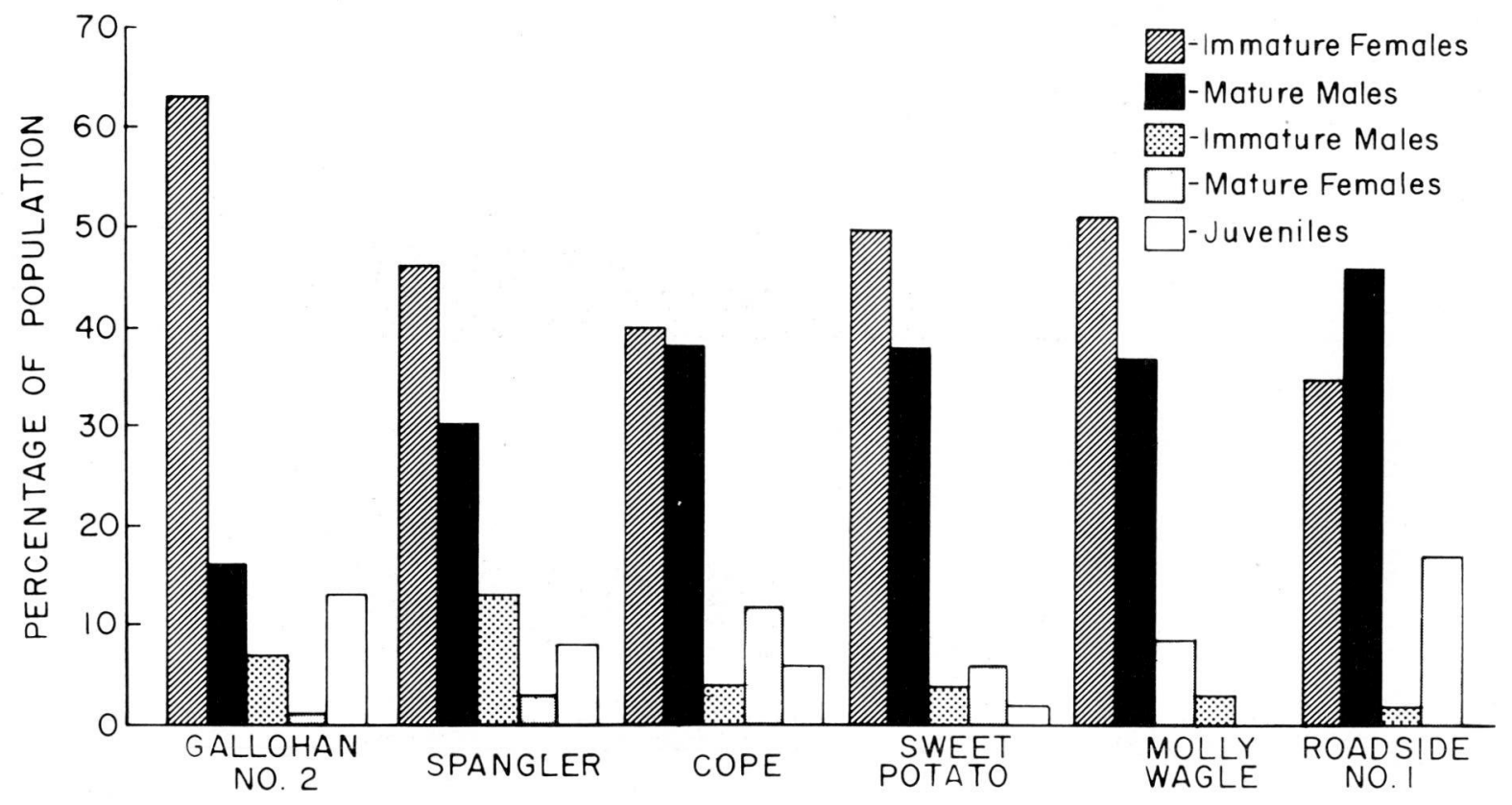

Fig. 4. Population structure of C. antennatus from the six investigated caves based on the total of four seasonal collections. 


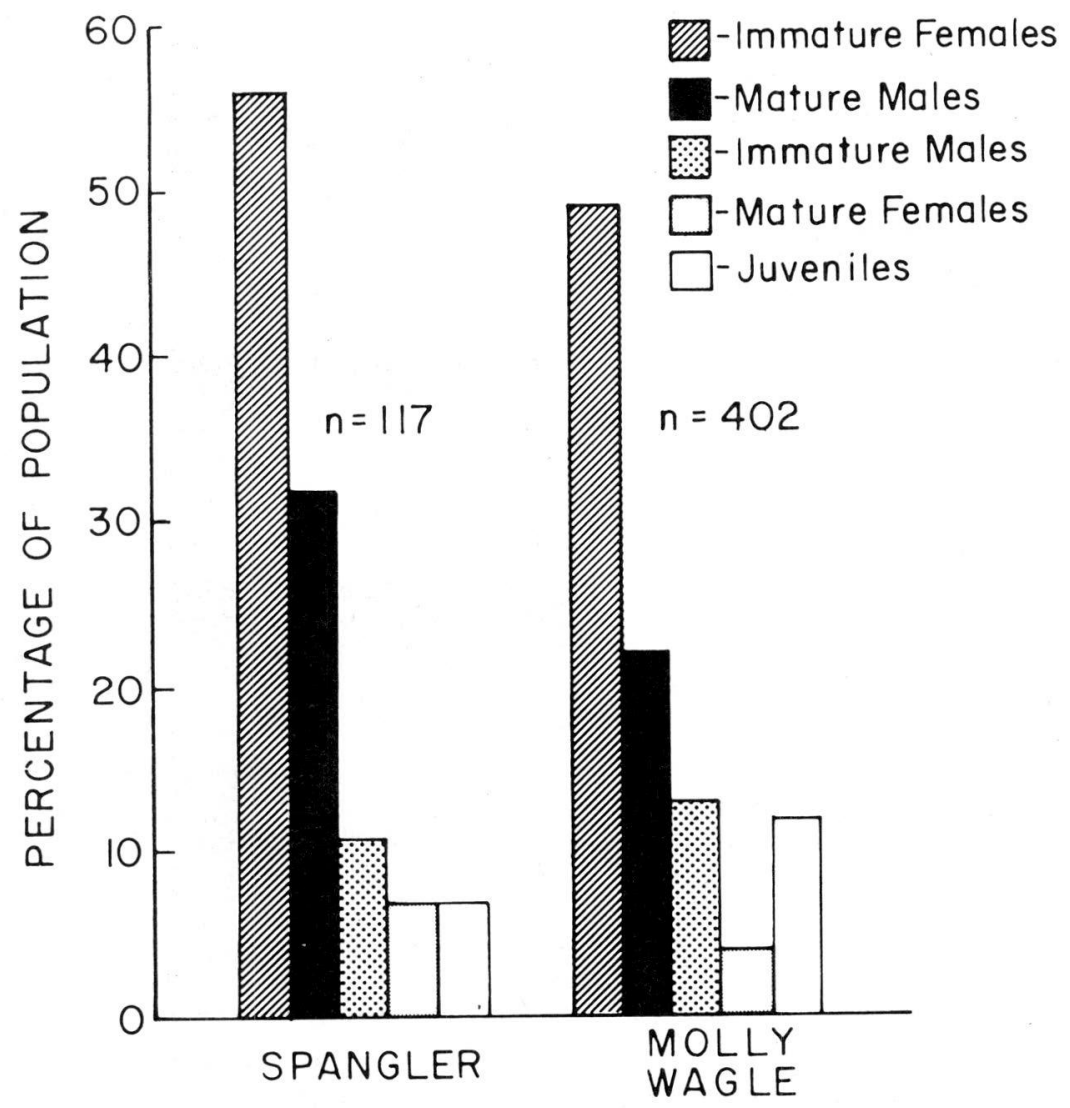

Fig. 5. Long term $C$. antennatus population structures from Molly Wagle and Spangler caves. Population class percentages based on the total number of individuals collected in periodic sampling from 1965 to 1975 . Population structure of individual collections almost always reflected these overall features. 
the egg productivity in $C$. antennatus. As further evidence, no ovigerous females were observed during the entire year in Gallohan No. 2 Cave, the most foodpoor habitat studied. Circannian reproductive patterns have been reported in other troglobitic crustaceans, including crayfish (Jegla, 1966; Jegla and Poulson, 1971; Hobbs, 1973, 1976; Cooper, 1975, 1978), shrimp (Barr and Kuehne, 1971; Cooper, 1975; Cooper and Cooper, 1974), amphipods (Ginet, 1960, 1969; Gledhill and Ladle, 1969), isopods (Magniez, 1975, 1976; Henry, 1976), and copepods (Husson, 1971).

Ovigerous females carried more eggs per clutch in pool-dwelling populations than in stream-dwelling populations. Based on the linear relationship between body length and egg number, clutch size appears to be influenced by larger females associated with the pool habitat (Dickson, 1977a). Increase in egg number correlated with increasing female body length has been observed in other amphipods (Kinne, 1961; Cooper, 1965; Gledhill and Ladle, 1969; Strong, 1972), although this relationship is not always linear (Sprules, 1967).

In $C$. antennatus (pool and stream populations lumped), the mean clutch size is 36 and the number of eggs per mm of female body length is 3.8. In a study of the epigean amphipod Crangonyx richmondensis laurentianus from a lake in Ontario, Canada, Sprules (1967) determined the mean clutch size of this population to be 43 , and based on the data given in his paper, the number of eggs per $\mathrm{mm}$ of female body length would be 3.12. Sprules also found the mean egg diameter to be 0.54 . Both the clutch size and number of eggs per mm of body length in this epigean species is a little larger than those values calculated for $C$. antennatus, although the mean egg size is slightly lower. However, in comparison with troglobitic amphipods of the genus Stygobromus, the mean clutch size and number of eggs per $\mathrm{mm}$ of body length in C. antennatus are relatively large. For example in Stygobromus mackini from caves in southwestern Virginia and northeastern Tennessee, the mean clutch size is 6.43 and the number of eggs per $\mathrm{mm}$ of female body length is 0.95 ; in S. spinatus from caves in southern West Virginia, the mean clutch size is 5.15 and the number of eggs per mm of body length is 0.96 (see Holsinger, 1978). The larger number of eggs per unit of body length in $C$. antennatus, which is closely similar to that of at least one population of epigean congener, may indicate a lower level of adaptation of this species to the subterranean environment than is present in species of Stygobromus. This tends to support the findings of Holsinger (1969) and Culver (1976) who concluded that C. antennatus was less specialized as a troglobite than species of Stygobromus.

The distinct pattern in the number of juveniles in pool habitats may be due to two processes. Although no direct observations were made, evidence of adult cannibalism of juveniles occurred in laboratory cultures (Holsinger and Dickson, 1977). Cannibalism also may be occurring in the densely populated pool populations (Dickson, in press) as was reported in populations of Niphargus (Ginet, 1960). Another possible explanation is the general avoidance activity of juvenile $C$. antennatus in relation to adults. In laboratory cultures, extreme avoidance reactions of juveniles have been observed in confrontations with adults, along with an increase in juvenile burrowing and congregation in crevices and other areas which exclude adults. Both of these 
processes, cannibalism and avoidance, may be occurring in the densely populated pool habitats, causing the low number of juveniles.

Data from laboratory cultures suggest that life span of $C$. antennatus may extend from 8 to 10 years. This life span far exceeds that of epigean amphipods, which generally live one to two years (Pennak, 1953; Hynes, 1954; Sprules, 1967). Increased longevity has been observed in other troglobitic crustaceans. Ginet (1960) reported that the amphipod Niphargus orcinus virei may have a life span of six years. Several subspecies of the isopod Stenasellus virei have been estimated to live 12 to 15 years (Magniez, 1975). Data from a long term, in situ, study suggest the possibility that the troglobitic crayfish Orconectes australis australis may live more than 37 years (Cooper, 1975; Cooper and Cooper, 1976). This increased longevity is considered to be an adaptation associated with population stability in the energy limited cave environment.

Population stability also can be enhanced through the maintenance of specific population structures. Crangonyx antennatus populations display such a modified structure. Populations are characterized by large numbers of immature females and mature males, with a very small percentage of mature females (Fig. 4). There appears to be some form of female recruitment in $C$. antennatus from the immature to the mature stage. An explanation (see Emlen, 1973) may be given for the presence of late female maturity compared to the early maturation of males in this species. Crangonyx antennatus females have been found to produce larger numbers of eggs with increasing body length, thus maximum fecundity occurs in larger (i.e., older) females. Because reproductive activities at one age may diminish the chances of surviving to reproduce at later ages, selection pressure would oppose early reproduction. Survival of female $C$. antennatus through egg bearing periods could be affected by increased energy expenditures associated with egg production, greater susceptibility to predation, and the possibility of additional molting accidents. Overall reproductive success would be expected to be affected more by egg number than sperm number, so selection for late maturity should be stronger in females than males. The low percentage of mature females would also allow a means of controlling population size prior to expenditure of energy in egg formation.

The mechanism of sexual maturation in females is unknown at this time. Reaching a specific size range does not appear to trigger maturation, as many of the immature females are larger than mature females (Dickson and Holsinger, unpublished data).

The population structure of $C$. antennatus was constant both over the year studied and in different aquatic habitats (Fig. 4). In epigean amphipods, population structure changes seasonally, reflecting the growth and maturation of annual or biennial generations (Hynes, 1954; Sprules, 1967). Based on collections from both a pool and a stream, the structure of $C$. antennatus populations was also found to be temporally stable over a 10 -year period.

In $C$. antennatus, the selection of a highly structured population adapted to subterranean conditions apparently outweighs the selective pressures caused by different aquatic habitats. Populations inhabiting lotic and lentic si- 
tuations exhibit quite similar population structures, but they possess morphological and behavioral differences (Dickson, 1977a, 1977b). From these data, it appears that in $C$. antennatus group selected characteristics (population structure) are less variable than individually selected traits (morphology, rheotactic behavior). Emlen (1973) states that under food limited situations group selection becomes an important process. Reproductive patterns were not found to differ in the troglobitic crayfish, Orconectes inermis inermis living under different conditions of food availability (Jegla et al., 1965). In contrast, the epigean amphipod Hyalella azteca exhibited shifts in population structure associated with habitat differences (Strong, 1972). The one exception to the generalized population structure in $C$. antennatus was found in Roadside No. 1 Cave, but the characteristics of this population may be due in part to the presence of an unusually rich food source (raccoon dung).

With respect to egg productivity (i.e., the number of eggs per $\mathrm{mm}$ of $\mathrm{fe}$ male body length), $C$. antennatus is more similar to at least one epigean congener than it is to troglobitic species of Stygobromus. But aside from this, $C$. antennatus has apparently evolved the other K-selected characteristics normally associated with troglobite specialization. In a recent study by Franz (1978) on the troglobitic crayfish Procambarus (Ortmannicus) lucifugus and $P$. (Ortmannicus) erythrops living in food-rich cave systems in Florida, the number of eggs produced by these species was found to be potentially as large as that of a closely related epigean species living in the same general area. Based on our observations of $C$. antennatus and those of Franz (1978) on crayfish, it appears that variation in egg productivity in less specialized troglobites may be influenced by environmental factors such as the availability of food. However, a decrease in egg number as one of the final steps in adaptation to a cave-dwelling existence should be viewed with some caution.

\section{ACKNOWLEDGMENTS}

For assistance with the field work we wish to thank George D. Corbett, David C. Culver, Jeanne Dickson, James A. Estes, Carol J. Haley, Stephen W. Hetrick, and David Wapinski. We are grateful to Mrs. Eleanor Berry, owner of Molly Wagle Cave, and to other cave owners in Lee Co., Virginia, for their cooperation in allowing us access to their property.

\section{ZUSAMMENFASSUNG}

Populationen des unterirdischen Amphipod Crangonyx antennatus in Höhlen im Lee Co., Virginia (U.S.A.) wurdenauf einer kurzfristigen un einer langfristigen Basis untersucht. Die Dynamik von Populationen die in zwei verschiedenen Höhlenfundorten (schlammgrundige Teiche und steingrundige Flüsse) leben wurden jahreszeitsweise für ein Jahr verglichen. Das Verhältnis von Mannchen zu Weibchen deutete eine grössere Anzahl von Weibchen im Teich sowohl als auch im Fluss an. Die Mehrzahl der Männchen an beiden Fundorten waren während der ganzen Jahreszeit uber geshclechtsfähig. Jahreszeitliche Schwankungen in der Geschlechtsreife der Weibchen konnte an beiden Fundorten beobachtet werden, wobei die Anzahl der gesammelten Weibchen im Juni und August grösser war. Ausserdem wurde eine grössere Anzahl von eierlegenden Weibchen im Frühjahr beobachtet, was die Möglichkeit eines circannischen Fortpflanzungszykluses im Teich und Fluss andeutet. Die Struktur der untersuchten Populationen in Höhlen scheint die kontrollierte Umwandlung von geschlechtlich unreifen zu geschlechtlich reifen Weibchen zu reflektieren. 
Um die stabilität der Populationenstruktur zu bestimmen, wurden Werte von einer 10 jährigen Zeitspanne eines Teich- und Flussfundortes analyziert. Die Populationenstruktur zeigten eine relative Stabilität, uber lange Zeitspannen an beiden Fundorten, wobei die geschlechtlich unreifen Weibchen die herrschende Populationenklasse bildeten.

\section{LITERATURE}

BARR, T.C., Jr., and R.A. KUEHNE 1971. Ecological studies in the Mammoth Cave system of Kentucky. II. The ecosystem. Annales de Spéléol. 26:2-96.

COOPER, J.E. 1975. Ecological and behavioral studies in Shelta Cave, Alabama, with emphasis on decapod crustaceans. Unpublished doctoral dissertation, University of Kentucky.

COOPER, J.E., and M.R. COOPER 1974. Distribution and ecology of troglobitic shrimp of the genus Palaemonias (Decapoda: Atyidae). Assoc. Southeastern Biol. Bull. 21:48 (abstr.).

COOPER, J.E., and M.R. COOPER 1978. Comparative reproductive strategies of troglobitic crayfishes in Shelta Cave, Alabama. Assoc. Southeastern Biol. Bull. 25:44 (abstr.).

COOPER, M.R., and J.E. COOPER 1976. Growth and longevity in cave crayfishes. Assoc. Southeastern Biol. Bull. 23:52 (abstr.).

COOPER, W.E., 1965. Dynamics and production of a natural population of a freshwater amphipod, Hyalella azteca. Ecol. Monogr. 35:377-394.

CULVER, D.C. 1976. The evolution of aquatic cave communities. Am. Nat. 110:945-957.

CULVER, D.C., and J.R. HOLSINGER 1969. Preliminary observations on sex ratios in the subterranean amphipod genus Stygonectes (Gammaridae). Am. Midl. Nat. 82:631-633.

DICKSON, G.W. 1977a. Variation among populations of the troglobitic amphipod crustacean Crangonyx antennatus Packard living in different habitats. I. Morphology. Int. J. Spéléol. 9:43-58.

DICKSON, G.W. 1977b. Behavioral adaptation of the troglobitic amphipod crustacean Crangonyx antennatus to stream habitats. Hydrobiologia 56:17-20.

DICKSON, G.W. 1979. The importance of cave mud sediments in food preference, growth and mortality of the troglobitic amphipod crustacean Crangonyx antennatus Packard (Crangonyctidae). Crustaceana 36:129-140.

DICKSON, G.W. In press. Variation among populations of the troglobitic amphipod crustacean Crangonyx antennatus Packard (Crangonyctidae) living in different habitats. II. Population distribution. Int. J. Spéléol.

DICKSON, G.W. and P.W. KIRK, Jr. 1976. Distribution of heterotrophic microorganisms in relation to detritivores in Virginia caves. (With supplementary bibliography on cave mycology and microbiology), in: The distributional history of the biota of the southern Appalachians. Part IV. Algae and fungi, PARKER B.C. and ROANE M.K., Eds., University Press of Virginia, Charlottesville: 205-226.

EMLEN, J.M. 1973. Ecology: An evolutionary approach. Addison-Wesley, California.

FRANZ, R. 1978. Ecological strategies of closely-related surface and troglobitic Florida crayfishes. Bull. Ecol. Soc. Am. 59:70 (abstr.).

GINET, R. 1960. Écologie, éthologie et biologie de Niphargus (Amphipodes, Gammarides hypogés). Annales de Spéléol. 15:127-376.

GINET, R. 1969. Rythme saisonnier des reproductions de Niphargus (Crust. Amph. hypoge). Annales de Spéléol. 24:387-397.

GLEDHILL, T. and M. LADLE 1969. Observations on the life-history of the subterranean amphipod Niphargus aquilex aquilex Schiodte. Crustaceana 16:51-56.

HENRY, J.P. 1976. Recherces sur les Asellidae hypogés de la lignés cavaticus (Crustacea, Isopoda, Asellota). Unpublished doctoral thesis, Université de Dijon, France.

HEUTS, M.J. 1951. Ecology, variation and adaptation of the blind African cave fish, Caecobarbus geertsi. Annales Soc. Roy. Zool. Belgium 82:155-230.

HOBBS III, H.H. 1973. The population dynamics of cave cray fishes and their commensal ostracods from southern Indiana. Unpublished doctoral dissertation, Indiana University.

HOBBS III, H.H. 1976. Molt cycle, size and growth in Orconectes inermis inermis Cope (Decopoda: Cambaridae). Va. J. Sci. 27:44 (abstr.).

HOLSINGER, J.R. 1969. Biogeography of the freshwater amphipod crustaceans (Gammaridae) 
of the central and southern Appalachians, in: The distributional history of the biota of the southern Appalachians. Part I. Invertebrates, HOLT P.C., Ed., Virginia Polytechnic Institute Press, Blacksburg, Va.: 19-50.

HOLSINGER, J.R. 1972. The freshwater amphipod crustaceans (Gammaridae) of North America. Biota of Freshwater Ecosystems, Identification Manual 5, U.S. Environmental Protection Agency.

HOLSINGER, J.R. 1978. Systematics of the subterranean amphipod genus Stygobromus (Crangonyctidae), Part II: Species of the eastern United States. Smithsonian Contributions to Zoology No. 266:1-144.

HOLSINGER, J.R. and C.H. HOLSINGER 1971. Observations on the population ecology of the cavernicolous amphipod crustacean Crangonyx antennatus Packard. Va. J. Sci. 22:97 (abstr.).

HOLSINGER, J.R. and G.W. DICKSON 1977. Burrowing as a means of survival in the troglobitic amphipod crustacean Crangonyx antennatus Packard (Crangonyctidae). Hydrobiologia 54:195-199.

HUSSON, R. 1971. Rythmes biologiques et vie cavernicole. Bull. Soc. Zool. France 96:301-316.

HYNES, H.B.N. 1954. The ecology of Gammarus dueboni Lilljeborg and its occurrence in fresh water in western Britain. J. Anim. Ecol. 23:38-84.

JEGLA, T.C. 1966. Reproductive and molting cycles in cave crayfish. Biol. Bull. 130:345-358.

JEGLA, T.C. and T.L. POULSON 1970. Circannian rhythms-I. Reproduction in the cave crayfish, Orconectes pellucidus inermis. Comp. Biochem. Physiol. 33:347-355.

JEGLA, T.C., T.L. POULSON and M.R. COOPER 1965. Interpopulation variations in a cave crayfish (Orconectes pellucidus). Am. Zool. 5:639 (abstr.).

KINNE, O. 1961. Growth, molting frequency, heart beat, number of eggs, and incubation time in Gammarus zaddachi exposed to different evironments. Crustaceana 2:26-36.

MACARTHUR, R.H. and E.O. WILSON 1967. The theory of island biogeography. Princeton University Press, New Jersey.

MAGNIEZ, G. 1975. Observations sur la biologie de Stenasellus virei. Int. J. Spéléol. 7:79-228.

MAGNIEZ, G. 1976. Remarques sur la biologie et l'ecologie de Stenasellus virei Dollfus (Crustacea, Isopoda Asellota des eaux souterraines) Int. J. Spéléol. 8:135-140.

PENNAK, R.W. 1953. Freshwater invertebrates of the United States. Ronald Press, New York. POULSON, T.L. 1963. Cave adaptation in Amblyopsid fishes. Am. Midl. Nat. 70:257-290.

SPRULES, W.G. 1967. The life cycle of Crangonyx richmondensis laurentianus Bousfield (Crustacea: Amphipoda). Can. J. Zool. 45:877-884.

STRONG, D.R. 1972. Life history variation among populations of an amphipod (Hyalella azteca). Ecology 53:1103-1111.

TURNER, R.D. and W.J. CLENCH 1974. A new blind Physa from Wyoming with notes on its adaptation to the cave environment. Nautilus: 88:80-85.

VANDEL, A. 1965. Biospeleology. The biology of cavernicolous animals. Pergamon Press, New York. 
Int. J. Speleol. 11 (1981), pp. 49-62.

\title{
Some Implications of Competition for Cave Stream Communities
}

\author{
David C. Culver*
}

\begin{abstract}
SUMMARY
Based on recent theoretical work by Robert May and Richard Levins, two hypotheses about time fluctuations in abundance of competing species were generated. Data for isopods and amphipods from four cave stream communities in Virginia and West Virginia were used to test the predictions. First, variance of total abundance should be less than the sum of the variances of individual species' abundances. In three of four communities studied, the prediction was confirmed, but none were statistically significant. Positive correlations among carrying capacities of competing species may explain the poor agreement with predictions. Second, the signs of 19 correlations and partial correlations of species abundances were predicted on the basis of relative magnitudes of direct and indirect effects of competition, and of these predictions, 16 were confirmed by the data, including 5 statistically significant ones. Most interesting was the finding that competitors can be positively correlated.
\end{abstract}

As Poulson and White (1969) point out, caves can be important "laboratories" for testing and elaborating on ecological models and theories. The purpose of this paper is to explore some of the consequences of intraspecific and interspecific competition for the structure and dynamics of some aquatic cave communities.

The data to be analyzed are from cave streams in the south central Appalachians. These cave streams contain between two and four competing amphipod and isopod species. Considerable evidence has been marshalled in previous publications (Culver, 1970, 1971, 1973, 1976) that the amphipods and isopods in these streams compete primarily for space, and this evidence will not be reviewed here. Rather, competition is assumed to be occurring in the communities being studied, and the consequences of competition for temporal changes in species abundance will be pursued.

These communities are especially appropriate for the study of competition models because the dynamics of the interaction $\left(f_{j}\right)$ are fairly well described by the standard competition equations:

$$
\mathrm{f}_{\mathrm{i}} \approx \frac{\mathrm{dN} \mathrm{N}_{\mathrm{i}}}{\mathrm{dt}}=\frac{\mathrm{r}_{\mathrm{i}} \mathrm{N}_{\mathrm{i}}}{\mathrm{K}_{\mathrm{i}}}\left(\mathrm{K}_{\mathrm{i}}-\sum_{\mathrm{j}=1}^{\mathrm{n}} \alpha_{\mathrm{ij}} \mathrm{N}_{\mathrm{j}}\right)
$$

* Department of Biological Sciences Northwestern University, Evanston, Illinois 60201 U.S.A. . 
where $\mathrm{N}_{\mathrm{i}}$ is the population size of species $\mathrm{i}, \mathrm{r}_{\mathrm{i}}$ is its intrinsic rate of increase, $\mathrm{K}_{\mathrm{i}}$ is the carrying capacity of the environment for species $\mathrm{i}$, and $\alpha_{\mathrm{ij}}$ is the effect of an individual of species $\mathrm{j}$ on an individual of species $\mathrm{i}\left(\alpha_{\mathrm{ii}}=1\right)$. Some of the assumptions contained in equation [1], such as the constancy of the carrying capacity and the absence of higher order terms, make equation [1] inappropriate for some communities (e.g., Neill, 1974). However, they seem to work quite well in cave stream communities for several reasons (Culver, 1973, 1976). First, populations appear to be near equilibrium and aside from periods of spring flooding, population sizes vary less than populations in epigean streams (Culver, 1971). Other researchers (e.g., Gledhill, 1977) have remarked on the relative constancy of subterranean aquatic faunas. Second, the communities are simple, with between two and four interacting species. This reduces the mathemaical chances of cyclic or chaotic behavior of population sizes (Smale, 1976). Third, the interactions between species are behaviorally simple and highly stereotyped (Culver, 1970), and thus they are unlikely to result in complicated, higher order interaction terms resulting from density or age differences. These conditions taken together indicate that communities should be at or near the equilibrium:

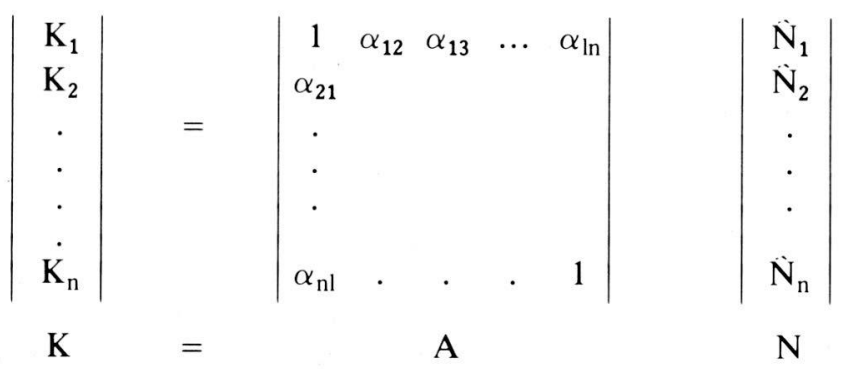

where $\hat{N}_{i}$ is the equilibrium population size of species $i$.

The pioneering theoretical work by May (1974a) and Levins (1975) has resulted in a series of predictions being made about communities of competitors near equilibrium. In this paper, two of these predictions will be examined:

(1) the variation in total abundance of all species combined over time should be less than variation over time of population size of individual species.

(2) the partial correlation of abundances of competing species over time should be negative but correlations can be positive if indirect competition is important.

Although the genesis of these predictions comes from mathematical ecology, a verbal description of each prediction will be given first for the aid of readers who are not mathematically inclined. A synopsis of the mathematical argument will follow.

Time series data for four caves in Virginia and West Virginia form the 
data base for this study. Species compositions for these four caves are given in Table 1.

Table 1. Species compositions for the four communities studied. Data on individual species abundances through time are given in Appendix 1. Data for Spangler and Gallohan Cave No. 2 are from Dickson (1976); data for Gallohan Cave No. 1 are from unpublished work of James Estes; data for Court Street Cave are the author's.

\begin{tabular}{lcccc}
\hline SPECIES & $\begin{array}{c}\text { Court } \\
\text { Street }\end{array}$ & $\begin{array}{c}\text { Gallohan } \\
\text { No. 1 }\end{array}$ & $\begin{array}{l}\text { Gallohan } \\
\text { No. 2 }\end{array}$ & Spangler \\
\hline $\begin{array}{l}\text { AMPHIPODA } \\
\begin{array}{l}\text { Crangonyx antennatus } \\
\text { Stygobromus emarginatus }\end{array}\end{array}$ & $\mathrm{X}$ & $\mathrm{X}$ & $\mathrm{X}$ & $\mathrm{X}$ \\
$\begin{array}{l}\text { Stygobromus spinatus } \\
\text { ISOPODA }\end{array}$ & $\mathrm{X}$ & & & \\
$\begin{array}{l}\text { Caecidotea recurvata } \\
\text { Lirceus usdagalun } \\
\text { Pseudobaicalasellus holsingeri* }\end{array}$ & & $\mathrm{X}$ & $\mathrm{X}$ & $\mathrm{X}$ \\
\hline
\end{tabular}

* The genus Pseudobaicalasellus proposed by Herny and Magniez has not been critically examined by North American Taxonomists (see Bowman, 1975).

\section{PATTERNS OF TOTAL ABUNDANCE}

Imagine a cave stream where the availability of food or some other limiting factor remains roughly constant. That is, the total number of individuals (or total biomass) that the habitat can support remains constant, assuming ecological efficiencies of competing species do not vary greatly. So long as there has been sufficient time for a population or populations to reproduce to reach this maximum, the intensity of interspecific competition has little effect on the total number of individuals (or biomass) in the community. On the other hand, variation in abundance or biomass of individual species would increase with increasing interspecific competition. Therefore, we would predict that total abundance should vary less than the abundance of individual species.

The hypothesis can be framed in a more rigorous way as follows. For the equilibrium in equation [2] to be stable, the eigenvalues of A must have positive real parts (Strobeck, 1973). [For a discussion of eigenvalues see Searle (1966)] The real parts of the eigenvalues measure the rate of return of the community to the equilibrium following a perturbation. Associated with each eigenvalue is an eigenvector, which is a linear combination of the variable of the differential equation underlying the process. In this case, the variables are population sizes, or deviations of population sizes from the equilibrium point. The rate of return following a particular perturbation depends on 
which eigenvector(s) most closely approximates the perturbation. For example, if in a three species community the abundances of the first two species are increased and the abundance of a third is decreased, then the rate of return to equilibrium will be governed by eigenvalues associated with eigenvectors whose first two elements are positive and last one is negative. An important consequence of the assumption that all species are competing (i.e., $\alpha_{\mathrm{ij}}>0$ ) is that the eigenvector associated with the largest eigenvalue has all positive coefficients and all other eigenvectors have at least one negative coefficient- -the Perron-Frobenius Theorem (Gantmacher, 1959). Therefore, a perturbation that changes the abundance of all species will disappear more quickly than other perturbations. For many matrices with biologically reasonable values for $\alpha_{\mathrm{ij}}$, all of the coefficients of the eigenvector are one (May, 1974b), and the sum of the elements of the eigenvector corresponds exactly to total abundance. Any perturbation of the community aside from one involving total abundance will have a slower rate of return to equilibrium since it will be controlled by smaller eigenvalues. Figure 1 is a graphical representation of this hypothesis for two competitors.

The hypothesis to be tested is that for time-series data, the variance of total abundance $\left(\mathrm{V}_{\mathrm{T}}\right)$, which is controlled by the largest eigenvalue, is less than the sum of the individual species' variance $\left(\mathrm{V}_{\mathrm{i}}\right)$, which are controlled by the other, smaller eigenvalues. This can be statistically tested by using an F-test:

$$
\frac{\sum_{\mathrm{i}=1}^{\mathrm{n}} \mathrm{V}_{\mathrm{i}}}{\mathrm{V}_{\mathrm{T}}}=\mathrm{F}[(\mathrm{m}-1)(\mathrm{n}),(\mathrm{m}-1)]
$$

for $\mathrm{n}$ species and $\mathrm{m}$ sampling dates. Since

$$
\mathrm{V}_{\mathrm{T}}=\sum_{\mathrm{i}=\mathrm{l}} \mathrm{V}_{\mathrm{i}}+\sum_{\substack{\mathrm{i}, \mathrm{j}=\mathrm{l} \\ \mathrm{j}>\mathrm{i}}}^{\mathrm{n}} 2 \operatorname{cov}\left(\mathrm{N}_{\mathrm{i}}, \mathrm{N}_{\mathrm{j}}\right)
$$

where $\mathrm{N}_{\mathrm{i}}$ is the abundance of species $\mathrm{i}$, then it follows that the sum of the covariances of species abundances for competing species is negative, as can be seen in figure $1 \mathrm{~B}$.

In three of the four caves, the variance of total abundance is less than the sum of the variances of abundances of individual species (Table 2). The variance ratios range from 2.39 in Gallohan Cave No.2 to 0.98 in Gallohan Cave No. 1. None are statistically significant. If variance ratios in Table 2 are typical for communities of competitors, sufficient data will rarely be available to demonstrate statistical significance.

All in all, the fit of the data to the prediction is poor. This may be due in part to small sample sizes, but it also seems likely that some other process is involved. The hypothesis above was generated for the situation where the 

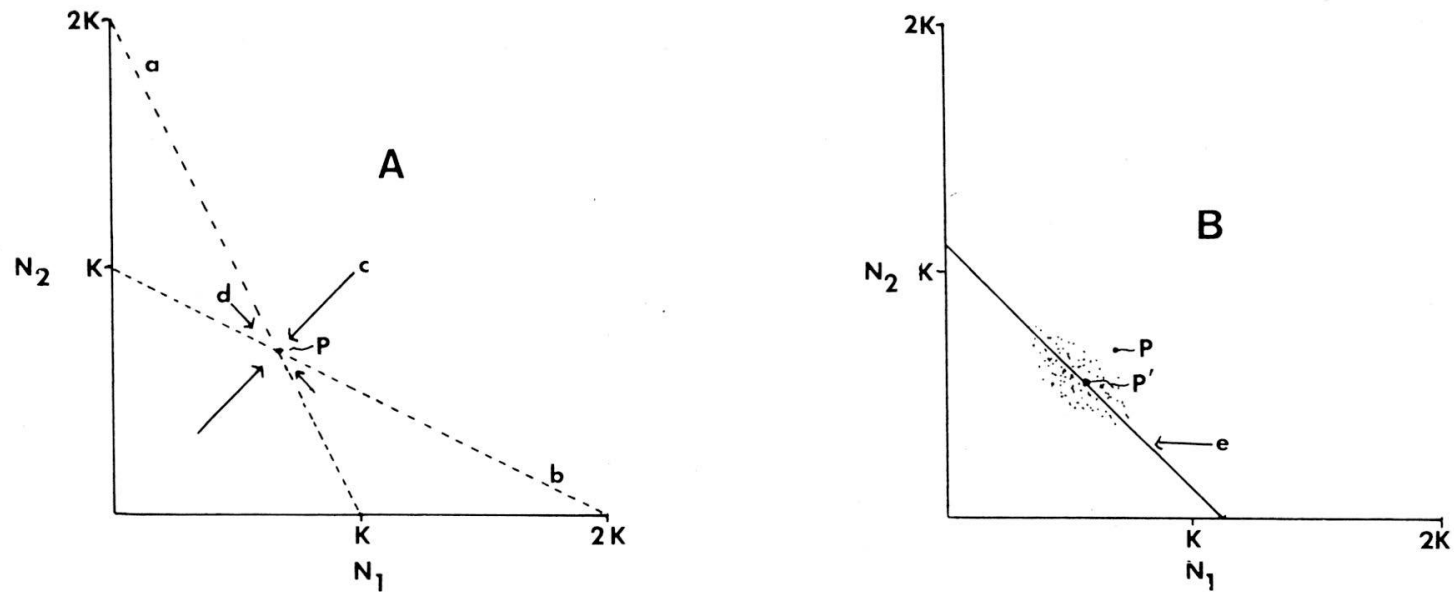

Fig. 1. An illustration of the hypothesis derived from the Perron-Frobenius Theorem for two competing species. The growth rate of each species is assumed to be $\mathrm{dN} / \mathrm{dt}=(\mathrm{rN} / \mathrm{K})\left(\mathrm{K}-\mathrm{N}-\alpha \mathrm{N}_{2}\right)$. In $\mathrm{A}$, the dashed lines are isoclines for the two species when $\alpha=0.5$. Line $\mathrm{a}$ is the isocline for species 1 anc line $b$ is the isocline for species 2 . The stable equilibrium point is $p$. The solid arrows are the two eigenvectors. The length of the arrow indicates the relative magnitude of the eigenvalue associated with the eigenvector. Assuming that $(\mathrm{r} N / \mathrm{K})=1$, eigenvector $\mathrm{c}$ is $(1,1)$ and $\lambda_{c}=1+\alpha$. This is the eigenvector of total abundance. The eigenvector $\mathrm{d}$ is $(1,-1)$ and $\lambda_{d}=1-\alpha$. This eigenvector is the difference in abundance of the two species. In B, the equilibrium distribution through time in a varying environment is indicated by the cloud of dots. The mean population sizes ( $\left.p^{\prime}\right)$ will be less than in the deterministic case (see May, 1973). Line e is a line for which $N_{1}+N_{2}=$ constant. The largest eigenvalue will tend to return populations to this line. Fluctuations along line e will be less strongly damped. 
Table 2. The ratio of the sum of the variances of individual species abundances $\left(\xi V_{j}\right)$ to the variance of total abundance $\left(\mathrm{V}_{\mathrm{T}}\right)$. If species are competing, this ratio should be greater than unity. The number of samples required for statistical significance $(\mathrm{P}>0.95)$ if the ratio observed is the true variance ratio, is listed in the column labelled $\mathrm{N}^{*}$.

\begin{tabular}{lcccc}
\hline Cave & No. of Species & No. of time samples & $\xi \mathrm{V}_{\mathrm{i}} / \mathrm{V}_{\mathrm{T}}$ & $\mathrm{N}^{*}$ \\
\hline Gallohan No. 1 & 3 & 4 & 2.39 & 12 \\
Court Street & 3 & 7 & 1.77 & 25 \\
Spangler & 2 & 4 & 1.12 & $>100$ \\
Gallohan No. 1 & 3 & 5 & 0.98 & $>100$ \\
\hline
\end{tabular}

equilibrium is fixed and the population sizes are subject to random perturbation about this equilibrium. But the equilibrium itself may vary, especially due to variation in the carrying capacity, K. May (1974a) has shown that if variation in $\mathrm{K}_{\mathrm{i}}$ is random (i.e., 'white noise'), the variance in total abundance should be less than the sum of the variances of individual species' abundances. This results in the same qualitative prediction about variances as does the consequences of the Perron-Frobenius Theorem discussed above. But if carrying capacities of competing species are positively correlated through time, then the variance in total abundance may exceed the sum of the variances of individual species' abundances. For example, if the carrying capacities of two competitors are both low in winter and high in summer, then species abundances might be positively correlated (see equation 3 ) even though they are competing. The mathematics of such cases of competitors with correlated carrying capacities has not been completely worked out (see Roughgarden, 1975), but the importance of correlation of K's can be seen for the following simple case. Let $\mathrm{r}_{\mathrm{i}} \hat{\mathrm{N}}_{\mathrm{i}} / \mathrm{K}_{\mathrm{i}}=1$ for all species and let all interspecific competition coefficients $\left(\alpha_{\mathrm{ij}}\right)$ be equal to a. It can be shown (Levins and Culver, unpublished) that the covariances of changes in abundance of species $i$ and $j$ is:

$$
\operatorname{cov}\left(\triangle N_{i}, \triangle N_{j}\right)=\frac{6_{k}^{2}\left[1+(n-1) a^{2}\right] p-(n-2) a^{2}}{(1-a)[1+(n-1) a]^{2}(n-1)}
$$

Where $\mathrm{p}$ is the product-moment correlation of $\mathrm{K}_{\mathrm{i}}$ and $\mathrm{K}_{\mathrm{j}}$, and $6_{\mathrm{K}}^{2}$ is the variance of $\mathrm{K}$, assuming each $\mathrm{K}_{\mathrm{i}}$ has the same variance. When the covariance in [4] is positive, all covariance will be positive due to symmetry, and the variance of total abundance $\left(\mathrm{V}_{\mathrm{T}}\right)$ will exceed the sum of variances $\left(\mathrm{V}_{\mathrm{i}}\right)$ of individual species abundances (see equation 3 ). This will occur when the correlation of carrying capacities exceed a certain value:

$$
p>\frac{(n-2) a^{2}}{1+(n-1) a^{2}}
$$

For example, for Gallohan Cave No. 1, the mean value of $\alpha$ is 0.9 , and the 
covariance will be positive if the correlation between $\mathrm{K}$ 's is 0.31 or greater, not an especially strong correlation. This line of reasoning cannot be pursued further because the correlation of K's is probably an unmeasureable quantity. Abundances of species themselves cannot be used since they are a result of both carrying capacity and interspecific competition. An independent estimate of $\mathrm{K}$ is needed, and that is not available.

\section{CORRELATIONS AND PARTIAL CORRELATIONS OF ABUNDANCE}

Another consequence of interspecific competition are correlations among species' abundance through time. When two species are competing, the abundances of the two species should be negatively correlated since an increase in one species should result in a decrease in the other. When three species are competing, the situation is more complicated. This is because species A affects species B in two ways. First, there is the direct negative effect of species A on species B. Second, there is the indirect positive effect of species A on species B via species C. That is, species A has a negative effect on species $C$, which has a negative effect on species B; so the overall indirect effect of species $\mathrm{A}$ on species $\mathrm{B}$ is positive. The correlation between the two species depends on the relative magnitude of these effects (Levine, 1976).

In order to make predictions about the sign of the correlation, we must look at the mathematics of the hypothesis a bit more carefully. For convenience and consistency, Levins' (1975) terminology and symbols will be used as much as possible. A change in the growth equations, $f_{i}$ (see equation 1), can be generally written as $\frac{\delta \mathrm{f}_{\mathrm{i}}}{\delta \mathrm{C}_{\mathrm{h}}}$ where $\mathrm{C}_{\mathrm{h}}$ is some parameter that affects the growth rate. This partial derivative can be thought of as a change in growth rate of species due to a change in carrying capacity of species. Changes in growth rate will in turn affect population size of species $i\left(\frac{\delta \mathrm{N}_{i}}{\delta \mathrm{C}_{\mathrm{h}}}\right)$ in the fol lowing way if the population is near equilibrium (Levins, 1975):

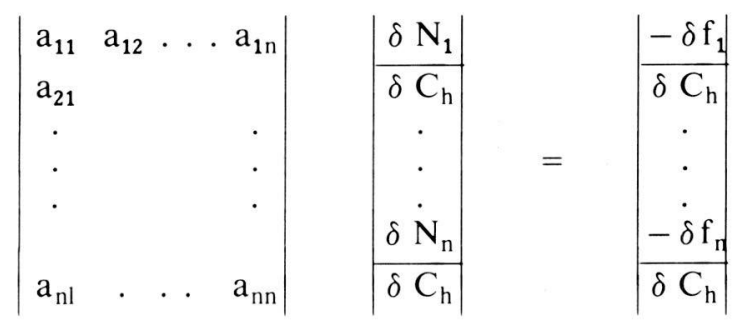

where $a_{i j}$ is the effect of species $\mathrm{j}$ on species $\mathrm{i}$. For the standard competition equations [1], 


$$
\mathrm{a}_{\mathrm{ij}}=\frac{-\mathrm{r}_{\mathrm{i}} \hat{\mathrm{N}}_{\mathrm{i}}}{\mathrm{K}_{\mathrm{i}}} \alpha_{\mathrm{ij}}
$$

The unknowns, i.e., the effect of perturbations $\left(\delta \mathrm{f}_{\mathrm{i}} / \delta \mathrm{C}_{\mathrm{h}}\right)$ on the population sizes, can be found by inverting the matrix in equation [7]. For three competitors:

$\left|\begin{array}{l}\frac{\delta \mathrm{N}_{1}}{\delta \mathrm{C}_{\mathrm{h}}} \\ \frac{\delta \mathrm{N}_{2}}{\delta \mathrm{C}_{\mathrm{h}}} \\ \frac{\delta \mathrm{N}_{3}}{\delta \mathrm{C}_{\mathrm{h}}}\end{array}\right|=\frac{1}{|\mathrm{~A}|}\left|\begin{array}{lll}\left(\mathrm{a}_{22} \mathrm{a}_{33}-\mathrm{a}_{23} \mathrm{a}_{32}\right) & \left(-\mathrm{a}_{33} \mathrm{a}_{12}+\mathrm{a}_{32} \mathrm{a}_{13}\right) & \left(-\mathrm{a}_{22} \mathrm{a}_{13}+\mathrm{a}_{12} \mathrm{a}_{23}\right) \\ \left(-\mathrm{a}_{21} \mathrm{a}_{33}+\mathrm{a}_{23} \mathrm{a}_{31}\right) & \left(\mathrm{a}_{11} \mathrm{a}_{33}-\mathrm{a}_{13} \mathrm{a}_{31}\right) & \left(-\mathrm{a}_{11} \mathrm{a}_{23}+\mathrm{a}_{13} \mathrm{a}_{21}\right) \\ \left(-\mathrm{a}_{22} \mathrm{a}_{31}+\mathrm{a}_{21} \mathrm{a}_{32}\right) & \left(-\mathrm{a}_{11} \mathrm{a}_{32}+\mathrm{a}_{12} \mathrm{a}_{31}\right)\left(\mathrm{a}_{11} \mathrm{a}_{22}-\mathrm{a}_{12} \mathrm{a}_{21}\right)\end{array}\right|\left|\begin{array}{l}-\delta \mathrm{f}_{1} \\ \frac{\delta \mathrm{C}_{\mathrm{h}}}{-\delta \mathrm{f}_{2}} \\ \frac{\delta \mathrm{C}_{\mathrm{h}}}{-\delta \mathrm{f}_{3}} \\ \frac{\delta \mathrm{C}_{\mathrm{h}}}{\mid}\end{array}\right|$

where $|\mathbf{A}|$ is the determinant of the matrix of inter action coefficients $a_{i j}$. Each off-diagonal term $\left(a^{\prime}{ }_{i j}\right)$ is the difference between the direct and indirect effect for species $j$ on species $i$ (see Levine, 1976). Each diagonal term $\left(a^{\prime}{ }_{i i}\right)$ is the determinant of the subcommunity formed by deleting species i. Each element $a^{\prime}{ }_{i j}$ measures the effect of a change in carrying capacity of species $j$ on the population size of species i.

Correlations can be predicted in the following way. A change in $\mathrm{K}_{\mathrm{i}}$ (or any parameter affecting species i directly) results in changes in population sizes of all species- -these are given in column i. The expected correlation between two species due to changes in $\mathrm{K}_{\mathrm{i}}$ in the community can be found by comparing signs of the two appropriate terms in column $\mathrm{i}$.

A concrete example should clarify this. In Gallohan Cave No. 1 and Gallohan Cave No. 2 three species compete, and their competition coefficients are:

\begin{tabular}{l|lll|} 
Crangonyx antennatus & 1 & 1.0 & 1.3 \\
Caecidotea recurvata & 0.3 & 1 & 1.3 \\
Lirceus usdagalun & 1.2 & 0.5 & 1
\end{tabular} \mid

Since $r_{i}, N_{i}$, and $K_{i}$ are all positive numbers, the sign of $a_{i j}$ depends only on the competition coefficients $\alpha_{\mathrm{ij}}$. Following the recipe in equation [9], the elements $\mathrm{a}_{\mathrm{ij}}$ have the following signs:

Change in $\mathrm{K}$ of:

C.a. C.r. L.u.

\begin{tabular}{ll|lll} 
Effect on & C.a. & + & - & 0 \\
Population Size & C.r. & + & - & - \\
of: & L.u. & - & + & +
\end{tabular}


If only the carrying capacity of one species, say Lirceus usdagalun, is varied $\left(\frac{\delta \mathrm{f}_{3}}{\delta \mathrm{C}_{\mathrm{h}}} \neq 0\right)$, then expected correlations would depend only on column 3 ,

since $\delta \mathrm{f}_{1} / \delta \mathrm{C}_{\mathrm{h}}$ and $\delta \mathrm{f}_{2} / \delta \mathrm{C}_{\mathrm{h}}$ are zero. However the carrying capacities of all species are likely to vary, and so correlation between species $\mathrm{i}$ and species $\mathrm{j}$ depends on all elements in row $\mathrm{i}$ and $\mathrm{j}$. In particular, we expect a positive correlation between two species $i$ and $j$ when the product of the elements $a_{i k} \times a_{j k}$ is zero or has the same sign for each value of $k$, i.e., for the entire row. Thus $C$. antennatus and $C$. recurvata should be positively correlated. If $\mathrm{a}_{\mathrm{ik}}$ and $\mathrm{a}_{\mathrm{jk}}$ have the same sign for the entire row (i.e., for all k) then there should be a negative correlation. Thus L. usdagalun should be negatively correlated with both $C$. antennatus and $C$. recurvata. If for some k's $\mathrm{a}_{\mathrm{ik}}$ times $\mathrm{a}_{\mathrm{jk}}$ is positive and negative for others, no prediction is possible unless the relative magnitude of the initial fluctuations is known.

The predictions about correlations depend critically on the signs of all elements $a_{i j}$. Therefore, Levine's (1976) procedure of dividing $a^{\prime}{ }_{i j}$ by $a^{\prime}{ }_{i i}$ to normalize the matrix may produce confusion. Since, ${ }^{\prime}{ }_{i i}$ can be negative (see $a_{22}$ above), row signs will be changed which would result in the wrong prediction about correlation. Note that if $a^{\prime}{ }_{i i}$ is negative, the sub-community formed by deleting species $i$ is unstable. Such unstable sub-communities may be common for competitors showing interference competition.

Similar predictions can be made for the three species in Court Street Cave, although accurate quantitative measurements are not available. The derivation of the predictions is given in Appendix 2 and summarized in the following table of signs for equation [9]:

\section{Pseudobaicalasellus holsingeri}

Stygobromus emarginatus

\section{Stygobromus spinatus}

$$
\left|\begin{array}{lll}
+ & - & - \\
- & + & + \\
- & + & +
\end{array}\right|
$$

Thus $S$. emarginatus and $S$. spinatus should be positively correlated and both should be negatively correlated with $P$. holsingeri.

In contrast with correlation coefficients, all partial correlations of competitors should be negative. This is because of the close correspondence between the definition of partial correlation and the definition of the competition coefficients (see Seifert and Seifert, 1976). Both essentially measure the effect (or correlation) of species $j$ on species $i$ with all other variables (i.e., population sizes of the other species) held constant.

Using Dickson's data for Spangler Cave and Gallohan Cave No. 2 (Dickson, 1976), Estes' unpublished data on Gallohan Cave No. 1, and my data on Court Street Cave, observed correlations and partial correlations can be compared with predictions (Table 3).

Of the 19 predictions about the signs of correlations and partial correlations, 16 are in agreement with the signs of the calculated values. This level of 
agreement would be attained on a chance basis with a probability of only 0.002 (Sign Test). In addition, five of these correlations were statistically significant (Table 3). Especially interesting is the complete agreement of observed and predicted correlations and partial correlations for Gallohan Cave No. 2. The time period of sampling in Gallohan No. 2 covers the period of the invasion of L. usdagalun (Dickson, 1976), a time of intense competition, but when the population are far from equilibrium. This suggests that the linear models used may hold far from equilibrium.

The interaction between Crangonyx antennatus and Caecidotea recurva-

Table 3. Comparison of observed and predicted correlations and partial correlations of species abundance through time.

\begin{tabular}{|c|c|c|c|c|c|c|}
\hline \multirow[b]{2}{*}{ CAVE SPECIES PAIR } & \multicolumn{3}{|c|}{ PARTIAL CORRELATION } & \multicolumn{3}{|c|}{ CORRELATION } \\
\hline & Predicted & Observed & $\mathbf{P}$ & Predicted & Observed & $\mathbf{P}$ \\
\hline $\begin{array}{l}\text { Spangler: } \\
\text { C. recurvata } \\
\text { C. antennatus }\end{array}$ & - & $-0.34^{*}$ & N.S. & - & $-0.34^{*}$ & N.S. \\
\hline $\begin{array}{l}\text { Gallohan No. 2: } \\
\text { C. recurvata } \\
\text { C. antennatus }\end{array}$ & - & -0.99 & $>0.99$ & + & +0.28 & N.S. \\
\hline $\begin{array}{l}\text { Gallohan No. 2: } \\
\text { C. antennatus } \\
\text { L. usdagalun }\end{array}$ & - & -0.99 & $>0.99$ & - & -0.57 & N.S. \\
\hline $\begin{array}{l}\text { Gallohan No. } 2: \\
\text { C. recurvata } \\
\text { L. usdagalun }\end{array}$ & - & -0.99 & $>0.99$ & - & -0.95 & $>0.95$ \\
\hline $\begin{array}{l}\text { Gallohan No. 1: } \\
\text { C. recurvata } \\
\text { C. antennatus }\end{array}$ & - & +0.30 & N.S. & + & +0.11 & N.S. \\
\hline $\begin{array}{l}\text { Gallohan No. 1: } \\
\text { C. antennatus } \\
\text { L. usdagalun }\end{array}$ & - & -0.82 & N.S. & - & -0.82 & $>0.95$ \\
\hline $\begin{array}{l}\text { Gallohan No. 1: } \\
\text { C. recurvata } \\
\text { L. usdagalun }\end{array}$ & - & +0.05 & N.S. & - & +0.07 & N.S. \\
\hline $\begin{array}{l}\text { Court Street: } \\
P . \text { holsingeri } \\
\text { S. emarginatus }\end{array}$ & - & -0.36 & N.S. & - & -0.38 & N.S. \\
\hline $\begin{array}{l}\text { Court Street: } \\
P . \text { holsingeri } \\
\text { S. spinatus }\end{array}$ & - & -0.51 & N.S. & - & -0.48 & N.S. \\
\hline $\begin{array}{l}\text { Court Street: } \\
\text { S. emarginatus } \\
\text { S. spinatus }\end{array}$ & - & -0.01 & N.S. & + & +0.19 & N.S. \\
\hline
\end{tabular}

* Correlation and partial correlation are identical because there are only two species in the community. 
ta epitomizes the importance of indirect effects in the organization of communities. When no other competitors are present (Spangler Cave), the two species are negatively correlated. When a third competitor is present (Gallohan Cave No. 1 and Gallohan Cave No. 2), the two species are positively correlated.

\section{DISCUSSION}

The ratio of the sum of individual species' variances to the variance of total abundance of the species is a convenient way to summarize competitive effects in a community. However, available data (Table 2) indicate that this ratio may be unlikely to be large enought to be statistically significant unless very large numbers of samples are taken. Furthermore, possible correlations among carrying capacities ( $\mathrm{K}_{\mathrm{i}}$ 's) of the different species can result in the above variance ratios being less than one, even though the species are competing. This has apparently happened in the community in Gallohan Cave No. 1. So, for real communities this ratio is unlikely to be of great value.

The results of the correlation and partial correlation analysis are much more convincing. The high level of agreement between the observed and expected correlations and partial correlations (Table 3) provides strong support for the hypothesis that linearized models of competition are sufficient to describe temporal fluctuations in species' abundance. It is also clear that competitors can be positively correlated- -not only in theory but in actuality (Table 3).

The potential for positive correlations among competitors has important implications for perturbation experiments. It is claimed (e.g., Connell 1975) that perturbation experiments are the only clear way to demonstrate interspecific competition. But the possibility of positive correlation among competitors means that increasing one species may actually increase another competing species, leading one to conclude that the competitor was actually a mutualist or the prey of the other species. Thus perturbation experiments are as difficult to interpret as the indisturbed temporal patterns.

It should be remembered that the hypotheses discussed in this paper are based on linear models. There has been a feeling among many ecologists that the usual models of competition (equation 1) do not contain sufficient complexity to explain interactions in the real world (e.g. Ayala et al., 1973). However, much of the apparent simplicity of standard competition models is due to considering only two competing species. The addition of just one additional species allows for qualitatively new results, such as positive correlations among competitors. Still other possible patterns of fluctuation of three competing species are not possible when two species are present (May and Leonard, 1975). Communities with small numbers of interacting species, such as cave stream communities and desert ant communities (Davidson, 1980), should play an important role in testing species interaction theory. 


\section{ACKNOWLEDGMENTS}

Discussions with Richard Levins and Diane Davidson provided a great many clarifications and ideas. Gary Dickson and James Estes generously provided data from Virginia caves. John Holsinger assisted with field work.

\section{RÉSUMÉ}

Sur la base d'un travail théorique de Robert May et Richard Levins, deux hypothèses sur les fluctuations dans le temps de l'abondance d'espèces en compétition ont été émises. Les données relatives aux espèces d'Isopodes et d'Amphipodes appartenant aux communautés biologiques de quatre cours d'eau souterrains de Virginie et Virginie Occidentale ont été utilisées pour tester ces hypothèses.

Premièrement: la variance de l'abondance totale devrait être inférieure à la somme des variances de l'abondance de chaque espèce prise isolément. Dans trois des quatre communautés étudiées, l'hypothèse s'est vérifiée, mais en aucun cas d'une manière statistiquement significative. L'existence de corrélations positives entre les capacités biotiques propres à chacune des espèces en compétition pourrait expliquer la médiocre coïncidence entre prédictions et observations.

Deuxièment, le signe de 19 corrélations ou corrélations partielles concernant l'abondance des espèces a été prévu théoriquement, en fonction de l'amplitude relative des effets directs ou indirects de la compétition. Parmi ces prévisions, 16 ont été confirmées par les observations, dont 5 d'une manière statistiquement significative. La découverte la plus intéressante réside dans le fait que des corrélations positives peuvent exister entre des espèces compétitrices.

\section{LITERATURE}

AYALA, F.J., M.E., GILPIN, and J.G. EHRENFELD 1973. Competition between species: theoretical models and experimental tests. Theoret. Popul. Biol. 4: 331-356.

BOWMAN, T.E. 1975. Three new troglobitic asellids from western North America (Crustacea: Isopoda: Asellidae). Int.J.Speleol. 7:327-338.

CONNELL, J.H. 1975. Some mechanisms producing structure in natural communities, in Ecology and evolution of communities, CODY M.L. and J.M. DIAMOND Eds., Harvard Univ. Press, Cambridge, Mass.: 460-490.

CULVER, D.C. 1970. Analysis of simple cave communities: niche separation and species packing. Ecology 51:949-958.

CULVER, D.C. 1971. Analysis of simple cave communities. III. Control of abundance. Am. Midl. Nat. 85:173-187.

CULVER, D.C. 1973. Competition in spatially heterogeneous systems: an analysis of simple cave communities. Ecology 54:102-110.

CULVER, D.C. 1976. The evolution of aquatic cave communities. Am. Nat. 110:945-957.

DAVIDSON, D.W. 1980. Some consequences of diffuse competition in a desert ant community. Am. Nat. 116:92-105.

DICKSON, G.W. 1976. Variation in the ecology, morphology and behavior of the troglobitic amphipod crustacean Crangonyx antennatus Packard (Crangonychidae) from different habitats. Master's Thesis, Old Dominion University, Norfolk, Va.

GANTMACHER, F.R. 1959. Applications of the theory of matrices. Wiley Interscience, New York, N.Y.

GLEDHILL, T. 1977. Numerical fluctuations of four species of subterranean amphipods during a five year period. Crustaceana Suppl. 4:144-152.

HOLSINGER, J.R., R. BAROODY, and D. CULVER 1976. The invertebrate cave fauna of West Virginia. West Virginia Speleological Survey Bulletin 7, 82 p.

LEVINE, S.H. 1976. Competitive interactions in ecosystems. Am. Nat. 110:903-910.

LEVINS, R. 1975. Evolution in communities near equilibrium, in: Ecology and evolution of communities, CODY M.L. and J.M. DIAMOND eds., Harvard Univ. Press, Cambridge, Mass. 
MAY, R.M. 1973. Stability and complexity in model ecosystems. Princeton Univ. Press, Princeton, N.J.

MAY, R.M. 1974a. Ecosystem patterns in randomly fluctuating environments, in: Progress in theoretical biology, volume 3, ROSEN R. and F.M. SNELL eds., Academic Press, New York, N.Y.

MAY, R.M. 1974b. How many species: some mathematical aspects of the dynamics of populations, in: Lectures on mathematics in the life sciences 6: some mathematical questions in biology V, COWAN J.D. ed., Amer. Math. Soc., Providence, R.I. .

MAY, R.M. and W.J. LEONARD. 1975. Nonlinear aspects of competition between three species. SIAM J. Appl. Math. 29:243-253.

NEILL, W.E. 1974. The community matrix and the interdependence of the competition coefficients. Am. Nat. 108:399-408.

POULSON, T.L., and W.B. WHITE. 1969. The cave environment. Science 165:971-981.

ROUGHGARDEN, J. 1975. Population dynamics in a stochastic environment: spectral theory for the linearized $\mathrm{N}$-species Lotka-Volterra competition equations. Theoret. Popul. Biol. 7:1-12.

SEARLE, S.R. 1966. Matrix algebra for the biological sciences. J. Wiley and Sons, New York, N.Y.

SEIFERT, R.P., and F.H. SEIFERT. 1976. A community matrix analysis of Heliconia insect communities. Am. Nat. 110:461-483.

SMALE, S. 1976. On the differential equations of species in competition. J. Math. Biol. 3:5-7.

STROBECK, C. 1973. N species competition. Ecology 54:650-654.

\section{APPENDIX 1}

1. Gallohan Cave No. 1 (unpublished data of James Estes)

Number of individuals per $\mathrm{ft}^{2}\left(0.09 \mathrm{~m}^{2}\right)$

$\begin{array}{lccc}\text { Date } & \text { L. usdagalun } & \text { C. recurvata } & \text { C. antennatus } \\ \mathrm{XI} / 74 & 8.78 & 3.61 & 0.44 \\ \mathrm{II} / 75 & 6.33 & 2.00 & 0.50 \\ \mathrm{VI} / 75 & 5.94 & 0.72 & 0.61 \\ \text { VIII/75 } & 5.67 & 4.50 & 0.67 \\ \mathrm{XI} / 75 & 8.61 & 1.94 & 0.50\end{array}$

2. Court Street Cave

Number of individuals per $\mathrm{ft}^{2}\left(0.09 \mathrm{~m}^{2}\right)$

$\begin{array}{lccc}\text { Date } & P . \text { holsingeri } & \text { S. emarginatus } & \text { S. spinatus } \\ \text { VI/67 } & 0.11 & 0.67 & 2.56 \\ \text { VIII/67 } & 0.11 & 0.44 & 1.78 \\ \text { XI/67 } & 0.43 & 0.43 & 1.00 \\ \text { II/68 } & 0.56 & 0.89 & 1.33 \\ \text { VI/68 } & 0.89 & 0.22 & 1.44 \\ \text { V/68 } & 0.14 & 0.71 & 1.57 \\ \text { IV/69 } & 0.11 & 0.56 & 1.56\end{array}$


3. Gallohan Cave No. 2 (Dickson, 1976)

Number of individuals $/ \mathrm{m}^{2}$

Date

VIII $/ 74$

$\mathrm{XI} / 74$

II $/ 75$

VI/75
C. antennatus

17

5

4

C. recurvata

L. usdagalun

4. Spangler Cave (Dickson, 1976)

Number of individuals $/ \mathrm{m}^{2}$

$\begin{array}{lcc}\text { Date } & \text { C. antennatus } & \text { C. recurvat } \\ \text { VIII } / 74 & 125 & 23 \\ \mathrm{XI} / 74 & 23 & 25 \\ \mathrm{II} / 75 & 18 & 20 \\ \mathrm{VI} / 75 & 15 & 40\end{array}$

\section{APPENDIX 2}

The signs of the terms $\mathrm{a}_{\mathrm{ij}}$ in equation [9] depend on:

$$
\left|\begin{array}{lll}
\left(1-\alpha_{23} \alpha_{32}\right) & \left(-\alpha_{12}+\alpha_{32} \alpha_{13}\right) & \left(-\alpha_{13}+\alpha_{12} \alpha_{23}\right) \\
\left(-\alpha_{21}+\alpha_{23} \alpha_{31}\right) & \left(1-\alpha_{13} \alpha_{31}\right) & \left(-\alpha_{23}+\alpha_{13} \alpha_{21}\right) \\
\left(-\alpha_{31}+\alpha_{21} \alpha_{32}\right) & \left(-\alpha_{32}+\alpha_{12} \alpha_{31}\right) & \left(1-\alpha_{12} \alpha_{21}\right)
\end{array}\right|
$$

The order of species is (1) Pseudobaicalasellus holsingeri, (2) Stýgobromus emarginatus, and (3) $S$. spinatus. Since all sub-communities of two species occur in isolation (Holsinger et al., 1976), all these sub-communities must be stable, and all diagonal elements of (Al) are positive.

$$
\left|\begin{array}{lll}
+ & ? & ? \\
? & + & ? \\
? & ? & +
\end{array}\right|
$$

Competition between $S$. emarginatus and $S$. spinatus is much less than for any other pair, so $\alpha_{23}$ and $\alpha_{32}$ are much less than the other $\alpha$ 's. Then the expected signs of the elements of (A1) are:

$$
\left|\begin{array}{ccc}
+ & - & - \\
- & + & + \\
- & + & +
\end{array}\right|
$$

which is the result given in [12]. 


\title{
Distribution and Habitat Diversity of Subterranean Amphipods in the Rocky Mountains of Colorado, U.S.A.
}

\author{
James V. Ward* \\ and John R. Holsinger**
}

\begin{abstract}
SUMMARY
Subterranean amphipods have been collected from 35 locations on the eastern and western slopes of the Continental Divide in Colorado. All belong to the exclusively subterranean genus Stygobromus. Five species have been identified, two of which are undescribed. Specimens have been collected from (a) the hyporheic zone of rivers, (b) interrupted streams, (c) springs, and (d) seeps at elevations from 1597-2134 m a.s.l. Stygobromus occurs in several habitat types in interrupted drainage basins including sources, seeps, and isolated pools containing leaf detritus. All habitats contained waters which were cool to cold with dissolved oxygen values ranging from 4.3 $\mathrm{ppm}$ to fully saturated. Most waters exhibited soft or medium hardness, although one spring containing an undescribed species of Stygobromus had very hard waters $\left(203 \mathrm{ppm}\right.$ bound $\mathrm{CO}_{2}$ ) and was mildly saline ( $913 \mathrm{mg} / 1 \mathrm{TDS})$. There is evidence that the subterranean amphipods are phreatobites which, only under special conditions, establish relatively permanent populations in epigean habitats. Although little is known regarding ecology, zoogeography, or even taxonomy of the subterranean fauna of this region, stygobromid amphipods from the Cordilleran of western North America are apparently represented by fewer well differentiated species per unit area than their congeners from the geologically older Appalachian region of eastern North America where numerous species are found in caves.
\end{abstract}

\section{INTRODUCTION}

The great diversity of aquatic habitats in the western United States is associated with dramatic shifts in climate, geochemistry, and topography, often over relatively short distances (Pennak, 1958). Stygobromus, the only subterranean amphipod genus occurring in the far western United States, has been previously reported from caves, lava tubes, wells, springs, and the profundal zone of a Pleistocene relict lake (Holsinger, 1974). Holsinger emphasized the highly insular distribution of subterranean species and predicted the discovery of a new species of Stygobromus in the rugged mountainous country of this region.

Recent descriptions of three Cordilleran species (Ward, 1977) provided the first records of subterranean amphipods in Colorado and brought to 21

* Department of Zoology and Entomology Colorado State University Fort Collins, Colorado 80523 U.S.A. .

** Department of Biological Sciences Old Dominion University Norfolk, Virginia 23508 U.S.A. . 
the total number of western species. Further studies in Colorado have resulted in the discovery of two additional species, which will be described elsewhere (Holsinger \& Ward, in preparation), and extensions in range and habitat type for the recently described $S$. holsingeri Ward.

It is the purpose of this paper (1) to describe the recorded distribution of subterranean amphipods in Colorado, and (2) to describe the variety of habitats, some of which are somewhat unusual, which the various species occupy.

\section{GEOGRAPHICAL DISTRIBUTION}

Since 1974, numerous stygobromid amphipods have been collected from three general areas of Colorado (Fig. 1). Stygobromus coloradensis Ward and $S$. pennaki Ward, originally reported from the North Fork of the South Platte River (Ward, 1977), have also been found to occur sympatrically in the South Platte River proper.

Sixteen specimens of Stygobromus (undescribed species B) were collected from a saline spring at $19851 \mathrm{~m}$ elevation in an area of sedimentary rock deposited by ancient Lake Uinta. This location in the Upper Colorado River Basin is the only known occurrence of subterranean amphipods west of the Continental Divide in Colorado.

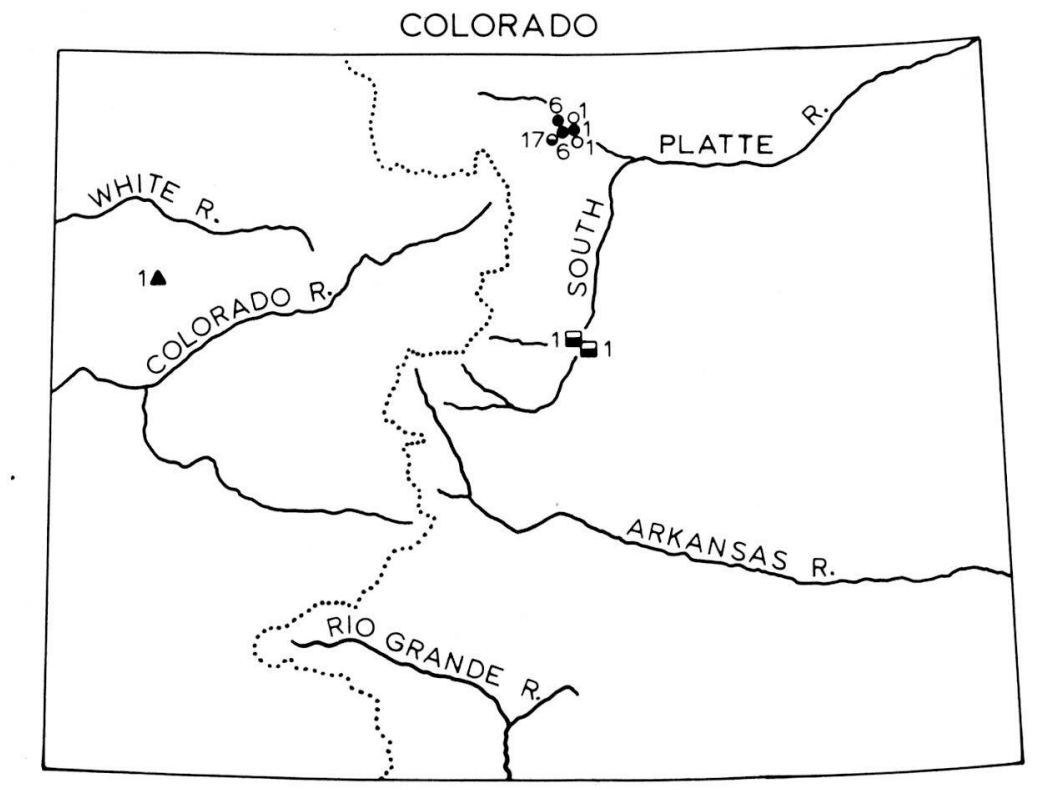

Fig. 1. Distribution of Stygobromus in Colorado, U.S.A. Species are indicated as follows: $S$. coloradensis, $\square$ S. pennaki, $\bullet S$. holsingeri, $\bigcirc$ undescribed sp. A, $\Delta$ undescribed sp. B. Arabic numerals indicate the number of locations from which specimens have been collected. Dotted line is the Continental Divide. 
Well over 600 specimens of two species of Stygobromus have been collected from several habitat types at numerous locations (1597-2134 $\mathrm{m}$ a.s.l.) in the area surrounding Horsetooth Reservoir in northern Colorado (Fig. 2). The seep on the hogback ridge on the east side of the reservoir is the typelocality of $S$. holsingeri, which has subsequently been found in relatively inaccessible canyons on the next east-facing slope (Devil Gulch and Soldier Canyon), and in an unnamed drainage system on the east-facing slope of

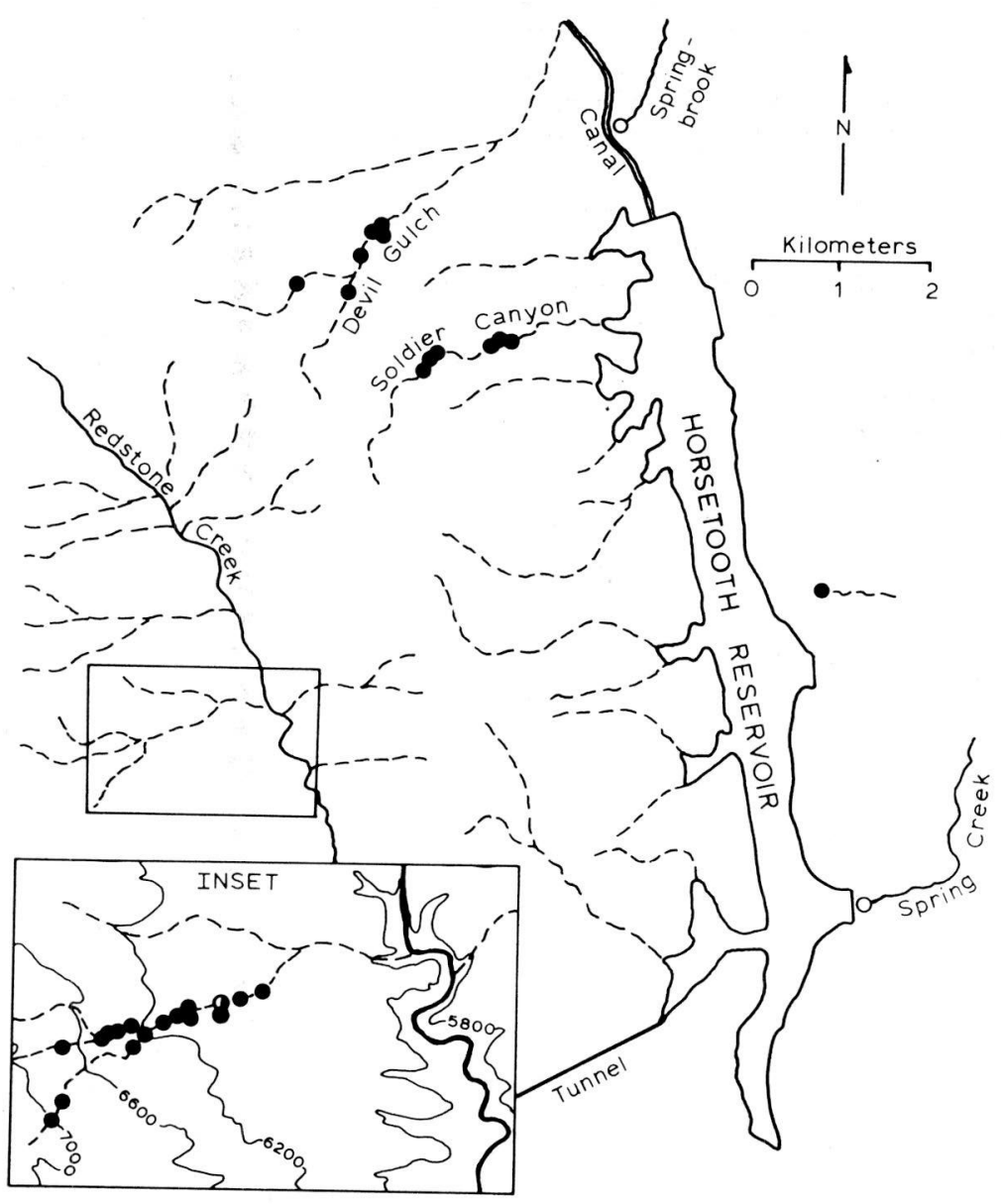

Fig. 2. Distribution of Stygobromus in springs, seeps, and interrupted stream systems (dashed lines) in the civinity of Horsetooth Reservoir in northern Colorado. Symbols as in figure 1. Contour lines, from a U.S. Geological Survey map, are shown in the inset for 5800 feet $(1768 \mathrm{~m}), 6200$ feet $(1890 \mathrm{~m}), 6600$ feet $(2012 \mathrm{~m})$, and 7000 feet $(2134 \mathrm{~m})$ elevations. 
Redstone Creek (Fig. 2 inset). Undescribed species A occurs sympatrically with $S$. holsingeri at a site in the unnamed drainage basin. Conversely, while over 60 specimens of Stygobromus have been collected from springs at the north and south ends of Horsetooth Reservoir, all individuals have been identified as undescribed species A. A one-year study of the profundal benthos of Horsetooth Reservoir (Edmonds \& Ward, 1979) failed to yield amphipods.

\section{HABITAT DIVERSITY}

River hyporheic. Initial collections of $S$. coloradensis and $S$. pennaki were from the North Fork just above the confluence of the South Platte River (Ward, 1977). Additional specimens have been taken from that location, and both species have since been collected in the South Platte River above the confluence. The two foothills locations (1855 $\mathrm{m}$ a.s.l.) provide somewhat different environmental conditions despite their contiguity (Ward, 1976). North Fork water is softer ( 15 vs 36 ppm bound $\mathrm{CO}_{2}$ ), with lower values of total dissolved solids (67.6 vs $191.5 \mathrm{mg} / 1)$. The North Fork has well-developed riparian vegetation with large inputs of allochthonous detritus, whereas the South Platte River is primarily autotrophic with large standing crops of epilithic algae. However, thermal conditions were similar at both locations and dissolved oxygen values were always near saturation. Stygobromids were collected immediately upstream from small islands at both river locations. Although there was rubble on the substrate surface, the amphipods occur in the interstices of granitic sand and gravel of the hyporheic zone (Table 1). In April of 1977, the stygobromid density in the top $30 \mathrm{~cm}$ of substrate was estimated to be 511 amphipods $/ \mathrm{m}^{2}$ at the South Platte River location and $436 / \mathrm{m}^{2}$ for the North Fork. Although amphipods (e.g., Niphargus) are widespread in hyporheic habitats in Europe, no other subterranean amphipods have been reported from the hyporheic zone in North America.

Saline spring. In May 1977, 16 specimens of an undescribed species of Stygobromus were collected from a small saline spring which emerges from the base of a hill in western Colorado (Fig. 1). Water temperature at the time of collection was $8^{\circ} \mathrm{C}$; the water was very hard $\left(203 \mathrm{ppm}\right.$ bound $\left.\mathrm{CO}_{2}\right)$, mildly saline (913 mg/1 TDS), and athalassohaline. Subterranean amphipods have not been previously reported from saline springs in North America. The amphipods are apparently phreatobites since specimens were restricted to the source and, in fact, were found only by digging deep into the source while holding a net downstream. Substrate consisted of flat rubble and gravel chips composed of shale, marlstone, and sandstone.

Northern Colorado habitats. Stygobromids have been collected from springbrook, seep, and interrupted stream habitats in northern Colorado (Table 1, Fig. 2). The seep to the east of Horsetooth Reservoir is completely isolated from other surface waters. It flows only periodically and then for only a few meters. The bedrock is sandstone with some conglomerate. The am- 
Table 1. Habitat type and dominant substrate for Stygobromus in Colorado. (See text for physicochemical habitat characteristics).

\begin{tabular}{|c|c|c|c|c|c|}
\hline \multirow[b]{2}{*}{ Species } & \multirow{2}{*}{$\begin{array}{l}\text { General } \\
\text { habitat }\end{array}$} & \multicolumn{3}{|c|}{ Specific Habitat* } & $\begin{array}{l}\text { Dominant } \\
\text { Substrate** }\end{array}$ \\
\hline & & Pool & Source & Hyporheic & C D M R G S \\
\hline coloradensis & rivers & - & - & 2 & $\mathrm{Xx}$ \\
\hline pennaki & rivers & - & - & 2 & $\mathrm{x} x$ \\
\hline \multirow[t]{2}{*}{ holsingeri } & seep & - & 1 & - & $\mathrm{x}$ \\
\hline & streams & 14 & 15 & - & $\mathrm{X} \times \mathrm{X} \times \mathrm{X} \times$ \\
\hline \multirow[t]{2}{*}{ undescr.sp.A. } & $\begin{array}{l}\text { springbrooks } \\
\text { interrupted }\end{array}$ & - & 2 & - & $\mathrm{X} \times \mathrm{X}$ \\
\hline & stream & - & 1 & - & $\mathrm{X} \times \mathrm{X}$ \\
\hline undescr.sp.B. & saline spring & - & 1 & - & $\mathrm{XX}$ \\
\hline
\end{tabular}

* Numerals indicate number of locations

** $\mathrm{C}=$ conifer needles

$\mathrm{D}=$ deciduous leaves

$\mathbf{M}=$ mud and silt

$\mathrm{R}=$ rubble

$\mathrm{G}=$ gravel

$\mathrm{S}=$ sand

phipods were associated with masses of pine needles and cow pats at the source. The source temperature was $8^{\circ} \mathrm{C}$; pH was 6.0 .

Stygpbromids were collected from springbrooks at apposite ends of Horsetooth Reservoir (Fig. 2). An undescribed species was taken in watercress (Rorippa nasturtium-aquaticum) from the source of Spring Creek. Water temperature was $8^{\circ} \mathrm{C}$; ph was 7.3 . The substrate consists primarily of sand and gravel. During a one-year study of the springbrook north of Horsetooth Reservoir not a single stygobromid amphipod was collected, despite monthly sampling of several habitats near the source. Over two years after the completion of the study, 14 specimens of an undescribed species of Stygobromus were collected. Subsequent collecting has resulted in 40 additional specimens. All were taken under small rocks just at the source. A sampling station less than a meter away failed to yield a single amphipod during the year of study. Detailed data on physicochemical conditions, macrophytes, macroinvertebrates, and epilithic algae are presented in Ward and Dufford, 1979. Source temperatures varied from $8-10^{\circ} \mathrm{C}$ throughout the year. Annual means were as follows: $\mathrm{pH}, 7.7$; bound $\mathrm{CO}_{2}, 29.5 \mathrm{ppm}$; TDS, $116 \mathrm{mg} / 1$. The bedrock is primarily sandstone with some limestone.

Subterranean amphipods were collected from 29 locations in three interrupted drainage systems west of Horsetooth Reservoir. The most intensive work was conducted on the unnamed drainage across a small chain of mountains (Fig. 2 inset) where Stygobromus was collected from 17 locations (1817- 
$2134 \mathrm{~m}$ a.s.l.). Specimens were taken during all seasons, but were most abundant in late April and early May, the time of greatest surface flow. Even then the length of dry streambed exceeded that carrying surface water, although this varied greatly at different locations. Schist and gneiss compose the bedrock above about $1800 \mathrm{~m}$ elevation; a fine-grained red sandstone occurs in lower reaches.

While the following physical and chemical data apply specifically to the unnamed drainage confluent to Redstone Creek, all interrupted streams were generally similar. Water temperatures ranged from $5-9^{\circ} \mathrm{C}$ at locations from which Stygobromus was collected during April-May. Bound $\mathrm{CO}_{2}$ ranged from $16.5 \mathrm{ppm}$ at upper elevations to around $40 \mathrm{ppm}$ at downstream sites. Dissolved oxygen varied from 4.3 to $7.4 \mathrm{ppm}$. The $\mathrm{pH}$ was near neutrality at all locations. Total dissolved solids ranged from $50.4 \mathrm{mg} / 1$ at an upper site to 96.4 at a downstream location. Near the mouth, the temperature was $9.5^{\circ} \mathrm{C}$; pH was 7.6; bound $\mathrm{CO}_{2}$ was $66 \mathrm{ppm}$; TDS was $167.4 \mathrm{mg} / 1$. However, no subterranean amphipods were found in the lower reaches of sandstone beelrock despite otherwise seemingly suitable conditions. It is thought that the fine grain of the sandstone precludes interstitial forms since Stygobromus occurs at locations which have coarse-grained sedimentary rocks or have conglomerates mixed with sandstone.

Stygobromus occupied several habitat types in the interrupted drainage basins. Some sites were similar to rheocrene sources since water emerged with a good current and the substrate was composed of rubble and gravel. At other locations, the water seeped out more slowly and there was a finer substrate. Some of the latter formed pools which filled with conifer needles or deciduous leaves, forming the "biotope hypotelminorhéique" of Meŝtrov (1962). Some locations were isolated leaf-filled pools scarcely $30 \mathrm{~cm}$ across which, despite their apparently stagnant condition, had low but adequate dissolved oxygen concentration. Subterranean amphipods were not collected from sections in which surface flow continued more than a few meters.

\section{CONCLUSIONS}

By contrasting Colorado habitats from which Stygobromus have been collected with those from which subterranean amphipods are absent, the following generalizations are cautiously presented. It should be emphasized that Colorado has only recently been explored for subterranean amphipods, and many geographical areas have yet to be investigated.

It is thought that the Stygobromus collected in Colorado are phreatic forms which are accidentals in epigean habitats. Even the hyporheic habitat is considered to be part of the phreatic zone by some authors (e.g., Chappius, 1950). The restriction of Stygobromus to the source region of springbrooks supports this viewpoint. Only under special conditions, such as occur in certain interrupted streams, will relatively permanent populations be established in surface waters. If surface waters persist long enough for the establishment of a normal aquatic fauna, Stygobromus will be excluded or restricted to the 
immediate area of egress. If the bedrock is too close to the surface, or if the substrate is too fine, Stygobromus will be absent.

Certain orgnaisms commonly occur in samples containing Stygobromus. If ephemeropterans do occur, they are nearly always Baetis. The lumbricid Eiseniell tetraedra is a common associate, as are several tipulids and certain chironomids. Hesperophylax and hydroptilid trichopterans are also common associates, as are dytiscid and hydrophilid coleopterans. If plecopterans are present, they are usually nemourids, although two carnivorous stoneflies have been collected from Stygobromus habitats. Alloperla was common in the hyporheic zone of the North Fork and South Platte Rivers, but most specimens were early instars which are primarily detritivores. Mature nymphs of Isoperla patricia occurred deep within the saline spring source, an unusual habitat for a medium-sized carnivorous stonefly. Epigean amphipods are rarely present in habitats containing Stygobromus. Although Hyalella azteca was present in the springbrook north of Hossetooth Reservoir (Ward \& Dufford, 1979), not a single specimen was collected from the sampling substation near the source from which the undescribed Stygobromus was collected.

Stygobromid amphipods from the Cordilleran region of western North America are apparently represented by fewer well differentiated species per unit area than their congeners from the geologically older Appalachian region of eastern North America where numerous species are found in caves (see Holsinger, 1978). To date, the relatively few wet caves in Colorado have not been examined for aquatic organisms.

In Europe and the eastern United States, the subterranean fauna has been relatively well studied. In the western United States, however, many basic questions relating to predator-prey and competitive interactions, seasonal and diurnal migrations, zoogeography and phylogeny remain unanswered and provide fertile areas for future research.

\section{ACKNOWLEDGMENTS}

The authors wish to thank Dr. R.W. Pennak, University of Colorado, for critically reviewing the manuscript and Dr. G. Magniez, University of Dijon, for assistance with the French résumé.

\section{RÉSUMÉ}

Des Amphipodes souterrains ont été collectés en 35 endroits différents, répartis sur les versants Est et Ouest des Montagnes Rocheuses, au Colorado. Tous appartiennent au genre exclusivement souterrain Stygobromus. Sur les cinq espèces capturées, deux font l'objet d'une description. Les spécimens ont des origines variées: milieu interstitiel hyporhéique des rivières, résurgences de ruisseaux, sources et suintements temporaires, situés à des altitudes comprises entre 1597 et 2134 mètres. On trouve les Stygobromus dans plusieurs biotopes différents dans les bassins à écoulement interrompu: sources, ruissellements, mares isolées contenant des débris de feuilles. Dans tous les biotopes, les eaux sont fraîches ou froides et la teneur eu oxygène varie de 4,3 p.p.m. à la saturation totale. La dureté est moyenne ou faible pour la plupart des eaux, mais une source d'eau très dure (203 p.p.m. de $\mathrm{CO}_{2}$ lié) et légèrement saline $(913 \mathrm{mg} / 1$ de substances dissoutes) contient une espece non décrite de Stygobromus. Il paraît évident que les Amphipodes souterrains sont des phréatobies qui n'établissent des populations relativement permanentes dans 
les biotopes épigés que dans des conditions particulières. Bien que l'écologie, la zoogéographie et même la taxonomie de la faune souterraine de cette région soient encore peu connues, les Amphipodes Stygobromes de la Cordillère occidentale de l'Amérique du Nord semblent représentés, par unité de surface, par un moins grand nombre d'espèces que leurs congénères des Appalaches, à l'Est de l'Amérique du Nord, région géologiquement plus ancienne, où l'on trouve de nombreuses espèces dans les grottes.

\section{LITERATURE}

CHAPPIUS P.A. 1950. La récolte de la faune souterraine. Notes Biospéol. 5:7-35.

EDMONDS J.S., and J.V. WARD. 1979. Profundal benthos of a multibasin foothills reservoir in Colorado, U.S.A. Hydrobiologia 63:199-208.

HOLSINGER J.R. 1974. Systematics of the subterranean amphipod genus Stygobromus (Gammaridae), Part I: Species of the Western United States. Smithsonian Contrib. Zool. No. 160:1-63.

HOLSINGER J.R. 1978. Systematics of the subterranean amphipod genus Stygobromus (Crangonyctidae), Part II: Species of the Eastern United States. Smithsonian Contrib. Zool. No. 266:1-144.

MEŚTROV M. 1962. Un nouveau mileau aquatique souterrain: Le Biotope hypotelminorhéique. Comptes Rendus 254:2677-2679.

PENNAK R.W. 1958. Some problems of freshwater invertebrate distribution in the Westerti States, in: Zoogeography, HUBBS C.L., Ed., Amer. Assoc. Adv. Sci., Washington, D.C.: $223-230$.

WARD J.V. 1976. Comparative limnology of differentially regulated sections of a Colorado mountain river. Arch. Hydrobiol. 78:319-342.

WARD J.V. 1977. First records of subterranean amphipods from Colorado with descriptions of three new species of Stygobromus (Crangonyctidae). Trans. Am. Microsc. Soc. 96:452466.

WARD J.V., and R.G. DUFFORD. 1979. Longitudinal and seasonal distribution of macroinvertebrates and epilithic algae in a Colorado springbrookpond system. Arch. Hydrobiol. 86:284-321. 


\title{
Biogeographical and Paleobiogeographical Problems in Stenasellids (Crustacea Isopoda Asellota of Underground Waters)
}

\author{
Guy J. Magniez (*)
}

\begin{abstract}
SUMMARY
Considering their systematic isolation among present Asellota, their strong burrowing behavior, their aptitude for interstitial life and their wide north-tropical present distribution, the history of Stenasellid Crustaceans seems to be marked by the antiquitiy of their settlements in continental groundwaters (Middle Cretaceous period?) and a long stage of life in phreatic waters on permanently emerged paleotropical continents during the Cenozoic Era. The resemblance between some forms of the Guinean shield and Mexico sets the problem of the anteriority of their continental conquest to South Atlantic drift. The repartition of Mediterranean European forms appears as a consequence of paleogeographical changes on Tertiary Times. The distribution of continental European forms has been marked by Quaternary climatic alterations: severe curtailment of settlements, endemicity in Glacial periods but wide Holocene expansion for the forms adapted to new climatic conditions.
\end{abstract}

Captured in the subterranean river of Padirac (SW France), Stenasellus virei Dollfus, 1897 was first considered as a relict isopod (Viré, 1902). In 1938, however, nine Stenasellus species were known from caves and groundwaters of Spain, France, Italy, Yougoslavia, Hungary, and Bulgaria (Husson, 1957). So, the genus was considered as a characteristic of the Southern European troglobitic fauna. Since 1938, 17 Stenasellids have been discovered in the subterianean waters of Africa, 2 in Southern Asia and some 5 in the New World (fig. 1), and the Stenasellids are considered as an independent family, anciently isolated from all other present Asellota stocks (Arcangeli, 1938; Magniez, 1974-75). This group widely colonizes the underground waters of several North-tropical regions of the world with an accessory settlement in Mediterranean Europe.

Some observations made on St. virei pointed up that free-water biotopes (clayey pools, gours, underground rivers) are accessory biotopes. The own nature of stenasellids is phreatobitic as they are able to live in the interstitial water of coarse alluvium. The more important populations live in alluvial valleys and in the gravels of the bed of some rivers. Furthermore, their burrowing behavior is well developed; in clayey alluvium or eluvium they can dig their nets of galleries, more and more ramified, inside which all their life cycle may occur. The young are able to burrow in clay as soon as they leave the 


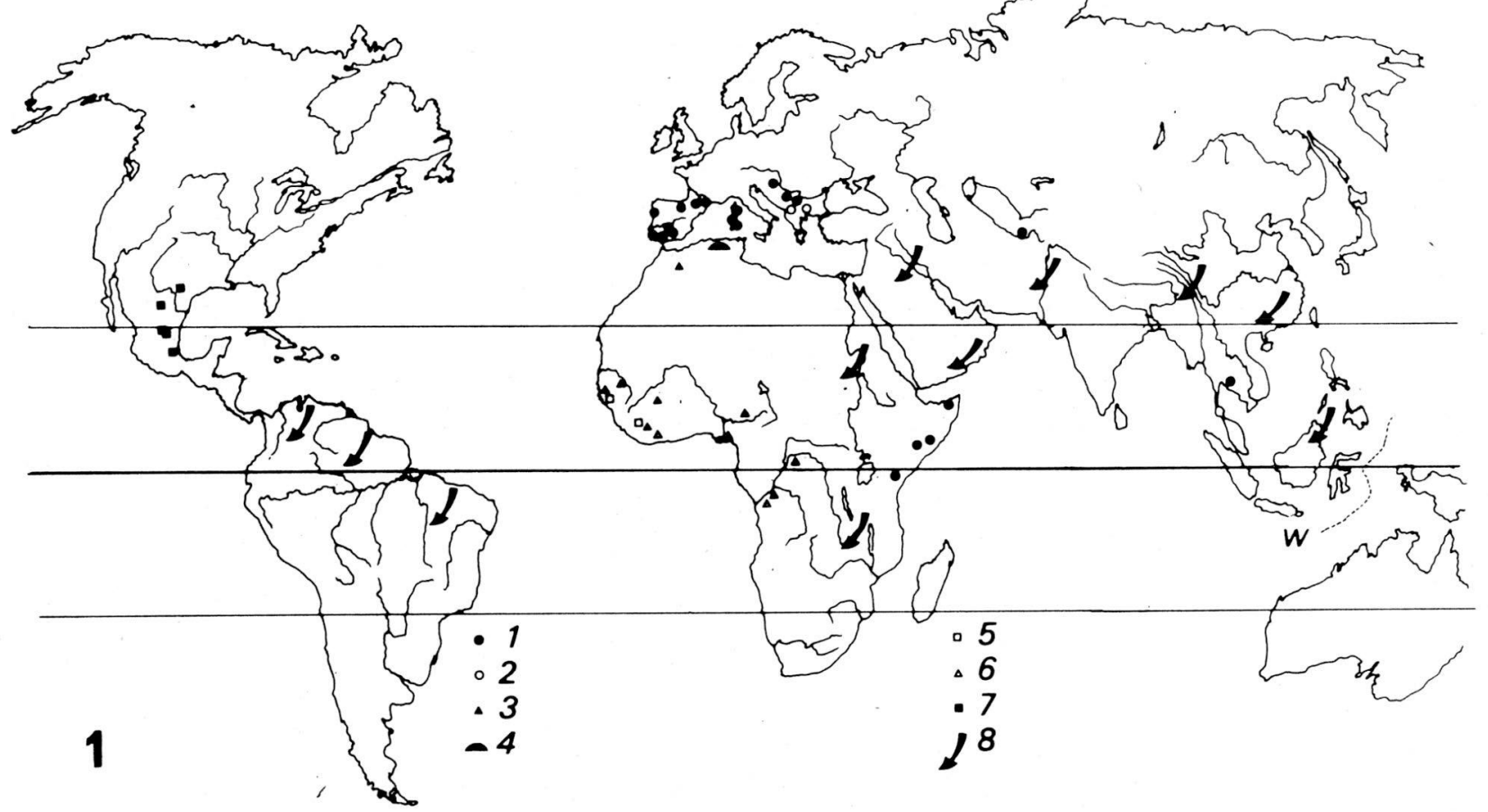

Fig. 1. World repartition of stenasellid isopods. $1=$ Stenasellus stock; $2=$ genus Balkanostenasellus Cvetkov, $1975 ; 3=$ genus Magniezia Lanza, 1966; 4=genus Johannella Monod, 1924; 5 =genus Parastenasellus Magniez, 1966; $6=$ genus MetastenasellusMagniez, 1966; $7=$ American stocks; 8 = arrows pointing out the regions where stenasellids are to be searched for; $W=$ Wallace-Weber line. 
brood pouch. So, we see that the stenasellids are adapted to live in all types of subterranean waters, free water as well as interstitial water. They can also migrate and extend their settlement inside a continuous hydrographic system, and this ecological characteristic is partly responsible for their present dispersal.

\section{SOME PROBLEMS IN THE DISPERSAL OF THE GENUS STENASELLUS}

\section{Stenasellus Virei in Continental France}

In Western Europe, seven endemic Stenasellus species have been found (six in the Iberian Peninsula and one in Mediterranean France). The case of St.virei is quite different: four subspecies of this polytypic species are rather endemic (North Spain, Pyrenees). On the contrary, the last subspecies, St.virei virei, is widely distributed, south as well as north of the Pyrenees (fig. 2). It is the only form that extends widely in the Aquitanian Basin. In this northern part of the area, it is found only in recent interstitial medium: lower terraces of alluvial valleys and underflow of the Garonne and Dordogne rivers and tributaries. The main settlements are always in the lower and middle parts of the valleys, and the underground waters located far from the surface streams are never inhabited by the isopod. We infer that the part of the area of St.v.virei located northwards of the Pyrenees is a zone recently colonized, in Holocene or Postglacial times. Indeed, just after the last glacial sequence (Würm), the rivers have carried and laid down large accumulations of gravels and pebbles which form continuous channels of coarse alluvium, with large interstices, very suitable for the settlement and rapid migrations of the hyporheic fauna (fig. 3). As the periglacial climate had been severe enough, to prevent the stenasellids from living anywhere, but near the Mediterranean or near thermal spring zones, St.virei had been recently an expansive species, being able to extend its settlements over a large area within a period of only some thousands of years. Its expansion is not limited by the present climate, which is propitious, but by the lack of groundwater connections between the GaronneDordogne system and other French hydrographic systems.

\section{Presence of the Virei Stock in Corsica and Sardinia}

A large Stenasellid, St.racovitzai Razzauti, 1925, lives in the karstic and interstitial waters of Corsica and Sardinia. The species is known also in a small karstic area of Tuscany, but this is probably a consequence of a continental connection between Corsica and Tuscany in the early Quaternary, as Tuscany was submerged in Pliocene times. So, St.racovitzai was originally a CorsicaSardinian species. It is strongly related to the species of the Pyrenean zone (virei stock): St.virei, St.buili, St.nobrei, and St.racovitzai have a common origin. Recent geophysical studies point up the fact that the Corsica-Sardinia plate was originally part of a Provence-Catalonia continent, and drifted sou- 


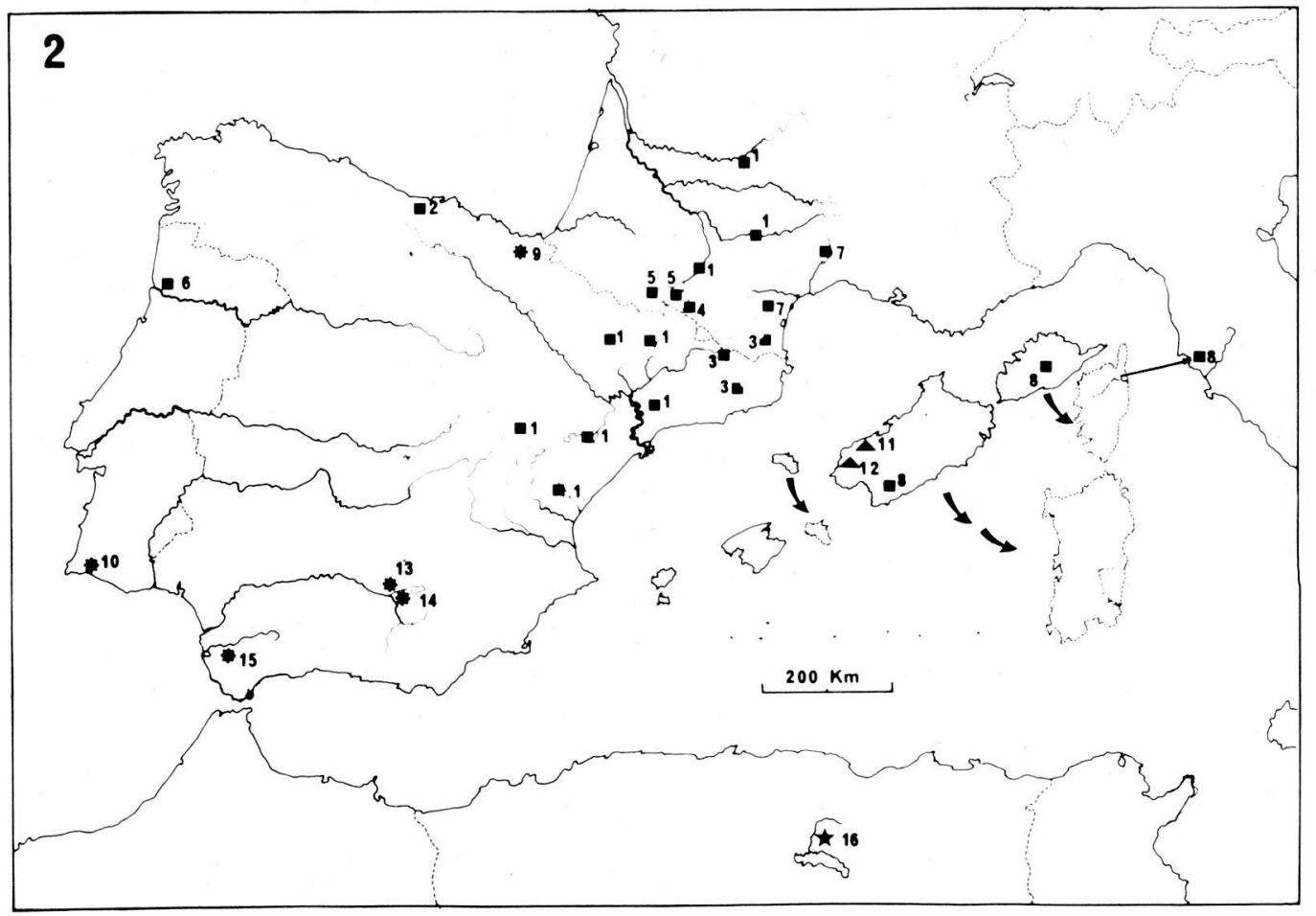

Fig. 2. Repartition of Southwestern Europea!n stenasellids; Corsica, Sardinia and Menorca in Eocene position. Curved arrows point out continental drift, straight arrow points Pleistocene colonization of a point of Tuscany by St.racovitzai. Note the endemicity of all forms, except St.virei virei (1). 1 = Stenasellus virei Dollfus, 1897, subsp. virei or subsp. indet. southeastwards Ebro River; $2=$ St.virei, subsp. buchneri Stammer, 1936; 3 =St.virei, subsp. angelieri Magniez, 1968; 4 =St.virei subsp. boui Magniez, 1968; 5=St.virei, subsp. hussoni, Magniez, 1968; 6 = St.nobrei Braga, 1942; 7 = St.buili Remy, 1949; 8 =St. racovitzai Razzauti, 1925; $9=$ St. breuili Racovitza, 1924; $10=$ St.galhanoae Braga, 1962; $11=$ St.nuragicus Argano, 1968; $12=$ St.assorgiai Argano, 1968; $13=$ St.bragai Magniez, 1976; 14 =St.escolai Magniez, 1976; 15 =St.magniezi Escolà, 1976; 16 = Johannella purpurea Monod, 1924 (African stock). 


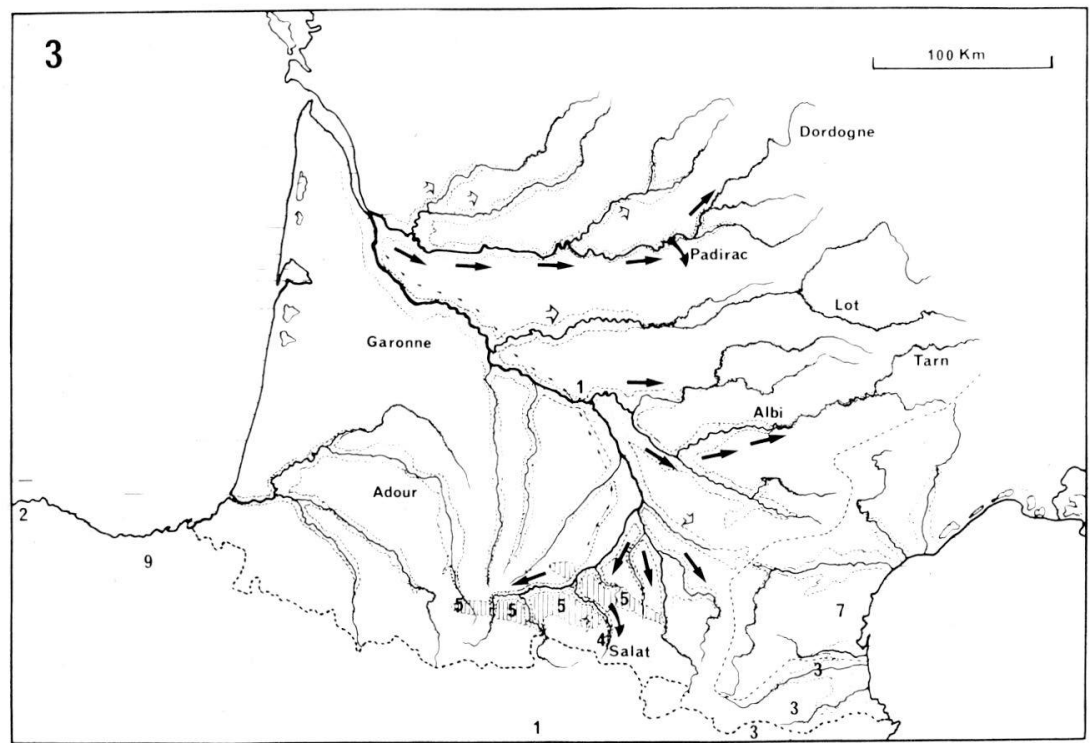

Fig. 3. Colonization of the underground waters of the Aquitanian Basin by Stenasellus virei virei on Holocene times: dotted zones = alluvial valleys with groundwaters; thin arrows $=$ migrations of the fauna under main river; large straight arrows $=$ migrations upwards under the tributaries (black arrows = presence proved by prospections; empty arrows $=$ presence supposed); curved arrows $=$ settling of the karstic system of Padirac; subspeciation and colonization upwards in the underflow of Salat River by St.virei boui; hatched area = north-Pyrenean karstic area of St. virei hussoni; dashed line = limit of area of St.buili; numbers as in fig. 2 .

theastward between the Middle Eocene and the Early Miocene (fig. 2). So, this explains the present dispersal of the virei stock (together in the Pyrenean zone and Corsica-Sardinia, and only there!). Hence, in the Middle Eocene epoch, the stenasellid lines were already a phreatobitic fauna on the Tyrrhenian plate.

\section{General Dispersal of the Genus Stenasellus}

The species of Stenasellus sensu lato (Stenasellus s.s. + Balkanostenasellus Cvetkov, 1975), are known from Southwestern Europe, the Balkan Peninsula, Southeastern and Southwestern Asia and Eastern Africa. Concerning the European stocks, we can state that their areas of distribution always include some continental zones which emerged a long time ago (at least at the beginning of Cretaceous times) - Iberian Meseta for the breuili stock, Tyrrhenian continent for the virei stock, Paleodinarides and Dinarides for the hungaricus and Balkanostenasellus stocks (fig. 4). So, if the Corsica-Sardinia drift indi- 


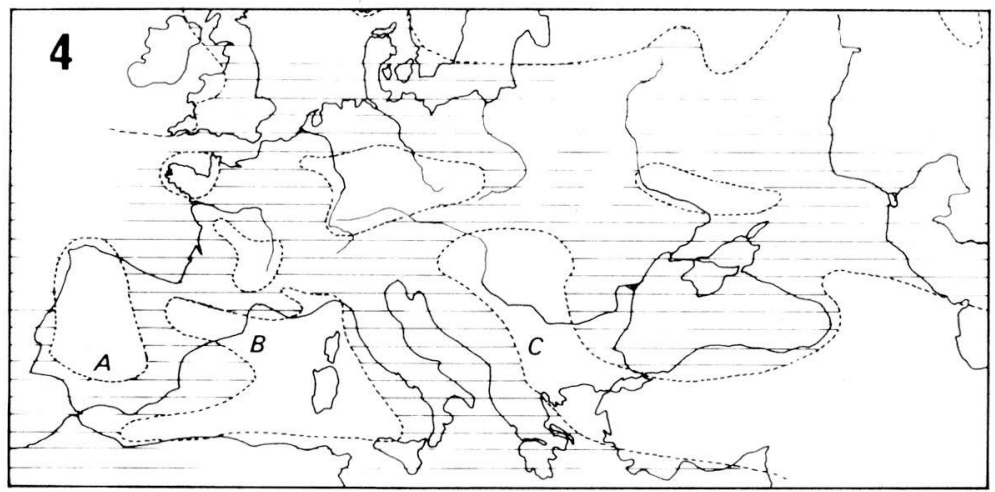

Fig. 4. Paleogeographical map of Europe on Upper Cretaceous, pointing the continental areas of the Mesogean region. Since Lower Cretaceous, these areas are available for colonization by marine ancestors, but we cannot know the date of this colonization. $\mathrm{A}=$ Iberian land (colonized by breuili stock); $\mathrm{B}=$ Tyrrhenian land (colonized by virei stock); $\mathrm{C}=$ Balkan land (colonized by hungaricus and Balkanostenasellus stocks).

cates that continental life was established in the Middle Eocene, then, this life should be more ancient, because the continental medium was available as long ago as early Cretaceous time.

The East-African and South-Asiatic species seem to be morphologically related. However, their three areas (Kenya-Somalia, Turkmenistan, and Cambodia) are so remote from each other that it is untimely to discuss their case. It would be useful to know whether some intermediate populations exist or not, perhaps in the Southern Arabian Peninsula (which was bound to East Africa for a long time), Turkey-Iran region, Central Asia or Southern China. Furthermore, it is not unlikely that the genus Stenasellus was a complex stock, with a common Mesogean ancestor but several independent continental populations.

\section{SOME PROBLEMS IN THE DISPERSAL OF WEST AFRICAN STENASELLIDS}

In Western and Central Africa, three distinct stocks are found - the genus Metastenasellus Magniez, 1966 (six species from the Congolese shield and Gulf of Guinea zone), the genera Parastenasellus Magniez, 1966 (one species) and Magniezia Lanza, 1966 (four species), from the Guinean shield. The species of Magniezia live in underground waters of exorheic basins (Senegal, Gambia, and Sassandra Rivers) as well as in the upper basin of the Niger River, which is an ancient endorheic basin. Recently, I described a new Magniezia (M.gardei, fig. 5) from a Southeastern Moroccan cave (in the upper endorheic basin of the Saoura River). This species is cut off from its congeners 

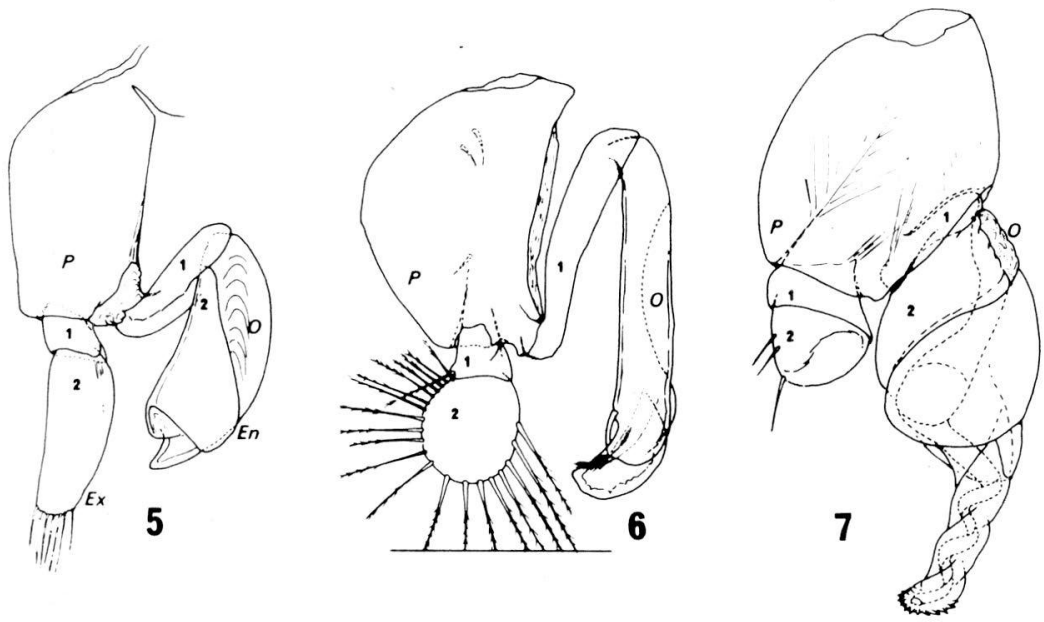

Figs. 5,6,7. $\circ$ 2nd pleopods of the three main African stocks: 5=Magniezia gardei Magniez, 1978, from southern Morocco. Copulatory organ nontwisted. $6=$ Stenasellus kenyensis Magniez, 1974, from Kenya. Copulatory organ slightly twisted. 7=Metastenasellus leleupi (Chappuis, 1951) from Zaire. Copulatory organ strongly twisted. $\mathrm{p}=$ protopodite; En=endopodite; $\mathrm{Ex}=$ exopodite 1 = proximal segment; 2 =distal segment; $\mathrm{O}=$ afferent opening of 2 .En.

by some $2000 \mathrm{~km}$ of arid land (the Western Sahara desert). Since Pliocene ages, the Saharian region has experienced a succession of arid and rainy periods (Faure, 1969; Monod, 1958). During rainy periods, the hydrographic systems became permanent - Oued Saoura coming from the North, Hoggar Rivers from the East, the Upper Niger (not yet captured) from the SouthWest and fed huge freshwater lakes and the phreatic waters developed widely. The present arid period began about 3000 B.P. We can suppose that the Antepleistocene distribution of the genus Magniezia was the entire WestAfrican plate, and the present dispersal is residual. The settlement in eluvial phreatic waters of the West-African craton may be very ancient, as a permanent continental area exists here also and was grazed only by a marine channel (Mediterranean-Gulf of Guinea), on late Cretaceous and Paleocene ages.

\section{THE TRANSATLANTIC DISTRIBUTION OF STENASELLIDS}

Following the discovery of the group in the Western Hemisphere (Cole and Minckley, 1972), some five species have been discovered from Southern Mexico (Argano, 1973) to Southern Texas (Longley, in litt.). In spite of the fact that the males of several species have not been described, the American stocks seem to be well diversified and likely multigeneric. I agree with Cole and Minckley that a certain resemblance exists between Mexistenasellus coa- 
huila from thermal springs of northeast Mexico (fig. 9) and the genus Parastenasellus from the Guinean shield (fig. 8). If it means a relationship with a common continental stock, the continental life of the line must be more ancient than the Cenozoic Era, as the last continental connection between Africa and South America was broken in the Turonian Ages. In this hypothesis, the continental life of African stocks began at least by the early Upper Cretaceous. If some stenasellids are discovered in the future in the phreatic waters of northeast South America (Venezuela-Guiana shield), their study will bring new data for this problem. Furthermore, it will be necessary to explain by what means this groundwater fauna had been able to settle North America, the two American plates having been isolated from each other during the major part of Cenozoic times. Two other hypotheses are possible (fig. 11) - a direct colonization of the North American shield by the same marine stenasellid stocks as in Africa, or that the present American fauna could be a remain of a general preglacial North American settlement; may be in relation with a previous Laurasian settlement (ante Eocene, i.e. prior to the North Atlantic gap).

\section{CONCLUSIONS}

As a consequence of the discovery of numerous north-tropical species, the history of stenasellid isopods appears more complex than former authors thought (Stammer, 1936; Arcangeli, 1938; Chappuis in Racovitza, 1950). The
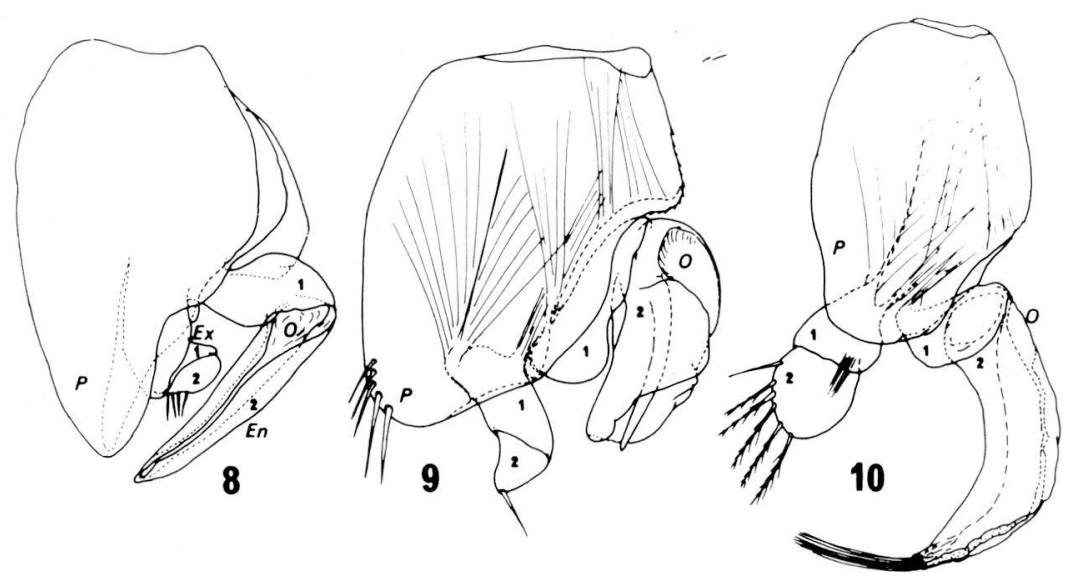

Figs. 8,9,10. or 2nd pleopods of American stocks and African Parastenasellus: $8=$ Parastenasellus chappuisi (Remy, 1938), from Ivory Coast. $9=$ Mexistenasellus coahuila Cole and Minckley, 1972, from northeastern Mexico. 10= Mexistenasellus parzefalli Magniez, 1972, from Central Mexico. A similar organization is visible in P.c., but M.p. is quite different. When the 2 nd $\sigma^{*}$ pleopods of all American species are known, it will appear that the stock is multigeneric. 

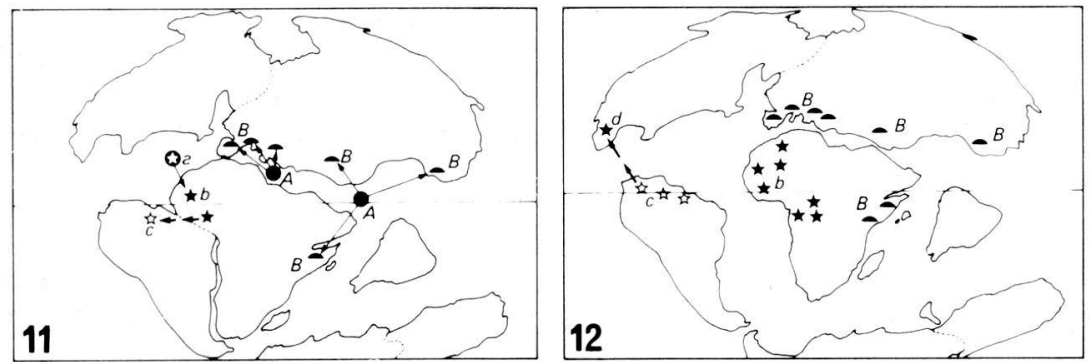

Figs. 11,12. World maps on the beginning (11) and end (12) of Cretaceous times with an hypothesis on the origin of New World stenasellids. a = Mesogean ancestors of the West and Central African stocks; $\mathrm{b}=$ settlement of the Guinean shield and extension; $\mathrm{c}=$ extension to northeast South America; $\mathrm{d}=$ later extension to Southern North America. $\mathrm{A}=$ Mesogean ancestor of the Stenasellus stock; $\mathrm{B}=$ different continental settlements of Stenasellus lines.

marine Mesogean ancestors could have been already interstitial and burrowers in littoral deposits. It is difficult to date their migrations toward continental groundwaters, however, if they are prior to the South American drift, they cannot have occured later than early Upper Cretaceous. This settlement cannot be understood as a passive bringing of marine transgressions, but as an artive conquest upwards by the mean of paleohydrographic systems underflows. Then, a long period of groundwater life could have occurred in the eluvium of paleotropical permanent continental shields. This type of life is always the same for the stocks of wet tropical regions, and their history seems to have been stable. The Mediterranean stocks could have suffered geological aggressions during Cenozoic times - Alpine orogenes, with continental breaking up and drift, marine comings and goings, development of salty basins, etc. ... Then, the Southern European stocks have been affected by Glacial periods, resulting in partial destruction of the stocks(?) endemicity in thermal springs (Lattinger-Penko, 1972), but adaptation to cool conditions for some forms (Magniez, 1974-1975). Finally, in Holocene ages, the latter could have been able to colonize newly suitable hydrographic systems, as in the Aquitanian Basin.

This is a preliminary draft of the history of the group and further investigations and studies are necessary to uncover the details of its different stages.

\section{RÉSUMÉ}

Compte tenu de leur isolement systématique parmi les Asellotes actuels, de leur comportement fouisseur développé, de leur aptitude à la vie interstitielle et de leur vaste répartition mondiale nord-tropicale, l'histoire des Stenasellidae semble marquée par la grande ancienneté de leur installation dans les eaux souterraines continentales (période méso-crétacée?) et par une longue phase de vie dans les eaux phréatiques paiéotropicales des terres émergées en permanence à l'ère tertiaire. La similitude de certaines formes du bouclier guinéen et du Mexique pose le problème 
de l'antériorité de leurs peuplements par rapport à l'ouverture de l'Atlantique Sud. La répartition des formes d'Europe méditerranéenne porte la trace des bouleversements paléogéographiques tertiaires, tandis que leur distribution en Europe continentale a été, de surcroît, troublée par les variations climatiques quaternaires: restrictions des peuplements, endémicité, lors des phases glaciaires, mais large expansion holocène des formes s'étant adaptées aux nouvelles conditions climatiques.

\section{LITERATURE}

ARCANGELI, A. 1938. Stenasellus racovitzai Razzauti, Crostaceo Isopodo acquatico cavernicolo italiano. La famiglia Stenasellidae. Boll. Mus. Zool. Anat. Comp. Torino, 46,1750 .

ARGANO, R. 1973. Mexistenasellus magniezi n.sp., a blind isopod from Veracruz, Mexico (Crustacea). Accad. Naz. Lincei, Roma, 171,97-103.

BÂNARÊSCU, P. 1972. Types of distribution pattern among fresh-water animals. Rev.Roum.Biol., Zool. Bucarest, 17,23-30.

BARR, Th.C., Jr. and J.R. HOLSINGER 1971. Biogeography of Troglobites. Nat. Speleol. Soc. Bull. . U.S.A., 33,115-118.

BOWMAN, Th.E. 1964. Antrolana lira, a new genus and species of troglobitic cirolanid isopod from Madison Cave, Virginia. Int. J. Speleol., 1,229-236, 8 pl.

CHAPPUIS, P.A., et Cl. DELAMARE-DEBOUTTEVILLE 1954. Les Isopodes psammiques de la Méditerranée. Arch. Zool. exper. gén. Fr., 81,103-138.

COLE, G.A. and W.L. MINCKLEY 1972. Stenasellid Isopod Crustaceans in the Western Hemisphere - A new genus and species from Mexico - With a review of other North American freswater Isopod Genera. Proc. Biol. Soc. Washington, 84,313-326, (1971).

CVETKOV, L. 1975. Sur la position systématique des Stenasellinae (Crustacea, Asellota) de Bulgarie. Act. Zool. Bulgar., 1,9-22.

FAURE, H. 1969. Lacs quaternaires du Sahara. Mitt. Internat. Verein. Limnol., Stuttgart, $17,131-146$.

FURON, R. 1957. Le Sahara - Géologie - Ressources minérales - Mise en valeur. Payot, Paris, $300 \mathrm{pp}$.

HOLSINGER, J.R. 1973. Two new species of the subterranean amphipod genus Mexiweckelia (Gammaridae) from Mexico and Texas, with notes on the origin and distribution of the genus. Ass.f.Mexican Caves Studies, Austin, Texas, Bull., 5,1-12.

HOLSINGER, J.R., and G.W. DICKSON 1977. Burrowing as a mean of survival in the troglobitic Amphipod Crustacean Crangonyx antennatus Packard (Crangonyctidae). Hydrobiologia, 54,195-199.

HOLSINGER, J.R., and W.L. MINCKLEY 1971. A new genus and two new species of subterranean Amphipod Crustaceans (Gammaridae) from Northern Mexico. Proc.Biol.Soc. Washington, 37,425-444.

HUGHES, N.F. (ed) 1972. Organisms and continents through time: a symposium. Spec. Pap. Palaeontol., London, 12, VI $+334 \mathrm{pp}$.

HUSSON, R. 1957. A propos de la biologie du Crustacé troglobie aquatique Stenasellus virei Dollfus. Ann.Univ.Sarav.Sc., 6,259-269.

LATTINGER-PENKO, R. 1972. Contribution à la biologie de Stenasellus hungaricus thermalis Mestrov. Crustaceana, Suppl. 3,117-133.

MAGNIEZ, G. 1974-1975. Contribution à la connaissance de la biologie des Stenasellidae (Crustacea Isopoda Asellota des eaux souterraines). Int. J. Speleol., 6,1-80 and 115-171; $7,79-228$.

MAGNIEZ G. 1978. Magniezia gardei n.sp. (Crustacea Isopoda Asellota): un Sténasellide des eaux souterraines du Maroc sud-oriental. Int. J. Speleol., 9,321-329.

MESSANA, G., L. CHELAZZI and B. LANZA 1974. Stenasellus migiurtinicus $\mathrm{sp}$. n., Isopode freatobio della Somalia settentrionale. Monit. Zool. Ital. N.S. Suppl., 5,325-340.

MONOD, Th. 1958. Majâbat al Koubrâ. Contribution à l'étude de l' "Empty Quater" ouestsaharien. Mém. Inst. fr. Afr. noire, Dakar, 52,407 pp.

POULSON, Th. L. and W.B. WHITE 1969. The cave environment. Science, 165, 971-981. 
RACOVITZA, E.G. 1950. Asellides, première série: Stenasellus. Arch. Zool. expér.gén.Fr., 87, $1-94$.

STAMMER, H.J. 1936. Eine neue Höhlenwasserassel aus Spanien, Stenasellus Buchneri und die Verbreitung der Gattung Stenasellus. Zool. Anz. Dtsch., 114-137-141.

TERMIER, H. and TERMIER G. 1974. Tectonique globale et paléogéographie. in Encyclopaedia Universalis, 17,574-579.

VANDEL, A. 1971. Evolution biologique et dérive des continents: une expérience naturelle portant sur cent cinquante millions d'années. C.R.Acad.Sc.Fr., 272,253-256.

VIRÉ, A. 1902. La faune et la flore souterraines de Puits de Padirac (Lot). Bull. Mus. Hist. nat. Paris, 8,601-607. 



\title{
Perspectives in the Study of the Zoogeography of Interstitial Crustacea: Bathynellacea (Syncarida) and Parastenocarididae (Copepoda)
}

\author{
Horst Kurt Schminke*
}

SUMMARY

Aspects of the zoogeography of Bathynellacea and Parastenocarididae are discussed in the light of my recent investigations. Parastenocarididae in Australia are rare and not very diverse in number of species. Four species belonging to three genera were collected on a tour through $\mathrm{Au}-$ stralia in 1968. Despite relationships to species from other Gondwanian landmasses the poorness of the Australian fauna, together with the apparent ability of this family to spread over longer distances, suggest a late arrival of Parastenocarididae in Australia. Invasion is likely to have taken place from two directions. As for the Bathynellacea, the relationships presumed to exist between genera from Australia and Malaysia within the Parabathynellidae have been invalidated. As an alternative to the double-armed dispersal model of the Parabathynellidae propounded earlier, a vicariance model is discussed following Schram (1977). The zoogeography of Parastenocarididae can probably be best explained in terms of a primary dispersal history.

Two groups among crustaceans belong to the most characteristic elements of freshwater interstitial fauna: the Bathynellacea, an order of the Syncarida within the Malacostraca, and the Parastenocarididae, a family of the Copepoda Harpacticoidea. I have been interested in the Bathynellacea for a long time and have recently been studying the Parastenocarididae. Particular emphasis in this work has been placed on problems of historical zoogeography. Why select just these two groups for this kind of study?

\section{PARASTENOCARIDIDAE}

The Australian fauna is a good case in point to explain this. On a collecting tour through Australia in 1968, I took 45 samples of freshwater interstitial fauna in New South Wales, Victoria, Western Australia and on Tasmania (Schminke 1973, fig. 3). The sorted samples showed a surprising result. Only 13 of $45(29 \%)$ yielded Parastenocarididae species, whereas Bathynellacea were present in $20(45 \%)$ of them. The usual situation is just the opposite. In South Africa for example, 65 of 89 samples $(73 \%)$ contained species of Parastenocarididae whereas Bathynellacea were extracted from only $44(50 \%)$ of

\footnotetext{
* Fachbereich IV, Universität Oldenburg, Ammerländer Heerstr., D-2900 Oldenburg, Germany.
} 
these. In New Caledonia 34 of $52(65 \%)$ samples yielded species of Parastenocarididae whereas Bathynellacea were absent.

Equally surprising, though in agreement with the low number of samples yielding Parastenocarididae at all, was the fact that, except for one, all of the samples contained only one species. This is very poor. In New Caledonia the average was two species per sample with some samples containing four or five species. In South Africa the average was three species, with a few samples yielding as many as six or seven species. Parastenocarididae are not only rare in Australia, they are also not very diverse in the number of species. Despite the huge area sampled only four species were found.Three of them were encountered in Eastern, and a single species in Western Australia. None were found on Tasmania.

The systematics of the Parastenocarididae are still in a state that precludes far reaching conclusions as to the phylogenetic relationships of its genera. But my own extensive work during the last two years, yet to be published, has at least unveiled criteria for a clear delimitation of these genera. According to these criteria, the four Australian species can be assigned to three genera. The species from Western Australia belongs to the genus Cafferocaris, which has a great number of species and is widely distributed all along East Africa, from Kenya down to South Africa and also on Madagascar. Two of the species from Eastern Australia representing a new genús are very closely related to, if not congeneric with, species from India (material, leg. Noodt) and Sri Lanka (Enckell, 1970). The remaining species and genus cannot be classified as yet.

From these relationships it may appear that the Australian species are remnants of an old Gondwanian stock, the descendants of which are now scattered over the once interconnected continents in the southern hemisphere. But if Parastenocarididae have been in Australia for such a long time, why are they so rare? In Africa and South America, this family is virtually teeming with species. The alternative would be that Parastenocarididae are of fairly recent occurrence in Australia. Their dispersive capacity appears to be such as to allow dispersal over longer distances (Enckell, 1969; Kulhavy and Noodt, 1968). By what means this is achieved we do not know. Yet, not only have Parastenocarididae been recorded from purely volcanic islands such as Iceland (Kulhavy and Noodt, 1968), and Tenerife of the Canary Islands (Schminke, 1971), which they could not have reached by land connections, they also are not entirely interstitial in existence.Some species have been found in mosses and on the Indonesian islands in phytothelms (Chappuis, 1931).

An invasion into Australia long after the breakup of Gondwana, therefore, does not appear to be completely out of the question. The distribution of the Australian genera and their affinities to species from other continents would, on the contrary, be better explained by this hypothesis, as would what appears to be a thinning out of Parastenocarididae to the south within Australia and their probable absence from Tasmania. But confirmation is needed from additional sampling before their absence from Tasmania can be taken for granted. A late arrival in Australia of this family would also make 
less surprising their probable absence from New Zealand. About 190 samples of freshwater interstitial fauna were taken throughout New Zealand in 1967/68 (Schminke 1973, fig. 2), but no Parastenoearididae were discovered.

Current evidence, then, seems to suggest an arrival of Parastenocarididae in Australia after the rupture of the Gondwanian landmass. It is impossible to give even a rough estimate for the probable date of this arrival. One reason is that the invasion seems to have taken place from the north as well as from the west. In addition, these considerations still suffer from two major deficiencies: lack of sufficient knowledge of the phylogenetic relationships within the Parastenocarididae, and existence of large gaps in the recording of the occurrence of this family in many parts of the world.

\section{BATHYNELLACEA}

The Bathynellacea seem to provide better opportunity for formulating hypotheses. At least within the family Parabathynellidae, the phylogenetic relationships of its genera are better known. From these I concluded (Schminke, 1973, 1974) that the Australian genera are part of one of two independent lines along which the Parabathynellidae were believed to have dispersed from their center of origin in east Asia, where the most primitive species occur. Along both lines, the genera become more and more apomorphic in their characters. One line was assumed to have led west via Europe and Africa to South America, the other south via Australia to South America.

Because of the very poor dispersive capacity of the Bathynellacea (Schminke, 1974), dispersal from Asia to Australia could not have taken place unless land connections had existed between Asia an Australia at a time that would not only have enabled the Parabathynellidae to subsequently reach New Zealand but also to extend their range to South America via Antarctica. A constellation of the landmasses in the southern hemisphere which would have allowed this sequence of events does not seem to have existed, if the latest reconstructions of the earth's history are correct. This need not concern us too much since not in seeking mere coincidences between distributional patterns and geological constellations, viz. by simultaneously taking into account biological as well as geological evidence, can zoogeographical studies provide significant contributions to the reconstruction of the earth's history. Zoogeographical studies can contribute to it only in tracing causal relationships by independently applying their own genuine methodology (Müller, 1974). This may result, as in the present case, in contradictions with evidence from other sources. When this happens, it does not mean that the reconstructions of phylogenetic relationships underlying the zoogeographical conclusions must by necessity be false. However, as a potential source of falsification, such contradictions invite reconsideration of the phylogenetic analysis.

The weak points, then, in reconstructing the phylogenetic relationships within the family Parabathynellidae obviously are those presumed to exist between the Malaysian genus Batubathynella and some of the Australian ge- 
nera because of great similarities in the complicated structure of the male thoracopods VIII. Reexamination of abundant new material of the genus $B a$ tubathynella (leg. Fernando), which was in far better condition than the specimen available for the earlier study, showed that the picture gained from that specimen could not be substantiated. Independent evidence suggesting that these presumed relationships were probably due to misinterpretations came from a study of South African Bathynellacea (Schminke, unpubl.). If the hypothesis of a double armed dispersion of the Parabathynellidae from a center of origin in east Asia were correct, there should have been no overlap in South Africa of representatives of the genera characteristic for the two independent routes of dispersal leading up to South America. Such an overlap, however, does in fact occur. What, then, could an alternative look like?

\section{PERSPECTIVES}

Debate in historical zoogeography lately has centered around what has been called the dispersal and vicariance paradigms (Platnick and Nelson, 1978). The vicariance model requires an ancestral species which enlarges its initially small area of distribution. This initial primary dispersal, which in the extreme may lead to cosmopolitanism, takes place in the absence of a barrier. Subsequent geological or other events may result in fragmentation of this area into two isolated ones by the appearance of a barrier, and in differentiation of the then isolated populations into two allopatric species. Subsequent fragmentations of the areas of these species, followed by further speciation events, could lead, without any further dispersal, to a worldwide pattern of distribution which in most groups is usually complicated by events of secondary dispersal indicated in the recent fauna by sympatry.

The dispersal model, on the other hand, differs from the vicariance model in the relative age of disjunctions and barriers. According to this model, an ancestral species extends its range by dispersal across a preexisting barrier, resulting in immediate isolation and disjunction of its offshoot. Disjunction and barrier are of different ages, the latter being older, whereas, according to the vicariance model, both are the same age. For a more detailed treatment of this theoretical background, the reader should see discussions in Ball (1975, 1977), Croizat et al. (1974), and Platnick and Nelson (1978).

Schram (1977) recently suggested that the worldwide pattern of distribution of the Bathynellacea may probably be better understood in terms of vicariance rather than a classic dispersal model such as the one I have propounded. As pointed out by Platnick and Nelson (1978), many alleged dispersal hypotheses are in reality what they call vicariance models in disguise. These are not really dispersal models because the postulated dispersal is supposed to have taken place "prior to the appearance of the barrier and prior to the fragmentation of the range of the ancestral species" (p. 2). My "dispersal" model of bathynellacean distribution falls under this heading. If we look at the distribution ranges of the parabathynellid genera with this in mind (fig. 1), Schram's view becomes easily understandable. All intrageneric con- 


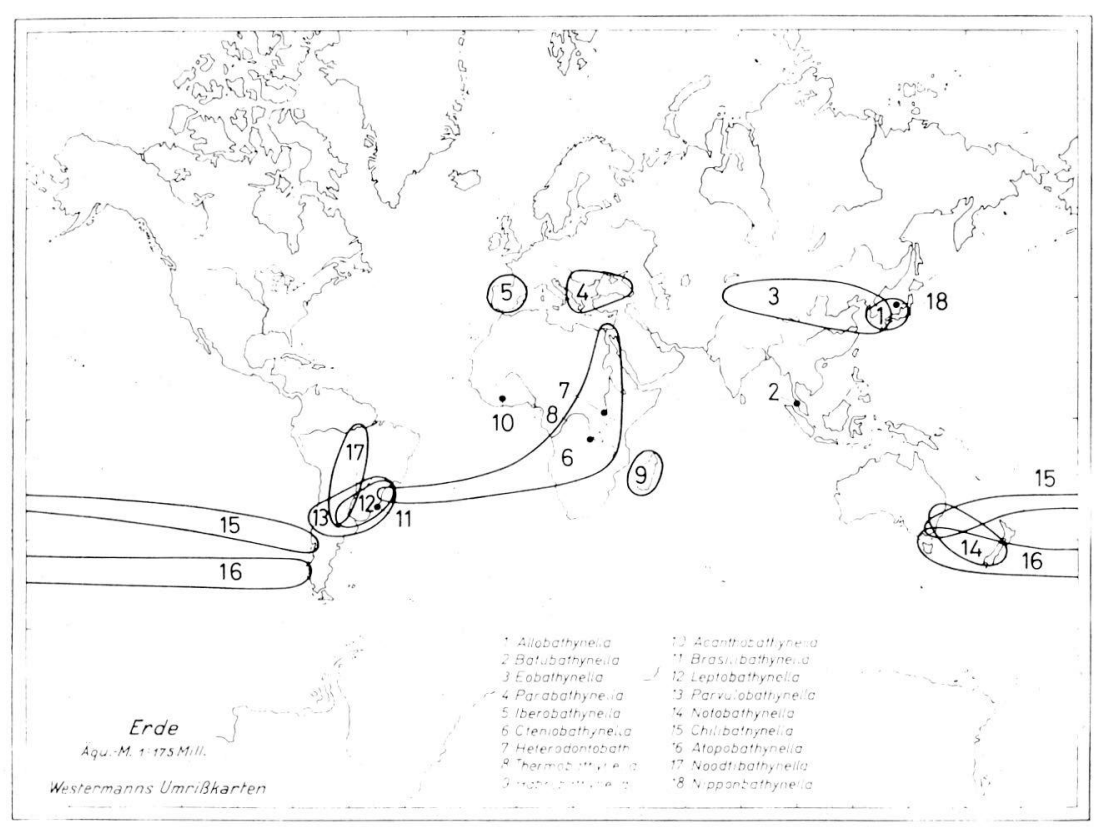

Fig. 1. Distribution of the genera of the family Parabathynellidae (without genus Hexabathynella). (After Schminke, 1973.)

nections run east-west, and even the intergeneric ones never run north-south except for the case that has turned out to be untenable. This picture will become even more pronounced when my records of the genera Chilibathynella and Leptobathynella from Africa, Atopobathynella from Madagascar, and Iberobathynella from North America appear in print.

Bathynellacea, then, appears to belong to those groups of organisms which reached a cosmopolitan distribution prior to the breakup of Pangaea, and whose zoogeography can now be understood only in terms of vicariance and secondary dispersal. If this is true, phylogenetic studies should result in the distinction of two monophyletic groups within the Parabathynellidae, a northern or laurasian group and a southern or gondwanian one.

It is not yet clear which explanation best fits the distribution of Parastenocarididae. The depauperate Australian fauna and the apparent ability of this family to spread over longer distances suggest that their zoogeography may probably be best explained in terms of a primary dispersal history. Their phylogenetic age also appears to point in this direction. An origin in the early Tertiary, or even somewhat earlier, has tentatively been suggested for this family (Noodt, 1969).

The Bathynellacea, in comparison, are decidedly older, circumstantial evidence pointing to an origin as far back as the Carboniferous. They are old 
enough to have been subject to all consequences of the breakup of Pangaea, the sequence of their phylogenetic branchings probably being a mirror, to some extent, of the sequence of geological changes. The Parastenocarididae, on the other hand, are not likely to have witnessed directly, to their full, the repercussions of continental disruption. They had to achieve post festum what the Bathynellacea had reached before: a worldwide distribution. Thus, the history of both groups is apt to cast some light on how the continents evolved. Each, however, does it from a different direction, and it is this double aspect that makes it worthwhile to pick just these two groups among interstitial Crustacea for studies with emphasis on problems of historical zoogeography.

\section{ACKNOWLEDGEMENTS}

Grants which enabled me to collect the material referred to in this study were provided by the following organizations: Deutscher Akademischer Austauschdienst, Fritz-Thyssen-Stiftung, Deutsche Forschungsgemeinschaft. I thank Prof. Dr. C.H. Fernando, University of Waterloo, Canada, for the gift of several specimens of Batubathynella malaya. Dr. T. Gledhill, Wareham, England, was so kind to help with my English.

\section{ZUSAMMENFASSUNG}

Es werden Aspekte erörtert, die sich im Verlauf meiner neuesten Untersuchungen zur Zoogeographie der Bathynellacea und Parastenocarididae ergeben haben. Die Parastenocarididae Australiens fallen durch seltenes Vorkommen und geringe Artenzahl auf. Die Ausbeute einer ausgedehnten Sammelreise durch Australien im Jahr 1968 bestand aus nur 4 Arten, die 3 Gattungen angehören. Trotz verwandtschaftlicher Beziehungen zu Arten von anderen gondwanischen Kontinenten legen die Artenarmut der Familie in Australien und ihre vermutliche Fähigkeit zu weiträumiger Ausbreitung eine späte Ankunft in Australien nahe. Di Besiedlung dieses Kontinents fand höchstwahrscheinlich aus 2 verschiedenen Richtungen statt. Hinsichtlich der Bathynellacea haben sich vermutete Verwandtschaftsbeziehungen zwischen Gattungen der Familie Parabathynellidae aus Malaysia und Australien nicht bestätigt. Alternativ zu dem früher vertretenen, zweiarmigen Verbreitungsmodell der Parabathynellidae wird im Anschluß an Schram (1977) die Möglichkeit eines Vikarianzmodells erörtert. Die Zoogeographie der Parastenocarididae ist wahrscheinlich am besten durch ein Modell primärer Ausbreitung zu erklären.

\section{LITERATURE}

BALL, I. 1975. Nature and formulation of biogeographical hypotheses. Syst. Zool. 24: 407-430. BALL, I. 1977. On the phylogenetic classification of aquatic planarians. Acta Zool. Fenri. 154: 21-35.

CHAPPUIS, P.A. 1931. Copepoda Harpacticoida der Deutschen Limnologischen SundaExpedition. Arch. Hydrobiol., Suppl. 8: 512-584.

CROIZAT, L., NELSON, G. and D.E. ROSEN 1974. Centers of origin and related concepts. Syst. Zool. 23: 265-287.

ENCKELL, P.H. 1969. Distribution and dispersal of Parastenocarididae (Copepoda) in northern Europe. Oikos 20: 493-507.

ENCKELL, P.H. 1970. Parastenocarididae (Copepoda Harpacticoida) from Ceylon. Ark. Zool., Ser. 2, 22 (13): 545-556.

KULHAVY, V. and W. NOODT. 1968. Über Copepoden (Crustacea) aus dem limnischen Mesopsammal Islands. Gewäss. Abwäss. 46: 50-61.

MÜLlER, P. 1974. Aspects of zoogeography. Dr. W. Junk bv Publishers, The Hague.

NOODT, W. 1969. Die Grundwasserfauna Südamerikas, in: Biogeography and ecology in South 
America, FitTkAU E.J., ILliES J., KLINGE H., SCHWABE G.H., and SiOLI H., Eds., Dr. W. Junk N.V., The Hague, Tome 2: 659-684.

PLATNICK, N.I., and G. NELSON, 1978. A method of analysis for historical biogeography. Syst. Zool. 27:1-16.

SCHMINKE, H.K. 1971. Zwei neue Parastenocaris-Arten (Copepoda, Harpacticoidea) von Tenerife (Kanarische Inseln). Gewäss. Abwäss. 50/51: 66-75.

SCHMINKE, H.K. 1973. Evolution, System und Verbreitungsgeschichte der Familie Parabathynellidae (Bathynellacea, Malacostraca). Akad. Wiss. Lit. Mainz, Math.-nat. Kl., Mikrofauna Meeresboden 24:1-192.

SCHMINKE, H.K. 1974. Mesozoic intercontinental relationships as evidenced by bathynellid Crustacea (Syncarida: Malacostraca). Syst. Zool. 23:157-164.

SCHRAM, F.R. 1977. Paleozoogeography of the late Paleozoic and Triassic Malacostraca. Syst. Zool. 26:367-379. 



\title{
Distribution of Ostracods in the Groundwater of the North Western Coast of Euboea (Greece)
}

\author{
Dan L. Danielopol*
}

\begin{abstract}
SUMMARY
Freshwater fauna from 20 wells located $15-200 \mathrm{~m}$ from the seashore as well as marine interstitial fauna from the coastal zone around the village Aghios Georghios (Cape Likhada) have been investigated. Freshwater hypogean ostracods live mainly in protected wells having clean bottom and little particulate organic matter from which the water is moderately pumped. Epigean freshwater ostracods dominate in unprotected wells with large amounts of organic matter on the bottom. There is a sharp difference between the ostracod fauna living in fresh groundwater (mainly Cypridids) and those living in coastal marine interstitial habitats (marine Cytherids and Polycopids).

It is suggested that in the Mediterranean realm the hypogean fauna could be found easily in protected wells with little organic matter accumulation, where water is moderately pumped.
\end{abstract}

\section{INTRODUCTION}

The scarce information on freshwater interstitial fauna of Greece has recently been reviewed by Bou (1975) and Matsakis (1975). Bou visited Greece during 1969 and 1971 and extensively sampled hypogean fauna (see his report, 1975). Prior to 1969 , Schäfer (1945) and Stephanides (1948) sampled fauna from wells, the former collected in Thessaly around Carla Lake at about 25$40 \mathrm{~km}$ in from the sea coast; the latter investigated several wells in Corfu Island. Schäfer found a rich hypogean ostracod fauna and also reported (1951) that some of the well fauna from Thessaly came from a limestone area. Therefore it was not clear if Schäffer's ostracods live in a porous aquifer or in a karstic one. Considering the typical interstitial fauna accompaning the ostracods from Thessaly (Microcharon (Isopoda), Parastenocaris, Sigmatidium (Harpacticoida) as well as the minute size of ostracods belonging to the genera Kliella, Nannokliella and Mixtacandona (see Schäfer, 1945), I hypothesized (1971 and 1977) that the ostracods should be interstitial inhabitants. Stephanides (1948), quite opposed to Schäfer, found only epigean fauna in the wells of Corfu.

Bou offered me the ostracods he collected in many wells in Greece, and I found that, in addition to the well samples containing blind hypogean ostracods, there were also some samples in which epigean fauna dominated. In or-

* Limnologisches Institut, Berggasse 18, A-1090 Wien. 


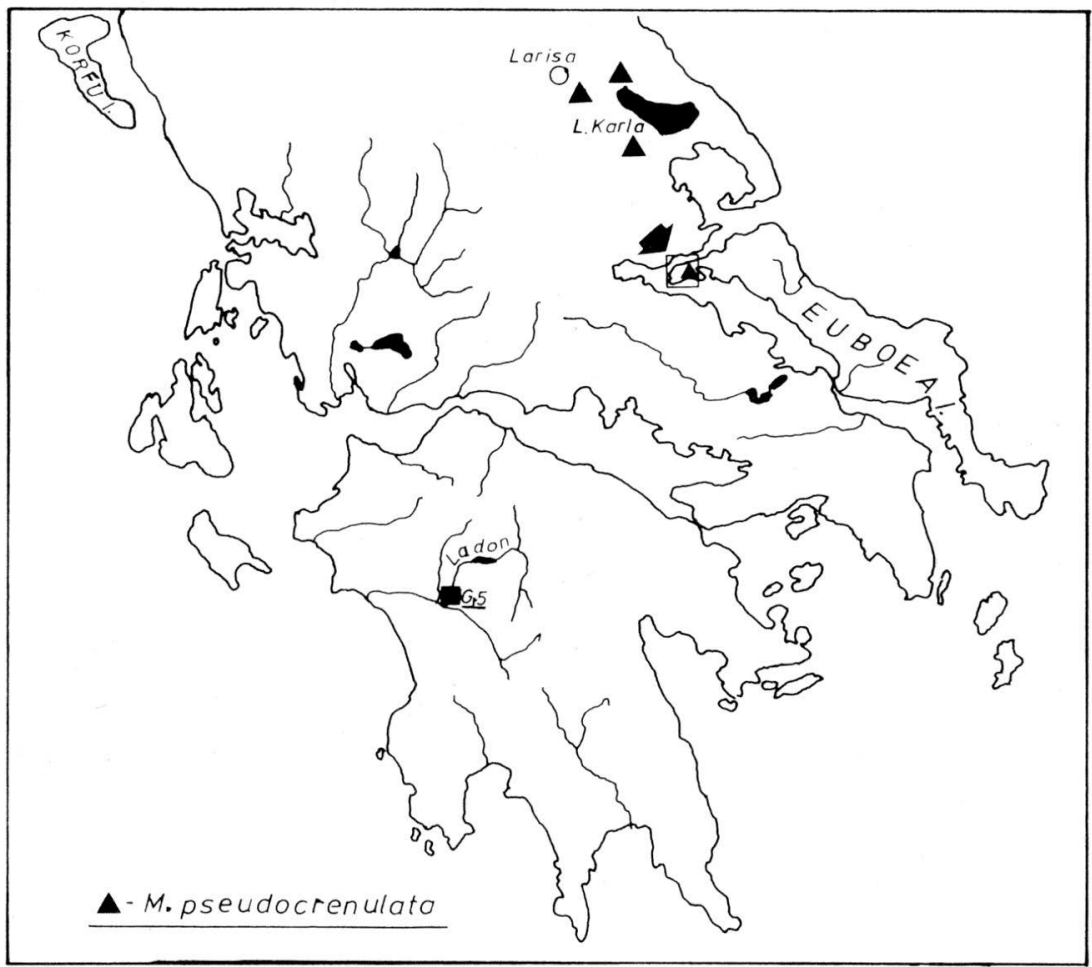

Fig. 1. General view of Greece. The arrow indicates the northwestern coast of Euboea where the interstitial fauna was investigated in 1976. The triangle indicates the distribution of Mixtacandona pseudocrenulata Schäfer. The square indicates the station Greece 5 on the Ladon Valley (see Bou, 1975).

der to explain these faunistic differences, I hypothesized that the wells where epigean fauna dominated are polluted and hence unfavorable for hypogeans.

During the latter part of August and early September, 1976, I visited Greece in order to verify this hypothesis and tried to verify some of the ostracod species found by Schäfer. A report on a new freshwater ostracod of marine origin found in Greece has been presented elsewhere (Danielopol, 1979).

The strategy of my sampling program was different from that of Bou, who extensively collected fauna over a large territory (see figure 1 in his 1975 report). I decided to investigate a restricted area along the northwestern coast of Euboea Island (fig. 1 and 2) around the village Aghios Georghios Likhadas and the Biological Station Keramou. From the data of Bou $(1974,1975)$, Coineau (1969), and Matsakis (1975), I knew that the wells in this area have a diverse fauna. 


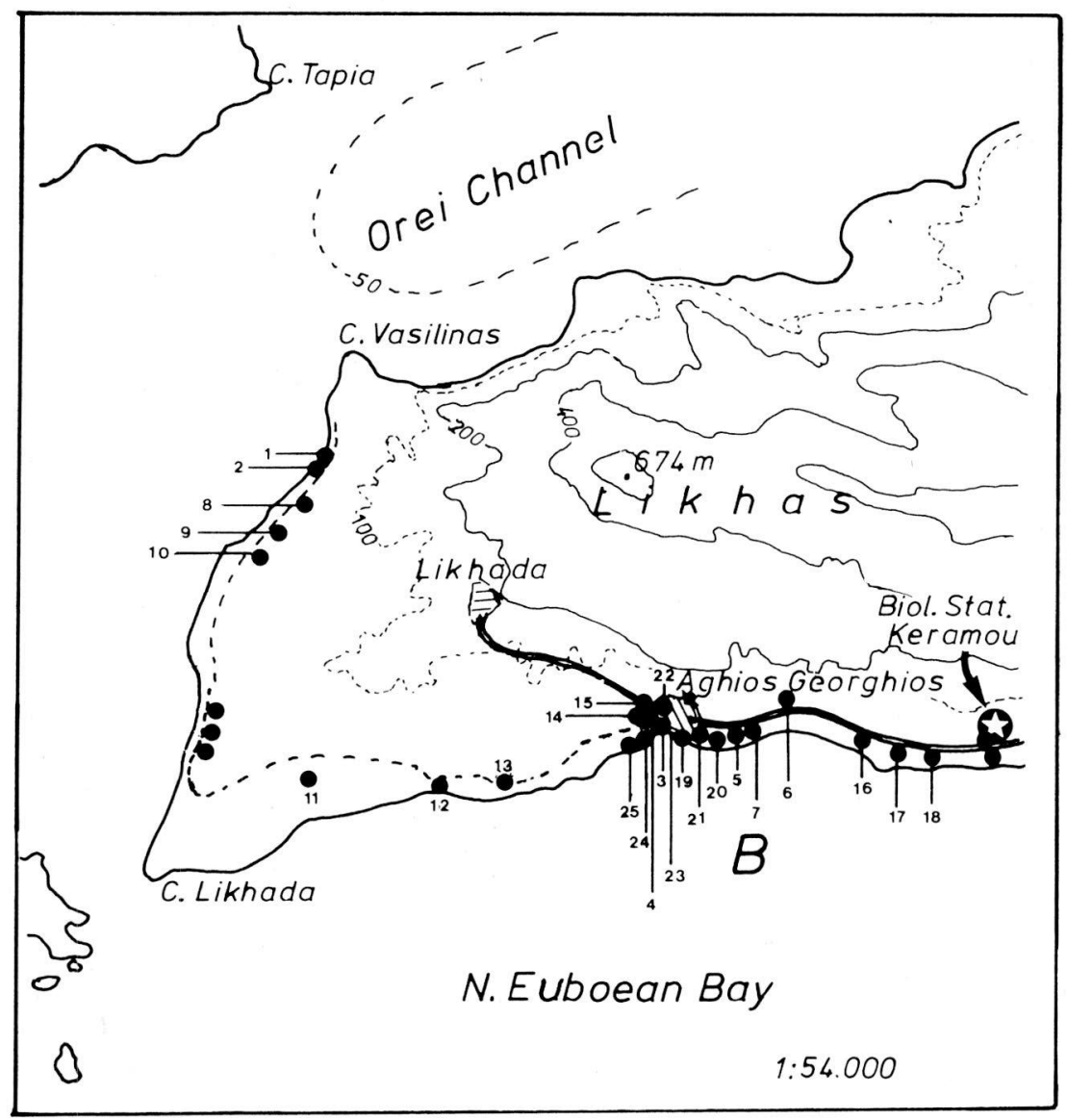

Fig. 2. The northwestern part of Euboea near the village Aghios Georghios and the Biological Station Keramou. 1-24 are the sample sites mentioned in table 1. The isobath - 50m in the Orei channel - drawn after Yannopoulos and Barrois (1975).

THE SAMPLING AREA (fig. 1, 2, 3, table 1)

The northwestern part of Euboea is dominated by the limestone rocks of the mountain Likhas (674 m altitude). On the western side of the Island (Zone B, fig. 2), the lowland is extremely reduced (about $300 \mathrm{~m}$ width). On the northern part between Cape Likhada and Cape Vasilinas (Zone A, fig. 2), the plain becomes wider. A porous aquifer exists in the coastal lowland which supplies the water needed by the inhabitants. I had the opportunity to examine the sediment extracted from a borehole during the construction of well number 18. It was mainly sand with marine fossils (spicules of sponge). In 


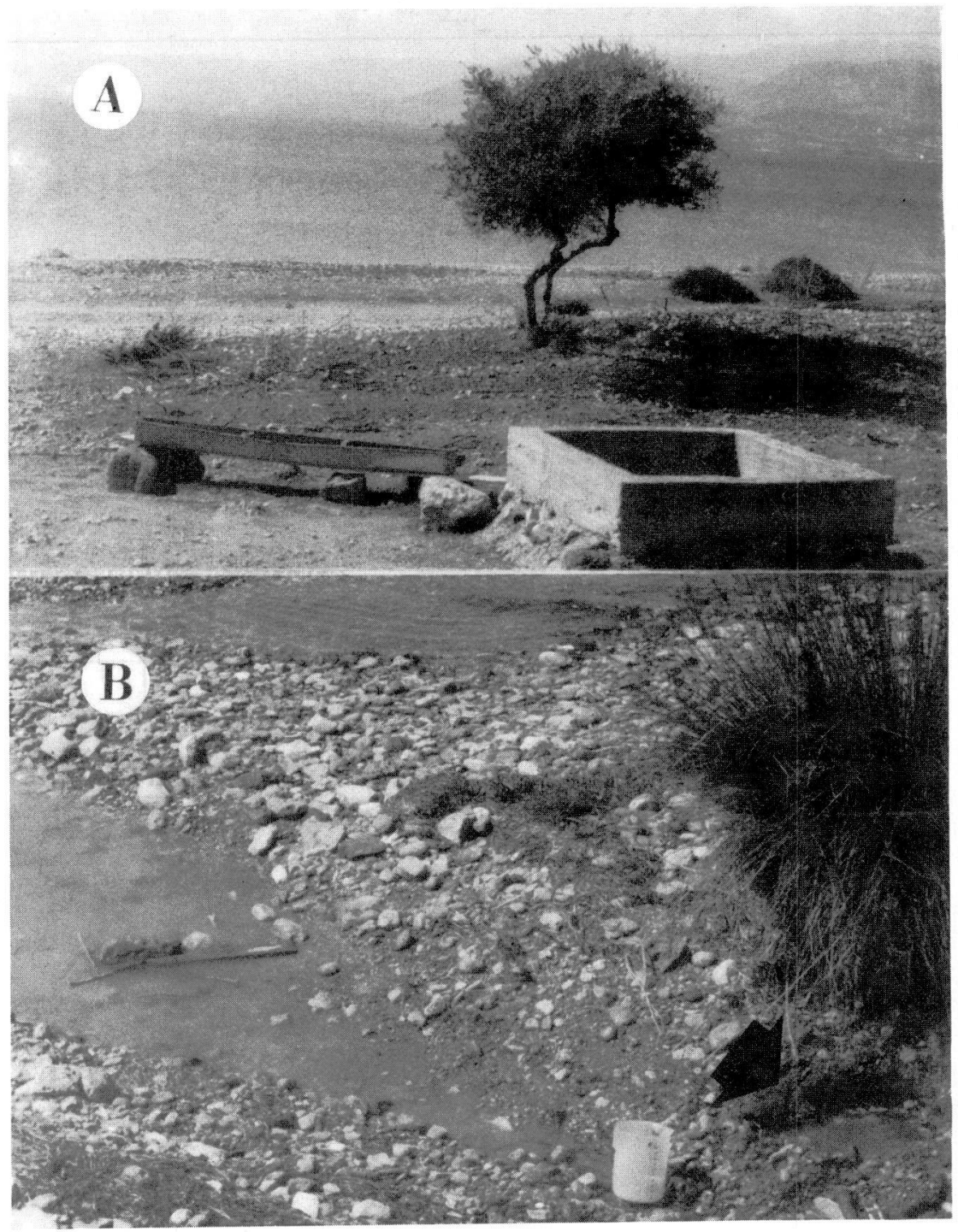

Fig. 3A. Site number 1 sampled using the Karamann-Chappuis' method. $B$. Well number 9, general view (see for location fig. 2). 
Table 1. The main characteristics of the sampling sites.

\begin{tabular}{|c|c|c|c|c|c|c|c|c|c|c|c|c|c|}
\hline $\begin{array}{c}\text { EUBOEA } \\
\text { sample } \\
\text { number }\end{array}$ & $\begin{array}{l}\text { (E) } \\
\text { I }\end{array}$ & II & III & IV & V & VI & VII & VIII & IX & $x$ & XI & XII & Fauna \\
\hline 1 & SL & 0.5 & $\mathrm{~K}-\mathrm{Ch}$ & $0.1 \cdot 0.2$ & $0.1-0.2$ & sa,pe,si & ++ & 29.46 & $27^{\circ}$ & - & - & - & $\mathrm{Hy}, \mathrm{E}$ \\
\hline 2 & SL & 0.5 & $\mathrm{~K} \cdot \mathrm{Ch}$ & 0.1 & $0.1-0.2$ & sa,pe & + & 25.91 & $29^{\circ}$ & - & - & - & E \\
\hline . 3 & W & 19 & $C, C N, P N$ & 2.0 & 0.6 & a,pe & + & 0.09 & $19.5^{\circ}$ & UNU & $\mathrm{Co}^{* *}$ & - & $\mathrm{Hy}, \mathrm{E}$ \\
\hline 4 & W & $60-70$ & $\mathrm{PN}$ & 5 & - & sa & + & 0.14 & $19.5^{\circ}$ & Ga ir & Co ce & $\begin{array}{c}\mathrm{hPu} \\
\mathrm{m}+\mathrm{Pu}\end{array}$ & $\mathrm{Hy}$ \\
\hline 5 & W & $40-50$ & $\mathrm{CN}$ & 5.0 & 1 & at & + & 0.13 & $?$ & Dr Wa & Co $\mathrm{w}$ & bu + & $\mathrm{Hy}, \mathrm{E}$ \\
\hline 6 & W & $80-100$ & $\mathrm{CN}$ & 7.8 & 0.5 & a & + & - & $18^{\circ}$ & Dr Wa & Co ce & $\mathrm{m} \mathrm{Pu}$ & $\mathrm{Hy}$ \\
\hline 7 & W & $40-50$ & $\mathrm{CN}$ & $6-7$ & 1 & ? & + & - & ? & UNU & UCo & - & $\mathrm{E}, \mathrm{Hy}$ \\
\hline 8 & W & 30 & . $\mathrm{CN}$ & 2.5 & 0.5 & ? & ++ & 0.07 & ? & Wa S & UCo & ? & $\mathrm{E}$ \\
\hline 9 & W & 300 & $\mathrm{CN}$ & 2.5 & 0.5 & $?$ & ++ & 0.08 & $?$ & Wa S & UCo & ? & $\mathrm{E}$ \\
\hline 10 & W & 20 & $\mathrm{CN}$ & 1.8 & 0.5 & a & ++ & 0.17 & ? & Wa S & UCo & ? & $\mathrm{E}$ \\
\hline 11 & W & 100 & $\mathrm{CN}$ & 2.0 & 0.8 & $\mathrm{mu}$ & +++ & 0.41 & $21^{\circ}$ & Ga ir & UCo & ? & $\mathrm{E}$ \\
\hline 12 & W & 20 & $\mathrm{CN}$ & 1.2 & 1 & ৎа & + & 0.08 & $22^{\circ}$ & Wa S & $\mathrm{UCo}$ & ? & $\mathrm{E}$ \\
\hline 13 & W & 50 & PN & $?$ & $?$ & $?$ & - & 1.27 & $19^{\circ}$ & Wa S & Co ce & $\begin{array}{l}\mathrm{hPu} \\
\mathrm{mPu}\end{array}$ & $\mathrm{Hy}$ \\
\hline 14 & W & 60 & $\mathrm{CN}$ & 2.5 & 0.5 & $?$ & + & 0.57 & $\begin{array}{l}+++ \\
20^{\circ}\end{array}$ & Ga ir & UCo & $\mathrm{mPu}$ & $\mathrm{Hy}, \mathrm{E}$ \\
\hline 15 & W & $150-200$ & $C N$ & $?$ & $?$ & $\mathrm{mu}$ & +++ & 0.49 & ? & UNU & $\mathrm{UCo}$ & $-^{+}$ & - \\
\hline 16 & W & 50 & $\mathrm{CN}$ & ? & $?$ & a & - & 1.12 & ? & Ga ir & $\mathrm{COH}$ & $\mathrm{mPu}$ & - \\
\hline 17 & $w$ & 50 & $\mathrm{CN}$ & 4.0 & 1.0 & ? & + & $f \mathrm{cl}$ & $19^{\circ}$ & Dr $\mathrm{Wa}$ & UCo & $\begin{array}{l}+++ \\
\text { bu }+\end{array}$ & - \\
\hline 18 & $w$ & $50-60$ & $C N$ & 2.5 & 0.5 & sa & - & $\mathrm{fcl}$ & ? & Dr Wa & Uco & ? & $\overline{\mathrm{Hy}}$ \\
\hline 19 & $w$ & 30 & $\mathrm{CN}$ & 2.5 & 0.5 & mu & +++ & 0.17 & $21^{\circ}$ & UNU & UCo & - & $\mathrm{E}$ \\
\hline 20 & $w$ & $30-40$ & $\mathrm{CN}$ & 2.5 & $0.3-0.4$ & $?$ & ++ & - & ? & UNU & $\mathrm{UCo}$ & - & $\mathrm{E}$ \\
\hline 21 & W & 30 & $C N$ & 2.5 & $0.3-0.4$ & $\mathrm{mu}$ & +++ & - & $?$ & UNU & UCo & - & $\mathrm{E}$ \\
\hline 22 & 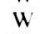 & 80 & $C N$ & 4.0 & ? & $\mathrm{mu}$ & +++ & - & ? & UNU & Co p & - & $\mathrm{E}$ \\
\hline 23 & SL & 0.5 & $\mathrm{BR} \mathrm{Pu}$ & $0.1-0.2$ & 0.2 & sa & + & 20.59 & ? & - & - & - & $\mathrm{E}, \mathrm{Hy}$ \\
\hline 24 & SL & 1.0 & Sau & 0.1 & - & sa & + & - & - & - & - & - & $\mathrm{E}, \mathrm{Hy}$ \\
\hline 25 & SL & 1.0 & $\mathrm{~K}-\mathrm{Ch}$ & $0.1-0.2$ & 0.2 & sa & + & 17.75 & ? & - & - & - & $\mathrm{E}, \mathrm{Hy}$ \\
\hline
\end{tabular}

Legend for Table 1.

I - type of the habitat (S.L.-Supralittoral, W-well); Il - approximate distance from the seashore in meters; III - sampling method (K-Ch. -Karamann-Chappuis pits, C.N.-Cvetkov net, C-core, P.N.-plancton net, B.R.Pu. - Bou-Rouch pump, Saw.-sand washed); IV - depth of the grounwater table; V -depth under the groundwater table from which the fauna has been sampled; VI - type of sediment (sa.-sand, pe.-pebble, si.-silt, mu-mud); VII -organic matter $(+++$ large quantities, + + moderate, + little, $\rightarrow$ no); VIII - chlorinity in g/1, fcl-fresh cleaned; IX temperature of the water in degrees Celsius; $X$ - use of the wells (UNU-unused, Ga.ir.-garden irrigation, Dr. Wa.-drinking water supply, Wa.S.-water supply for the cattle); XI -protection of wells (Co-covered, + + very well, ce-cement, W-wood, Uco-uncovered, Cop-poor covered); XII - Extraction of water, methods and quantities (NPu-Norton handpump, mPu-motor pump, bu-bucket, + moderate extraction, +++ intensive extraction); XIII - Fauna (Hy-hypogean, E-epigean). 
the wells (number 4 and 16) I found marine fossil ostracods, foraminifers, and gastropods besides the coarse sand. A core of $10 \mathrm{~cm}$ depth in the sediment of well number 3 showed that the main fraction is constituted by coarse sand. All these facts suggest that on the western coast of Euboea the aquifer is developed in marine sediments.

Guernet (1971) showed that Euboea was connected with the main land during the Miocene and the Pliocene. South from Gialtra (at about $10 \mathrm{~km}$ from the village Aghios Georghios), Guernet found a lacustrine deposit with typical freshwater miocene gastropods (2 species of Melanopsis), which supports the idea that the northwestern part of Euboea has emerged at least since the Miocene. Psarianos and Thenius (1953) mentioned the presence of Elephas meridionalis near Aedipsos. This suggests to Guernet (1971) that the island was isolated from the mainland during the Pleistocene, later than the Villafranchian.

The extension and shape of the lowland coast of Euboea varied most probably during the Pleistocene due to the rise and fall of the sea level in the Aegean area. Marine quarternary sediments are registered in the Zarka Valley on the eastern coast of Euboea at about $10 \mathrm{~m}$ altitude (Guernet, 1971). Lüttig and Steffens (p. 47, 1977) noticed that during the Pleistocene "the most radical changes in the Aegean area occurred during Tyrrhenian. Large regions in the central and northern parts foundered and were flooded by the sea. A marine connection reached the Euxinic Basin via the Sea of Marmara.",

The 20 wells I investigated are located near the coast between 19 and about $200 \mathrm{~m}$ in from the seashore. Most of the wells are located at an altitude below $1 \mathrm{~m}$ above sea level. The water table lies at a depth of 2 to $8 \mathrm{~m}$ below the surface of the ground. The porosity seems to be low, at least around the Biological Station at Keramou (Matsakis, pers.comm.). The chlorinity of the water varies between $0.07 \mathrm{mg} / 1$ and $1.27 \mathrm{mg} / 1$. Thus, in all the wells there is freshwater (see Table 1). The temperature of the water in the wells varies between 19 and $22^{\circ} \mathrm{C}$.

I also investigated marine sediments near the seashore in the supra littoral area and/or near the upper limit of the tide in the intertidal zone. The range between low and high tide levels represents about $6 \mathrm{~m}$. The chlorinity varies between 17.45 and $29.46 \mathrm{~g} / 1$.

The marine interstitial fauna have been collected using a BouRouch pump, digging pits and filtering the water (the Karaman-Chappuis' method). In these cases I extracted 5 liters of water. In one case I washed moist sand (1-2 liters; see table 1).

There are two types of wells: (1) Largely cased wells with a diameter of about 1-1.5 m (seldom $2 \mathrm{~m}$, well number 6 ), and (2) Norton pumps. The former have been sampled from outside with a Cvetkov net and sometimes inside with a plankton net. The latter have been sampled by filtering the pumped water through a plankton net (mesh $80 \mu \mathrm{m})$. All the samples are qualitative.

Most of the wells contain meio- and macrofauna. The 20 wells can be grouped into 6 types:

I - Norton pumps $(4,13)$ which are still in use and provide water for in- 
habitants. The water is clean and contains little particulate organic matter.

II - Large wells covered and well protected such that little organic matter accumulates from outside; the bottom is periodically cleaned. The water is used for drinking and is extracted moderately, sometimes using a motor pump. Such wells are number 5, 6, 17, and 18 .

III - Large wells which are no longer in use but are covered so that little pollution comes from outside (number 3 is an example).

IV - Large wells which are currently in use, the water being strongly pumped (with motor devices) for the irrigation of land and orchards (see well number 16).

V - Large uncovered wells, moderately used for irrigation; organic matter accumulates on the bottom (see well numer 14).

VI - Large wells, mainly uncovered, which are seldom in use for supplying water for the cattle, or which are no longer in use. Much organic matter accumulates on the bottom, which is muddy. The water temperature of these wells is $1-2^{\circ} \mathrm{C}$ higher than in the protected wells used for the drinking water supply. Such wells are numbers 7, 8, 9, 10, 11, 15, 19, 20, 21, 22.

\section{RESULTS (tables 1-3)}

The Norton pumps and the well which is intensively used for irrigation (the wells of type 1 and type 4 in table 2) contain no ostracods. This seems to be incidental in the type 1 wells as other hypogean animals could be found (Isopods, Microcerberus, and harpacticoids). No animals were found in type 4 wells, which might be a result of intensive pumping. The group of wells of type 2 and type 3 , considered as clean or slightly polluted, contain two interstitial (hypogean) ostracods: Mixtacandona pseudocrenulata described by Schäfer (1945) and Pseudolimnocythere hartmanni, a new species (see Danielopol, 1979).

The group of wells of type 5 and 6 with polluted bottoms contains mainly epigean species. Cypria lacustris Sars is the most abundant and the most common species in these wells (see table 2). It is followed by Cypridopsis newtoni (Br. and Rob.). Both species have been recorded by Stephanides (1948) in the wells of Corfu (see well number P 53a). Cypria lacustris occurs commonly in wells in Yugoslavia (Petkovski, 1976), in Romania (Danielopol, 1965), but also in epigean habitats (Petkovski, 1960). The carapace shape, the male copulatory organ, and the female genital lobe of the specimens from Euboea conform to those described by Petkovski (1960). Cypridopsis newto$n i$ seldom occurs in wells but is encountered mainly in permanent fresh or oligohaline water bodies, especially during summer and autumn (Klie, 1938 and 1941).

Besides Cypria lacustris, isolated specimens of Ilyocypris bradyi Sars occurred in the wells number 8 and 9. Many empty carapaces of Ilyocypris can also be found on the bottom of those wells. This suggests that in those wells where Cypria lacustris is predominant processes of competition with Ilyocypris bradyi could occur, finally affecting the exclusion of this latter ostracod. 
Table 2. Distribution of the ostracod fauna in the Euboea wells (numbers 3-22); I-VI type of wells (see text). The broken line delineates the main ostracod associations.

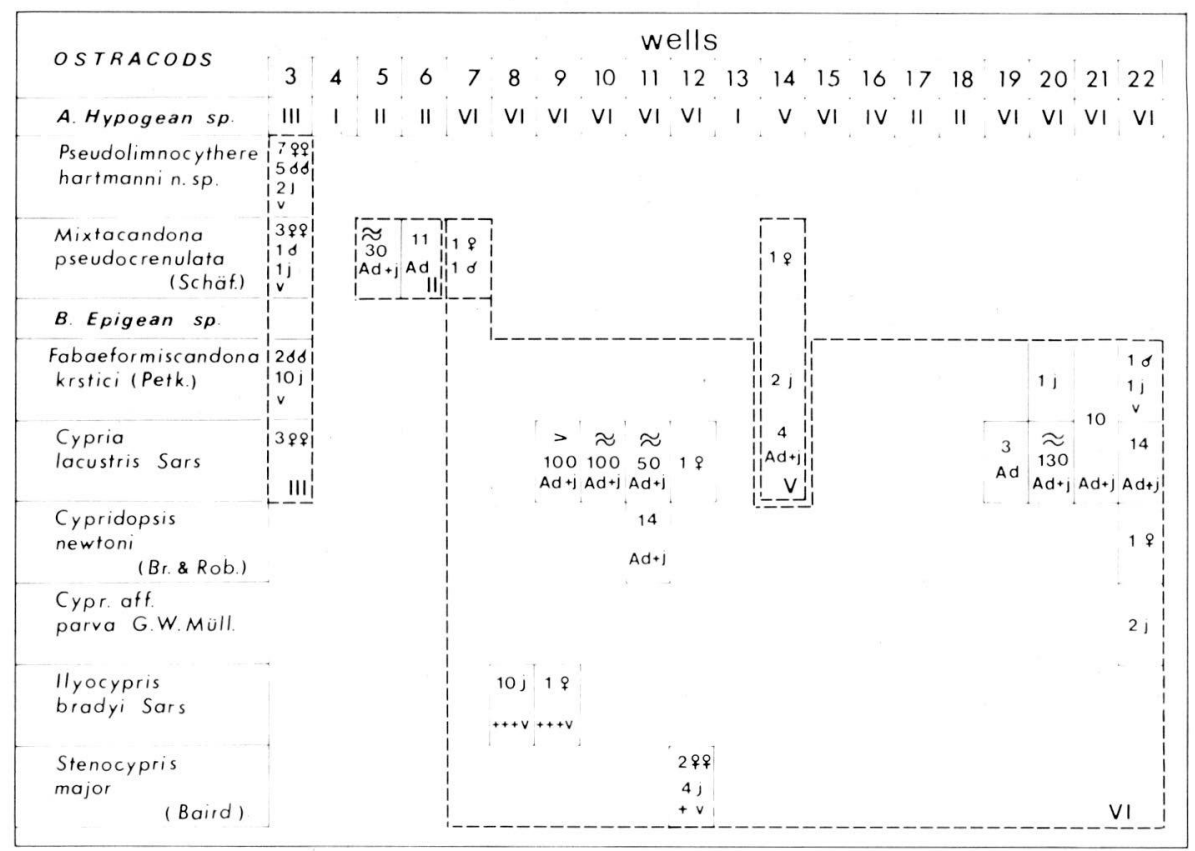

Fabaeformiscandona krstici (Petkovski, 1969) is an epigean species which has been described using living material from Ochrid Lake, Yugoslavia. Petkovski considers that this species also occurs in the Pleistocene deposits of the Liri Valley (see Devoto, 1965). The species is recorded in Greece for the first time.

Stenocypris major (Baird) is an epigean thermophilic species which has already been recorded in South and Central Europe (see Löffler and Danielopol, 1978). This species is recorded for the first time in a well (number 13) in Greece.

The wells of Euboea behave like island habitats, colonized by both epigean and hypogean species. The diversity is low. I used the Brillouin index for the ostracods, which follows the suggestion of Kaesler and Mulvany (1977, p. 33): “Brillouin's equation from information theory is well suited for studying diversity and community structure of recent and fossil ostracods. This equation gives the actual diversity per individual in a collection and not an estimate of the parametric diversity of an statistical universe. Because of the difficulties of defining the extent of the statistical universe from which samples of ostracods are drawn, study of collections in their own sake 
is to be prefered.' For instance, for well number 3, the Brillouin's diversity index is 0.48 (table $3 \mathrm{~B}$ ).

In shallow marine habitats of Baja California, Kaesler and Mulvany (1977) recorded a diversity index of the ostracod associations varying between 0.45 and 2 .

The wells that are uncovered are protected very little against the pollution from outside and those from which water is pumped intensively constitute ecologically unstable habitats.

Table 3A. Distribution of marine interstitial ostracods in the investigated area.

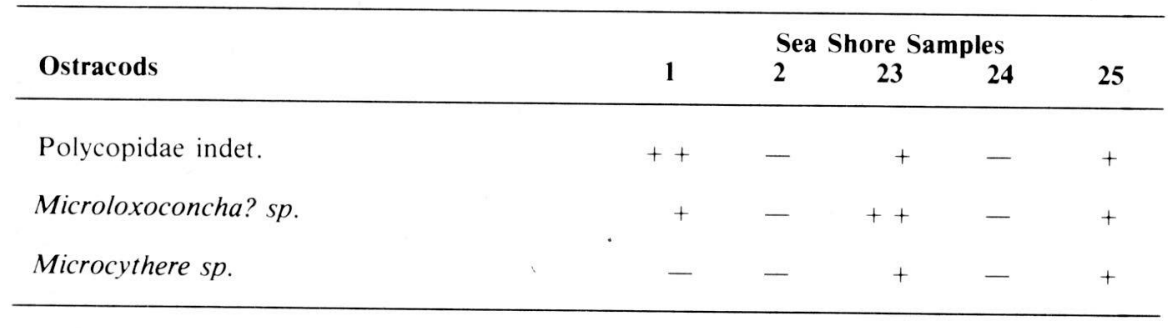

1,2,23-25 number of the sample sites (see table 1 e fig. 2 );

,+++ abundance of the ostracod species (see text also).

Table 3B. The ratio between hypogean and epigean ostracod species as percentage in wells 3,5 , 14,16 , and 22 .

\begin{tabular}{lccccc}
\hline Wells & 5-II & 3-III & 16-IV & 14-V & 22-VI \\
\hline Hypogean / Epigean $\%$ & $100 /$ & $56 / 44$ & 0 & $14 / 86$ & \\
$\mathrm{H}_{\text {Brillouin }}$ & & 0,48 & & \\
\hline
\end{tabular}

$\mathrm{H}_{\text {Brillouin }}$ - the diversity index computed (using the Brillouin's expression for the ostracod association of well number 3 . 
In the polluted wells (e.g., well number 22), the fauna are represented by epigean cosmopolitan forms: ostracods (Cypria lacustris), isopods (Asellus aquaticus), Culicidae and Chironomidae larvae which penetrate from outside.

In the unprotected wells from which water is taken moderately (e.g., well number 14), the abundance of the epigean fauna is higher than those of the hypogean, see ostracods in tables 2 and $3 \mathrm{~B}$.

In protected wells (covered outside) no longer in use, such as well number 3, the hypogean animals are more abundant than the epigean ones (tables 2 and 3B). Finally, in the protected wells used for drinking water supply (like the Norton pumps and well number 5), no epigeans are found (for the ostracods, see table 2 and 3B).

Ronneberger (1975) suggests that the ratio between the epigean and hypogean animals in the wells could be used as an index for their water quality. The present investigation confirms the validity of this assumption.

The interstitial ostracods found in the supralittoral near the upper limit of the tide level (sites 1, 23, and 25) are represented by a species belonging to the family Polycopidae and the interstitial species Cytheracea belonging to the genera Microloxoconcha? and Microcythere. These three ostracod groups have exclusively marine representatives. Most of them live in porous sediments of the littoral and the supralittoral zones (Hartmann, 1973).

At site 1 (see fig. 3A), the sediment consists of coarse sand and pebbles. The Polycopidae predominate characterized by long "swimming" antennal setae, whereas the creeping form Microloxoconcha? is rare. At sites 23 and 25 , the beaches have only coarse sand. In this habitat I found more Microloxoconcha? sp. and seldom Microcythere (another creeping form) and Polycopids.

The lack of freshwater ostracods (Cyprididae) mixed with these marine ostracods in the interstitial habitats near the seashore is striking. This could be due to the fact that the zone where subsurface marine and freshwaters mix is very narrow and does not allow the coexistence of freshwater and marine forms in some transitory brackish water environment as portrayed by Delamare-Deboutteville (1960). A similar pattern is displayed by other meioand macrofauna. At site 24, the marine interstitial halacarid Acarochelopodia sp. aff. delamarei occurs and the freshwater halacarid Lobohalacarus quadriporus is found in well number 3. Sample 24 also contains many Hesionides arenaria, Fried., a typical marine interstitial polychaet living in fine and coarse sands. The halacarids have been identified by Dr. T. Gledhill and the polychaets by Dr. L. Laubier.

One has to note the limited number of freshwater hypogean ostracod species (two species only) in the investigated area (about $15 \mathrm{~km}$ along the coast). It is often postulated that the groundwater habitats are highly stable and have a long temporal permanency (see interalia, Noodt, 1968).

In such time-stable habitats, a high diversity of fauna could develop (see the Sanders' stability-time hypothesis with examples from deep sea and Baikal Lake habitats; Sanders, 1969).

The northwestern coast of Euboea has a porous aquifer in the lowland 
which was most probably affected by the sea level fluctuations during the Pleistocene. If this view is accepted, the habitat I investigated does not have the time-stability attribute.

The low effective porosity seems to be responsible for the small size of the hypogean fauna (ostracods of 0.3-0.5 mm length). The presence of $\mathrm{Mi}$ crocharon (very common), Microcerberus, Ingolfiella petkovskii, Bogidiella skoplensis*, and the lack of larger Malacostraca, and hypogean Ostracoda like Niphargus, representatives, Proasellus sketi Henry, Pseudocandona and Candonopsis species, is striking.

A higher diversity of hypogean fauna can be expected in Greece on the mainland in habitats with a better porosity and a longer permanency. Such a habitat could be the porous aquifer of the Ladon Valley (station Gr.5, fig. 1) in Arcadia, where Bou (1975) found 5-6 species of hypogean amphipods in one place.

Finally, these data suggest that in the Mediterranean area the hypogean fauna could be easily found in protected wells, with little organic matter accumulated and where water is pumped moderately. This observation should be of some help to those who are interested in faunistic surveys. They always face the problem of selecting the wells that should be sampled with the hope of finding a rich hypogean fauna.

\section{CONCLUSIONS}

1) Mixtacandona pseudocrenulata, one of Schäfer's species found in Thessaly, was found in the porous aquifer of Euboea, which partly confirms my suspicion that the ostracods described by Schäfer live in an interstitial habitat.

2) The large wells in Euboea behave like island habitats which are colonized by both epigean and hypogean animals.

3) The hypogean ostracods live mainly in protected wells with little organic matter accumulation, where water is pumped moderately. The epigean ostracods predominate in uncovered wells with polluted water and rich inorganic matter.

4) The ostracod species found in some of the Euboea wells, like number 3 , form coherent associations in which the epigean species could be as important as the hypogean ones.

5) The data presented above reinforce the suggestion of Ronneberger (1975) that the ratio between epigean and hypogean animals in wells could be used as an environmental index to show the degree of pollution in the wells. Further investigations are needed to demonstrate how the pollutants and/or epigean fauna eliminate hypogean fauna from wells.

6) The low number of hypogean ostracods in the area investigated could be due either to the instability of the well habitats on an ecological time scale

* Species found in Greece for the first time (det Cl. Bou). 
or to the instability of the coastal aquifer at an evolutionary time scale.

7) The presence of exclusively small size hypogean ostracods could be due to the fine grained sediment.

8) There is a sharp difference between the marine interstitial ostracods found in the supralittoral zone of the Euboea coast and those of the wells inland.

9) Finally, these data suggest that in the Mediterranean realm the hypogean fauna could be found easily in wells with little accumulation of organic matter, where water is pumped moderately.

\section{ACKNOWLEDGEMENTS}

I am greatly indebted to the following colleagues who helped during the completion of this project: J. Th. Matsakis, director of the Biological Station Keramou, Cl. Bou (Albi), N. Coineau (Banyuls s. Mer), T. Gledhill (East Stoke), Cl. Guernet (Paris), J.-P. Henry (Dijon), Fr. LecherMoutoué (Moulis), L. Laubier (Brest), H. Löffler (Wien), F. Rögl (Wien), R. Rouch (Moulis), F. Steiniger (Wien) and P. Steffens (Hannover).

\section{RÉSUMÉ}

La faune dulçaquicole de 20 puits localisés à 15-200 mètres du rivage, de même que la faune marine interstitielle, ont été prospectées dans la zone côtière autour du village Aghios Georghios (Cap Likhada, île d'Eubée). Les Ostracodes hypogés d'eau douce vivent principalement dans les puits couverts, dont le fond est propre et pauvre en matiéres organiques et dont l'eau est pompée modérément. Les Ostracodes épigés d'eau douce prédominent dans les puits à l'air libre, avec de grandes quantités de matière organique sur le fond. Une différence accusée existe entre la faune ostracodologique vivant en eaux douces souterraines (principalement des Cyprididés) et celle des habitats interstitiels marins côtiers (Cythéridés et Polycopidés marins). On peut penser que dans le domaine méditerranéen, la faune hypogée pourrait être le plus aisément découverte dans les puits couverts, où l'accumulation de matière organique est faible et dont l'eau est modérément pompée.

\section{REFERENCES}

BOU, Cl. 1974. Observations sur les Ingolfiellides (Crustacés Amphipodes) de Grèce. Biol. Gallo.-Hellen. 2(1):57-70.

BOU, Cl. 1975. Rechèrches sur la faune des eaux souterraines de Grèce. Biol. Gallo.-Hellen. 6(1):101-116.

COINEAU, N. 1969. Isopodes interstitiels de l'île d'Eubée, Grèce. Biol. Gallo.-Hellen. 3(1):99103.

DANIELOPOL, D. 1965. Nouvelles données sur les ostracodes d'eau douce de Roumanie. Ann.Limnol., Toulouse, 1:443-468.

DANIELOPOL, D. 1971. Quelques remarques sur le peuplement ostracodologique des eaux douces souterraines d'Europe, in: Paléoécologie des ostracodes, OERTLI H.J., Ed., Bull. Centre Rech.S.N.P.A., Pau, suppl. 5:179-190.

DANIELOPOL, D. 1977. On the origin and diversity of European freshwater interstitials ostracods, in: Aspects of Ecology and Zoogeography of Recent and Fossil Ostracoda, LÖFFLER H. and DANIELOPOL D. Eds., Junk BV, The Hague: 295-305.

DANIELOPOL, D. 1979. On the origin and the antiquity of the Pseudolimnocythere species (Ostracoda, Loxocondidae), in: The 1st Congress on Ecology and Zoogeography of Greece, MATSAKIS, J., Ed., Biol. Gallo.-Hellen. 8:99-107. 
DELAMARE-DEBOUTTEVILLE, Cl. 1960. Biologie des eaux souterraines littorales et continentales. Hermann, Paris.

DEVOTO, G. 1965. Lacustrine Pleistocene in the lower Liri Valley Southern Latium. Geologia Romana 4:29-368.

GUERNET, Cl. 1971. Études géologiques en Eubée et dans les régions voisines (Grèce), Thèse, Univ. Paris.

HARTMANN, G. 1973. Zum gegnwärtigen Stand der Erforschung der Ostracoden interstitieller Systeme. Ann. Spéléol. 28,3:417-426.

KAESLER, R.L. and MULVANY, P.S. 1977. Approaches to the diversity of assemblages of Ostracoda, in: Aspects of Ecology and Zoogeography of Recent and Fossil Ostracoda, LÖFFLER H. and DANIELOPOL D. Eds., Junk BV, The Hague: 33-44.

KLIE, W. 1938. Ostracoda, Krebstiere oder Crustacea III, Muschelkrebse, in: Die Tierwelt Deutschlands, DAHL, 37:1-230.

KLIE, W. 1941. Süßwasserostracoden aus Südosteuropa. Zool.Anz. 133,11/12:233-244.

LÖFFLER, H., and D. DANIELOPOL. 1978. Ostracoda, in: Limnofauna Europaea ILLIES J., Ed., G. Fischer Verl., Stuttgart:196-208.

LÜTTIG, G., and P. STEFFENS. 1977. Explanatory notes for the paleogeographic atlas of Turkey from the Oligocene to the Pleistocene. Hannover:1-64.

MATSAKIS, J.Th. 1975. Apercu général sur la région et premier bilan relatif à la faune terrestre et dulcaquicole. Biol. Gallo.-Hellen. 6,1:117-124.

NOODT. W. 1968. Deuten die Verbretungbilder reliktärer Grundwasser-Crustaceen alte Kontinent-Zusammenhänge an?. Naturw. Rdsch. 11:470-476.

PETKOVSKI, T. 1960. Zur Kenntnis der Crustaceen des Prespasees. Fragm. Mus. Maced. Sc. Nat. 3,15:117-131.

PETKOVSKI, T. 1969. Einige neue und bemerkenswerte Candoninae aus dem Ohridsee und einigen anderen Fundorten in Europa (Crustacea-Ostracoda). Acta. Mus. Maced. Sc. Nat. 11,5:81-110.

PETKOVSKI, T. 1976. Zwei neue und eine seltene Ostracoden-Art der Gattung Cypria Zenker aus Jugoslawien. Acta. Mus. Maced. Sc. Nat. 14, 7:173-192.

PSARIANOS, P., and E. THENIUS. 1953. Über Elephas (Archidiskodon) meridionalis (Eleph. Mammal) von Euböa (Griechenland). Prak. Akad. Ath. 28:413-424.

RONNEBERGER, D. 1975. Zur Kenntnis der Grundwasserfauna des Saale-Einzugsgebietes (Thüringen). Limnologica (Berlin) 9,3:323-419.

SANDERS, H. 1969. Benthic marine diversity and the stability time hypothesis, in: Diversity and Stability in ecological systems, Brookhaven Symposia in Biology WOODWELL C. and SMITH H., Eds. Springfield, nr. 22:71-81.

SCHÄFER, H.-W. 1945. Grundwasser-Ostracoden aus Griechenland. Arch.f.Hydrobiol. 40,4: $847-866$.

SCHÄFER, H.-W. 1951. Über die Besiediung des Grundwassers. Verh. Int. Verein. Theor. Ang. Limnol. 11:324-330.

STEPHANIDES, Th. 1948. A survey of the freshwater biology of Corfu and of certain other regions of Greece. Publ. Hellen. Hydrobiol. Inst. II. 2:1-251.

YANNOPOULOS, C., and J.-M. BARROIS. 1975. Ecologie marine de la région d'Eubée du Nord. I Donées préliminaires sur le zooplancton et l'ichthioplancton. Biol. Gallo.-Hellen. 6,1:125-134. 



\title{
Phreatische Fauna in Ljubljansko polje (Ljubljana-Ebene, Jugoslavien) - ihre ökologische Verteilung und zoogeographische Beziehungen
}

\author{
B. Sket* und F. Velkovrh*
}

\begin{abstract}
SUMMARY
The phreatic basin of Ljubljansko polje (polje = plain, field) recharges its water supply mainly from the Sava river-bed and at a few other locations where connections with karstic subterranean waters might exist and only up to $15 \%$ from precipitation. An important zone of infiltration in the river-bed is the bottom and not the bank which is to a large extent watertight due to organic debris (rests of Sphaerotilus e.g.). The main water-body moves about $10 \mathrm{~m} / \mathrm{day}$, there are however some local jets with far higher speeds.

Yearly amplitudes of water temperatures are high near the river but in the center of the plain only a couple of centigrades. Oxygen saturation is in the open river-water $100 \%$, dropping to 40 $60 \%$ just $1 \mathrm{~m}$ into the phreatic.

True stygopsammal animals are represented here only by a few species and specimen in spite of the fact, that the interstices in the gravel are mostly filled with finer sediments. Remarkable is also the scarcity of Nematodes and the near absence of Acarina (compare with Danielopol 1976).

Only a few specimen of the river benthos (Chironomidae, Tipulidae, Leuctra supp., Baetis spp.) penetrate the interstitial water (compare with Ruffo 1961, Danielopol 1976) and only Naididae are more frequent there. However, many epigean animals occur in interstitial waters in the periodically flooded gravel-banks; one can explain this with oscillations of the water level. Some epigean animals (creno- and troglophilic) are quite regularly represented in the phreatic near the river, but have not been found in the river-bed.

The distribution of phreatic species within the studied water-body seem to be controlled mainly by the presence of food supplies and the consequent competition among species. The same is true for the speed of the water current and some other factors which are less easily defined. The characteristics of the substratum as well as $\mathrm{O}_{2}$-saturation and other characteristics of the water seem to have little influence on the fauna.

The energetically (food-) rich neighbourhood of the river is inhabited by a number of species in quite dense populations while the central parts of the phreatic water body exhibit a great poverty of species and of specimen. However, some species live here, which don't occur in the presence of larger food supplies - and of greater competition (Niphargus serbicus). The higher current speed seems to prevent settlement of some species (Cyclopoida, Proasellus deminutus) while some are bound to such habitats (Proasellus vulgaris).

Some species exhibit a high degree of euryvalency inside the stygopsephale habitats (Niphargus longidactylus e.g.), while some are highly specialized. Some of them form dense populations (comparatively dense even in energetically poor places) while others exhibit even in most favourable conditions very low densities (Niphargus jovanovici multipennatus).
\end{abstract}

The present fauna is zoogeographically very diverse. Some species are distributed throughout

* Institut za biologijo Univerze und Biotehniska fakulteta, YU 61001 LJUBLJANA, pp. 141, Yugoslavia.

Die Untersuchungen wurden von Raziskovalna skupnost Slovenije (Research Council of Slovenia) finanziell unterstützt. 
Europe; some reach from Central Europe to the borders of Dinaride Karst (Bogidiella albertimagni) and some even penetrate it (Trichodrilus pragensis, Acanthocyclops kieferi). Bogidiella semidenticulata, Niphargus pectinicauda, Hadziella deminuta seem to be limited to the higher reaches of the Sava River. All of the above mentioned animals live regularly in interstitial waters and only sporadically in karstic hypogean waters.

Niphargus stygius is here the only animal of a certainly karstic provenience; inside the plain it is limited to a completely special habitat. It is very likely that the entire Proasellus-deminutusgroup has developed in interstitial waters of larger plains which are in contact with karstic areas; some species penetrated from the plains into the karst rather than the reverse. To the contrary (judging from the distribution of the genera) karstic waters seem to be the cradle of Hauffenia and Hadziella. Such a sharp delimitation between cave- and interstitial fauna resp. in this area is very noteworthy. Both faunas live here in abundance and in close contact. It is very probable that particularly high competition and specialization of both faunas, caused by their richness and diversity, prevent mixing of species.

\section{EINLEITUNG}

Das Ljubljansko polje (polje = Feld, Flur, Ebene!) ist eine junge, tektonische, angefüllte, vorwiegend im Pleistozän entstandene Einsenkung, deren Boden wasserundurchlässige permo-karbonische Schiefer und Sandsteine bilden. Es hat die Form einer Schüssel, die in der Mitte fast $100 \mathrm{~m}$ und am Nordrande längs des Sava-Flusses 10 bis $20 \mathrm{~m}$ tief ist. Die ganze Einsenkung ist mit karbonatreichem Schotter und Sand ausgefüllt. Die unteren, pleistozänen Schichten sind teilweise konglomeriert. Die obersten, holozänen Schotterschichten sind mit einer verschieden dicken Humusdecke versehen, die teilweise bewaldet und teilweise landwirtschaftlich bearbeitet ist, auf einem grossen Teil aber bebant und mit einer wasserundurchlässigen Asphaltdecke bedeckt ist. Die Länge des Ljubljansko polje beträgt etwa 15 und die Breite bis etwa 5 km; es zieht sich in der Richtung WNW-OSO (Breznik 1969, Zlebnik 1971).

Das Gebiet ist als Zentrum Sloveniens besonders in den letzten Dezenien grossen Veränderungen unterworfen worden. Zur natürlichen, allmählichen Einsenkung des Flussbettes in die stellenweise schon undurchlässige, permokarbonische Unterlage (Verkleinerung der Infiltrationsflächen) gesellen sich der Ausbau der Industrie flussaufwärts von Ljubljana und die wachsende Stadtpopulationen (starke anorganische und organische Verunreinigung), die Erweiterung der Stadtfläche (verkleinerte Fläch’en für die Infiltration des Regenwassers in das Grundwasser), der Ausbau der Reinigungsanlagen in allerletzter Zeit (eine sekundäre Verbesserung des Sava-Wassers), der erhöhte Grundwasserverbrauch (Erniedrigung des Grundwasser-Spiegels). Überdies verursachen die Wasserkraftwerke oberhalb Ljubljana kurzdauernde (manchmal tägliche) aber starke Verănderungen des Wasserstandes und der Wasserqualität.

Das Ljubljansko polje ist von fast allen Seiten von niedrigen, aus Schiefer- bzw. Sandsteinen bestehenden Bergen umgeben. Doch ein enger und seichter Schottergürtel zieht sich längs des ganzen Sava-Tales in Slovenien, der auch mehrere kleinere Karst-Massive berührt oder sogar überquert. Es existiert also wenigstens ein indirekter Kontakt des Grundwassers mit den unterirdischen Karstgewässern. Obgleich die Grundgewässer des Ljubljansko 


$$
3
$$


polje selbst vom Massiv des Dinarischen Karstes etwa lo km entfernts sind, könnte diese Bresche an zwei Stellen (im W und SO) überbrückt sein. Die verkarstungsfähigen Konglomeratschichten sind an diesen Stellen nähmlich den wenigstens schwach verkarsteten, inselartigen Kalkstein- bzw. Dolomitmassiven genähert oder mit ihnen sogar unterirdisch verbunden.

Unsere Untersuchungen - als erste intensivere Grundwasseruntersuchungen in Slovenien - sind schon im Jahre 1955 begonnen worden, doch waren sie damals nur faunistisch orientiert. Später haben wir intensiver die Dynamik der Tierpopulationen im ergiebigen Norton-Brunnen am Dovjez studiert, sowie etwas genauer die Verbreitung der Tiere in verschiedenen Teilen und Habitaten im Rahmen der Ebene. Wir haben die verschiedensten Sammelmethoden für die unterirdische Tiere angewandt (Filtrieren des Wassers aus Nortonbrunnen und Bohrungen, Karaman-Chappuis-Methode, BouRouch-Sonde, Cvetkov-Netz usw.). Den chemischen Untersuchungen haben wir dagegen vielleicht zu wenig Aufmerksamkeit gewidmet.

Mit der BR-Sonde haben wir das Grundwasser an jeder Stelle von einer Tiefe von $50 \pm 10 \mathrm{~cm}$ (im Flussbett) bzw. $20 \pm 10 \mathrm{~cm}$ (am Ufer) sowie von etwa $80 \pm 10 \mathrm{~cm}$ (in beiden Fällen) gepumpt (Abb. 2). Das Grobe Schotter ermöglicht tiefere Einsenkung der Röhre nicht. Die Menge des gefilterten Wassers wurde immer ausgemessen, das Verhältniss Wassermenge/Tierzahl kann uns aber keinen absoluten Wert der Besiedlungsdichte zeigen.

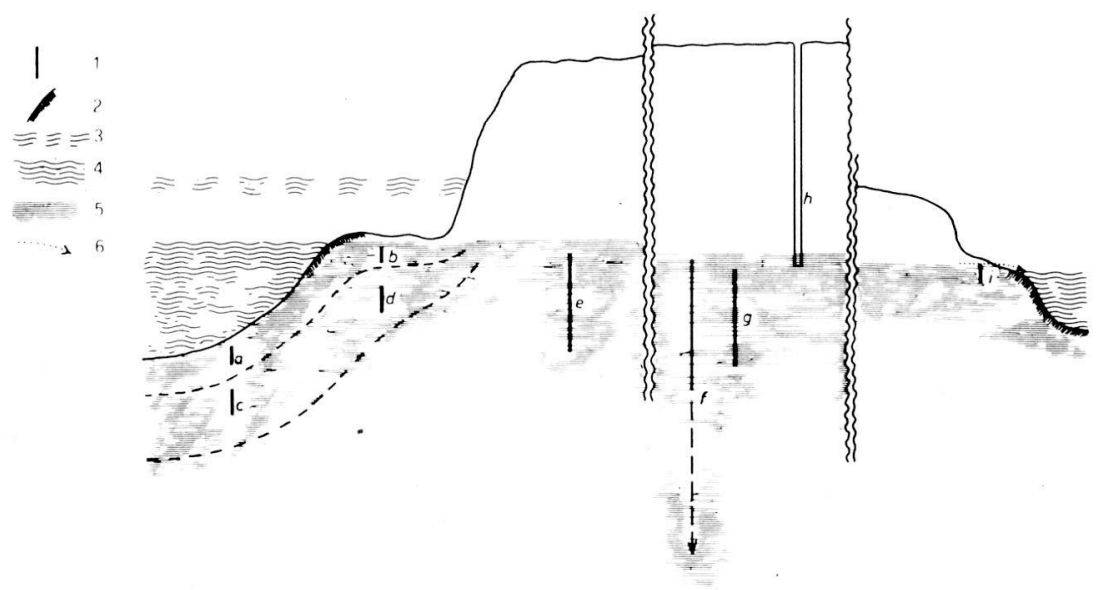

Abb. 2. Skizze der Sonden; 1 - Sonde (a-d - Bou-Rouch- und Karaman-Chappuis-Sonden im Bettboden und im Ufer, e - Nortonbrunnen in der Uferterrasse, $\mathrm{f}-\mathrm{g}$ - Tiefbohrungen und Nortonbrunnen im Inneren der Ebene, $h$ - Schachtbrunnen, i - BR-Sonde an der Ausflussquelle), 2 - wasserundurchlässige Uferzone, $3^{*}-4$ - Flusswasser, während des hohen und des niedrigen Wasserstandes (links Sava, rechts Ljubljanica), 5 - Grundwasser, 6 - Ausflussquelle. 


\section{HYDROGRAPHISCHE VERHÄLTNISSE}

Das Grundwasserbassin des Ljubljansko polje füllt sich vorwiegend durch die Schotter aus dem Flussbett in der NW-Ecke der Ebene. Kleinere Wassermengen gelangen hieher von einigen anderen Stellen längs des Sava-Flusses sowie vom Süden. Der Gesammtdurchfluss des Grundwassers wurde im ausgesprochen trockenem Herbst 1967 mit 1400 1/sec berechnet. Das Wasser erneuert sich mit Regen nur etwa mit $15 \%$. Der Grundwasserspiegel ist etwa gleich dem Spiegel des Sava-Flusses, dies Stromrichtung ist der des Sava-Flusses parallel. Die stromgeschwindigkeit des Grundwassers beträgt nur $10 \mathrm{~m} / \mathrm{Tag}$. Bis zu 75\% des Grundwassers wird in der Trockenperiode vom Wasserwerk der Stadt Ljubljana sowie von anderen Verbrauchern in der Mitte der Ebene ausgepumpt, der Rest des Grundwassers trit aber in mehreren Quellen am O-Ende der Ebene zutage (Breznik 1969).

Das Boden des Flussbettes ist vorwiegend aus Schotter bestehend, an seichten Uferstellen und in kleineren Einbuchtungen lagert sich Sand bzw. Detritus ab. Unsere Grundwasseruntersuchungen zeigen, dass das Wasser aus dem Sava-Flussbett an sanft geneigten Uferstellen sowie an seichten Stellen des Bett-Bodens jetzt nicht in die Schotterablagerungen eindringen kann. Ständige vom Wasserkraftwerk verursachte Wasserspiegeloszillationen hatten nähmilich eine Verdichtung der Lücken mit organischem Material (Sphaerotilus-Matten, Detritus) zur Folge. Als Infiltrationszone kommt also nur der tiefere Flussbettboden in Betracht, wo der Schotter ständig in Bewegung ist un wo er sich dadurch ständig reinigt. Weil das Flussbett stellenweise ziemlich stark geneigt ist, bildet das Grundwasser auch kleinere, vom Flusswasser unabhängige Strahlen, die, nur meterweit vom Flussrand entfernt, einen höheren oder niedrigeren Wasserspiegel als das Fluss an der nächsten Stelle, haben können. Die erwähnte verdichtete Isolationsschicht ist äusserst dünn und grenzt landwärts manchmal an sehr grosslückigen Schotter.

Die Schotterablagerungen des Ljubljansko polje, durch welche der Hauptstrom des Grundwassers fliesst, sind zwar mit Sand gemischt, scheinbar aber füllt der Sand auf fast keiner uns zugänglichen Stelle die Lücken vollkommen aus, so dass man das Habitat als eine Kombination des Stygopsephals und Stygopsammals bezeichnen könnte.

Die Quellen am Ostende des Ljubljansko polje springen teilweise aus leicht verkarsteten Konglomeratschichten, die aber wieder mit Schotter bedeckt sein können.

\section{EIGENSCHAFTEN DES WASSERS}

Das Gerbigsfluss Sava hat grosse Stromgeschwindigkeiten. Obgleich das Sava-Wasser längs des Polje mit schwankenden, aber mehrmals sehr hohen Mengen verschiedener Pollutanten verunreinigt ist, sind hier die $\mathrm{O}_{2}$ Verhältnisse sehr günstig. Bei verhältnissmässig niedrigen Temperaturen (etwa $5-17^{\circ} \mathrm{C}$ ) schwankt das $\mathrm{O}_{2}$-Deficit von 0 bis ausnahmsweise $30 \%$.

Über die Verteilung bzw. Verbrauch des Sauerstoffes im Grundwasser 
belehren uns sehr gut die Verhältnisse, die im Sommer (August 1978) während der Übersättigung des Sava-Wassers festgestellt wurden. Nur an seltenen Stellen im Flussbett sowie am Ufer erreicht bei etwa $50 \mathrm{~cm}$ Tiefe (im Substrat) die Sättigung 80-100\%, wahrscheinlich handelt sich hier um die Stellen, wo das Flusswasser intensiver in die Unterlage infiltriert. Sonst erträgt die $\mathrm{O}_{2}$ Sättigung des Grundwassers so unter und neben des Flussbettes, wie auch im Inneren der Ebene etwa 40-60\%. Eine ausgesprochen Sauerstoffarme Grundwasser-Schicht (vergleiche Husmann 1972) um das Flussbett wurde hier also nicht festgestellt. Auch die Verhältnisse in fliessenden Wasserstrahlen neben des Flusses scheinen keine Abweichungen davon zu vorstellen. In der Ausflussquelle im Osten des Feldes ist die Sauerstoff-Sättigung dagegen auf $75 \%$ erhöht.

Organische Detritus-Teilchen sind im Interstiziellwasser um das Flussbett ziemlich unregelmässig verteilt. Die Masse des Detritus kann bis zu metertief im Grundwasser von der Gesammtmasse der Tiere viel grösser aber auch etwas kleiner sein. In den Proben aus der Nortonbrunnen so längs des Flusses, wie auch im Inneren der Ebene haben wir dagegen kein Detritus mehr bekommen.

Die Menge der organishen Stoffe im Flusswasser ist sehr grossen Schwankungen unterworden. Der $\mathrm{KMnO}_{4}$-Verbrauch erreicht 2-60 mg/1, $\mathrm{BSB}_{5} 2-10 \mathrm{mg} / 1$. Bis zur Pumpstellen des Wasserwerkes erniedrigen und stabilisieren sich diese Werte auf etwa $2-5 \mathrm{mg} / 1 \mathrm{KMnO}_{4}$-Verbrauch und $\mathrm{BSB}_{5}$ von $0,3-0,8 \mathrm{mg} / 1$.

Die $\mathrm{NO}_{3}$-Menge scheint sich aber gegen die Pumpstelle (im Vergleich zum Flusswasser) zu vergrössern. Das ist im Einklang mit den Verhältnissen in den unterirdischen (also pflanzenlosen) Teilen der Sinkflüsse im Karste (Sket and Velkovrh 1981), stimmt aber nicht mit den Resultaten anderer Grundwasserforscher (Husmann 1972, 1975) zu, die vielleicht an stagnierenden oder flusswärts fliessenden Grundgewässern gearbeitet haben. Den Einfluss der Feld-Düngung auf den $\mathrm{NO}_{3}$-Gehalt des Grundwassers in Ljubljansko polje kann man selbtverständlich auch nicht ausschlüssen.

Die Temperatur-Amplitude des Sava-Wassers erreich hier etwa $15^{\circ}$ (kontinuierte Messungen nicht ausgeführt!) um einen Mittelwert von etwa $10^{\circ} \mathrm{C}$. Derselben jährlichen Temperaturschwankungen sind auch die Grundgewässer um das Flussbett (Nortonbrunnen in der Terrasse eingeschlossen) unterworfen. Auch die täglichen Schwankungen, die im Haurtstrom im Sommer etwa $6^{\circ}$ erreichen, sind in dem Bett und Seichtufer-Grundwasser noch ebenso hoch, nicht aber in den erwähnten Nortonbrunnen. Das Grundwasser in seichten Schotterbänken hat an der Oberfläche während der sonnigen Tage sogar um ein Paar Grad höhere Temperaturschwankungen. Das Grundwasser im Inneren des Feldes hat eine jährliche Amplitude von etwa $2^{\circ}$, um das Mittelwert von $11^{\circ} \mathrm{C}$.

\section{VERTEILUNG DER FAUNA}

Das aus grobem Schotter bestehende Stromgrund ist nur mit verschiedenen 
Algen (Cyanophyta, Bacillariophyta, Chlorophyta; stellenweise Sphaerotilus bis $20 \%$ der Bodenfläche) bewachsen. Von Tieren sind am zahlreichsten die Chironomidae-L. vertreten, weiter Gammarus fossarum Koch, Oligochaeta (Nais sp., Pristina spp. und Stylodrilus heringianus Claparede) und Leuctra spp. (Matoniĉkin und all. 1975, eigene Untersuchungen).

Selbstverständlich leben in dezimetertiefen Schichten des Schotterbodens regelmässig noch benthische Tiere, so vor allem Naididae, weiter

Tab. 1. Verteilung der Tiere in verschiedenen Habitaten (a-d, f-i - Bezeichnung wie in der Abb. 2; e - Nortonbrunnen am Dovjeẑ); in senkrechten Kolonen bedeutet die erste Nummer die Regelmässigkeit des Auftretens (1 - in vereinzelten Proben, $2- \pm$ regelmässig auftretend), die zweite die Zahl der Exemplare pro Probe (1 - vereinzelt, 2 - je bis 10 Exemplare, 3 - zahlreich bis massenhaft) $\left({ }^{+}\right.$nicht dieselbe Formen wie unter a-d).

\begin{tabular}{|c|c|c|c|c|c|c|c|c|c|}
\hline & a & b & c & d & e & f & g & h & $\mathbf{i}$ \\
\hline Nematodes gg.spp. & $2-1$ & $2-3$ & $2-2$ & $1-1$ & 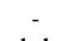 & - & - & - & -1 \\
\hline $\begin{array}{l}\text { Hadziella deminuta Bole } \\
\text { Hauffenia cf. michleri Kuŝcer }\end{array}$ & - & - & - & - & $1-1$ & - & - & - & - \\
\hline $\begin{array}{l}\text { (c,e,h) u. H.cf.erythropomatia } \\
\text { (Hauffen) (i) }\end{array}$ & - & - & $1-1$ & - & $1-1$ & - & - & -+ & -1 \\
\hline $\begin{array}{l}\text { Belgrandiella kuesteri Boeters } \\
\text { u. B.fontinalis (Schmidt) }\end{array}$ & - & $1-1$ & - & $1-2$ & - & - & - & - & -3 \\
\hline Bythinella schmidti (Küster) & $1-1$ & $2-2$ & $2-2$ & $2-2$ & - & - & - & - & -1 \\
\hline Naididae gg.spp. & $2-3$ & $2-2$ & $2-3$ & $1-1$ & - & - & - & - & - \\
\hline Oligochaeta (ex.Naididae) & $2-3$ & $2-3$ & $2-3$ & $2-3$ & $2-1$ & $2-1$ & $\therefore$ & $1-2$ & - \\
\hline Cyclopoida gg.spp. & $1-2$ & $2-3$ & $2-3$ & $2-3$ & $2-3$ & $?$ & $1-1$ & $1-2$ & - \\
\hline Harpacticoida gg.spp. & - & - & $1-1$ & - & $1-1$ & ? & - & - & -1 \\
\hline Ostracoda gg.spp. & - & $1-3$ & $1-1$ & $1-3$ & $2-1$ & ? & - & $1-1$ & - \\
\hline Bathynellacea gg.spp. & - & - & - & - & $1-1$ & $?$ & $1-1$ & - & - \\
\hline Proasellus deminutus (Sket) & - & - & $1-3$ & $2-3$ & $2-3$ & - & $1-1$ & - & - \\
\hline $\begin{array}{l}\text { P.vulgaris (Sket) (nur an } \\
\text { lenitischen Stellen) }\end{array}$ & - & - & $1-3$ & $1-3$ & - & - & - & - & -1 \\
\hline P.pavani orientalis (Sket) & - & - & - & - & $1-1$ & $1-1$ & - & $1-1$ & - \\
\hline Niphargus s.ljubljanensis Vodnik & - & $2-2$ & $2-1$ & $2-2$ & $1-1$ & - & - & $1-3$ & - \\
\hline N.stygius valvasori S.Karaman & - & - & $\therefore$ & - & - & - & - & $1-1$ & -2 \\
\hline N.longidactylus Ruffo & $1-2$ & $1-1$ & $2-3$ & $2-3$ & $2-3$ & $2-3$ & $1-1$ & $1-3$ & -2 \\
\hline N.pectinicauda Sket & $1-1$ & $1-2$ & $2-2$ & $2-3$ & $2-2$ & $1-1$ & $1-1$ & - & - \\
\hline N.pupetta (Sket) & - & - & - & - & $1-1$ & - & $1-1$ & $1-2$ & -1 \\
\hline N.serbicus S.Karaman & - & - & - & - & - & $1-1$ & $1-1$ & $1-1$ & -1 \\
\hline N.jovanovici multipennatus Sket & - & - & - & - & $2-2$ & $2-1$ & $2-1$ & $1-1$ & -1 \\
\hline Bogidiella spp. & - & - & - & - & $2-2$ & ? & $1-1$ & $1-1$ & - \\
\hline Chironomidae-1. & $2-2$ & $1-2$ & $2-1$ & $1-1$ & - & - & - & $1-2^{+}$ & - \\
\hline Tipulidae-1. & $1-1$ & $1-1$ & $1-1$ & - & - & - & - & $1-1^{+}$ & - \\
\hline Leuctra-1. & $1-1$ & - & $1-1$ & - & - & - & - & - & - \\
\hline $\begin{array}{l}\text { Stygoxene Formen (Pisidium, } \\
\text { Erpobdella, Lymnaea, Helmidae) }\end{array}$ & - & $2-1$ & - & - & - & - & - & $2-2^{+}$ & - \\
\hline Menge des Wassers pro Probe in $l$ & 30 & $\begin{array}{c}50 \\
\text { bis } \\
200\end{array}$ & 30 & $\begin{array}{l}40 \\
\text { bis } \\
80\end{array}$ & $\mathrm{~lm}^{3}$ & $\begin{array}{c}1000 \\
\mathrm{~m}^{3}\end{array}$ & & & \\
\hline $\mathrm{O}_{2}$-Sättigung in $\%$ (Sommer) & $\begin{array}{c}60 \\
\text { bis } \\
100\end{array}$ & $\begin{array}{l}40 \\
\text { bis } \\
80\end{array}$ & $\begin{array}{l}30 \\
\text { bis } \\
40\end{array}$ & $\begin{array}{c}30 \\
\text { bis } \\
50\end{array}$ & $\mathrm{x}$ & 50 & $\mathrm{x}$ & $\mathrm{x}$ & 75 \\
\hline
\end{tabular}


Chironomidae-L., Tipulidae-L., Leuctra-L.; die Insecten-Larven kommen aber nie in einer bedeutenderen Zahl vor. Copepoden sind hier selten, $\mathrm{Ni}$ phargen kommen nur stellenweise vereinzelt vor, andere unterirdische Tiere sind noch abwesend. Gegen metertief im Flussboden veränderen sich stellenweise die Verhältnisse zugunsten der stygobionten Tiere. Auch Cyclopoida kommen da schon massenhaft vor, Niphargus longidactylus bildet ziemlich dichte, $N$. pectinicauda spärlichere populationen, ebenso $N$. longicaudatus ljubljanensis; Proasellus deminutus ist ziemlich regelmässig vorhanden. Auch vereinzelte Insektenlarven leben noch hier. An den Stellen, wo diese ausgeprochen selten und Naididae sp̈ärlicher vertreten sind, kommt Proasellus schon massenhaft vor.

Auch im Grundwasser der seichten Ufer kommen in der Nähe des Wasserspiegels regelmässig benthische Tiere vor, obgleich dieses Wasser während des niedrigen Wasserstandes nicht sehr direkt mit dem Flusswasser verbunden ist. Scheinbar sind dies die Tiere, die während des rückziehens des Hochwassers in die Schotterbänke eindringen und da wegen der guten Ernährungverhältnisse überleben können. So findet man hier sogar die Arten, die im Stromm nicht aus dem Benthos ins Grundwaser aktiv eindringen, wie Hydra sp., Lymnaea sp., Sadleriana sp., Erpobdella sp., Coleoptera-L.(Dytiscidae, Helmidae). Oligochaeta (meistens auch Naididae) sind regelmässig zahreich vertreten, ebenso Cyclopoida und Nematoda. Da leben noch Niphargus longidactylus, N. pectinicauda und N.l.ljubljanensis, ihre Besiedlung kann sogar ziemlich dicht sein an solchen Stellen, wo die Oberflächen-Tiere fast verschwinden. Nur an solchen Stellen, wo kleine Grundwasserstrahlen aus dem Ufer ausfliessen, findet man bei der Oberfläche auch Proasellus vulgaris.

In Metertiefe ist die Zusammensetzung der Fauna fast jenen Faunen gleich, die man an einigen Stellen unter dem Flussstrom in der gleichen Tiefe findet und die als insektenarm bezeichnet wurden. Scheinbar vertritt an den Stellen mit bemerkbarem Wasserstrom Proasellus vulgaris den $P$. deminutus des stehenden Wassers. Die Naididae sind hier kaum noch vorhanden, ebenso die Insektenlarven.

An der höheren Uferterrasse waren im Gebiet der Hauptinfiltrationszonen drei Nortonbrunnen vorhanden, die nur je etwa $5 \mathrm{~m}$ vom Wasserrand des Flusses entfernt waren. Während zwei Brunnen beim Pumpen nur wenige Tiere lieferten, fanden wir in den Proben aus dem dritten, am Sava-Ufer bei Dovjeẑ, eine Fauna, die nicht nur individuen- sondern auch sehr artenreich war.

Die Nortonröhren reichen nur etwa metertief in das Grundwasser. Obgleich wir keine exacten Daten über die hydrographischen Verhältnisse haben, zeigen uns die Temperaturverhältnisse, sowie die Faunenzusammensetzung, dass der Einfluss des Flusses hier wieder ein wenig milder ist als bei den obenerwähnten, durch BR-Sonden erreichten Grundwasserstellen. Über den Kontakt mit dem Flusswasser sprechen hier die Temperaturverhältnisse; trotz einer etwa $3 \mathrm{~m}$ dicken Schotterschicht, die diese Stelle bedeckt, ist die Wassertemperatur einer jährlichen Schwankung von $14^{\circ}\left(4^{\circ}\right.$ bis $18^{\circ} \mathrm{C}$ ) unterworfen. Auch das - zwar ausserordentlich seltene - auftreten der ausgesprochen stygonen Cladocera in den Proben spricht für das periodi- 
sche Eindringen des wenig filtrierten Flusswassers in diese Stelle. Trotzdem findet man hier keine Chironomiden-Larven mehr.

Wegen des stetigen Pumpens musste sich in unmittelbarer Umgebung des Nortonbrunnens am Dovjê̂ ein geräumiges System sandloser Lücken in der Schotterschichten ausbilden. Man findet in den Proben auch keine DetritusTeilchen. Aus diesem Brunnen konnte man (1959-1965) im Durchschnitt je etwa 30-300 Exemplare auf 500-1000 l Wasser bekommen. Insgesammt wurden über 30 Tierarten gefunden (Taf. 2), beim jeden Pumpen je etwa 10 (bzw. 6-15) Arten. Mit durchschnittlich etwa 50\% der Exemplare je Probe hat im Jahre 1959 Proasellus deminutus überwogen, ihm folgen die Cyclopoida. Im Jahre 1964 haben beide Gruppen die Priorität ausgetauscht (Abb. 3). Niphargus (mit wenigstens 8 Arten) steht in beiden Fällen der zweitmächtigsten Gruppe wenig nach. In wenigen Exemplaren, aber sehr regelmässig kommen 2 Bogidiella spp. und Oligochaeta vor. Die zuerst in vereinzelten Exemplaren vorkommende Harpacticoida, Ostracoda, Bathynellacea, sind gegen Mitte 1964 fast ausgeblieben. Andere Formen treten mehr vereinzelt und unregelmässig vor (so nur je einmal Alona sp. und Chydorus sp.).

In anderen Nortonbrunnen längs des Sava-Ufers wurden nur vereinzelte

Tab. 2. Struktur der Fauna im Nortonbrunnen am Dovjeẑ (Sava-Ufer N von Ljubljana). Die erste Nummer bezeichnet die Regelmässigkeit des Auftretens ( 1 - bis 3 Proben, 2 - bis $50 \%$ der Proben, 3 - regelmässig oder konstant), die zweite die Häuffigkeit in einzelner Probe (1 - 1-2 Exemplare, 2 - 1-10 Exemplare, 3 - zahlreich). Es wurden etwa 10001 Wasser pro Probe gefiltert.

TURBELLARIA
Tricladida g.sp.
Turbellaria g.sp.A
Turbellaria g.sp.B
NEMATODES
Nematodes gg.spp.
GASTROPODA
Hadziella deminuta Bole
Hauffenia cf. michleri Kuŝcer
Mervicia eximia Bole
OLIGOCHAETA
Rhynchelmis sp.
Trichodrilus pragensis (Vejdovsky)
Oligochaeta gg.spp.
CYCLOPOIDA
Acanthoc. venustus (Norm. et Scott)
A. kieferi (Chappuis)
A.hispanicus Kiefer
Diac.languidoides (Lilljeb.)
Megac. viridis (Jurine)
HARPACTICOIDA
Nitocrella slovenica Petk.
Nitocrella hirta Chappuis

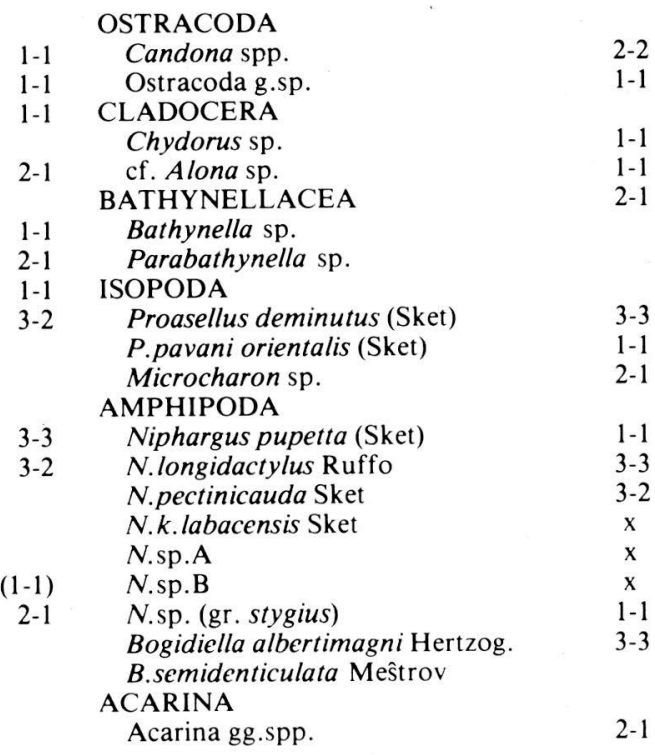


Exemplare der Niphargus-, Proasellus-, Bogidiella- und Cyclopoida-Arten ausgepumpt.

Im Inneren des Ljubljansko polje haben wir das Wassers, das aus den frischen, erst gereinigten, für die neue Wasserwerkstation gemachten Bohrungen gepumpt wurde, filtriert. Diese Bohrungen liefern uns das Wasser aus allen Schichten, vom Wasserspiegel (etwa $10 \mathrm{~m}$ unter der Feld-Oberfläche) bis zur Tiefe von $50 \mathrm{~m}$, gemischt. Die Temperatur beträgt $11 \pm 1^{\circ} \mathrm{C}$. Von der nächsten Stelle des Sava-Ufers sind diese Bohrungen etwa $2,5 \mathrm{~km}$ entfernt; das bedeutet, dass das hier gepumpte Wasser wenigstens (!) 100 Tage durch die filtrierenden Schotterschichten fliesst. Nach allen Eigenschaften zu urteilen (chemischen, bakteriologischen, organoleptischen) ist dies ein ausserordentlich gutes Trinkwasser. Die unten angeführten Daten über die Fauna gelten für das Versuchpumpen, beim welchen wir aus 4 Bohrungen insgesammt 5.000.000 1 Wasser filtriert haben. Zwei Jahre nach dem Beginn des regelmässigen Gebrauchs des Pumpwerkes konnte man in 380.0001 Wasser kein Tier finden. In der erwähnten Wassermenge fanden wir nur etwa 720 Exemplare des Niphargus longidactylus, je 30 Exemplare des N.jovanovici multipennatus und der Oligochaeta, je 10 bis 1 Ex. von Niphargus pectinicauda, Niphargus sp. indet., N.serbicus und Proasellus pavani orientalis. Die Copepoda könnten in einer kleiner Zahl vorhanden sein (mit der gebrauchten Methode nicht feststellbar), jedenfalls aber nicht zahlreich. Bezeichnend ist das vollkommene Abwesenheit des Proasellus deminutus. Erwähnenswert ist das allmähliche Verkleinern der Tierzahl während des Pumpens.

Auch die Fauna in (zwar schon sehr seltenen) Nortonbrunnen im Inneren der Ebene, die uns nur das Grundwasser der obersten Schichten liefern, ist äusserst individuen- und artenarm. Ihre Zusammensetzung ist zwar jener der Tiefbohrungen ähnlich, nur Niphargus longidactylus hier nur ausnahmsweise, Proasellus deminutus aber ziemlich regelmässig auftritt.

1959
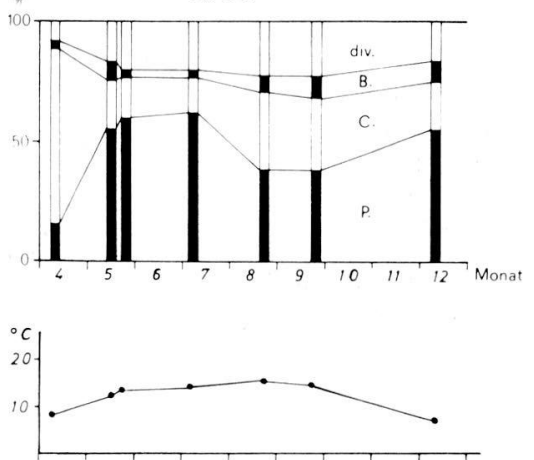

$1964 / 65$
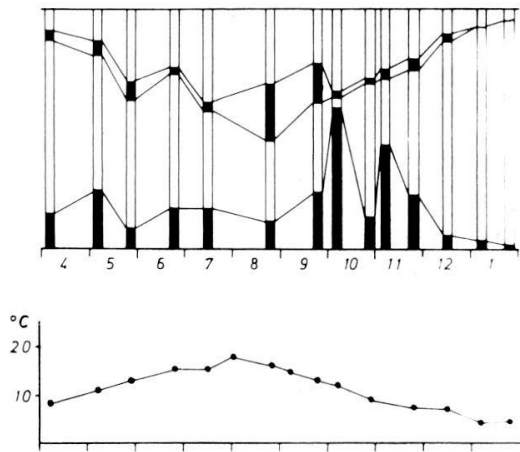

Abb. 3. Struktur der Fauna im Nortonbrunnen am Dovjê̌ während der Jahre 1959 und 1964; unten die Kurven der Wassertemperatur; P - Proasellus deminutus, C - Cyclopoida, B - Bogidiella spp., div. - andere Tierarten. 
Ein besonderes, fremdartiges Habitat in diesem Gebiete stellen die ausgegrabenen Schachtbrunnen vor. Es handelt sich hier nähmlich um grössere, mit Wasser ausgefüllte Räume, die für ausgesprochen tygmotaktische Tiere ungünstig, für die Tiere mit grösseren Körperausmassen aber äusserst günstig sein können. Die Temperaturschwankungen des Wassers können gegenüber dem "normalen" Grundwasser der Ebene nur leicht vergrössert sein. Eine äusserst günstige Erscheinung, welche die Entwicklung dichteren Tierpopulationen ermöglicht, ist das stettige Vorhandensein einer futterreichen Detritusschicht am Boden der Schachtbrunnen. Solche Brunnen sind im Gebiet fast nicht mehr vorhanden, denn die alten sind wegen des erniedrigten Grundwasserstandes trocken geworden. In den Brunnen waren sonst regelmässig Oligochaeta, Cyclopoida, manchmal Diptera-Larven vorhanden, ausserdem gewöhnlich ziemlich dichte Population einer Niphargus-Art. In einem Fall war dies der winzige N.longidactylus, in einigen anderen der grosse Niphargus "longicaudatus" ljubljanensis. Man muss bemerken, dass ausserhalb des oberen Teiles des Sava-Systems solche Brunnen sehr oft und dicht Proasellus slavus sspp. besiedeln. Von den Quellen am Ost-Ende des Ljubljansko polje haben wir eine kleine Rheocrene untersucht, die aus leicht verkarsteten Konglomeraten durch eine Schotteransammlung fliesst. Während in der Quelle selbst schon epigäische Tiere wie Gammarus fossarum Koch, Belgrandiella fontinalis und B.kuesteri massenhaft vorkommen, aber auch für die Kluftgewässern des Karstes charakteristische Niphargus stygius und Hauffenia erythropomatia (Hauffen) vorhanden sind, lieferte uns eine unmittelbar oberhalb des Ausflusses eingehammerte BR-Sonde auch typische Bewohner des Interstizialwassers. Beide Belgrandiella-Arten, die im Ufergrundwasser des SavaFlusses äusserst selten vorkommen, sind hier ziemlich dicht besiedelt. Niphargus longidactylus, N.pupetta, N.serbicus, N.j.multipennatus kommen in wenigen Exemplaren vor, ebenso aber auch Proasellus vulgaris und Hauffenia cf. erythropomatia. Charakteristisch ist das Fehlen der Cyclopoida.

\section{ÖKOLOGISCHE UND ZOOGEOGRAPHISCHE CHARAKTERISIERUNG EINIGER FAUNENELEMENTE}

Bythinella schmidti tritt im behandelten Gebiete regelmässig im Grundwasser an solchen Stellen auf, wo auch die Insecten-Larven noch vorhanden sind. Sie ist also auf die Einflusszone des Flusswassers gebunden, obgleich sie im Benthos des Flusses nicht vorkommt. Alle Exemplare sind (die Augen ausgenommen) weitgehend depigmentiert. Sonst ist diese Schneckenart in Slovenien weit verbreitet (Sava-System, Karstgebiete eingeschlossen; Radoman 1976). Sie lebt in Quellen und Bächen, so auf kalkigen als auch auf SilikatUnterlage und wurde oft in Höhlengewässern und in ausgegrabenen Brunnen gefunden.

Belgrandiella fontinalis und B.kuesteri treten im Grundwasser längs des Flusses nur vereinzelt und im Inneren des Ljubljansko polje überhaupt nicht vor, massenhaft aber in den Ausflussquellen. Beide Arten sind in Slovenien (ausser des NO) weit verbreitet (Radoman 1975), der obengenannten Bythi- 
nella ökologisch ähnlich; auch sie zeigen eine ausgesprochene Neigung zum eindringen in die unterirdische fliessende Karstgewässer.

Hadziella deminuta findet man vereinzelt im Grundwasser des SavaSystemes in Slovenien. Dieselbe (oder sehr ähnliche) Form tritt auch in den kleinen Karstquellen desselben Gebietes auf. Diese Form ist von der Arten des Dinarischen Karstes morphologisch ziemlich weit entfernt.

Proasellus deminutus scheint eine ziemlich hoch spezialisierte interstiziellform zu sein. Sie wurde fast nie im futterreichem Potamostygon in Gesellschaft mit den epigäischen Tieren gefunden, überhaupt nie in den ausgegrabenen Brunnen oder in den Karstgewässern. Trotzdem bildet diese Form dichtere Populationen nur stellenweise, in der Nähe der Flüsse, wo sie auch grösseren Temperaturschwankungen unterworfen sein kann. Diesem anscheinenden Hapthabitat entsprechend hat P.deminutus eine ausgesprochene Reproductions-Periodizität. Die Zahl der $\odot$ mit Oostegiten ist im Mai, die Zahl der freien Jungen im Juli am höchsten. Vom September bis März findet man im Nortonbrunnen am Dovjeẑ nur vereinzelte, ausgewachsene, reproductionsunaktive Tiere (Sket 1965).

Proasellus vulgaris vulgaris (früher als Asellus deminutus vulgaris beschrieben) ist der obenerwähnten Form ohne Zweifel sehr nahe verwandt. Er wurde zuerst in den Höhlengewässern am Rande des Dinarischen Karstes und in inselartigen Karstmassiven gefunden, später aber auch in interstiziellen Gewässern der weiteren Umgebung des Ljubljansko polje, doch immer in fliessenden unterirdischen Wasserstrahlen (in "Schotterquellen"). Er scheint dem $P$.deminutus gleiche Reproductionsperiodizität zu haben.

Die ganze deminutus-Gruppe stellen sehr kleine (unter $5 \mathrm{~mm}$ lange) und ziemlich schlanke Tiere vor, deren Besonderheit ein sehr stark erweiterter Endit des I.Maxillen-Basale ist. Diese Erscheinung könnte der erweiterten Maxille des Niphargopsis analog sein und vielleicht dieselbe Rolle bei der Ernährung mit feinen Partikeln spielen. Alle morphologische Eigenschaften zeigen uns, sich diese Gruppe in interstiziellen Gewässern entwickelt und erst später teilweise in die Höhlenhabitate eingedrungen ist. Das bekannte Areal der Gruppe umfasst die nordwestlichsten Teile des Dinarischen Karstes und die Schotteransammlungen längs der grösseren Flüsse in NW-Jugoslavien und NO-Italien (Sket 1965, unveröffentl. Daten). Mit dieser Gruppe sind P.pavani Arcangeli und P.beroni Henry et Magniez aus Slovenien, NO-Italien und Korsika verwandt, die auch ökologisch wenig spezialisierte unterirdische Formen zu sein scheinen.

Niphargus longidactylus ist vielleicht die am weitesten verbreitete Tierform des Interstizielwassers so im Ljubljansko polje als auch in Slovenien überhaupt (Abb. 4). Er kommt ebenso in den Flussnahen wie auch in den flussfernen Grundgewässern vor, scheint aber das Potamostygon nur spärlich zu besiedeln. N.longidactylus scheint grössere Interstizien vorzuziehen und .bildet manchmal auch in ausgegrabenen Schachtbrunnen sehr reiche Populationen; trotzdem wurde diese Art in Jugoslavien nie in einem Karstwasser gefunden. N.longidactylus scheint in bevorzugtem Habitat äusserst konkurrenzfähig zu sein, seine Abbundanz ist oft sehr hoch.

N.longidactylus wurde bisher in NO-Italien (Verona) sowie in 
N-Slovenien, W-Kroatien und Bosnien gefunden, an einigen Stellen in nächster Nähe des Karstes, doch immer ausserhalb desselben. Andere Arten seiner Gruppe, (transitivus-Gruppe nach Sket 1971), die innerhalb der Gattung morphologisch ziemlich abweichend ist, leben im Gebiet des Dinarischen Karstes, auch nördlich davon und in Rumänien, selten auch in Höhlenseen.

Der derselben Gruppe angehörende aber grössere N.pectinicauda scheint für den Oberlauf des Sava-Flusses endemisch zu sein, wo er regelmässig, aber immer in einer weit kleineren Zahl den N.longidactylus begleitet. N.pupetta ist dagegen im Grundwasser zwischen NO-Italien und W-Rumänien weit verbreitet, wurde aber im Ljubljansko polje nur in insektenlosem Grundwasser gefunden, ausserdem nie in unterirdischen Karstgewässern des Dinarischen Karstes.

Niphargus jovanovici multipennatus scheint an das Interstizialwasser gebunden zu sein, zeigt aber hiefür keine Spezialisierung (Sket 1972). Er kommt in den Grundgewässern der feineren wie auch der grosskörnigeren Substraten, so im Potamostygon, wie auch in Eustygon vor. Nach unseren Erfahrun-

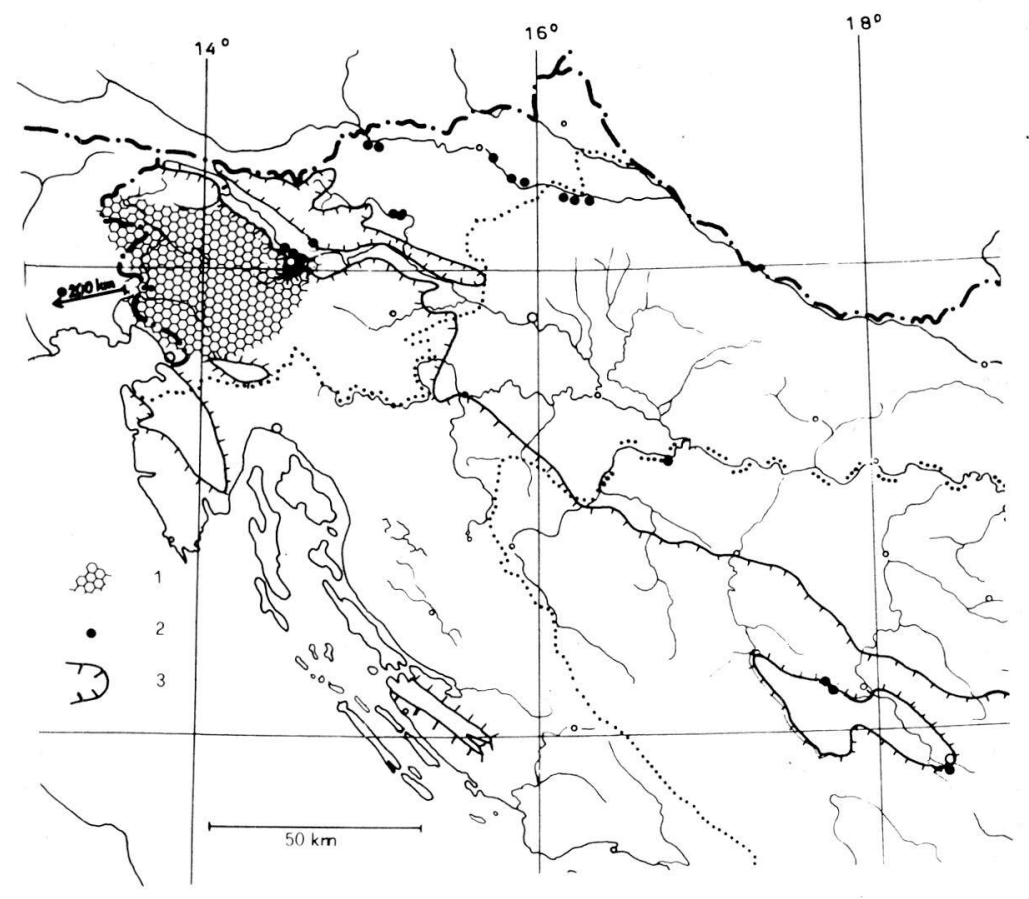

Abb. 4. Verbreitung des Niphargus stygius (Schioedte) und Niphargus longidactylus Ruffo; die letzterwähnte Art wurde auch bei Verona gefunden und ist wahrscheinlich in Friuli weiter verbreitet; 1 - N.stygius, 2 - N.longidactylus, 3 - Grenzen der grösseren Karstmassive (nur in Grenzen Jugoslaviens eingezeichnet). 
gen sind jedoch seine Populationen immer äusserst schütter, in keinem Habitat haben wir eine dichtere Besiedlung feststellen können. Nur ausnahmsweise wurde er in Schachtbrunnen gefunden, nie aber in Höhlengewässern.

Diese Form ist in den Schotterablagerungen längs der Sava wenigstens von NW-Slovenien bis Zagreb verbreitet, scheint aber auch in Bosnien vorzukommen.

Niphargus serbicus ist in faunareichem Grundwasser des Ljubljansko polje eine äusserst seltene Erscheinung. Es handelt sich wahrscheinlich um eine äusserst konkurrenzschwache Tierart, die nur an solchen Orten lebt, wo fast keine andere Tiere workommen. Im Potamostygon wurde sie nie gefunden. N.serbicus scheint grössere Interstizien zu bevorzugen und lebt auch in den Schachtbrunnen, nie aber in Höhlengewässern. Fast ausnahmslos wurden nur vereinzelte Exemplare gefunden.

Die Niphargus-jovanovici-Gruppe, zu welcher beide vorgenannten Formen gehören, ist in Europa weit verbreitet, alle Formen sind an das Interstiziallwasser gefunden. Nur zwei davon kommen ausnahmsweise auch in unterirdischen Gewässern des Karstrandes vor. Keine wurde bisher im Inneren des Dinarischen Karstes gefunden.

Niphargus "longicaudatus" ljubljanensis Vodnik (unveröffentlicht) ist die grösste unterirdische Tierart des Ljubljansko polje. Er kommt vor allem in Schachtbrunnen vor, wo er ziemlich dichte Populationen bilden kann. Man findet aber vereinzelte Tiere auch im Potamostygopsephal und auch im Eustygon, was seine Fähigkeit, sich durch die Interstizien auszubreiten, dokumentiert. Doch wurden an solchen Stellen immer nur junge Tiere gefunden. In den Brunnen, wo diese Form in reicheren Populationen gefunden wurde, variierte die Temperatur während des Jahres um einige Grade (in Brunnen in Savlje 9,5-12,9 ${ }^{\circ}$ ). Die Bruttragenden $q$ wurden nur in der Zeit vom Juli bis Dezember gefunden (Vodnik, unveröff.).

Diese Form wurde bisher mit Sicherheit nur in den obenerwähnten Habitaten längs eines kürzeren Sava-Abschnittes gefunden, doch ist ihr Vorkommen in den umgebenden Karstgewässern nicht ausgeschlossen (hierzu wäre eine Revision des Materiales nötig). Diese Niphargus-Form ist jenen sehr nahe verwandt, die Karaman (1952) als Unterarten des N.stygius aus NOSlovenien und W-Kroatien beschrieben hat. Sie leben in Schachtbrunnen sowie in unterirdischen Karstgewässern aller Typen. Allerdings gehören alle diese Taxa in die weitere Gruppe stygius-puteanus, die einige sehr euryöke Formen enthält. Ihr Areal bedeckt grosse verkarstete und unverkarstete Teile Europas. Niphargus stygius (Schioedte) wurde längs der Sava nur an zwei Stellen im Schotter gefunden, immer beim Ausfluss des Grundwassers, mit Proasellus vulgaris zusammen. N.stygius bzw.seine Forma valvasori lebt in Karstgewässern W-Sloveniens. bei den oben erwähnten Populationen konnten wir als einzigen Unterschied gegenüber valvasori nur eine kleinere Körperlänge feststellen.

Die Bogidiella spp., Microcharon sp. (cf. acherontis) und Bathynellacea wurden in Dinarischem Karste nur ausnahmsweise in Höhlengewässern gefunden, innerhalb des interstiziellen Lebensraumes zeigen sie aber keine zu grosse Spezialisierung. 


\section{SCHLÜSȘE}

Der Grundwasserkörper des Ljubljansko polje (NW-Jugoslavien) bekommt sein Wasser hauptsächlich aus dem Flussbett des Sava-Flusses, an einigen Stellen sind aber offensichtlich auch Verbindungen mit Karstgewässern vorhanden. Als Hauptinfiltrationszone kommt der Bettboden im Strom und nicht das mit organischen Abfällen verstopfte Ufer in Betracht. Die Hauptmasse des Grundwassers bewegt sich mit einer Geschwindigkeit von 10 $\mathrm{m} / \mathrm{Tag}$, doch bilden sich stellenweise kleine Wasserstrahlen mit ansehnlicheren Geschwindigkeiten.

In der unmittelbarer Nähe des Flusses sind die Jährlichen Temperaturschwankungen beträchtlich, in der Mitte des Ljubljansko polje erreichen sie kaum ein Paar Grad. Die $0_{2}$-Sättigung des Grundwassers erniedrigt sich schon etwa $1 \mathrm{~m}$ von gesättigtem Flusswasser entfernt, auf etwa 40-60\%.

Obgleich die Interstizien in Schotterschichten teilweise von feineren Sedimenten verstopft sind, sind hier ausgesprochen stygopsammale Tierformen nur mit vereinzelten Exemplaren und Arten vertreten. Bemerkbar ist auch die Armut an Nematoden un das fast vollkommene Abwesenheit der Acarina (vergleiche Danielopol 1976).

Bewohner des Fluss-Benthos (Chironomidae, Tipulidae, Leuctra spp., Baetis spp.) dringen in das untersuchte Grundwasser nur in wenigen Exemplaren ein (vergleiche Ruffo 1961, Danielopol 1976), nur die Naididae sind da zahlreicher vertreten. Trotzdem findet man im Grundwasser der nur periodisch überfluteten Schotterbänke auch dem Grundwasser vollkommen fremde Tiere, was eine indirekte Folge der Wasserstand-Oszillationen sein muss. Ziemlich regelmässig sind im flussnahen Grundwasser epigäische (creno- und troglophile) Tiere vorhanden, die im Fluss selbst überhaupt nicht gefunden wurden.

Als Faktoren, welche die Verteilung einzelner Arten innerhalb des untersuchten Grundwasserkörpers bedingen, kommt vor allem die Anwesenheit der Futteransammlungen und die damit bedingte Kompetition unter den Arten, weiter die Wasserströmung und einige schwieriger definierbare Faktoren in Betracht. Die Substratbeschaffenheit, Durchlüftung und andere Wassereigenschaften scheinen in diesem Falle keinen zu grossen Einfluss auf die Fauna zu haben.

Während mehrere Tierarten die futterreiche Nähe des Flusses ziemlich dicht besiedeln, trifft man im Inneren des Ljubljansko polje auf eine Armut an Arten- als auch Individuenzahlen. Dafür findet man aber hier einige Arten, die in der futter- (und konkurrenz-) reichen Zone nicht oder kaum vorhanden sind, ziemlich regelmässig. Die Wasserbewegung scheint die Ansiedlung einiger Formen (Cyclopoida, Proasellus deminutus) zu verhindern, andere Formen (P.vulgaris) sind dagegen an die Wasserströmung gebunden.

Einige Arten sind im Rahmen des Stygopsephals äusserst euryök ( $\mathrm{Ni}$ phargus longidactylus), andere dagegen sehr spezialisiert. Einige bilden sehr dichte Populationen und sind auch in energetisch ungünstigen Verhältnissen noch ziemlich dicht besiedelt, einige vermögen nur in günstigsten Bedingun- 
gen dichte Populationen zu bilden und einige scheinen überhaupt eine niedrige Abundanz zu haben.

Zoogeographisch betrachtet ist die behandelte Fauna aus recht verschiedenen Elementen zusammengesetzt. Es gibt hier die Tiere, die in Europa weit verbreitet sind und von Mitteleuropa bis zur Grenzen des Dinarischen Karstes(Bogidiella albertimagni) oder sogar ins Karst selbst (Trichodrilus pragensis, Acanthocyclops kieferi) eindringen. Auf die unterirdischen Gewässer des Oberlaufes des Sava-Flusses selbst scheinen Bogidiella semidenticulata, $\mathrm{Ni}$ phargus pectinicauda und Hadziella deminuta beschränkt zu sein. In allen Fällen handelt es sich um die Tiere, deren Haupthabitat die interstiziellen Gewässer sind un nur sporadisch in den unterirdischen Karstgewässern auftreten.

Niphargus stygius ist hier die enzige Tierform, die bestimmt aus der Karstgewässern stammt, und er ist im Grundwasser des Feldes auf ein ganz eigenartiges Habitat beschränkt. Es scheint, dass sich die ganze Proasellus deminutus-Gruppe am Kontakt des Karstes mit den Interstizielgewässern grosser Ebenen entwickelt hat, und dass einige Formen eher aus der Interstiziellgewässern in das Karst eingedrungen sind, als umgekehrt. Dagegen scheint (nach der Verbreitung der Gruppen beurteilend) für die Gattungen Hauffenia und Hadziella das Karst das Ursprungsgebiet zu sein. Eine so scharfe Abgrenzung der Höhlenfauna von der phreatischen in diesem Gebiet ist recht merkwürdig. Beide Faunen leben hier in einem grossen Reichtum in einem räumlich engem Kontakt. Es steht dem Gedanken nahe, dass gerade durch die Vielfältigkeit der beiden Faunen verursachte hohe Kompetition (und Spezialisierung) eine Mischung der Arten verhindert.

\section{LITTERATUR}

BARTHELEMY, C. 1968. Contribution a la connaissance des Leuctridae. Ann. Limnol. 4(27):175-198.

BOLE, J., 1967. Polẑi iz freatiĉnih voda Jugoslavije. Razprave SAZU, Cl. IV, 10(3):111-120.

BOU, C. 1968. Faune souterraine du sud-ouest du Massif Central, II.- Contribution a la connaissance de la faune des eaux souterraines de l'Albigeois. Ann.Speleol. 23(2):441-473.

BREZNIK, M. 1969. Podtalnica Ljubljanskega polja in moẑnosti njenega poveçanega izkoriŝcanja. Geologija (Ljubljana) 12:165-184, 2 Beilagen.

DANIELOPOL, D. 1976. The distribution of the fauna in the interstitial habitats of riverine sediments of Danube and Peisting. Int.J.Speleol. 8:23-51.

HUSMANN, S. 1966. Versuch einer ökologischer Gliederung des interstitiellen Grundwassers in Lebensbereiche eigener Prägung. Arch.Hydrobiol. 62(2):231-268.

HUSMANN, S. 1972. Das ökologische Gleichgewicht im Grundwasser sandig-kiesiger Ablagerungen usw., Tagungsber.Gesellschaft f.Ökol., Giessen 89-96.

HUSMANN, S. 1975. Versuche zur Erfassung der vertikalen Verteilung von Organismen und chemischen Zubstanzen im Grundwasser von Talauen und Terrassen; Methoden und erste Befunde. Int.J.Speleol. 6:271-302.

ILLIES, J., and L. BOTOSANEANU 1963. Problemes et methodes de la classification et de la zonation ecologique des eaux courantes, consideres surtout du point de vue faunistique. Mitt.Int.Ver.Limnol. 12:1-57.

KARAMAN, S. 1952. Podrod Stygoniphargus u Sloveniji i Hrvatskoj, Prirodoslovna istraz̃ivanja JAZU, Zagreb 25:5-38. 
LATTINGER-PENKO, R. 1976. Quelques donnees sur la population de Proasellus slavus ssp.n. Sket (Crustacea, Isopoda) dans l'hyporheique de la riviere Drave pres de Legrad. Int.J.Speleol. 8:107-115.

MATONIĈKIN, et al. 1975. Prilog valorizaciji voda ekosistema rijeke Save, Zagreb $96 \mathrm{pp}$.

MEŜTROV, M. 1960. Faunisticko-ekoloŝka i biocenoloŝka istraẑivanja podzemnih voda Savske nizine. Biol.Glasnik 13:73-109.

MESTROV, M. 1961. Über neue Bogidiella-Arten (Crustacea, Amphipoda) aus unterirdischen Gewässern Kroatiens und Sloweniens. Zool.Anz. 167(1/2):74-80.

MOTAS C. 1962. Procede des sondages phreatiques - division du domaine souterrain - classification ecologique des animaux souterrains - le psammon. Acta.Mus.Macedonici Sc.Nat. 8(7):135-173.

RADOMAN, P. 1975. Specijacija u okviru roda Belgrandiella i njemu srodnih rodova na Balkanskom poluostrvu. Glasnik Prir.Muz. (Beograd), Ser.B., 30:29-69.

RADOMAN, P. 1976. Speciation within the family Bythinellidae on the Balkans and Asia Minor. Z.f.zool.Systematik u.Evolutionsforschung 14(2):130-152.

RUFFO, S. 1961. Problemi relativi allo studio della fauna interstiziale iporreica. Boll.Zool. 28(2):273-319.

SKET, B. 1965. Subterrane Asellus-Arten Jugoslaviens (Crustacea, Isopoda). Acta Mus.Macedonici Sc.Nat. 10(1):1-26, 14 Beil.

SKET, B. 1971. Vier neue aberrante Niphargus-Arten (Amphipoda, Gammaridae) und einige Bemerkungen zur Taxonomie der Niphargus-ähnlichen Gruppen. Razprave SAZU, Cl.IV 16:1-25, 1 Beil.

SKET, B. 1972. Die Niphargus jovanovici-Gruppe (Amphipoda, Gammaridae) in Jugoslawien und NO-Italien, taxonomisch, zoogeographisch und phylogenetisch betrachtet, Razprave SAZU, Cl.IV 15:98-141, 2 Beil.

SKET B. et F. VELKOVRH, 1981. Postojna-Planina-Cave system as a model for the investigations of the polluted subterranean rivers, Naŝe jame 22 (in press).

STANFORD, J.A., and A.R. GAUFIN 1974. Hyporheic communities of two Montana rivers. Science 185:700-702.

VODNIK, F. (unveröffentlicht). Prispevek k poznavanju nifargov iz talne vode na Posavju pri Ljubljani, manuscr. 5 pp.

ŻLEBNIK, L. 1971. Pleistocen Kranjskega, Sorŝkega in Ljubljanskega polja. Geologija (Ljubljana) 14:5-51, 4 Beilagen. 



\title{
The Edwards Aquifer: Earth's Most Diverse Groundwater Ecosystem?
}

\author{
Glenn Longley*
}

\author{
SUMMARY
}

Recent studies on the Edwards Aquifer, a karstic formed cavernous system in Texas, indicate an extremely diverse community of aquatic troglobites. Sampling of wells and springs is providing new insight into the dynamics of this fascinating system, which is possibly the most diverse subterranean aquatic ecosystem known in the world today.

The Edwards Aquifer is found in association with the Balcones Escarpment in central Texas. The Balcones Escarpment and Fault Zone is the dominant structural feature in the area, and the major faults occur as a series of closely spaced step faults that trend eastward in Kinney County to Bexar County area then northeastward from Bexar County to Hays County. The Edwards Aquifer is a porous, honeycombed, cavernous limestone that consists of fine grained carbonate rocks between the base of the Del Rio Clay and the top of the Glen Rose Formation. The thickness of the porous beds of Edwards limestone varies between 122 and $152 \mathrm{~m}$ (Puente, 1976). The aquifer is about 282 $\mathrm{km}$ long, from 8 to $64 \mathrm{~km}$ wide, and has two major features: the recharge area and the artesian area (Fig. 1). The water entering the aquifer moves first southward from the Edwards Plateau then eastward and northeastward toward large natural outlets at Comal Springs in New Braunfels and San Marcos Springs in San Marcos. Other discharges from the aquifer are Leona Springs in Uvalde, San Antonio and San Pedro Springs in San Antonio, and Hueco Springs north of New Braunfels. An illustration of the possible structure of the cavernous Edwards is given in Figure 2. This indicates the possible relationship between flow and the top of the piezometric surface (Arnow, 1959). Many wells have been drilled into the artesian part of the aquifer, and many of them in the San Antonio area flow at ground level. The fauna occurring in the aquifer, springs, and flowing artesian wells were sampled during the studies. In a few instances, pumped wells were sampled.

Recharge averages more than $616 \mathrm{hm}^{3}$ (cubic hectometers). The total amount of water stored in the aquifer is not known. During the period 1934

* Director, Edwards Aquifer Research / Data Center. Aquatic Station (Biology Department) Southwest Texas State University San Marcos, Texas 78666. 


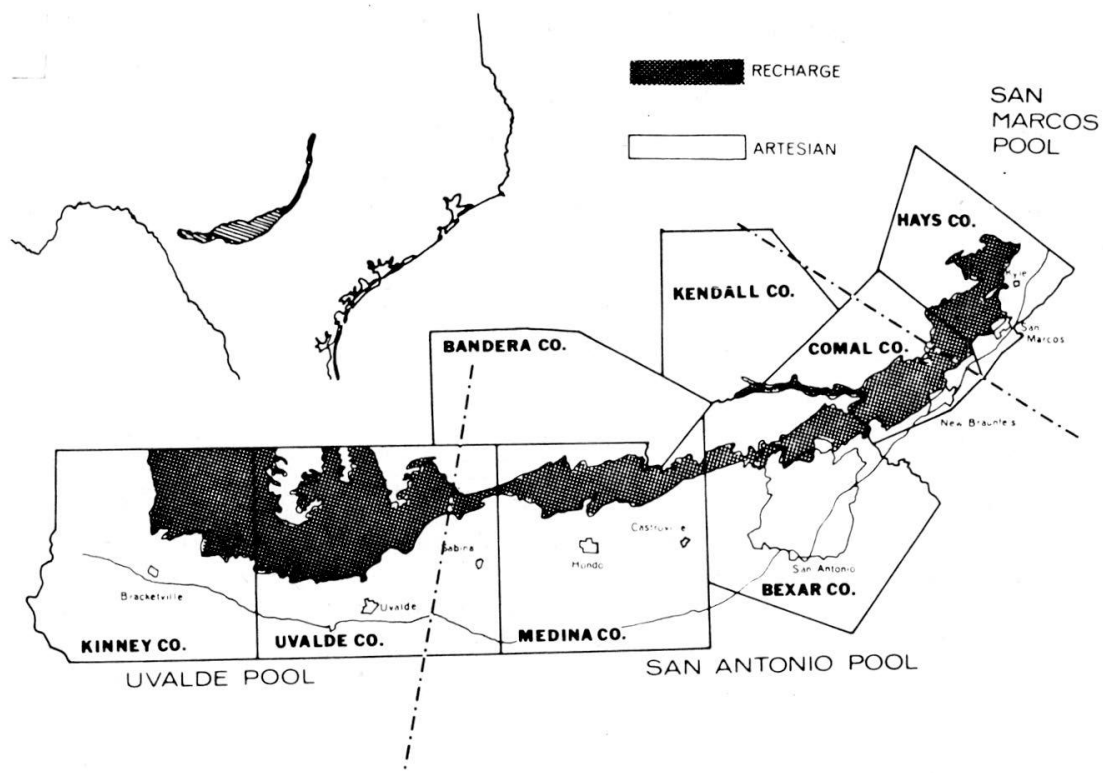

Fig. 1. Edwards Aquifer.

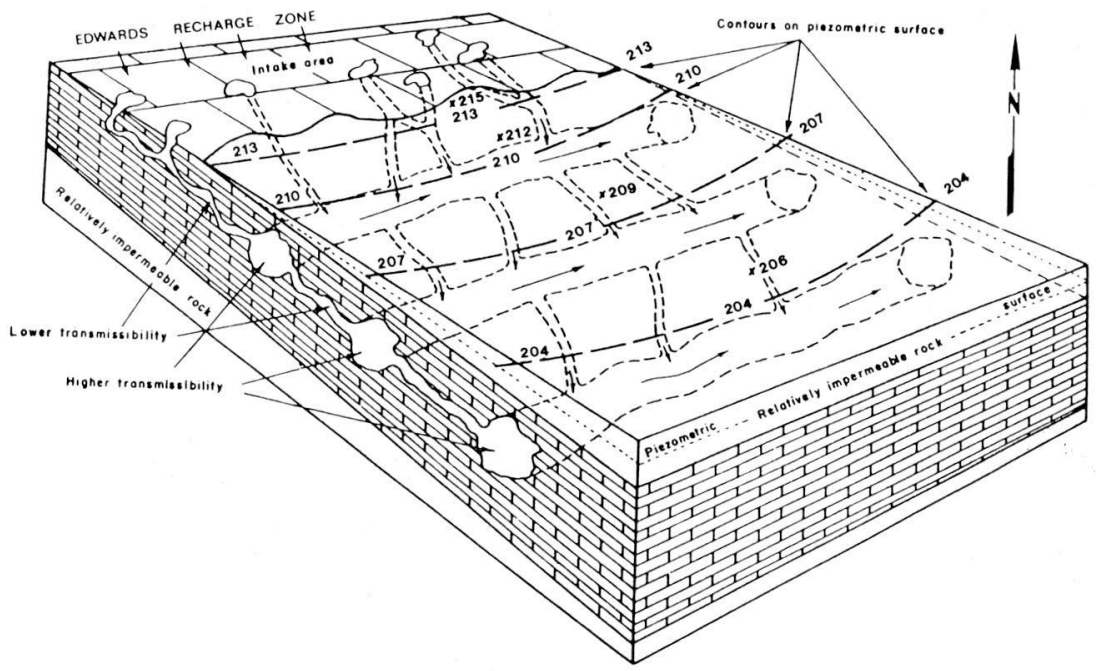

Fig. 2. Hypothetical diagram of flow in the Edward Aquifer. 
to 1975 , a minimum recharge of $54.25 \mathrm{hm}^{3}$ occurred in 1956 and a maximum recharge of $2,096 \mathrm{hm}^{3}$ occurred in 1958 . In $1971,501.58 \mathrm{hm}^{3}$ were pumped from the aquifer, the highest amount on record (Edwards Underground Water District, 1977). Estimates of water use in the future, due to increased population pressure, indicate that discharge by pumping will exceed recharge and all of the springs will eventually dry (U.S. Department of the Interior, 1973).

The aquifer is divided into three areas hydrologically: the Uvalde Pool, San Antonio (or Central) Pool, and San Marcos Pool. These areas are connected during times when the piezometric levels are high. During periods of severe drought, it can be expected that water in these areas will be separated by some distance. There is some biological evidence that these high points at the base of the aquifer may be factors limiting the distribution of organisms. An example may be the presence of two species of highly adapted cave salamanders Typhlomolge rathbuni and Typhlomolge robusta, in the San Marcos Pool, (Longley, 1978) and their absence in the San Antonio Pool. Two species of blind catfishes, Satan eurystomus (Longley and Karnei, 1978a) and Trogloglanis pattersoni (Longley and Karnei, 1978b), are the top of the food chain in the San Antonio pool. All four of these vertebrates occur in the artesian region of the aquifer.

Other aquatic vertebrates that occur in caves of the recharge zone of the aquifer are species of the salamander genus Eurycea. These include Eurycea tridentifera (Honey Creek Cave Salamander), Eurycea troglodytes (Valdina Farms Sinkhole Salamander) now thought to be a hybrid swarm between $E$. neotenes and E. tridentifera (Sweet, 1978), Eurycea latitans (Cascade Cavern Salamander), and Eurycea neotenes (an occasional inhabitant of caves from which springs flow.

The Edwards Aquifer has a wide variety of aquatic invertebrates. The troglobitic species are listed in Table 1 . In addition to those mentioned in Table 1 , there are several other species which are certainly troglophilic and may be considered troglobitic by some.

In the San Marcos area, the aquifer is very narrow and the recharge zone is near the entire artesian area. It is easy to visualize local recharge of organic matter as the primary source of energy into the subterranean aquatic system. Numerous caves occur in the recharge zone, near or in stream channels, and they probably account for large amounts of allochthonous debris. In the San Antonio area the aquifer is very wide, and some of the wells yielding aquatic troglobites in southern Bexar County are $32 \mathrm{~km}$ from the nearest known recharge area. These same wells are very near (often less than $1.5 \mathrm{~km}$ ) to the "bad water zone." The wells in the "bad water zone" have high total solids, sulfur compounds, high temperatures, and are also anaerobic. The Edwards formation dips downward to the south. Down dip from the deep wells in Bedar County oil occurs in the Edwards formation. The wells sampled in southern Bexar County were as much as $609 \mathrm{~m}$ deep. These same wells are known to produce small amounts of oil. The amount of oil produced seems to increase when the artesian pressure in the aquifer lowers. The blind catfish are found in these wells along with a varied invertebrate fauna. It is unlikely, 
Table 1. Troglobitic aquatic invertebrate fauna of the Edwards Aquifer.

\begin{tabular}{ll}
\hline \multicolumn{1}{c}{ TAXA } & \multicolumn{1}{c}{ LOCATION } \\
\hline $\begin{array}{l}\text { Phylum Platyhelminthes } \\
\text { Sphalloplana mohri }\end{array}$ & Hays Co., Medina Co. \\
Phylum Mollusca & \\
Horatia (Hauffenia) micra & Hays Co., Comal Co. \\
Species A (snail) & Hays Co. \\
Species B (snail) & Bexar Co. \\
Species C (snail) & Bexar Co. \\
Phylum Annelida & \\
Species A (Hirudinea) & Hays Co. \\
Phylum Arthropoda & \\
Candona sp. (ostracod) & Medina Co. \\
Species A (ostracod) & Hays Co. \\
Cyclops spp. (copepods) & Hays Co., Bexar Co., Uvalde Co. \\
Lirceolus smithii (isopod) & Hays Co., Uvalde Co. \\
Cirolanides texensis (isopod) & Hays Co., Bexar Co., \\
& Uvalde Co., Comal Co. \\
Cirolanidae (undescribed) (isopod) & Bexar Co., Uvalde Co. \\
Stenasellidae (undescribed) (isopod) & Bexar Co. \\
Monodella texana (Thermosbaenacea) & Hays Co., Bexar Co., Uvalde Co. \\
Stygobromus flagellatus (amphipod) & Hays Co., Bexar Co., Uvalde Co. \\
Stygobromus russelli (amphipod) & Hays Co., Comal Co. \\
Stygobromus pecki (amphipod) & Comal Co. \\
Seborgia sp. (amphipod) & Hays Co. \\
Plus 8 other amphipod species (I new & Hays Co., Bexar Co., \\
family, 4 new genera)* & Comal Co. \\
Palaemonetes antrorum (shrimp) & Hays Co., Bexar Co. \\
Palaemonetes holthuisi & Hays Co. \\
Haideoporus texanus (beetle) & Hays Co. \\
\hline & \\
\hline &
\end{tabular}

* See Holsinger and Longley 1980.

due to distance and hydrology, that organic matter washed into the aquifer in the recharge zone is reaching these deep wells. It should be noted that in the strata above the aquifer in this area there are deposits of oil and peat. Oil is being pumped in this area.

I propose a hypothesis regarding the energy input into the aquatic ecosystem in this part of the aquifer. I contend that the organic matter down dip in the Edwards is continuously migrating up the strata until it contacts the "good Edwards" water. The samples from wells contain large amounts of material that mycologists have described as mycelia from fungi. My concept of the food chain in this system is that saprophytic fungi grow on the fossil organic matter or on bacteria that utilize the organic matter. The fungi serve as food for the smallest invertebrates in the system which are then fed on by the larger invertebrates. The larger invertebrates including amphipods, isopods, decapods (shrimps), and snails are then fed upon by the blind catfishes in the San Antonio area. The toothless blindcat with its sucker mouth proba- 
bly feeds on organisms in the bottom sediments and may also use nutrients from organic material in those sediments. The widemouth blindcat is probably an opportunistic feeder eating anything it can get in its mouth including young toothless blindcats. In samples taken from San Antonio wells, the toothless blindcats were twice as abundant as the widemouth blindcats.

The Texas blind salamanders have been observed eating almost all of the available invertebrates in the San Marcos pool of the aquifer. At the present time salamanders are being kept for study at Southwest Texas State University Aquatic Station. Thirty-three preadults and adults are being held in a distribution chamber of the artesian well. They are fed with aquifer invertebrates and apparently eat all that are placed in their holding vessels. In the laboratory, seven juveniles are being held in aquaria at $20-22^{\circ} \mathrm{C}$. These young are observed feeding on all invertebrates they can get in their mouths, often including the juvenile stages of shrimps or the smaller species of amphipods.

In the San Marcos Pool of the aquifer, the dytiscid beetle, Haideoporus texanus, is found. This form is troglobitic, lacking eyes and pigmentation. This beetle may be another predator in this system since dytiscids often are predaceous. It is relatively rare in samples and also is very small $(4-5 \mathrm{~mm})$. Individuals kept in aquaria have been observed feeding on dead shrimp, $P a$ laemonetes antrorum.

The fauna of the Edwards Aquifer consists of at least 35 to 40 species of troglobites, many endemic. Most organisms studied to date have been larger than 500 micrometers. In terms of richness of troglobitic species, this aquifer is apparently either the most diverse or one of the most diverse subterranean aquatic ecosystems in the world.

\section{RÉSUMÉ}

Des études récentes sur l'Aquifère d'Edwards, système de cavités karstiques du Texas, montrent l'existence d'une communauté de troglobies aquatiques extrêmement diversifiée.

Les prélèvements au niveau des puits et des sources apportent une vision nouvelle de la dynamique de ce système fascinant, qui est sans doute l'écosystème souterrain le plus diversifié connu actuellement dans le monde.

\section{LITERATURE}

ARNOW, T. 1959. Ground-water geology of Bexar County, Texas. Texas Board of Water Engineers Bull. 5911.

EDWARDS UNDERGROUND WATER DISTRICT, 1977. Information bulletin. Edwards Underground Water District, San Antonio, Texas.

HOLSINGER, J.R., and G. LONGLEY. 1980. The subterranean amphipod crustacean fauna of an artesian well in Texas. Smithsonian Contributions to Zoology No. 308, Smithsonian Institution Press, Washington, D.C.

LONGLEY, G. 1978. Status of Typhlomolge (=Eurycea) rathbuni, the Texas blind salamander. End. Species Rep. 2. U.S. Fish and Wildlife Service, Albuquerque, N.M.

LONGLEY, G., and H. KARNEI 1978a. Status of Satan eurystomus Hubbs and Bailey, the widemouth blindcat. Contract No. 14-16-0002-77-035, U.S. Fish and Wildlife Service.

LONGLEY, G., and H. KARNEI 1978b. Status of Trogloglanis pattersoni Eigenmann, the toothless blindcat. Contract No. 14-16-0002-77-035, U.S. Fish and Wildlife Service.

PUENTE, T.C., 1976. Statistical analysis of water-level, spring flow, and stream flow data for 
the Edwards Aquifer in South Central Texas. Edwards Underground Water District, San Antonio, Texas.

SWEET, S.S. 1978. The development of diversity in Texas cave salamanders. Abstract, National Speleological Society Annual Meeting, New Braunfels, Texas.

U.S. DEPARTMENT OF THE INTERIOR, 1973. Memorandum: Performance of Edwards Aquifer when subjected to increasing well discharge. Bureau of Reclamation (Southwest Region). Looseleaf. 


\title{
Structure et Fonctionnement des Écosystèmes du Haut-Rhône Français; VIII: Hydrologie de deux stations phréatiques dont l'eau alimente des bras morts*
}

\author{
J.L. Reygrobellet, J. Mathieu, R. Ginet, J. Gibert**
}

\section{SUMMARY}

We have been working since 1975 on phreatic stations providing two old meanders of the French river Rhône with interstitial water. The hydrological characteristics are quite different (see diagrams in the text):

- The one (station 2) is a particular under-flow circulating laterally to the river ("paraécoulement"'), which is closely subordinate with the varying level of the Rhône.

- The other (station 8 ) is the confluence of continental phreatic water proceeding from a Northeastern plateau (the "Dombes") with the hyporheic of the river Ain (eastern tributary of the Rhône). The Rhône has no influence on the characteristics of this second interstitial flow.

The physico-chemical disparity of these stations clearly appeared during two extremely opposite climatic periods; the inferences on resident populations are considered.

\section{INTRODUCTION}

Depuis 1975, notre Groupe de Recherche effectue une étude exhaustive du fleuve Rhône en amont de Lyon (Roux, 1976). Lors d'un travail préliminaire sur le milieu phréatique environnant, nous avions mentionné (Gibert, et al., 1977) la particularité de certaines eaux souterraines régionales, d'alimenter les restes d'anciens bras ou méandres du fleuve, constituant ainsi des étendues d'eau calme, plus ou moins proches du cours actif, et plus ou moins directement liées à lui suivant leur "âge". Ces "Lônes", successions de plusieurs écotones, forment des milieux originaux dont le secteur émergé fait depuis trois ans l'objet d'une recherche approfondie (Juget, et al., 1976, 1979); corrélativement, notre équipe travaille depuis la même époque sur l'écosystème interstitiel qu'elles confinent.

Pendant trois ans, nous avons donc essayé de cerner à la fois les caractéristiques hydrologiques de l'alimentation de ces lônes par de l'eau phréatique, et les phénomènes biologiques qui y sont liés.

Nous avons sélectionné deux stations d'étude:

- L'une (station 2, Gibert, et al., 1977) peut être considérée comme la

* Publication préliminaire à l'analyse faunistique qui figure à la suite de ce texte (IX).

** Biologie Souterraine, Université Claude Bernard LYON I, 43 Bd. du 11 Novembre 1918, 69622, Villeurbanne - France -. 
source de la "Lône des Pêcheurs"; cette dernière tire son eau du sousécoulement du Rhône et forme, rive gauche, sur plus de deux kilomètres, un véritable "affluent phréatique" du fleuve qui conflue avec lui légèrement en amont du barrage de Jons.

- L'autre (station 8, Gibert, et al., 1977), est constituée par le milieu interstitiel particulier de la 'Lône de l'Ile du Méant', localisée, rive droite, à l'emplacement de l'ancienne confluence de la Rivière l'Ain avec le Rhône.

L'objet de cette publication est de définir les biotopes où nous effectuons nos prélèvements de faune depuis 1975, dont les résultats sont exposés à la suite de ce texte (Gibert, et al., in this volume). Pour caractériser chacune des stations, nous utiliserons trois points de comparaison: le mode d'écoulement interstitiel, la composition granulométrique des sédiments, et la physico-chimie des eaux.

\section{MODE D’ÉCOULEMENT DES EAUX INTERSTITIELLES}

\section{A) "Lône des Pêcheurs"' (Station '2"')}

Depuis Dorgelo (1973), l'historique de la formation des lônes est bien connue. La lône des Pêcheurs s'est isolée du cours actif du Rhône vers 1860 . C'est actuellement la lône la mieux connue de notre groupe de travail, car son étude fait l'objet de la convention de recherche $n^{\circ}$ 76-55 du Ministère de l'Environnement et du Cadre de vie. Elle représente un complexe hydrographique voisin de celui du Waldrhein, situé en aval de Strasbourg (Alsace, France) dans la zone de confluence I11-Rhin (Ortcheit, 1975), qui est séparée du cours principal du fleuve depuis une date équivalente (1885).

Cependant, les fluctuations de niveau dûes aux manœuvres du barrage de Jons, en aval de la confluence Lône des Pêcheurs-Rhône, compliquent ici les phénomènes hydrologiques par rapport au système alsacien, créant des courants rythmiques de reflux à l'intérieur de la lône qui rendent mobile la zone où s'affrontent les eaux d'origine phréatique et les eaux fluviales. Malgré ce handicap, Juget, et al. (1978), utilisant la position relative de cette zone d'affrontement comme révélateur du débit phréatique, ont pu démontrer, pour les eaux alimentant la lône, leur totale dépendance par rapport au débit du Rhône lui-même.

Nous sommes donc en présence d'un “para-écoulement"' interstitiel latéral au Rhône, émergeant en station 2 et engendrant un cours d'eau superficiel "qui se trouve barré en aval par son propre émissaire" (Juget, et al, 1979). Le diagramme de la Figure 1 résume l'ensemble de ces données et fournit une représentation schématisée des courants souterrains environnant la station 2 .

\section{B) "Lône de l'île du Méant" (Station "8")}

Cette lône, dont la station 8 est l'une des zones d'alimentation, est la plus récente des lônes de la région (Dorgelo, 1973). Elle est en effet située, sur la rive droite, immédiatement en aval de la confluence Ain-Rhône qui a évolué en 
remontant vers l'amont. A son ancien emplacement se trouve actuellement ce bras, encore assez vif, dont la partie interstitielle est le lieu de convergence du sous-écoulement de l'Ain (il n'en est pas totalement coupé superficiellement) et de la nappe continentale descendant de la Dombes, perpendiculairement au Rhône, par la terrasse de La Valbonne. L'alimentation de cette lône est donc à la fois plus diffuse et plus complexe que celle de la Lône des Pêcheurs qui n'est qu'un sous-écoulement du Rhône vif.

Cette région a été particulièrement bien étudiée par trois offices régionaux: le Bureau de Recherches de Géologie Minière (B.R.G.M.), l'Agence de Bassin Rhône-Méditerranée-Corse, et le Service Régional d'Aménagement des Eaux (S.R.A.E.), que nous tenons à remercier pour les renseignements complets qu'ils nous ont aimablement fournis. La justification de leur intérêt est que la "Plaine de Miribel-La Valbonne" où se trouve notre station 8 est un réservoir d'eau potable d'une telle capacité qu'on envisage d'en faire la future zone de captage de l'agglomération lyonnaise. De nombreux rapports ont été rédigés par ces organismes depuis 1970, tant sur l'hydrologie du système aquifère (B.R.G.M., 1971 a, b; 1973, 1976) que sur la vulnérabilité aux pollutions de la nappe régionale (Agence de Bassin, 1974; Pinchaut, 1975). Récemment, le S.R.A.E. a même réalisé un forage d'essai à $-18 \mathrm{~m}$ (en vue d'irrigation) dans un secteur très proche de l'aire qui nous intéresse.

De ce fait, les sens d'écoulement, les débits moyens de l'aquifère et la vitesse de la nappe sont actuellement bien connus, ainsi que les importantes possibilités de pompage. Les données physico-chimiques moyennes du phréatique profond le sont aussi, et seront intéressantes à comparer avec les résultats obtenus sur l'interstitiel superficiel.

L'ensemble des informations fournies par ces rapports nous a permis d'établir, pour la station 8 également, un bloc-diagramme d'alimentation

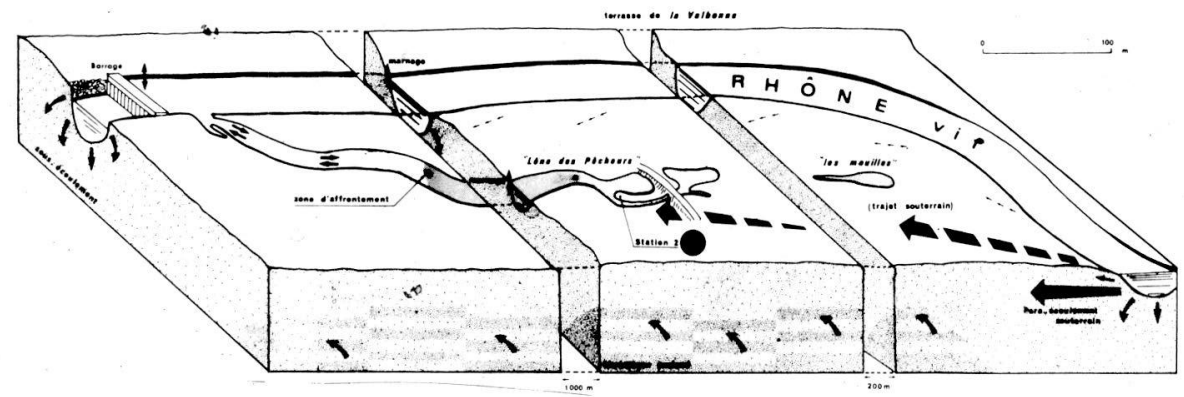

Fig. 1. Courants souterrains dans la zone d'alimentation de la Station 2

$\rightarrow$ : Infiltrations

-.. : courant hyporhéique

: para-écoulement principal 
(Fig. 2): c'est essentiellement, sur tout le cours amont de la Lône de l'ìle du Méant, un rééquilibrage du niveau piézométrique par les multiples remontées d'eau souterraine; ce n'est en effet qu'en périodes de hautes eaux que la lône est soumise aux courants des eaux superficielles de l'Ain.

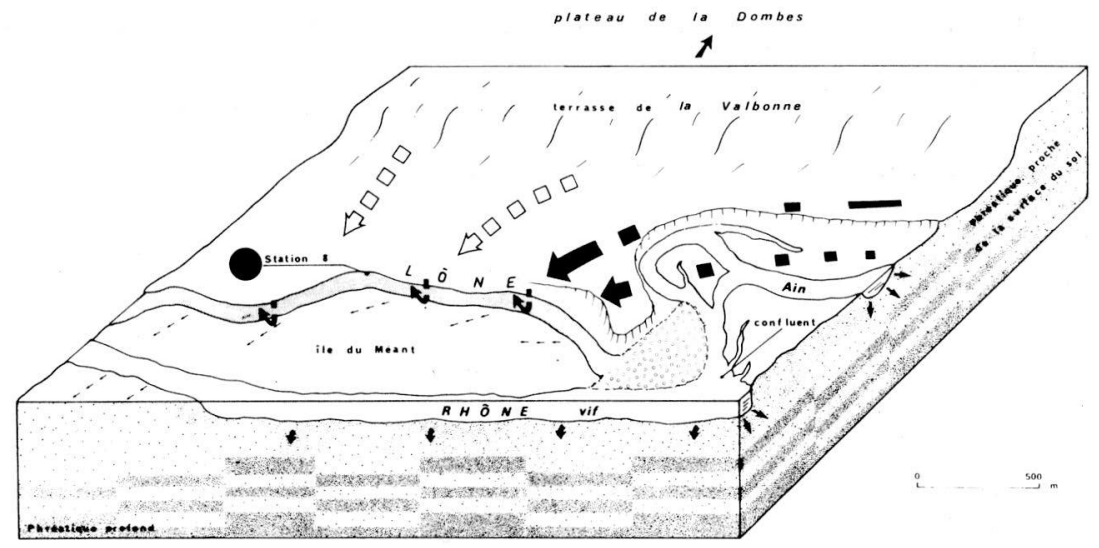

Fig. 2. Courants souterrains dans la zone d'alimentation de la Station 8

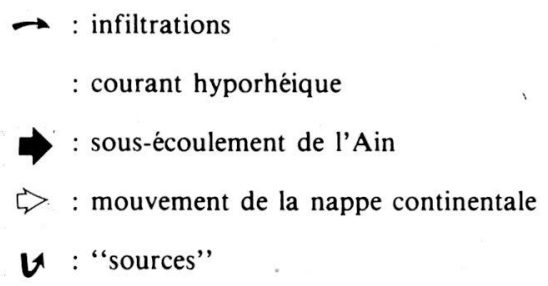

\section{GRANULOMÉTRIE COMPARÉE DES DEUX STATIONS}

Les prélèvements granulométriques effectués au début de la campagne (1975) sont analysés Figure 3. Les particules assez fines (sablons), dont l'influence sur la répartition de la méïofaune ne devrait pas être négligeable, sont mieux représentées en station 8 (pic à $0,18 \mathrm{~mm}$.) et traduisent un débit moyen plus faible.

\section{ANALYSE PHYSICO-CHIMIQUE DES EAUX}

\section{A) Mode de Prélèvement et Méthode d'Analyse}

Après chaque prise de faune, un échantillon d'eau est prélevé, à $60 \mathrm{~cm}$. environ dans le sédiment, à travers la sonde crépinée de type Bou-Rouch restée en 
place (Bou et Rouch, 1967; Bou, 1974). L'eau interstitielle est prise, lentement, au moyen d'une pompe péristaltique adaptée sur un tube "Rilsan" (pompe Wab); ce système est utilisé en écologie phréatique depuis Husmann (1974). Les flacons à double bouchage sont placés en bac isotherme et ramenés au Laboratoire. Quelques mesures sont effectuées in situ: Température, $\mathrm{pH}$, Oxygène. Les autres sont faites au Laboratoire selon les méthodes d'analyse suivantes: lin.

- Oxydabilité au permanganate: détermination à chaud en milieu alca-

- Titre alcalimétrique complet: titrimétrie par $\mathrm{HCl}$ en présence d'indicateur mixte.

- Calcium et Magnésium: dosage simultané par complexométrie à l'E.D.T.A. sur un même échantillon (Rodier, 1975).

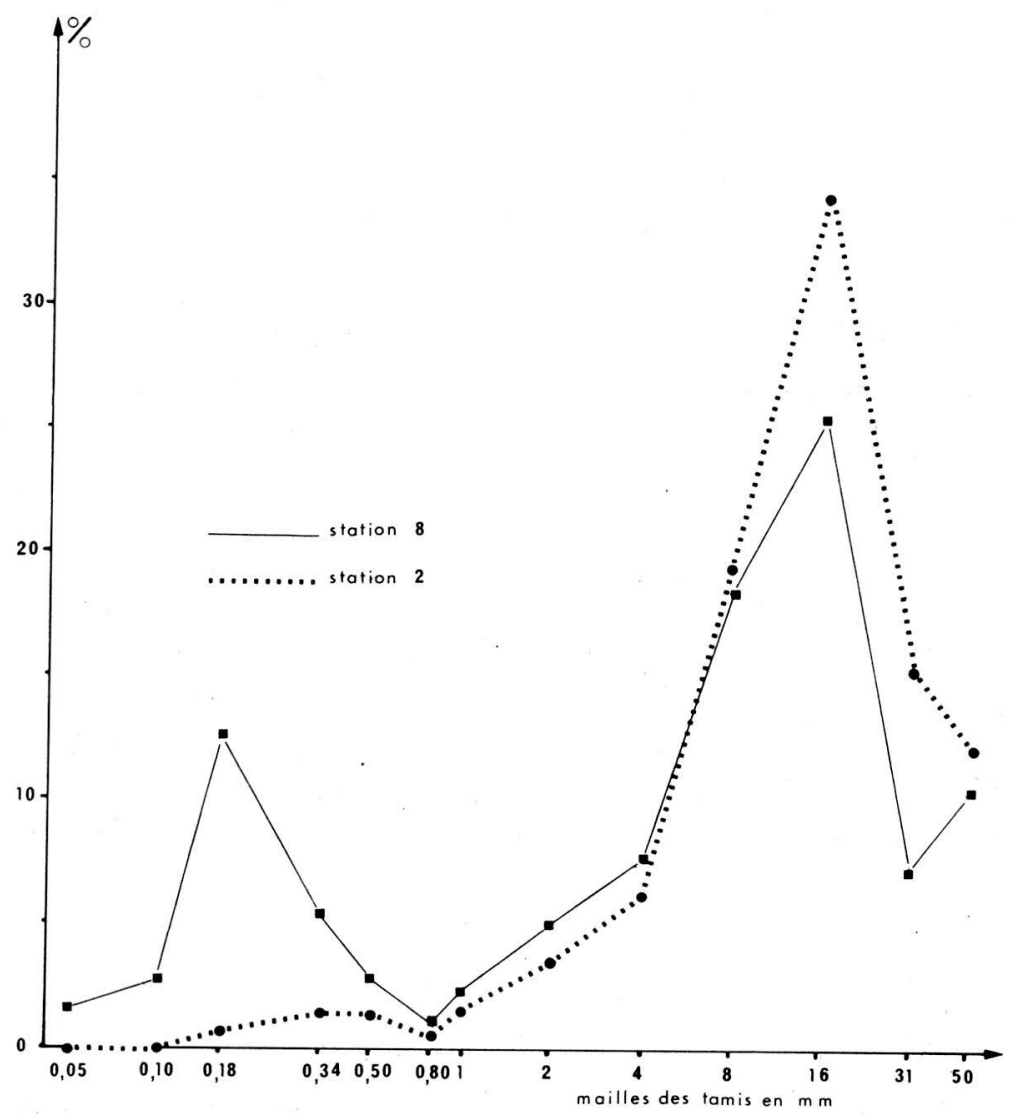

Fig. 3. Granulométrie comparée des stations 2 et 8 . 
- Chlorures: titrimétrie au nitrate mercurique avec indicateur (Diphénylcarbazone).

- Sulfates: dosage par turbidimétrie (Rodier, 1975).

- Nitrates: spectrophotométrie au salicylate de Soude (Rodier, 1975). sver III.

- Orthophosphates: photocolorimètre Hach IR-DR; méthode au Pho-

- Silice dissoute: photocolorimètre Hach IR-DR; méthode aminoacide.

- Fer total: photocolorimètre Hach IR-DR; méthode à la ferrozine.

\section{B) Résultats}

En régime moyen, les stations ne manifestent pas de différences flagrantes:

- le pH est toujours voisin de la neutralité;

- les écarts de température observés sur un cycle annuel ne dépassent pas $6^{\circ} \mathrm{C}$; notons cependant qu'ils sont plus marqués en station 2, car les températures basses, décalées, mais induites par celles du Rhône vif, y sont nettement inférieures à celles de la station 8 :

- l'oxydabilité, en moyenne faible (entre 0 et 1 ), est légèrement supérieure en station 2 ;

- les eaux sont toutes deux très bicarbonatées-calciques $\left(\mathrm{HCO}_{3}^{-}\right.$toujours supérieur à $300 \mathrm{mg} / \mathrm{L} ; \mathrm{Ca}^{++}$entre 80 et $100 \mathrm{mg} / \mathrm{L}$ );

- la seule très forte disparité s'exprime au niveau des teneurs moyennes en silice dissoute; elles sont beaucoup plus élevées (au moins le double) en station 2.

En définitive, c'est à la faveur de deux épisodes hydrologiques extrêmement différents (1976 et 1977) que nous avons pu constater l'originalité de chacune des stations. En effet:

$1^{\circ}$ ) la pluviosité de 1976 fut si faible qu'elle fit subir à la région une sécheresse exceptionnelle pendant les mois d'été (le débit moyen du Rhône pour l'année tomba à $405 \mathrm{~m}^{3} / \mathrm{s}$ ). En conséquence, le para-écoulement souterrain de la rive gauche subit un net "tarissement"; le barrage de Jons maintenant artificiellement un niveau anormalement haut pour un tel débit, les eaux superficielles refluèrent jusqu'en amont de la lône où elles stagnèrent plus de trois mois, contaminant la zone interstitielle.

Pendant ce temps, aucune modification n'intervenait dans le régime hydrique de la station 8 .

$2^{\circ}$ ) dès l'hiver, les précipitations s'accumulèrent, et le début de l'année 1977 fut le cadre d'une crue extrêmement forte du fleuve (du 6 février à la fin du même mois); le pic de crue se situa le 12 février avec un débit de 2540 $\mathrm{m}^{3} / \mathrm{s}$. Depuis cet instant, le Rhône occupa la totalité de son lit majeur, retrouvant ses trajets du début du siècle. Les deux lônes furent donc balayées, pendant trois semaines, par ce flux chargé de limons. La pluviosité se maintint très forte, même après le retour du fleuve dans son lit normal; l'été fut si humide que 1977 est actuellement l'une des deux années les plus arrosées du sì̀cle. Les hauteurs d'eau tombées pendant le mois de juillet à la station -Météo de Lyon-Gerland constituent même un record absolu pour la région avec 191,4 mm. Durant le reste de l'année, les nappes furent hautes et le débit 
phréatique important; le Rhône accusa une très forte moyenne générale avec $728 \mathrm{~m}^{3} / \mathrm{s}$ (débit annuel moyen 1920-1976: $584 \mathrm{~m}^{3} / \mathrm{s}$ ).

Pendant ces deux périodes, l'évolution de la plupart des éléments majeurs de l'eau a été suivie; nous avons extrait de nos résultats six courbes qui résument les deux types de "comportement hydrologique" des stations en ces circonstances (Fig. 4).

On peut y faire les constatations suivantes:

- Température: oscillant habituellement autour d'une moyenne de $11,5^{\circ} \mathrm{C}\left( \pm 3^{\circ}\right)$, la température de la station 2 a subi une très forte hausse pendant la sécheresse de 1976 , avec un pic en juillet à $24,8^{\circ} \mathrm{C}$. Ce pic est dû à la stagnation des eaux dans le sédiment. Corrélativement, la station 8 reste très tamponnée par la nappe continentale et ne dépasse pas un maximum de $14^{\circ} \mathrm{C}$.

Après la crue de 1977 , le fort débit interstitiel ramène les températures dans leur "fourchette" habituelle, la station 8 restant toujours plus chaude en hiver.

- Conductivité électrique: c'est une variable facile à mesurer et qui traduit bien la minéralisation globale de l'eau. Elle met ici en évidence la chute brutale, pendant les trois mois de sécheresse, de la plupart des éléments caractéristiques de l'eau interstitielle en station 2. Après la reprise d'un certain débit souterrain (dès novembre 1976), le milieu récupère très vite sa minéralisation moyenne.

Notons qu'après la forte pluviosité du début de l'année et la crue de février 1977, la station 8 qui n'avait pas semblé notablement affectée par la sécheresse précédente, subit une nette hausse de conductivité dont le sousécoulement de l'Ain, vu la promptitude de la réaction, est sans doute le responsable.

- Sulfates - Calcium: nous avons choisi ces deux ions antagonistes car ils sont tous deux les indicateurs d'un certain type d'eau. En effet, le Rhône superficiel est très chargé en sulfates, drainant dans son cours supérieur (Bassin du Léman) des bancs de Gypse triasique (Juget, et al., 1976); les valeurs sont constamment voisines de $40 \mathrm{mg} / \mathrm{L}$. Nous avons déjà signalé que pendant la sécheresse, le barrage, créant un "faux niveau", fit refluer les eaux jusqu'en amont de la Lône des Pêcheurs. Le brusque pic de sulfates en station 2, et, corrélativement, la retombée extrêmement rapide du Calcium caractérisant l'eau interstitielle, sont la preuve de la contamination du milieu phréatique par les eaux du fleuve... Dès novembre 1976, le "lavage" que produisit la reprise du para-écoulement rendit très vite à la station 2 ses faibles valeurs en sulfates (peu différentes de celles qu'on observe en station 8 ) et ses très fortes concentrations en Calcium $(111,6 \mathrm{mg} / \mathrm{L}$ à cette date).

Là encore, la station 8 resta d'une totale stabilité pendant l'épisode sec. Cependant, après une courte baisse du Calcium immédiatement après la crue (contamination superficielle constatée également en station 2), elle accusa un ressaut très important qui lui fit rejoindre les valeurs élevées de la station 2 . Ceci est sans aucun doute le fait du sous-écoulement de l'Ain, descendant du karst lessivé par les pluies, et participe pour sa plus grande partie à l'augmentation de la conductivité électrique citée précédemment. 

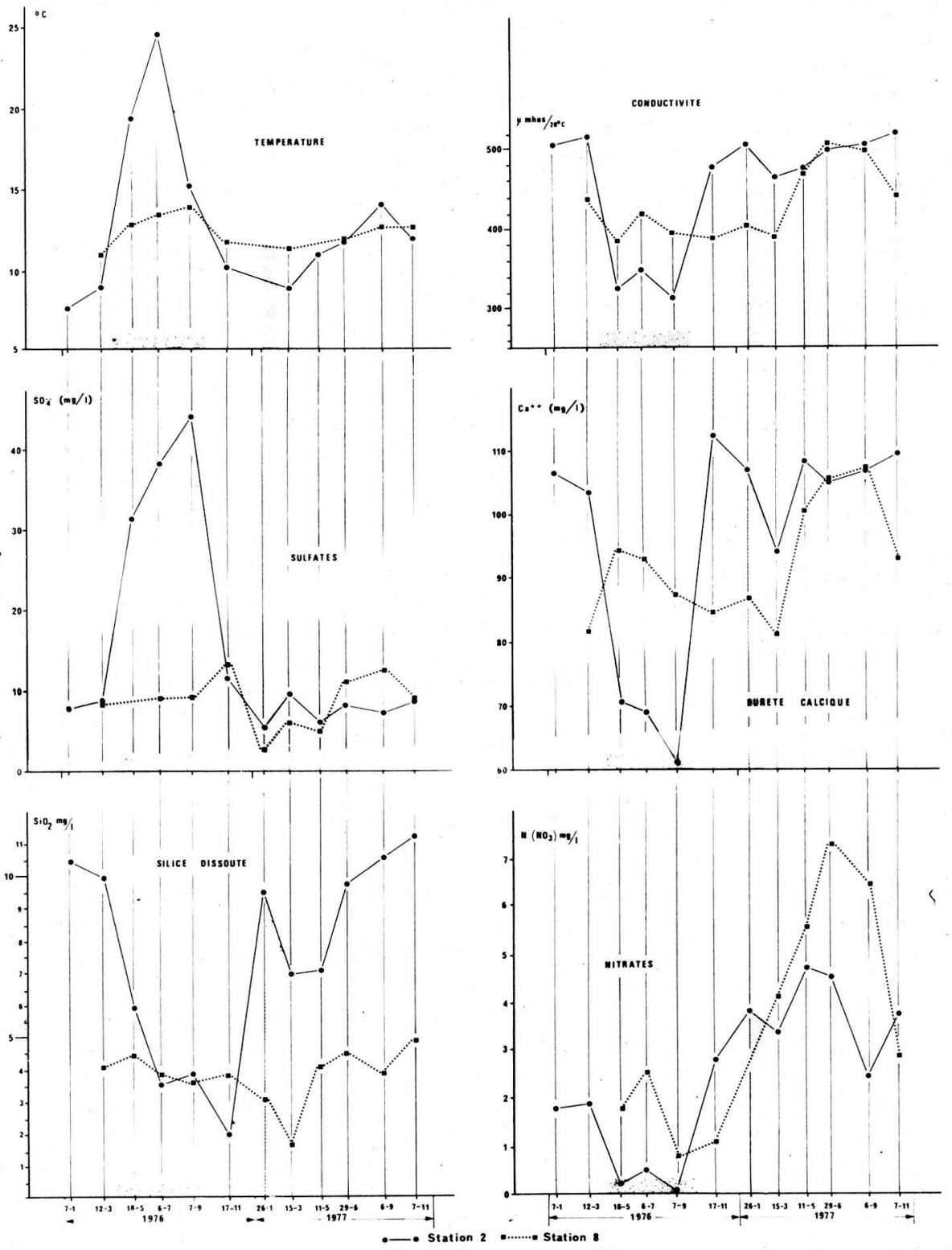

Fig. 4. Évolution de quelques éléments majeurs de l'eau des stations 2 et 8 au cours des épisodes hydrologiques très différents de 1976 et 1977. 
- Silice et nitrates: ces deux derniers éléments manifestent encore les bouleversements qui se sont opérés pendant deux ans dans l'interstitiel régional:

En station 2, la teneus en silice est environ deux fois supérieure à celle de la station 8; elle a même pu être utilisée, avec le Calcium, comme indicateur du para-écoulement de la rive gauche par comparaison avec l'eau du Rhône vif. Elle présente habituellement dans la Lône des Pêcheurs un gradient amont/aval décroissant dû à l'action progressive de la végétation aquatique (Juget, et al., 1976). Pendant les mois secs, ce gradient a totalement disparu, car les valeurs tombent brusquement au niveau de celles de la station 8 , trahissant à nouveau l'invasion de ce secteur par les eaux du Rhône. Encore une fois, dès la reprise du para-écoulement, les taux remontent en flèche. La courte contamination superficielle déjà observée pour le Calcium se manifeste également après la crue de 1977.

- Les nitrates sont en général voisins dans les deux stations; les concentrations en sont proches de celles observées en Angleterre par Gledhill (1977) dans cette frange supérieure du milieu interstitiel. Elles baissent fortement en station 2 pendant la sécheresse, l'eau du Rhône pauvre en nitrates accupant le sédiment.

Mais le plus important phénomène observé est l'augmentation très forte des taux en station 8 pendant le régime phréatique fort, qui participe également à la hausse de la conductivité électrique de l'eau. Ceci représente, compte tenu d'un temps de latence prévisible (le pic est en juillet), la réponse de la nappe aux pluies du début de l'année. En effet l'augmentation du débit général agit sur l'interstitiel profond dont on sait (Agence de Bassin, 1974; S.R.A.E., 1977) que les teneurs en nitrates sont très élevées dans cette plaine de "Miribel-La Valbonne"; elles avoisinent $30 \mathrm{mg} / \mathrm{L}$ à $-15 \mathrm{~m}$.

\section{COMMENTAIRES}

Ce qui précède démontre l'importance de l'analyse physico-chimique en écologie phréatique; ce n'est que trois ans après le début de notre travail sur ces deux stations que nous commençons à bien connaître leur régime hydrologique et les conditions de milieu qu'elles présentent.

Nous avons pu constater la très grande variabilité des composantes de la station 2, qu'elles soient hydrauliques ou physico-chimiques. Au contraire, la station 8 parait extrêmement tamponnée par la présence de la nappe régionale, jusqu'à un certain seuil où le sous-écoulement de l'Ain peut manifester son originalité $\left(\mathrm{Ca}^{++}, \mathrm{Fig}\right.$. 3). Il semble que le vaste réservoir de la plaine de Miribel-La Valbonne, à circulation lente et régulière (débit: $400 \mathrm{1} / \mathrm{sec}$. pour une vitesse moyenne de 3,5 mètres par jour) représente un élément de stabilité incontestable pour les biocénoses interstitielles résidant dans cette station; par opposition, le régime de la station 2, étroitement tributaire du débit du Rhône vif et compliqué par la présence du barrage de JONS, semblerait ne convenir qu'à des organismes supportant des conditions instables.

Ces deux biotopes peuvent cependant, pour des raisons différentes (cf. 
plus haut), constituer chacun une zone privilégiée d'échanges entre les secteurs hypogé et épigé. L'étude faunistique $(c f$. IX) montrera si leurs facteurs de milieu si opposés ont exercé une influence sur la composition des biocénoses.

\section{RÉSUMÉ}

Deux stations phréatiques alimentant en eau interstitielle d'anciens méandres du Rhône ont été suivies depuis 1975. Leurs modes hydrologiques sont très différents (ils sont schématisés sur deux blocs diagrammes):

- l'une (station 2) est un écoulement souterrain parallèle au cours du fleuve, très lié à ses variations de débit, et circulant dans un substrat à granulométrie assez grossière (paraécoulement);

- l'autre (station 8 ) résulte de la confluence de la nappe continentale provenant du plateau de la Dombes (au Nord-Est) avec le sous-écoulement de l'Ain, affluent du Rhône. Les variations de débit du fleuve n'influent pas sur cet écoulement phréatique.

Une étude physico-chimique a permis, à l'occasion de conditions climatiques exceptionnelles (sécheresse-inondation), de confirmer la grande stabilité des facteurs du milieu en station 8 ; par contre, ceux de la station 2 présentent une variabilité originale pour un biotope interstitiel.

\section{OUVRAGES CITÉS}

AGENCE DE BASSIN Rhône - Méditerranée - Corse. 1974. Protection des nappes alluviales - contre la pollution: Site alluvial de l'Est Lyonnais: Etude générale: 190p, 15 cartes.

BOU, C. 1974. Recherches sur les eaux souterraines interstitielles. Ann. Spéléol. 29, 4:611-619.

BOU, C., et ROUCH R. 1967. Un nouveau champ de recherches sur la faune aquatique souterraine. C.R. Acad. Sci. Paris 265:369-370.

B.R.G.M. 1971a. Note de synthèse résumant les principaux enseignements tirés des observations piézométriques: rapport 71. S.G.N. 129 JAL.

B.R.G.M. 1971b. Interprétation de pompages d'essais effectués danş la plaine de l'Est Lyonnais. Rapport 71, S.G.N. 261 JAL.

B.R.G.M. 1972. Interprétation de pompages d'essais effectués dans la plaine de l'Est Lyonnais. Rapport 72, S.G.N. 113 JAL.

B.R.G.M. 1973. Synthèse des connaissances sur le système aquifère de l'Est Lyonnais. Rapport 73, S.G.N. 199 JAL.

B.R.G.M. 1976. Réflexions sur le système aquifère de l'Est Lyonnais. Rapports 76, S.G.N., 355 JAL. - 76, S.G.N. 447 JAL.

DORGELO, J. 1973. Etude de la végétation dans les anciens lits du Rhône et des moustiques qui lui sont liés, de Lyon au confluent de l'Ain. Dipl. Et. Sup. Univ. Claude Bernard, Lyon.

GIBERT, J., GINET, R., MATHIEU, J., REYGROBELLET, J.L., et SEYED-RE̊IHANI, A., 1977. Structure et fonctionnement des écosystèmes du Haut-Rhône français. IV - le peuplement des eaux phréatiques; premiers résultats. Ann. Limnol. 13, 1:83-97.

GLEDHILL, T. 1977. Numerical fluctuations of four species of subterranean amphipods during a five year period. Crustaceana Suppl. 4:144-152.

HUSMANN, S. 1974/75. Versuche zur Erfassung der vertikalen Verteilung von Organismen und chemischen Substanzen im Grundwasser von Talauen und Terrassen; Methoden und erste Befunde. Int. J. Speleol. 6:271-302.

JUGET, J., AMOROS, C., GAMULIN, D., REYGROBELLET, J.L., RICHARDOT M., RICHOUX, Ph., et ROUX C. 1976. Structure et fonctionnement des écosystèmes du Haut-Rhône français. II - Étude hydrologique de quelques bras morts. Premiers résultats. Bull. Ecol. 7, 4:479-492.

JUGET, J., YI, B.J., ROUX, C., RICHOUX, Ph., RICHARDOT-COULET, M., REYGROBELLET, J.L., et AMOROS C. 1979. Structure et fonctionnement des écosystèmes du Haut-Rhône français. VII - Le complexe hydrographique de la Lône des Pêcheurs (ancien méandre du Rhône). Rev. Suisse Hydrol. 41/2:395-417. 
ORTSCHEIT, A. 1975. Le complexe hydrographique du confluent Ill - Rhin en aval de Strasbourg, ses originalités hydrobiologiques. Thèse, 888. U.E.R. Sc. Pharma. Strasbourg.

PINCHAUT, R. 1975. Protection des nappes alluviales: orientations et conclusions des études du site alluvial de l'est lyonnais. Bull. Inform. Comité et Agence de Bassin RhôneMéditerranée-Corse, 9: 34-50.

RODIER, J. 1975. L'Analyse de l'eau. Eaux naturelles, eaux résiduaires, eaux de mer. Dunod ed., Paris, 628 p.

ROUX, A.L. 1976. Structure et fonctionnement des écosystèmes du Haut-Rhône français. I Présentation de l'étude. Bull. Ecol. 7, 4:475-478.

S.R.A.E. RHÖNE-ALPES. 1977. A.S.A. d'irrigation de l'Ain - Casier de Balan: Reconnaissance hydrogéologique. Ministère Agriculture France (rapport interne). 



\title{
Structure et Fonctionnement des Ecosystèmes du Haut-Rhône Français; IX: Analyse des peuplements de deux stations phréatiques alimentant des bras morts $\left(^{*}\right)$
}

\author{
J. Gibert, R. Ginet, J. Mathieu, \\ et J.L. Reygrobellet(**)
}

\begin{abstract}
SUMMARY
Two phreatic stations providing old meanders of the French river Rhône ("Lônes") with interstitial water have been studied for three years. The samples (100 liters of water) have been collected by the Bou-Rouch method at $60 \mathrm{~cm}$ deep in the sediment.

The analyses of populations show that the biocenoses of the two stations are quite different: The one (Station 2) is rather specialized; most of the species are troglobitic ( $80 \%$ of the whole biomass; the only Amphipod, Niphargopsis casparyi, represents $67 \%$ of this biomass). The other (Station 8) is very diversified; the seven dominant groups are all epigean animals.

Population numbers have changed during the three years of sampling. Fluctuations have been observed in station 2, but the total numbers were quite similar in 1975 and 1977 . On the contrary, station 8 shows an "exponential" type of growth generated by epigean organisms, while troglobitic species remained unchanged.
\end{abstract}

A la suite d'une étude préliminaire (Gibert et al., 1977) sur le peuplement des eaux interstitielles de la Région Lyonnaise, les phénomènes biologiques liés à l'alimentation des bras morts (ou "Lônes") du Haut-Rhône par de l'eau phréatique, nous sont apparus comme les plus importants à approfondir. Pour cela, nous avons suivi pendant trois ans l'évolution des peuplements de deux stations (station 2 et 8 , in Gibert et al., 1977) alimentant des lônes dont la formation n'est pas contemporaine et dont les caractéristiques hydrologiques diffèrent sensiblement. La présentation détaillée de ces deux stations (diagrammes de circulations des eaux souterraines) est développée dans Reygrobellet et al. (in this volume).

Rappelons simplement que l'une (station 2) est située sur la rive gauche, au niveau du retour à l'état superficiel du sous-écoulement du Rhône; ceci donne naissance à un affluent d'origine interstitielle circulant parallèlement au fleuve sur plus de deux kilomètres, avant de confluer avec lui légèrement en amont du barrage de Jons (Juget et al., 1976, 1979). L'autre (station 8) se trouve, sur la rive droite du fleuve, dans la zone d'alimentation d'une lône de

(*) Publication faisant suite à l'étude hydrologique et physico-chimique des deux stations (Reygrobellet et al. 1981, dans ce volume).

${ }^{(* *)}$ Laboratoire de Biologie Souterraine, Université Claude-Bernard - LYON I, 43 Bd du 11 Novembre 1918, 69622 - VILLEURBANNE. 
formation plus récente, qui circule dans l'ancien emplacement du confluent de l'Ain avec le Rhône (carte in Gibert et al., 1977). Cette lône tire la majeure partie de son eau à la fois du sous-écoulement de l'Ain et de l'aquifère descendant du plateau de la Dombes.

\section{MATÉRIEL UTILISÉ ET MÉTHODE DE TRAVAIL}

Le matériel employé est le système de pompage "Bou-Rouch" (Bou et Rouch, 1967; Bou, 1974). Les prélèvements bimestriels, de 100 litres d'eau, s'effectuent à environ $60 \mathrm{~cm}$ sous la surface du sédiment. Etant donné le volume d'eau puisée, nous ne ferons pas référence aux classifications établies par Husmann (1974) ou Ronneberger (1975); pour notre part, nous estimons avoir, en moyenne, échantillonné entre 20 et $100 \mathrm{~cm}$ de profondeur.

La période d'échantillonnage va de début juin 1975 à janvier 1978. Elle recouvre des épisodes hydrologiques très différents, dont les conséquences physico-chimiques ont été mentionnées précédemment (Reygrobellet et al., in this volume). Il est intéressant de voir si leur impact a aussi été ressenti au niveau faunistique.

\section{RÉSULTATS}

\section{Structure générale des Biocénoses}

Pour les 3 ans de prélèvement, et pour chaque grand groupe systématique (1) des stations 2 et 8 , nous avons représenté (fig. 1):

- d'une part, l'abondance relative (A),

- d'autre part, la biomasse relative (B), calculée par l'intermédiaire des "volumes moyens." Cette valeur est déterminée de la façon suivante: dans chacun des groupes systématiques, un échantillon d'individus de tailles différentes est mesuré sous la loupe binoculaire; si l'on assimile la morphologie des individus à une forme géométrique (cylindre, cube, parallélipipède selon le cas), on peut ainsi définir le volume approximatif, puis la biomasse de l'échantillon, en considérant que la masse volumique des animaux aquatiques est voisine de l'unité.

Cette façon de procéder permet d'avoir une meilleure idée de l'influence écologique de ces groupes dans la biocénose, l'utilisation de la seule abondance relative pouvant masquer l'importance de certains organismes à biomasse forte (Renaud-Debyser, 1963; Williams et Hynes, 1974).

Il existe une trentaine de groupes systématiques dans chaque station, mais les 2 peuplements sont sensiblement différents (fig. 1):

- la station 8 possède 8 groupements principaux (2) aussi bien en abon-

(1) Les groupes systématiques ne sont pas réellement équivalents; ils représentent plus une entité écologique qu'un niveau de détermination.

(2) Les abondances relatives des autres groupements sont inférieures à $2 \%$. 

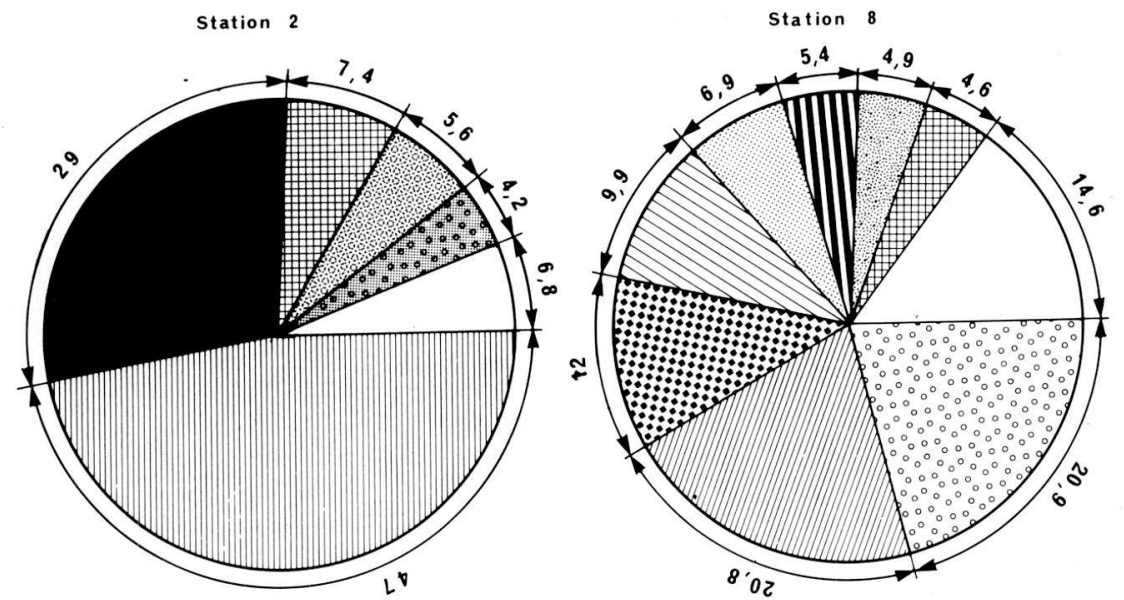

A
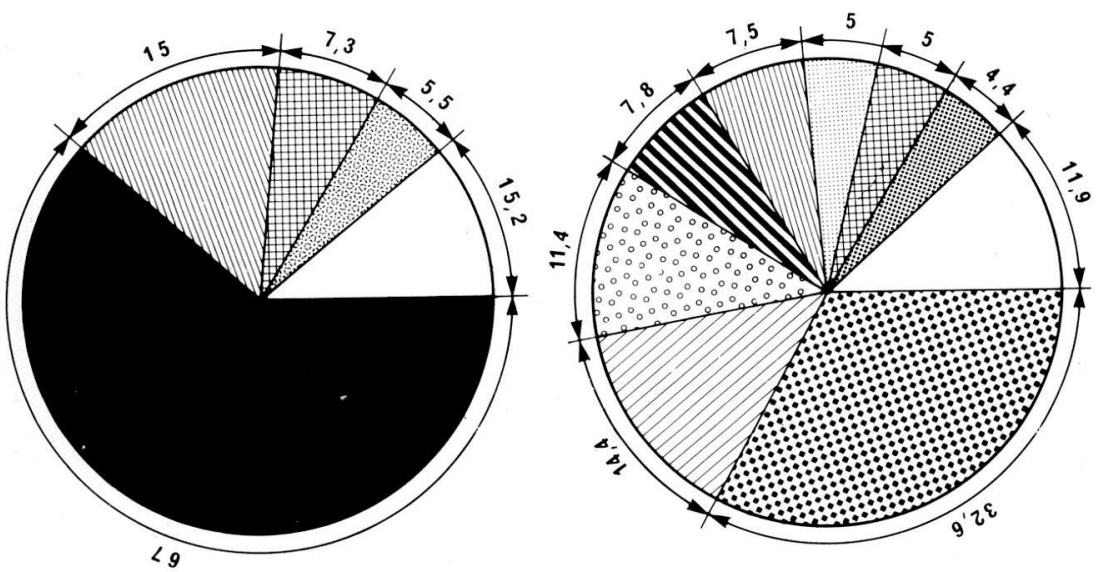

B
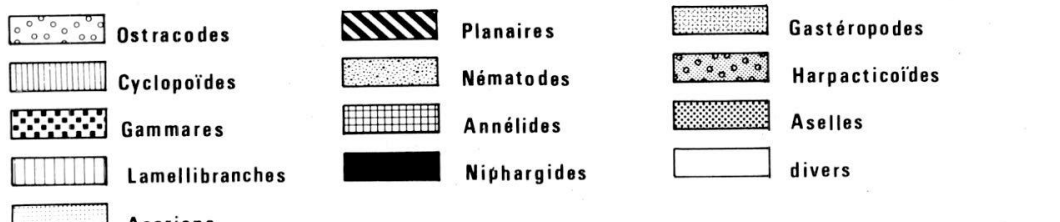

Annélides

Niphargides

divers

Fig. 1. Structure générale des biocénoses des stations 2 et 8 A: abondance relative

B: biomasse relative approchée 
dance qu'en biomasse relatives (dans le premier cas 6 sont dominants, 7 dans le second); l'expression en biomasse (B) fait rétrograder Cyclopoïdes et Ostracodes; les Nématodes disparaissent même au profit des Aselles.

- la station 2, au contraire, n'a que 5 groupements principaux (dont 4 sont dominants pour les deux types de calcul). Deux de ces groupements représentent à eux seuls $80 \%$ de toute la biocénose: les "Niphargides" (3) nettement dominés par les Cyclopoïdes lorsque leur nombre est exprimé en abondance relative, prennent toute leur signification dans le peuplement si leur pourcentage est exprimé en biomasse (67\%).

\section{Évolution des Biocénoses}

Nous avons porté sur un histogramme (fig. 2) les abondances relatives des groupes principaux cités au premier paragraphe, pour chacune des trois années de prélèvements.

Là encore, de grosses différences apparaissent:

- en station 2, les rangs de ces groupes sont assez réguliers, mais on note une baisse importante du nombre total d'individus en 1976, due à une forte diminution des Cyclopoïdes. Ce n'est pas le cas des Niphargides qui sont alors le groupe le mieux représenté. En 1977, après la grande crue de février, le peuplement retrouve sa valeur globale de 1975, mais les Annélides et les Harpacticoïdes ont augmenté, alors que les Niphargides n'ont plus que la moitié de leur effectif des deux années antérieures.

- la station 8 , très peu peuplée au début des prélèvements (un millier d'organismes seulement, où larves de Diptères et Gammares l'emportent) voit son peuplement quintupler en 1976, avec inversion des rangs. En 1977, le nombre total passe à 22.000 individus; cette progression régulière et "l'explosion démographique" de la dernière année seront analysées plus loin à un niveau systématique plus élevé.

\section{Liste Faunistique}

Nous joignons en Annexe de ce texte une liste systématique pour chacune des stations, dans l'état où se trouvent actuellement nos déterminations. Les niveaux de détermination ne sont pas tous équivalents, mais les groupes les plus abondants sont, pour la plupart, déterminés jusqu'à l'espèce; les populations en sont donc comparables. Cette liste indique, outre la "présence/absence" des unités systématiques, une estimation de leur représentation au sein du peuplement (celle-ci est exprimée en 4 classes qui tiennent à la fois compte de la fréquence et de la constance dans les prélèvements).

Un certain nombre d'informations importantes peuvent être dégagées: à ce niveau de détermination, les nombres d'unités systématiques présentes

(3) Ce terme, créé pour améliorer la rapidité de nos tris, regroupe en fait les deux genres Niphargus et Niphargopsis; la population de Niphargopsis casparyi correspond à $99,6 \%$ de ce groupe. 
dans les deux stations sont toujours très voisins (station 2: 115; station 8: 120). Cependant, pour la plupart des grands groupes (Nématodes, Oligochètes, Gastéropodes, Lamellibranches, Ostracodes, Copépodes, Amphipodes, ...), il y a très peu d'affinités entre les deux peuplements; deux exemples précis l'illustrent:
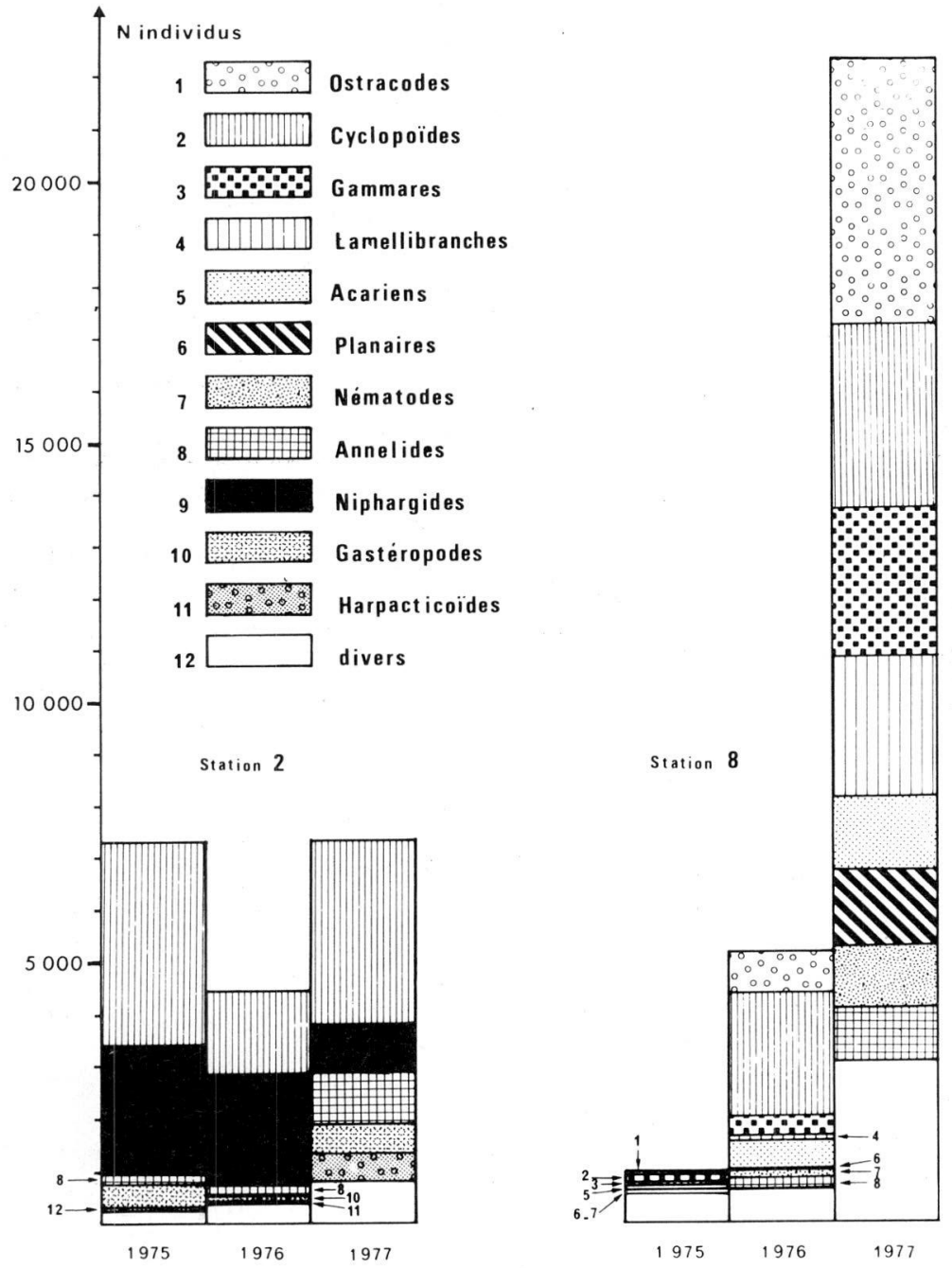

Fig. 2. Evolution de la présence des grands groupes faunistiques dans les stations 2 et 8 au cours des trois années de prélèvements. 
(a) Les troglobies

La station 2 en possède 17 unités systématiques; la station 8, 14: quoique légèrement plus élevés en station 2 , les nombres ne sont pas sensiblement différents. Cependant, ce sont les Gammaridae qui constituent pratiquement à eux seuls le nombre des troglobies de la station 8 , alors que la station 2 héberge beaucoup de très petites espèces phréatobies et troglobies, contre deux représentants seulement de la macrofaune (Niphargopsis et Niphargus).

(b) Les Oligochètes

On note un nombre d'espèces plus important en station 8 qu'en station 2 (34 contre 22). Peu d'espèces sont communes à ces deux stations ( 7 pour 46 déterminées); beaucoup sont banales et relativement bien représentées en station 8. En station 2 par contre, on remarque l'abondance de Trichodrilus leruthi, connu jusqu'à présent par quelques exemplaires récoltés dans un puits de Belgique (J. Juget, communication personnelle). On rencontre également d'autres espèces interstitielles, comme Marionina argentea ou Pristina foreli. Ces organismes étant essentiellement limivores, il est possible de relier les différences observées entre ces biocénoses avec celles de la granulométrie des deux stations; la plus forte concentration de particules assez fines (pic à 0,18 $\mathrm{mm}$ ) à la station 8 peut en effet jouer un rôle favorisant la diversité du peuplement de ces Oligochètes.

\section{Évolution au cours du temps de populations particulièrement bien représentées}

Nous avons observé des évolutions numériques différentes dans les deux peuplements (paragraphe B) pendant les trois ans de prélèvements, l'une fluctuante (2) et l'autre de type "exponentiel" (8). Les niveaux de déterminations étant insuffisants sur les diagrammes pour en suivre les détails, nous avons étudié les variations de quelques populations très abondantes dans chacune des stations:

(a) Niphargopsis casparyi

Cette espèce, connue depuis peu dans la Région Lyonnaise (Gibert et al., 1977), occupe à elle seule $67 \%$ de la biomasse totale de la station 2; les fluctuations de la population sont présentées figure 3.

Pour les deux premières années, les effectifs les plus importants sont en été (juillet/septembre), et semblent être relativement synchrones avec les maximums de température (4).

En février 77, la crue du Rhône balaye tọute la lône pendant trois semaines; elle est suivie d'un fort débit interstitiel qui se maintient pendant toute cette année très pluvieuse. Le premier prélèvement possible après la crue $(15 / 3 / 77)$ révèle la diminution brutale de la population (18 individus seule-

(4) Il faut signaler que ce phénomène s'est produit de la même façon pendant la grande sècheresse estivale de 1976, au cours de laquelle la station a été envahie par les eaux de surface, très riches en sulfates, refluant depuis le fleuve vers l'amont de la lône (Reygrobellet et al., in this volume). 


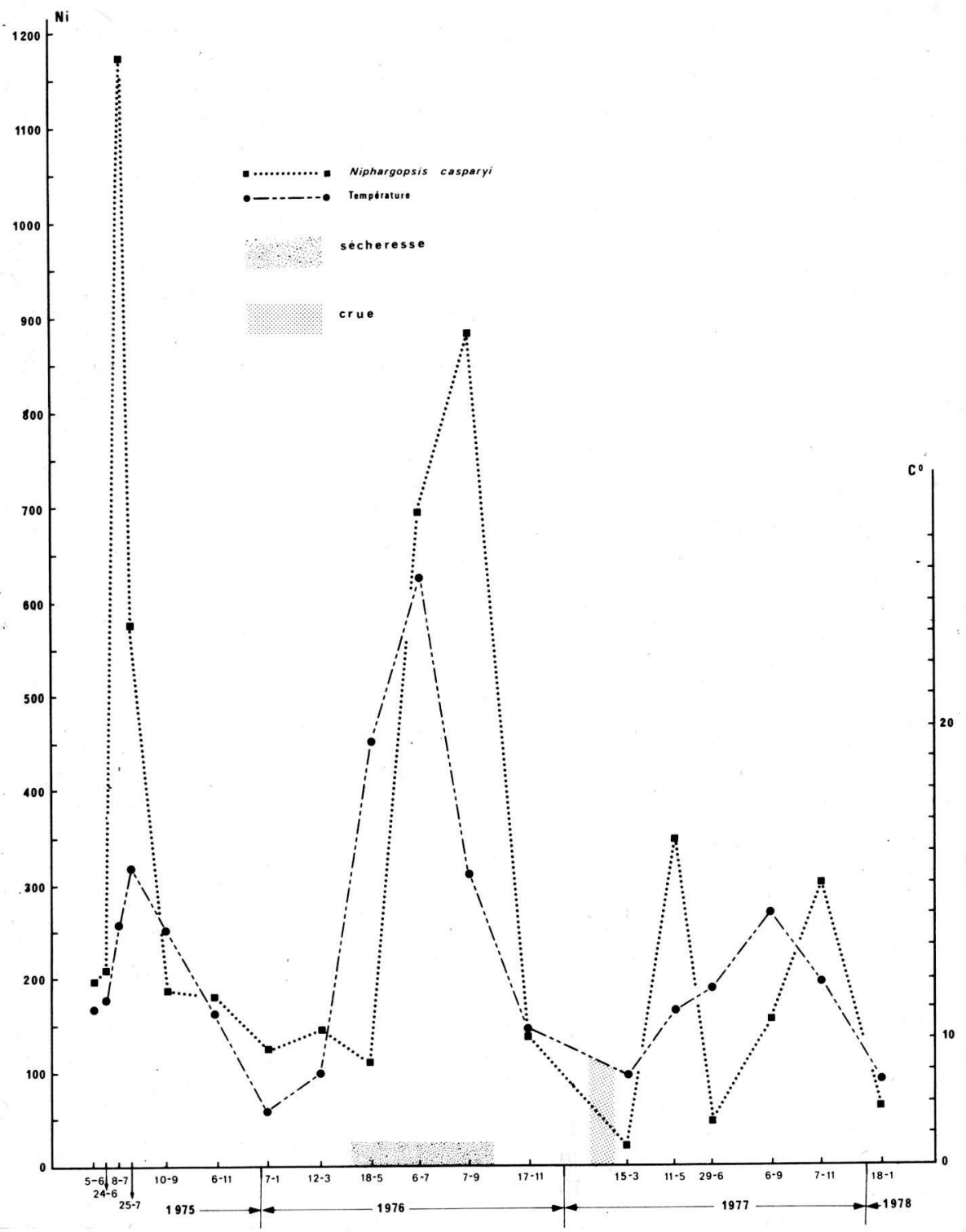

Fig. 3. Evolution de la population de Niphargopsis casparyi, et rappel de la température de l'eau correspondant à chaque prélèvement (station 2).

$\mathrm{Ni}$ : nombre d'individus présents dans un prélèvement de 1001 d'eau. 
ment pour 1001 . d'eau), elle-même liée à un appauvrissement du peuplement global (256 organismes pour 100 1.). Par la suite, deux maximums nettement inférieurs aux précédents, sont observés sur la courbe; l'un au printemps, l'autre en automne: en 1977, la population de Niphargopsis n'a donc pas retrouvé un effectif comparable à celui des deux années précédentes, alors que pendant ce délai les Cyclopoïdes, composés essentiellement de Diacyclops languidoides s.l. et Diacyclops languidus, retrouvent une densité voisine de celle de 1975.

L'effet de la crue a donc été important sur $N$. casparyi.

(b) Espèces épigées de la station 8

Les effectifs de chacun des grands groupes systématiques (fig. 2) augmentent considérablement de 1975 à 1977. sont:

Les organismes épigés principalement responsables de cette évolution

- Polycelis felina (Turbellariés)

- Pisidium sp. (Lamellibranches)

- Isohypsibius sp. (Tardigrades)

- Gammarus pulex (Crust. Amphipodes)

- Asellus aquaticus (Crust. Isopodes)

Les résultats sont représentés sur la figure 4.

Ils montrent l'importante augmentation numérique de ces cinq espèces après la crue de février 77. En revanche, le nombre des Amphipodes troglobies (représentés par 10 espèces) reste stable. Un phénomène semblable s'est produit pour les populations de Nématodes, Oligochètes, Hydracariens, Ostracodes et Cyclopoïdes, qui ont tous augmenté dans les mêmes proportions.

Cet enrichissement global de la station n'a pas totalement modifié le caractère mixte de son peuplement, où se côtoient toujours troglobies et épigés; mais à la fin de 1977, les proportions entre ces deux catégories écologiques sont devenues telles qu'on peut parler d'une très forte "superficialisation" de la communauté installée dans la station 8 . La figure 5, qui représente l'évolution du pourcentage de la biomasse troglobie par rapport à la biomasse totale de la biocénose pendant les trois ans, illustre bien ce fait.

\section{COMMENTAIRES}

Les résultats obtenus par d'autres auteurs sur différents systèmes hydrologiques sont difficilement comparables entre eux. Il existe en effet de nombreuses méthodes de prélèvement (Ronneberger, 1975); de plus, pour une même méthode (pompage), les quantités d'eau prélevées ne sont pas équivalentes: grandes quantités dans le cas présent (100 litres), pompage fractionné de faibles volumes pour DanielopoL (1976) et Gledhill (1977).

En outre, les travaux publiés montrent une diversité considérable des groupes dominants dans les différents biotopes étudiés; par exemple, en abondance relative: 
- les nappes fluviales des alluvions récentes du Tarn (France) renferment un peuplement particulièrement abondant en Amphipodes et en Copépodes (Bou, 1968). La macrofaune est bien représentée par l'Isopode Proasellus slavus dans les sédiments de la rivière yougoslave Drava (Mestrov, 1974; Mestrov et al., 1976).

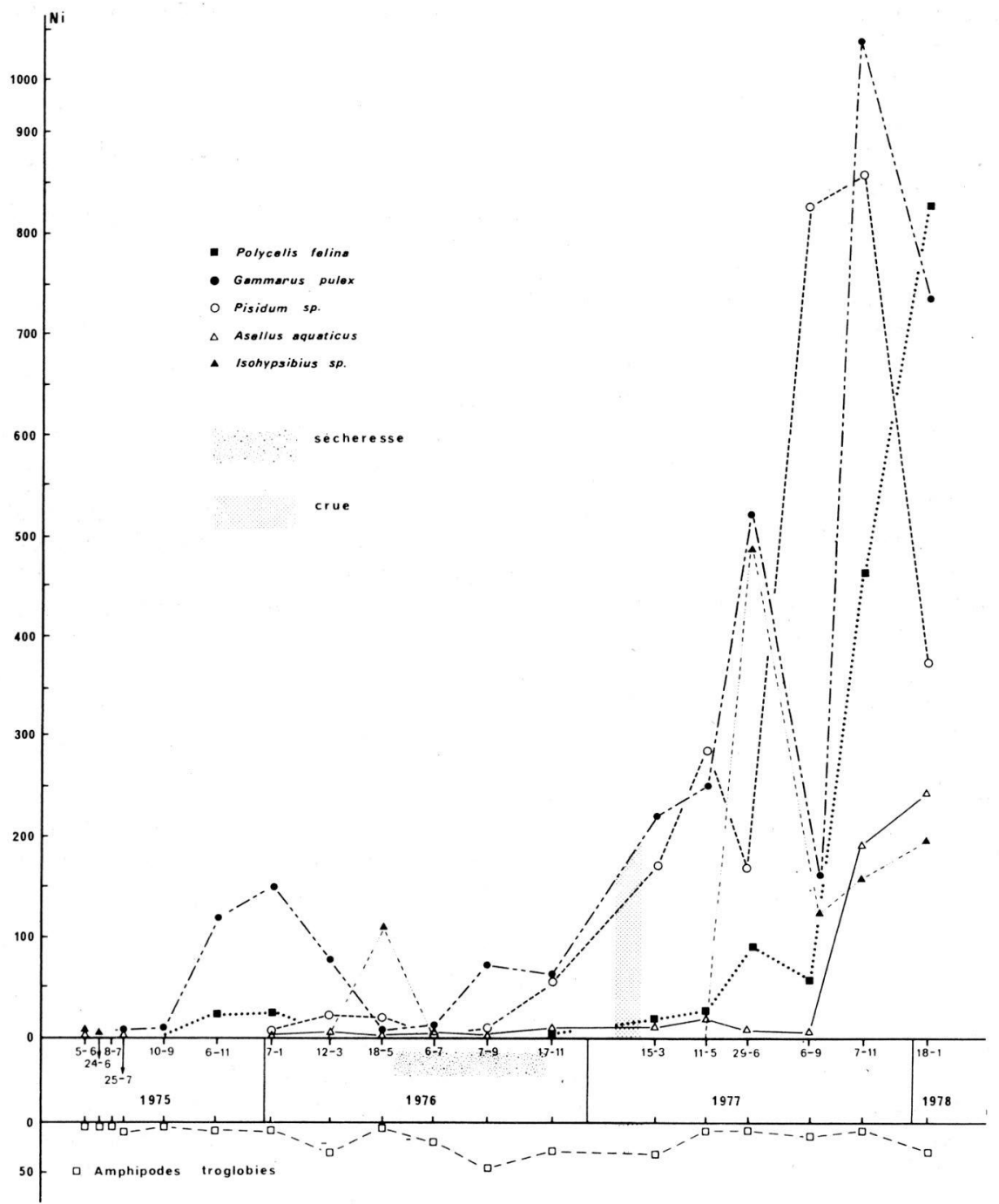

Fig. 4. Evolutions comparées de quelques populations superficielles (en haut), et du groupe des Amphipodes troglobies (en bas), a la station 8.

$\mathrm{Ni}$ : nombre d'individus présents, dans un prélèvement de 1001 d'eau. 
- par contre, les Nématodes, Oligochètes et Cyclopoïdes occupent jusqu'à $80 \%$ de la faune interstitielle du Danube autrichien (Danielopol, 1976), et sont trouvés en grande quantité en Italie dans les alluvions de l'Adige (Ferrarese et Sambugar, 1976). Dans le Breg (affluent allemand du Danube), ce sont cette fois les Harpacticoïdes qui représentent jusqu'à $50 \%$ de la faune totale (Schwoerbel, 1961).

Cependant, l'ensemble des travaux effectués ces dernières années a montré que la plupart des animaux interstitiels se concentrent dans les couches superficielles (40-60 cm de profondeur) de l'eau souterraine (Schwoerbel, 1961; Husmann, 1974, 1976; Danielopol, 1976; Mestrov et al., 1976; Bou, 1968, 1977; Williams et Hynes, 1974). C'est pourquoi nous pensons que la méthode employée ici (pompages de grands volumes dans la zone la plus peuplée), si elle ne nous renseigne pas sur la distribution verticale des organismes dans le sédiment, nous permet une bonne estimation des biocénoses en place.

Nous ne confronterons donc pas longuement nos résultats quantitatifs avec d'autres; ils montrent en effet que, chacune à leur manière, les stations 2 et 8 sont différentes de celles des sédiments alluvionnaires fluviaux déjà connus. Nous énumèrerons simplement les principales informations que les paragraphes précédents ont apportées sur les biocénoses qui y résident.

(a) Considérée globalement sur l'ensemble des prélèvements, la station 2 (dont le pourcentage de troglobies et phréatobies peut être estimé à $50 \%$ en abondance relative et à $80 \%$ en biomasse approchée) apparaît comme nettement plus "hypogée" que la station 8 (où les espèces souterraines représen-

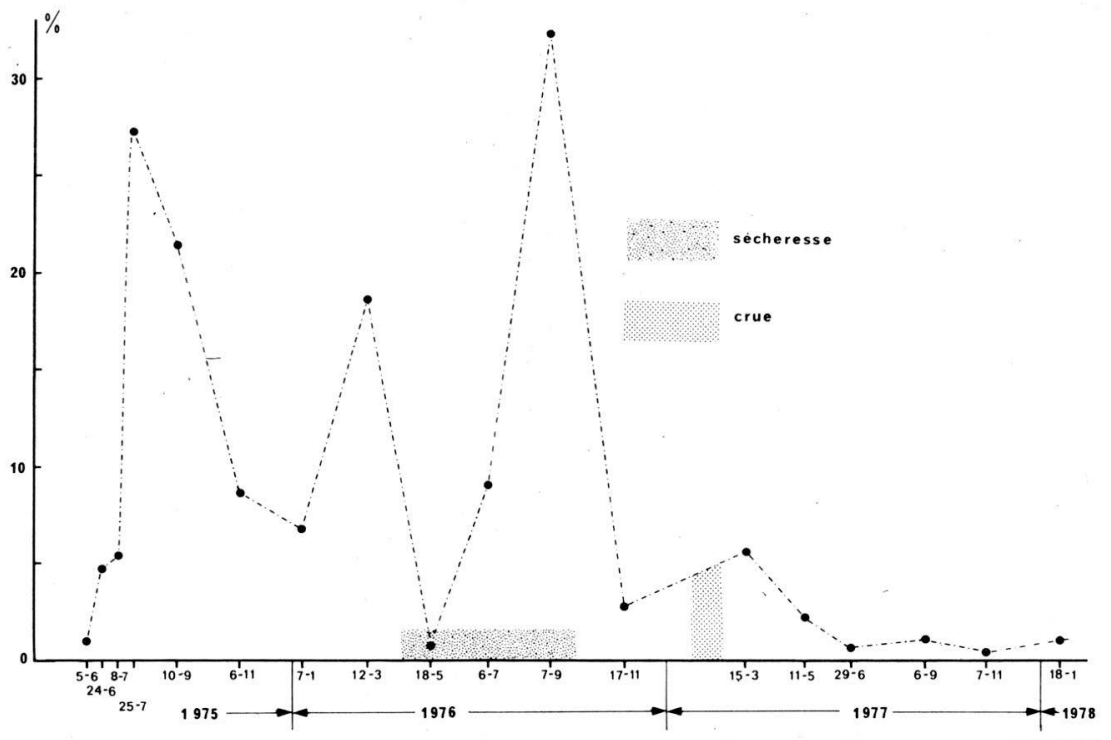

Fig. 5. Estimation du pourcentage de la biomasse des troglobies par rapport à la biomasse totale de la biocénose, pour chaque prélèvement, pendant trois ans (station 8). 
tent $8,2 \%$ en biomasse, et seulement $1 \%$ en abondance relative). Elle est également la plus spécialisée des deux stations, Niphargopsis casparyi étant très fortement dominant dans le peuplement.

(b) la station 8 présente, d'une façon générale, une très forte concentration de populations de type épigé, qui pénètrent jusqu'à au moins un mètre sous la surface du sédiment. Elle apparaît très riche et diversifiée. Les nombres d'individus sont comparables à ceux cités par Williams et Hynes (1974) pour une profondeur voisine. L'importance écologique de cette "couche biologique superficielle souterraine" (Gibert et al., 1977) n'est plus à démontrer, pas plus que son éventuelle vulnérabilité aux agressions du milieu extérieur (Mestrov, 1974; Mestrov et al., 1976; Bou, 1977; Danielopol, 1976).

(c) Les variations quantitatives observées dans les deux peuplements sont en apparente opposition avec les caractéristiques hydrologiques des stations: en station 2 , à un régime très variable étroitement lié à celui du Rhône vif, correspond un peuplement qui a assez peu évolué pendant la durée de notre étude. Dans le même temps, celui de la station 8 , qui semblait devoir être à priori le plus stable (l'eau alimentant cette station est très tamponnée par l'apport considérable de l'aquifère issu de la plaine de La Valbonne), a une croissance de type exponentiel.

(d) Ce phénomène d'explosion démographique, observé depuis le printemps 1977 en station 8, peut être interprété de plusieurs façons différentes:

- Le brusque apport de limon et de matière organique après la grande crue du Rhône est susceptible d'avoir modifié le milieu à un point tel que des organismes épigés, amenés de l'amont, ont pu se maintenir et se multiplier dans le substrat; en même temps, les populations locales ont pu se développer dans un contexte rendu plus favorable, déterminant ainsi ce peuplement très riche dont la stabilité à moyen terme n'est pas assurée. Signalons cependant qu'en mars 1978 (résultats non représentés sur les figures 4 et 5), celui-ci continue d'augmenter. Williams et Hynes (1974), et avant eux Schwoerbel (1961) puis Egglishaw (1964) ont constaté des faits très semblables, Williams et Hynes allant même jusqu'à créer les termes de "occasional and permanent hyporheos."

- A contrario, le pompage régulier à un endroit précis d'une grande quantité d'eau peut avoir déblayé le limon fin et fait naître de nouveaux interstices au sein du sédiment; ils auraient ainsi servi de lieu de refuge ou de concentration pour la faune. Mais, nos prélèvements étant effectués tous les deux mois dans ce courant de rééquilibrage (dont le débit est toujours suffisant pour mettre en suspension dans la lône des sables grossiers), il nous semble que le recolmatage des vides créés artificiellement par le pompage ne devrait pas demander autant de temps. Rappelons, de plus, que rien de comparable n'a été observé en station 2, ni dans d'autres stations dont nous nous occupons actuellement.

- Les courants de rééquilibrage du niveau piézométrique évoluent dans le temps; peut-être celui de la station 8 s'est-il renforcé naturellement, engendrant pour certaines espèces rhéophiles un "ffet de source" (Gammarus pulex, Polycelis felina)? 
Dans l'état actuel de nos connaissances, il semble qu'aucune de ces trois hypothèses ne puisse être écartée a priori.

Les résultats commentés ci-dessus ne concernent qu'une analyse globale des variations observées sur ces populations interstitielles. Par la méthode employée ici, les zonations verticales et les diverses migrations animales ne peuvent être étudiées. L'implantation de substrats artificiels, assez utilisés pour l'échantillonnage du benthos (Roux et al., 1976), sert déjà à des recherches de zonation verticale (Poole et Stewart, 1976); après avoir été adaptée à la granulométrie de nos milieux interstitiels, et après la mise au point d'une technique de tri appropriée, il semble que cette méthode puisse être un test comparatif pour les pompages, et que son emploi constituerait une voie de recherche très positive pour l'avenir.

\section{RÉSUMÉ}

Deux stations phréatiques dont l'eau alimente des bras morts (Lônes) ont été étudiées simultanément pendant trois années consécutives. Les prélèvements (100 litres) ont été effectués à $60 \mathrm{~cm}$ sous la surface du sédiment par la méthode de pompage "BOU-ROUCH."

Les peuplements analysés globalement montrent que les stations abritent des biocénoses très différentes. L'une (Station 2), s'avère assez spécialisée et très nettement hypogée $-80 \%$ de sa biomasse totale est troglobie, et $67 \%$ sont représentés par le seul Amphipode Niphargopsis casparyi - . L'autre (Station 8), est très diversifiëe; ses 8 groupes principaux sont constitués par des organismes superficiels.

Les peuplements ont évolué au cours des trois années de prélèvements. Celui de la station 2 a subi des fluctuations, mais retrouve son effectif initial en 1977. Au contraire, celui de la station 8 accuse une croissance de type "exponentiel" dont les responsables sont ces groupes superficiels, les troglobies restant stables.

\section{OUVRAGES CITÉS}

BOU, C. 1968. Faune souterraine du sud-ouest du Massif-Central. II - Contribution à la connaissance de la faune des eaux souterraines de l'Albigeois. Ann. Spéléol. 3(2):29-31.

BOU, C. 1974. Recherches sur les eaux souterraines - 25 - Les méthodes de récolte dans les eaux souterraines interstitielles. Ann. Spéléol. 29(4):611-619.

BOU, C. 1977. Conséquences écologiques de l'extraction des alluvions récentes dans le cours moyen du Tarn. Bull. Ecol. 8(4):435-444.

BOU, C. et R. ROUCH. 1967. Un nouveau champ de recherches sur la faune aquatique souterraine. C.R. Acad.Sci. Paris 265:369-370.

DANIELOPOL, D.L. 1976. The distribution of the fauna in the interstitial habitats of riverine sediments of the Danube and the Piesting (Austria). Int. J. Speleol. 8:23-51.

EGGLISHAW, H.J. 1964. The distributional relationship between the bottom fauna and plant detritus in streams. J. Anim. Ecol. 33:463-476.

FERRARESE, U. et B. SAMBUGAR. 1976. Ricerche sulla fauna interstiziale iporreica dell'Adige in relazione allo stato di inquinamento del fiume. Rivista di Idrobiologia, $X V, 1: 47-124$.

GIBERT, J., R. GINET, J. MATHIEU, J.L. REYGROBELLET, et A. SEYED-REIHANI. 1977. Structure et fonctionnement des écosystèmes du Haut-Rhône français. IV - le peuplement des eaux phréatiques; premiers résultats. Ann. Limnol. 13 1:83-97.

GLEDHILL, T. 1977. Numerical fluctuations of four species of subterranean amphipods during a five year period. Crustaceana Suppl. 4:144-152.

HUSMANN, S. 1974. Versuche zur Erfassung der vertikalen Verteilung von Organismen und chemischen Substanzen im Grundwasser von Talauen und Terrassen; Methoden und erste Befunde. Int. J. Speleol. 6:271-302. 
HUSMANN, S. 1976. Langsamsandfilter als Lebensraüme von Grundwassertieren, mit Befunden aus Wiesbaden-Schierstein. Wissenschaftliche Berichte über Untersuchungen und Planungen der Stadtwerke Wiesbaden AG, Band 3:83-92.

JUGET, J., C. AMOROS, D. GAMULIN, J.L. REYGROBELLET, M. RICHARDOT, Ph. RICHOUX, et C. ROUX. 1976. Structure et fonctionnement des écosystèmes du HautRhône français. II - Étude hydrologique de quelques bras morts. Premiers résultats. Bull. Ecol. 7(4):479-492.

JUGET, J., B.J. YI, C. ROUX, Ph. RICHOUX, M. RICHARDOT-COULET, J.L. REYGROBELLET, et C. AMOROS. 1979. Structure et fonctionnement des écosystème du Haut-Rhône français. VII - Le complexe hydrographique de la Lône des Pêcheurs (ancien méandre du Rhône). Rev. Suisse Hydrol. 41/2:395-417.

MESTROV, M. 1974. Les données des recherches écologiques et faunistiques des eaux interstitielles le long des rivières Sava et Drava concernant la pollution. 29th Congr. Int. Assoc. Limnol., Canada 1974; abstracts:138.

MESTROV, M., R. LATTINGER-PENKO, et V. TAVCAR. 1976. La dynamique de population de l'Isopode Proasellus slavus ssp.n. et les larves de Chironomides dans l'hyporhéique de la Drave du point de vue de la pollution. Int. J. Speleol. 8:157-166.

POOLE, C., et W. STEWART. 1976. The vertical distribution of macrobenthos within the substratum of the Brazos river, Texas. Hydrobiologia 50 (2):151-160.

RENAUD-DEBYSER, J. 1963. Recherches écologiques sur la faune interstitielle des sables Bassin d'Arcachon, île de Bimini, Bahamas. Vie et Milieu, supplément $n^{\circ}$ 15:157 p.

$\bar{R} \bar{E} \bar{Y} \bar{G} \bar{R} O \bar{B} \bar{B}$ LLLET, J.L., J. MATHIEU, R. GINET, et J. GIBERT. 1981. Structure et fonctionnement des écosystèmes du Haut-Rhône français. VIII - Hydrologie de deux stations phréatiques dont l'eau alimente des bras morts. Int. J. Speleol. (in this volume).

RONNEBERGER, D. 1975. Zur Kenntniss der Grundwasserfauna des Saale-Einzugsgbietes (Thüringen). Limnologica, Berlin 9(3):323-419.

ROUX, A.L., H. TACHET, et M. NEYRON. 1976. Structure et fonctionnement des écosystèmes du Haut-Rhône français. III - Une technique simple et peu onéreuse pour l'étude des macroinvertébrés benthiques des grands fleuves. Bull. Ecol. 7(4):493-496.

SCHWOERBEL, J. 1961. Uber die Lebensbedingungen und die Besiedlung des hyporheischen Lebensraumes. Arch. Hydrobiol. Suppl. 25:182-214.

WILLIAMS, D.D., et N.B. HYNES. 1974. The occurrence of benthos deep in the substratum of a stream. Freshwater Biol. 4:233-256.

\section{LISTE FAUNISTIQUE}

Certaines détermination̨s ont été effectuées par des spécialistes qui ne sont pas les auteurs ou en collaboration avec eux; qu'ils veuillent bien trouver ici l'expression de nos remerciements:

Plathelminthes: E. Pattée, Nématodes et Oligochètes: J. Juget, Mollusques: R. Bernasconi et M. Coulet, Tardigrades: G. Ramazzotti, Cladocères: C. Amoros, Cyclopoïdes: F. Lescher - Moutoué, Harpacticoïdes: R. Rouch, Ostracodes: D. Danielopol, Isopodes: J.P. Henry, Trichoptères: H. Tachet, Coléoptères: P. Richoux.

Sur cette liste, chaque unité systématique, présente dans l'une ou l'autre station, est accompagnée d'une estimation de sa représentation au sein de la biocénose. Celle-ci est exprimée en 4 classes, déterminées à la fois:

- par la constance dans les prélèvements,

- et par l'abondance relative (pondérée par la biomasse approchée)

Ainsi, les unités systématiques rares sont accompagnées d'un petit carré blanc, et les autres d'un carré noir dont la surface est proportionnelle à leur importance dans le peuplement. 
CNIDAIRES

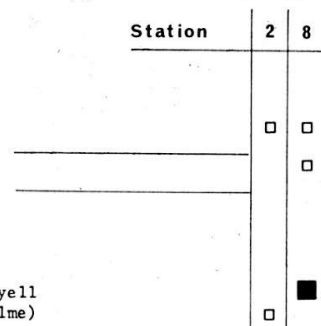

NĚ MATHE LMI NTHES

Hydrozoaires

- Hydridae ind. (1)

GORDIENS ind.

PLATHELMINTHES

Turbellariés

Planariidae

- Polycelis felina Dalyel

- Polycelis felina Dalyell
- g. sp. (anophtalme)

Nématodes (2)

- Plectidae

- Plectus cirratus (Bastian, 1865)

- Plectus rhizophilus (De Man, 1880)

- Monhisteridae

- Theristus setosus (Bütschli)

- Tripylidae

- Tripy la filicaudata

- Trichistoma monohystera

- Tobmilus grandipapiliatus

onchidae

- Mononchus trroncatus Bastian, 1865

- Mononchus papizlatus Bastian, 1865

- Paractinolaimidae

- Paractinolaims sp.

- Dorylaimidae

- Mesodomy Zaimus sp.

- Qudsianematidae

- Eudory laimus sp.

- Aporce laimidae

- Aporce laime llus sp.

- Mermi thidae

- Mermis sp.

- g. sp. ind

ANNÉLIDES

Oligochètes

- Aelosomatidae

- Aelosoma hemprichi Ehrenberg, 1828

- Aelosoma sp.

- Naididae

- Chaetogaster langi Bretscher, 1896

- Chaetogaster diastrophus (Gruithuisen, 1928)

- Amphichaeta leydigii Tauber, 1879

- Specaria josinae (Vejdovsky, 1833)

- Uncinais uncinata (Orsted, 1842)

- Ophidonais serpentina (Müller, 1773)

- Nais commoris Piguet, 1906

- Nais vamabilis Piguet, 1906

- Nais simplex Piguet, 1906

- Nais alpina Sperber, 1948

- Nais barbata Müller, 1773

- Nais pseudobtusa Piguet, 1906

- Nais pardalis Piguet, 1906

- Nais elinguis Müller, 1773

- Slavina appendiculata (D'Udekem, 1855)

- Vjedovskiella intermedia (Bretscher, 1896)

- Stylaria lacustris (Linné, 1767)

- Dero digitata (Müller, 1773)

- Dero obtusa d'Udekem, 1855

- Pristina foreli (Piguet, 1906)

- Pristina idrensis Sperber, 1948

口

(1) Vuel'extrême difficulté de détermination de ce matériel (élevage nécessaire) nous n'avons pas jugé bon de préciser au-delà. Seule, Pelmatohydra oligactis (Pallas) a puêtre identifiée dans 2 stations voisines (Dét. $x$. Kolenkine, Lyon)

(2) Pour les Nématodes, nous ne fournissons qu'une information de présence. Les résultats quantitatifs ne sont Ras connus.

$\rightarrow$ * espècesconsidérées comme phréatobies ou troglobies 
- Tubificidae

- Aulodrilus pluriseta (Piguet, 1906)

- Aulodrilus limnobius Bretscher, 1899

- Tubifex ignotus (Stolc, 1886)

- Psamoryctides barbatus (Grube, 1861)

- Potamothrix heuscheri (Bretscher, 1900)

- Potamothrix vejdovskyi (Hrabe, 1941)

- Limnodrilus hoffmeistemi Claparède, 1862

- Rhyacodrilus coccinaeus (Vejdovsky, 1875)

- Rhyacodrilus sp.

- Lumbriculificidae ind. immatures

- Stylodrilus heringionus Claparède, 1862

- Stylodrilus parvus (Hrabe et Cernosvitov, 1927)

- Trichodrilus leruthi (Hrabe, 1937)

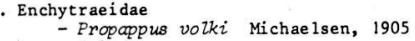

- Achaeta sp.

- Achaeta sp.

(Nielsen et Christensen, 1959)

- Cernosvitoviezla atrata

- Cognettia grandulosa (Michaelsen, 1898)

- Enchytraeus bucholzi Vejdovsky, 1879

- Marionina argentea (Michaelsen, 1899)

- Marionina riparia Bretscher, 1899

- Marionina sp.

- Haplotaxidae

- Haplotaxis gordioides Michaelsen, 1900

Achètes

- Glossiphoniidae

- Glossiphonia complanata (Linné 1758)

MOLLUSQUES

\section{Gastéropodes}

- Cochlostomidae

$$
\text { - Cochlostoma sp. (3) }
$$

- Hydrobiidae

- Hauffenia minuta minuta Draparnaud

- Valloniidae

- Vallonia pulchelza Müller, 1774 (3)

- Pupillidae

- Vertigo sp. "(3)

- Ferussaciidae

- Caecrilioides acioúla, Müller 1774 (3)

- Helicidae

- Helice Zla sp.

- Ellobidae

- Carichium tridentatum Risso, $\$ 826$

- Lymnaeidae

- Radix peregra Müller, 1774

- Planorbidae

- Arriger crista (Linné, 1758)

- Ancylidae

- Acroloxus lacustris (Linné, 1758)

Lame 11 ibranches

- Sphaeridae

- Pisidium sp.

TARDI GRADES

- Isohypsibius sp.

ARTHROPODES

\section{Arachnides}

Acariens

Prostigmates

- Hydracariens ind.

lés os tigmates

- Gamasidae ind. (4)

Oribates ind. (4)
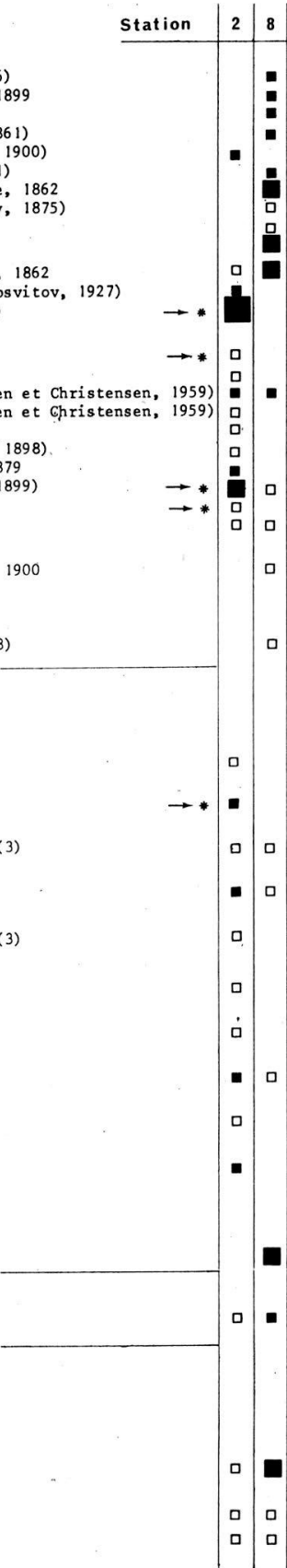

(3) espèces connues comme terrestres

(4) exogènes appartenant à la faune du sol 
Crustacés

Cladocères

- Daphniidae

- Daphnia longispina O.F. Müller, 1785

- Ceriodaphnia reticulata (Jurine, 1820)

- Ceriodaphnia megoss Sars, 1862

- Simocephalus expinosus (Koch, 1841)

- Scapholeberis mucronata (O.F. Múller, 1785)

- Bosminidae

- Bosmina (Bosmina) Zongirostris (0.F. Müller, 1785)

- Bosmina sp.

- Macrothricidae

- Iliocryptus sordidus (Liêvin, 1848)

- Chydoridae

- Evrycercus Zamellatus (0.F. Müller, 1785)

- Acroperus harpae (Baird, 1835)

- Alona guttata Sars, 1862

- Alona affinis (Leydig, 1860)

- Disparalona rostrata. (Koch, 1841)

- Pleuroxus uncinatus Baird, 1850

- Pleuroxus adioncus (Jurine, 1820)

- Chydorus sphaericus (0.F. Müller, 1785)

- Monospilus dispar Sars, 1862

Os tracodes

- Cypridae

- Candona candida (O.F. Müller, 1785)

- Candona aff. Lobipes Hartwig, 1900

- Candona aff. schellenbergi Klie, 1934

- Candona compressa

- Candona aff. Hertzogi Klie, 1934

- Candona sp.

- Pseudocardona sp.

- Cryptocandona sp.

- Cyclocypris ovum (Jurine, 1820)

- Cipria ophtalmica (Jurine, 1820)

- Eucypris aff. serrata (G.w. Müller, 1900)

- Ilyocypris sp.

- Herpe tocypris reptans (Baird, 1835)

- Cypridopsis vidua (0.F. Müller, 1776)

- Potamocypris aff. variegata (Brady et Norman, 1889)

- Potamocupris s.p.

Copépodes

Calanoïdes ind.

Cyclopoïdes

- Cyclopidae

- Macrocyclops albidus (Jurine, 1820)

- Eucyclops serrulatus (Fischer, 1851)

- Eucyciops macruroïdes (Lilljeborg, 1908)

- Tropocyclops prasinus (Fischer, 1860)

- Paracyclops fimbriatus (Fischer, 1853)

- Acanthocyclops (Acanthocyclops) robus tus (G.0. Sars, 1823)

- Acanthocyclops (Acanthocyclops) sensitivus (Graeter et Chappuis, 1914)

- Acanthocyclops (Acanthocyclops) venustus (Norman et Scott, 1906)

- Acanthocyclops (Acanthocyclops) of. troglophilus Lescher-Moutoue $\rightarrow$ *

- Acartinocyclops (Megacyclops) viridis viridis (Jurine, 1820)

- Diacyclops bicuspidatus (Claus, 1857)

- Diacyclops bisetosus (Rehberg, 1880)

- Diacyclops Zangridus (G.0. Sars, 1863)

- Diacyclops Zanguidoïdes clandestinus (Kiefer, 1926)

- Diacyclops languidoïdes putealis (Chappuis, 1928)

- Diacyclops languidoides hypnicola (Gurney)

- Diacyclops languidoïdes s.s.p.

- Graeteriella (Graeteriella) misetigera (Graeter, 1908)

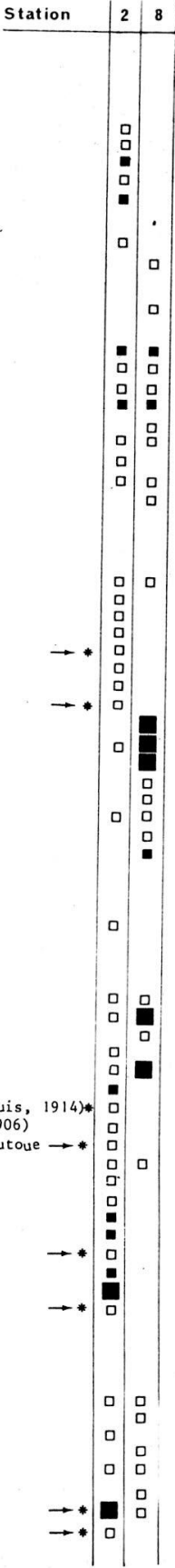

- Canthocamp tidae

- Canthocamptus staphylinus (Jurine, 1820)

- At theyeila (Attheyella) crassa (Sars, 1863)

- Attheyelza (Mrazekiella) wulmeri (De Kerhervé, 1914)

- Bryocamptus (Bryocamptus) minutus (Claus, 1863)

- Bryocamptus (Bmocamptus) zschokkei (Schmeil, 1893)

- Bryocamptus (Limocamptus) echinatus Mrazek, 1893

- Elaphoide zla e laphoides

- Parastenoscaris sp. 
Amphipodes

- Gammaridae

- Gammarus pulex (Linné , 1758)

- Gammarus fossarum Koch, 1836

- Cammarus sp. anophtalme (5)

- Niphargopsis casparyi Pratz, 1932

- Niphargus rhenorhodonensis (Sche

- Niphargus kochianus Bate, 1863

- Niphargus jovanovici Karaman, 1931

- Niphargus sp.

- Niphargus nov. sp. (6)

- Salentinella juberthiae

- Salentine ila de lamarei

- Salentine lla sp.

- Crangony $x$ subterraneus

N. Coineau, 1968

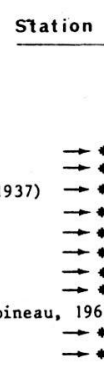

Bate, 1859

\section{Is opodes}

- Asellidae

- Asellus aquaticus Linné

- Proasellus walteri (Chappuis, 1948)

- Microparasellidae

- Microcharon sp.

Insectes

\section{Ap térygotes}

Collemboles (4)

- Sminthuridae

- Dicyrtomidae

- Entomobryidae

- Isotomidae

- Poduridae

(7)

$$
\text { Ptérygotes }
$$

\section{Plécoptères}

- Nemuridae

- Nemura sp. 1. Juv.

- Leuctridae

- Leuctra $o p$. 1. Juv.

Ephëémérogtềres

- Baetidae ind. 1. Juv.

- Caenidae

- Caeris robusta 1. Juv.

- Caenis sp. 1. Juv.

\section{Ir $\underline{\text { ich }}$ honortè res}

\section{- Sericostomatidae}

- Sericos toma sp. L.Juv.

: Goeridae

- Sizosp. 1. Juv.

Coléeortères

- Haliplidae

- Haliplus lineaticollis (Marsham 1802) 1.+ a

- Haliplus rufficollis (De Geer 1775) a.

- Dytiscidae

- Hydroporus sp.

- Dryopidae

- Dryops sp.

- Elmidae

- Esolus parallelepipedus (Müller, 1806) $1 .+$ a .

- Limius volkmari (Panzer, 1793) 1.

\section{Hệtéróptères}

- Corixidae ind. Juv.
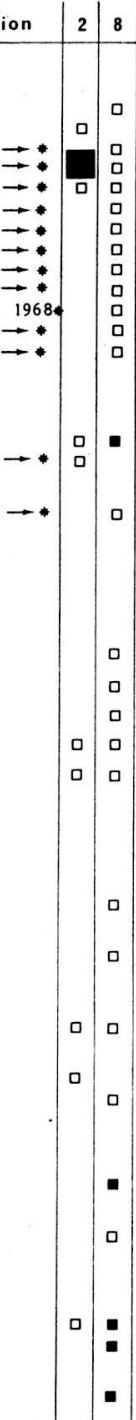

(5) appartiennent au groupe pulex

(6) espèce inconnue en cours d'examen par S. RUFro

(7) 1 . = larves

a. adultes 


\begin{tabular}{|c|c|c|}
\hline Station & 2 & 8 \\
\hline Diptères L. & & \\
\hline $\begin{array}{l}\text { Chi ronomidae } \\
\text { - Chironomiens } \\
\text { - Tanypodinae } \\
\text { - Tany tarsiens } \\
\text { - Orthocladiinae } \\
\text { - Coryneroinae } \\
\text { - Diamesinae } \\
\text { - Juvéni les inde terminés }\end{array}$ & $\begin{array}{l}0 \\
0 \\
0 \\
0\end{array}$ & $\begin{array}{l}\text { a } \\
\text { a } \\
\text { a } \\
\text { a } \\
\text { D }\end{array}$ \\
\hline Ceratopogonidae (type Bezzia) & & - \\
\hline Simulidae & & - \\
\hline Tabani dae & 0 & \\
\hline Autres diptères ind. & & 口 \\
\hline Psogcoptèreses (1). & 0 & \\
\hline
\end{tabular}




\title{
Investigation of the Mutual Influence between a Polluted River and its Hyporheic
}

\author{
Milan Meŝtrov \\ and Romana Lattinger-Penko*
}

\begin{abstract}
SUMMARY
This paper describes investigations of fundamental biological and pratical importance. Interstitial subterranean water (hyporheic) which is near a polluted river in a plain is the subject of the study. The water is becoming increasingly important as a source of drinking water. The relation of the hyporheic water to the physical, chemical, bacteriological and faunistic characteristics of the river is discussed.
\end{abstract}

\section{INTRODUCTION}

The object of this paper is to present our studies on interstitial subterranean waters, those filling tiny crevices among particles of stream bottoms and beaches as well as sand and gravel alluvial sediments of river valleys, i.e. potamostygal, mixopotamostygal, and eustygal (Husmann, 1975).

The phenomenon of life and its features, along with the increasing importance of interstitial subterranean waters as a source of drinking water, involve biological and ecological studies as well as hydrogeological, chemical, physical, and medical ones.

Quantity, physico-chemical characteristics, and distribution of these subterranean waters are relatively well known on both a regional and world scope. Although still in the initial stages, research on the dynamics of composite ecological processes are progressing. Research on natural habitats has scientific as well as practical values, and some experiments have already been performed (Husmann, 1968, 1971, 1974/75; Ritterbusch; 1976).

Ecological research on interstitial waters includes questions concerning: the composition of the biocenosis and the relation of its terrestrial and subterranean faunistic elements; the relations between the structure of biocenoses and the physical features of substratum, e.g., volumes of intergranular spaces and their practicability for water circulation, water temperature and $\mathrm{pH}$; and the relation between biocenoses, water chemistry and the quantity of existing food (Lüpkes, 1976; Husmann, 1968). Studies of vertical and horizontal distributions and density of populations depending on ecological and

\footnotetext{
* Department of Zoology, Faculty of Natural Sciences and Mathematics, University of Zagreb.
} 
other factors have also been carried out (Husmann, 1974/75; Danielopol, 1976; Mestrov, et al., 1976a).

The attachment of certain subterraneán organisms (stygobionts), i.e., of their communities to the biotopes of specific characteristics, also serves as an indicator of the quality of underground waters for human consumption (Husmann, 1964; Spangenberg, 1973).

Since phreatic waters serve as drinking water, understanding of the connections and mutual influences of surface waters (particularly polluted ones) to subterranean waters is of special significance as allochthonous environmental pollution develops. For this purpose various indicators have been used, such as fluorescent tracers (Giammona, 1973) and radioactive tracers (Kubelka, personal communication). Control of changing physico-chemical and biological parameters through a system of permanent bores (Husmann, 1974/75), or provisional ones, are also used (Bou and Rouch's method).

The results presented here were obtained in studies completed during 1973 and 1974 in the Sava river valley, not far from Zagreb (the Jankomir bridge), where the relatively shallow and fast moving river circulates over thick alluvial sediments of sand and gravel watered by phreatic flows.

The aim of our studies was to learn the condition, quality, connections, and mutual influence of the river and surrounding subterranean hyporheic waters (potamostygal and mixo-potamostygal) with the phreatic water (eustygal) in this contact zone, as well as possible infiltration of surface water into the phreatic, and viceversa.

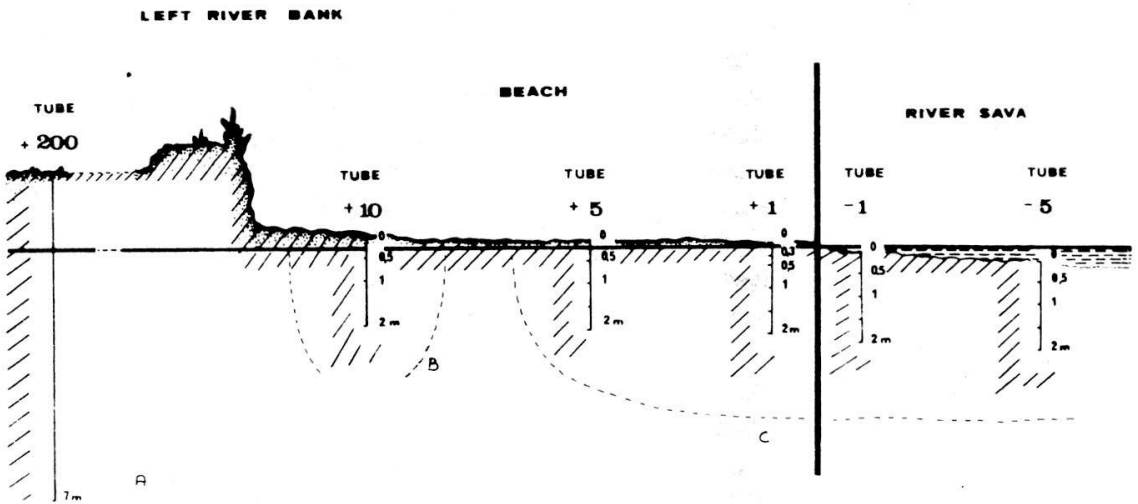

Fig. 1. The river Sava near Zagreb (Jankomir bridge), showing the position of pumping tubes, i.e., sampling points. Numbers indicate their depths and distances from the river edge in meters. 


\section{METHODS}

Samples were taken on 29 June, 17 July, and 3 November 1973, and 17 April 1974 during low water using the Bou-Rouch method. They came from various depths $(0,3-2 \mathrm{~m})$ of crosswise profile including a portion of the left river bank, the beach, and the river bottom (Fig. 1) A Norton pump driven to $7 \mathrm{~m}$ was employed at the same profile, $200 \mathrm{~m}$ from the river.

Determinations of certain bacteriological and chemical parameters of the river water were made, as well as evaluation of the saprobiological conditions of the river and bacteriological, chemical, and faunistic analyses of the interstitial samples. Bacteriological analyses were carried out only in autumn, and more extensive chemical analyses in autumn and spring. All samples taken in 1973 were used for faunistic determinations.

\section{RESULTS, DISCUSSION, AND CONCLUSIONS}

Studies of various relations between the biotopes of subterranean and surface waters were undertaken at a relatively small locality in the Sava river valley near Zagreb. They were carried out on the beach and in the river bottom to $2 \mathrm{~m}$ depth. This was the maximum depth possible with current equipment. At the riverside, samples of water were taken from a depth of $7 \mathrm{~m}$ by a permanently fixed pump, i.e., slightly deeper than the level of subterranean water. The studies included a part of the river bottom and the whole beach of sand and gravel sediments which at high water forms part of a waterside bottom and at low water is exposed. The studies of subterranean water $200 \mathrm{~m}$ away from the river margin were made only once. Accordingly, all areas which, in a vertical and horizontal sense, could be watered by the river were included in the research.

The greater part of the beach closer to the river margin rises so gently that even a slight rise in water level is followed by inflow and affects the substratum. There is more intensive deposition of transported material in this area than in a constantly submerged river bottom, due to a frequent and slow inflow and outflow of river water. This is also indicated by quantities of suspended material at all depths of measurements (Fig. 2).

Comparison of chemical and physical parameters measured simultaneously in the river and interstitial water showed several different ecological areas:

(1) The most distant point from the river $(200 \mathrm{~m})$, where the water is on a depth of $7 \mathrm{~m}$ is situated in an area distinct both in space and some parameters. This location is remarkable for its deficiency of oxygen as well as low temperature. The quantity of $\mathrm{CO}_{2}$ is also considerably less than at ather bores. Alkalinity of 4,1 mval per litre is the lowest recorded in spring, and quantity of ammonia about 10 to 290 times less than in the interstitial water of the beach. This is the phreatic or eustygal area, which differs considerably by its characteristics from others and in which a direct impact of the river could not be defined during the studies (Tab. 1). 
Table 1. Physico-chemical analysis of water from point $+200(7 \mathrm{~m} \mathrm{depth}, 200 \mathrm{~m}$ distance from the river margin).

Water temperature

Dissolved oxygen

Deficiency of oxygen

$\mathrm{BOD}_{2}$

Permanganate number

$\left(\mathrm{KMnO}_{4}\right.$ consumption)

$8,5^{\circ} \mathrm{C}$

Free carbon dioxide

$\mathrm{pH}$

Alkalinity

Chlorides $\mathrm{Cl}$

Ammonia N

$0,8 \mathrm{mg} / 1$

$10,9 \mathrm{mg} / 1$

$4,0 \mathrm{mg} / 1$

$57,1 \%$

Nitrites $\mathrm{NO}_{2}$

$7,9 \mathrm{mg} / 1$

Nitrates $\mathrm{NO}_{3}$

$7,9 \mathrm{mg} / 1$

7,7

Anionic surface-active

agents ("surfactants") TBS

$4,1 \mathrm{mval} / 1$

$14,5 \mathrm{mg} / 1$

$0,01 \mathrm{mg} / 1$

$0,03 \mathrm{mg} / 1$

$0,5 \mathrm{mg} / 1$

$0,0 \mathrm{mg} / 1$

(2) The zone along the water edge, which extends some $5 \mathrm{~m}$ on the beach as well as on the river bottom, is different from the surrounding area. The extent and changes, both in space and time, of physico-chemical and other parameters suggest the existence of various layers. Namely, some parameters at various depths $(0,5,1$ and $2 \mathrm{~m})$ at the same point of measurement, show considerable differences in amount, but a regular increase in these values at each depth in direction from the river edge inland or the reverse is also notable. In addition, seasonal inversions in quantity of oxygen in summer and autumn in a layer at $2 \mathrm{~m}$ depth show that the horizons in consideration have presumably diverse physical structures (granularity). Some indicators, such as more intensive bacteriological activities (heterotrophic bacteria), coliform bacteria, quantity of anionic surface-active agents, presence of populations of the species indicative of a higher degree of organic pollution such as Sphaerotilus natans etc., and the presence of river fauna, demonstrate that the hyporheic zone along the river margin down to $1 \mathrm{~m}$ depth is more influenced by river water and its polluting effect than deeper and more distant zones (Fig. 3, 4, 5, 6; Tab. 2, 3, 4).

(3) Some features of the part of the beach more distant from the river margin (point +10 ) differentiate this zone from the eustygal and from a wider area near the river margin; and various values of the parameters of point +10 and other points closer to the river suggest its characteristic features. Here the quantity of oxygen varies slightly by depth. There are more organic materials here than elsewhere in the alluvium as well as products of mineralization of these organic materials. Perhaps many organic materials and chlorides originate from the surrounding meadows and agricultural areas, and presumably only high water causes a more intensive contact between the river water and the subterranean water of the alluvium. 


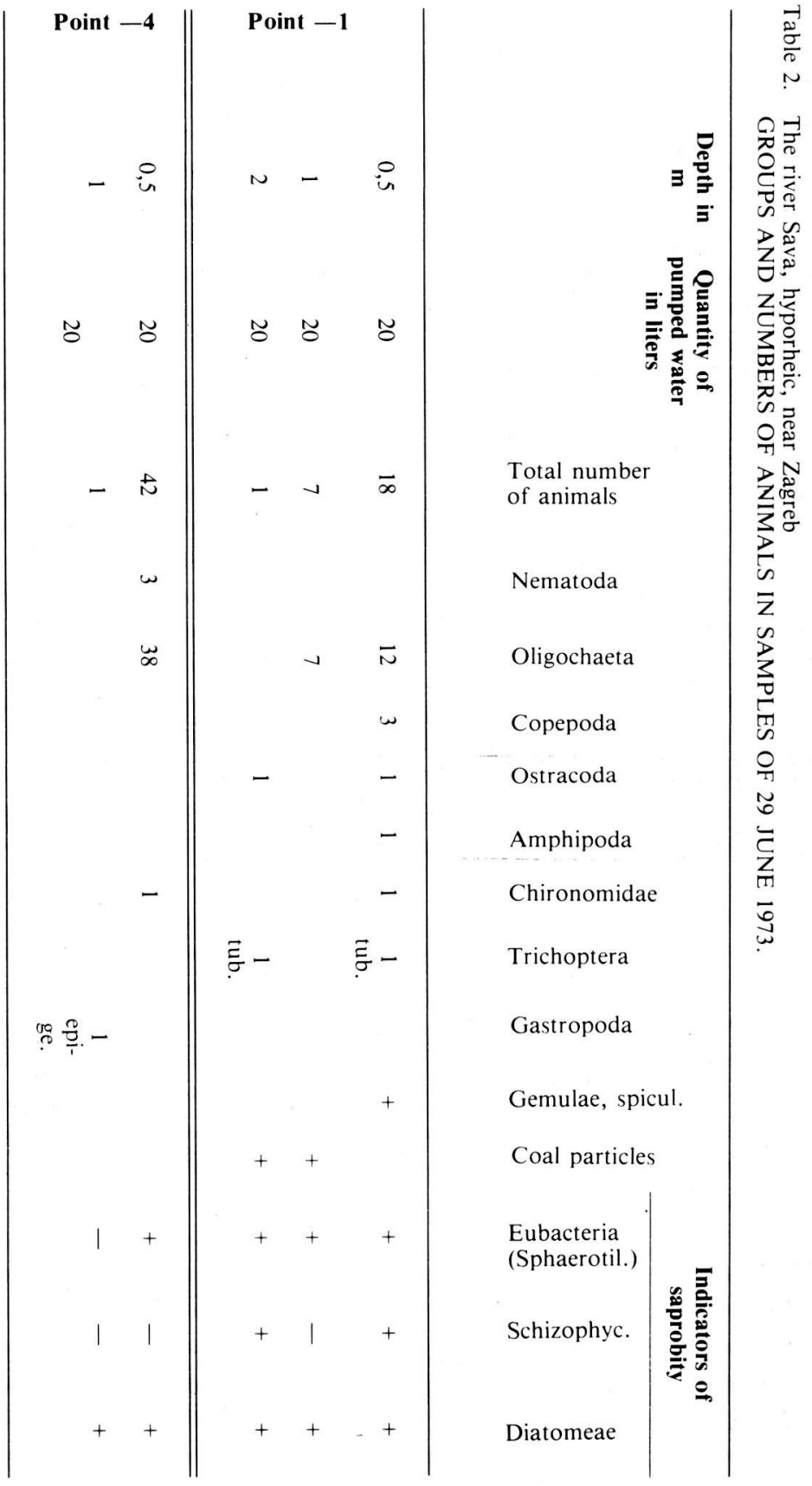


Indicators of pollution like organic compounds, chlorides, nitrates, nitrites, ammonia, and coliform bacteria show that all points on the beach and on the river bottom are subject to the influence of polluted river water at least down to the $2 \mathrm{~m}$ depth. This is confirmed by the presence of particles of coal, Sphaerotilus, and other indicators of saprobity in the deepest examined horizon (Fig. 5, 7, 8, 9, 10, 11; Tab. 2, 3).

The activity of bacteria, evidenced by the presence of products of organic material decomposition and BOD, suggests that the process of autopurification is also performed in the hyporheic. Due to the oxygen demand, down to $1 \mathrm{~m}$ depth, the deficiency of oxygen approaches $99 \%$. In deeper layers, in summer, oxygen almost disappears (Fig. 12).

In comparison with the physically similar habitat by the river Drava near Legrad, studied in the same year (Meŝtrov, et al., 1976a), the fauna of the Sava's hyporheic is not as rich, in the quantitative and qualitative sense (Tab. 4, Fig. 13). Typical subterranean species of Acarina, Isopoda, and Amphipoda

Table 3. The river Sava, hyporheic, near Zagreb GROUPS AND NUMBERS OF ANIMALS IN SAMPLES OF 17 JULY 1973.

\begin{tabular}{|c|c|c|c|c|c|c|c|c|c|c|c|}
\hline & $\begin{array}{c}\text { Depth } \\
\text { in } \\
\text { m }\end{array}$ & $\begin{array}{c}\text { Quantity } \\
\text { of } \\
\text { pumped } \\
\text { water } \\
\text { in } \\
\text { liters }\end{array}$ & 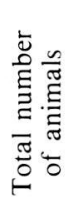 & 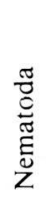 & 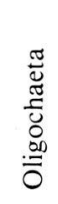 & $\begin{array}{l}\frac{\pi}{0} \\
0 \\
00 \\
00 \\
0\end{array}$ & 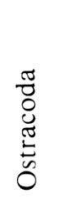 & 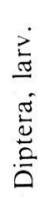 & 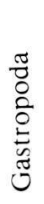 & 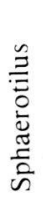 & 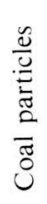 \\
\hline \multirow{3}{*}{$\begin{array}{l}\overline{+} \\
\stackrel{\Xi}{0}\end{array}$} & 0,5 & 40 & 64 & & 61 & 1 & 1 & & 1 & & \\
\hline & 1 & 40 & 7 & 1 & 5 & & 1 & & & & \\
\hline & 2 & 40 & 2 & 1 & 1 & & $\begin{array}{l}3 \times \\
1 / 2\end{array}$ & & & + & + \\
\hline \multirow{3}{*}{ 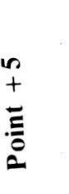 } & 0,5 & 40 & 18 & 1 & 17 & & & & & & \\
\hline & 1. & 40 & 8 & 2 & 2 & & $1 / 2$ & & 4 & & \\
\hline & 2 & 40 & 1 & & 1 & & $\begin{array}{l}3 \times \\
1 / 2\end{array}$ & & & & \\
\hline $\bar{E}$ & 0,5 & 40 & 218 & 3 & 215 & & $\begin{array}{l}5 \times \\
1 / 2\end{array}$ & 1 & & & \\
\hline
\end{tabular}


Table 4. The river Sava, hyporheic, near Zagreb

GROUPS AND NUMBERS OF ANIM-ALS IN SAMPLES OF 3 NOV. 1973.

\begin{tabular}{|c|c|c|c|c|c|c|c|c|c|c|}
\hline & $\begin{array}{l}\text { Depth } \\
\text { in } \\
\text { m }\end{array}$ & $\begin{array}{l}\text { Quantity } \\
\text { of } \\
\text { pumped } \\
\text { water in } \\
\text { liters }\end{array}$ & 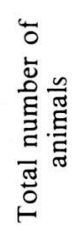 & $\begin{array}{l}\frac{\pi}{0} \\
\stackrel{0}{0} \\
\text { Ẽ } \\
Z\end{array}$ & 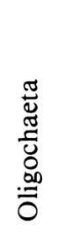 & 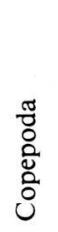 & 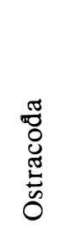 & $\begin{array}{l}\frac{\pi}{0} \\
\frac{0}{Z} \\
\frac{2}{0} \\
\frac{1}{\alpha}\end{array}$ & 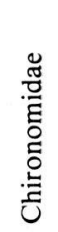 & 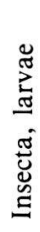 \\
\hline \multirow{4}{*}{$\begin{array}{l}\overline{+} \\
\bar{E} \\
\dot{E}\end{array}$} & 0,3 & 10 & 24 & & 11 & 3 & 1 & & 5 & 4 \\
\hline & 0,5 & 40 & 10 & & 6 & 1 & & & 3 & \\
\hline & 1 & 20 . & 6 & & 4 & 1 & 1 & & & \\
\hline & 2 & 20 & 0 & & & & & & & \\
\hline \multirow{3}{*}{$\begin{array}{l}n \\
+ \\
\pm \\
0 \\
0\end{array}$} & 0,5 & 40 & 6 & & & 5 & & & 1 & \\
\hline & 1 & 20 & 4 & & & & & 1 & 3 & \\
\hline & 2 & 10 & 1 & 1 & & & & & & \\
\hline \multirow{2}{*}{ 音是 } & 1 & 40 & 15 & & 12 & 1 & 1 & & 1 & \\
\hline & 2 & 5 & & & & & $\begin{array}{l}2 \times \\
1 / 2\end{array}$ & & & \\
\hline \multirow{3}{*}{$\frac{T}{0}$} & 0,5 & 40 & 10 & & 2 & & & & 8 & \\
\hline & 1 & 40 & 2 & & 1 & 1 & & & & \\
\hline & 2 & 20 & & & & & $1 / 2$ & & & \\
\hline \multirow{2}{*}{ 를 } & 0,5 & 40 & 6 & & 3 & 2 & & & 1 & \\
\hline & 1 & 40 & 1 & & 1 & & $\begin{array}{l}2 \times \\
1 / 2\end{array}$ & & & \\
\hline
\end{tabular}


are lacking here, which otherwise live in phreatic waters of the Sava valley (Meŝtrov, 1960) and in the hyporheic of the Drava. Perhaps macrocenobionts have a certain role in maintaining the "cleanness" and perviousness of interstices, i.e., circulation of water through them. Eating the infiltrated detritus, they accelerate the process of decomposition and development of a balance in ionic and organic composition of water and open the crevices closed by this detritus (Husmann, 1974, 1975; Bojĉenko, 1975).

Autumnal oxygen enrichment of the deep hyporheic layer of water was not followed by a greater density or a changing composition of stygobiont animal populations. The layers below $1 \mathrm{~m}$ depth in locality studied of the Sava seem to be "ecologically devastated" (Husmann, 1974/75). It is certain that the chronically high degree of pollution with organic and toxic materials causes this phenomenon (Meŝtrov, et al., $1976 \mathrm{~b}, \mathrm{c}$ ). The results of our studies confirm this.

The continuation of comparative ecological research and studies of deeper layers will provide more information and explanations.

Table 5. GROUPS OF ANIMALS SAMPLED IN THE HYPORHEIC OF THE RIVER SAVA near Zagreb and DRAVA near the villages D.Dubrava and Legrad.

\begin{tabular}{|c|c|c|c|}
\hline GROUPS & SAVA & \multicolumn{2}{|c|}{$\begin{array}{c}\text { DRAVA } \\
\text { D. Dubrava Legrad }\end{array}$} \\
\hline Nematoda & + & + & + \\
\hline Oligochaeta & + & + & + \\
\hline Copepoda & + & + & + \\
\hline Ostracoda & + & + & + \\
\hline Amphipoda & $\stackrel{+}{+}$ & - & + \\
\hline Chironomidae & + & + & + \\
\hline Trichoptera & $\stackrel{+}{\text { tub. }}$ & - & - \\
\hline Insecta, others & + & + & + \\
\hline Gastropoda & + & - & + \\
\hline (Sphaerotilus) & + & - & - \\
\hline Ciliata (colon.) & - & - & + \\
\hline Hydrozoa & - & + & + \\
\hline Acarina & - & - & + \\
\hline Isopoda & - & - & + \\
\hline Collembola & - & - & + \\
\hline Coleoptera & - & - & + \\
\hline $\begin{array}{l}\text { Average of animals } \\
\text { per liter }\end{array}$ & 0,63 & 1,3 & 2,2 \\
\hline $\begin{array}{l}\text { Degree of } \\
\text { saprobity }\end{array}$ & $\alpha-\mathrm{m}$ & $\beta-\mathrm{m}$ & $x-m$ \\
\hline
\end{tabular}




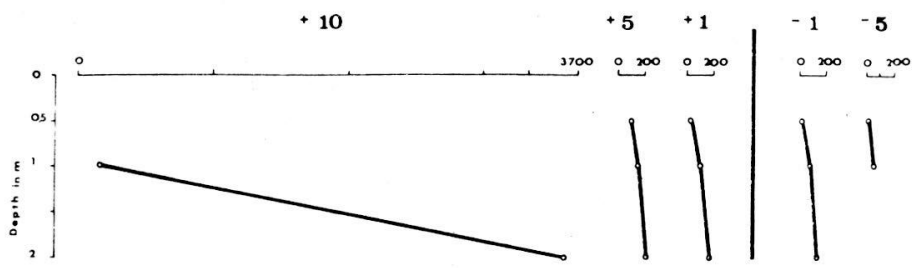

Fig. 2. Suspended matter in hyporheic water (as $\mathrm{mg} / 1$ of residue on evaporation).

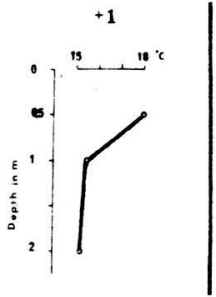

4. 2ง.
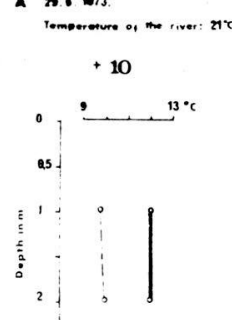

c $\quad-311973$

Fig. 3. Temperature of hyporheic water.

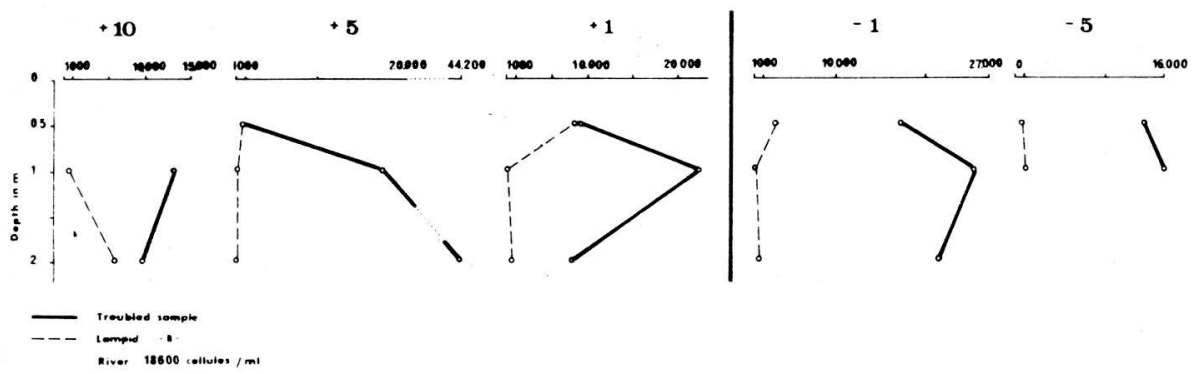

Fig. 4. Number of heterotrophic bacteria in $1 \mathrm{ml}$ of hyporheic water. 


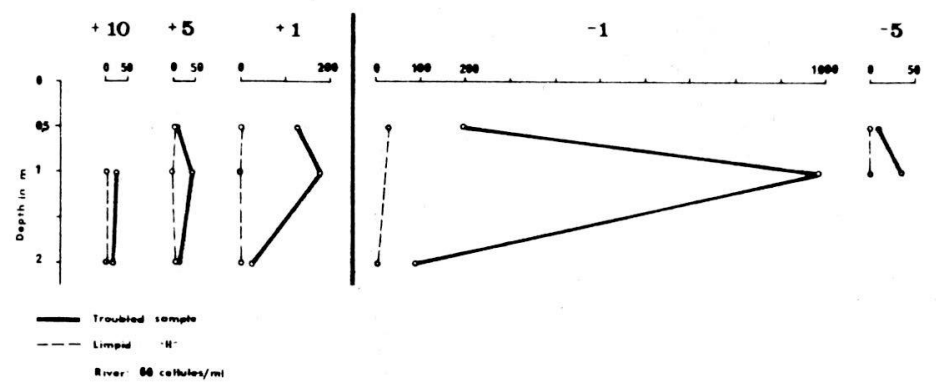

Fig. 5. Number of Escherichia coli cells in $1 \mathrm{ml}$ of hyporheic water.

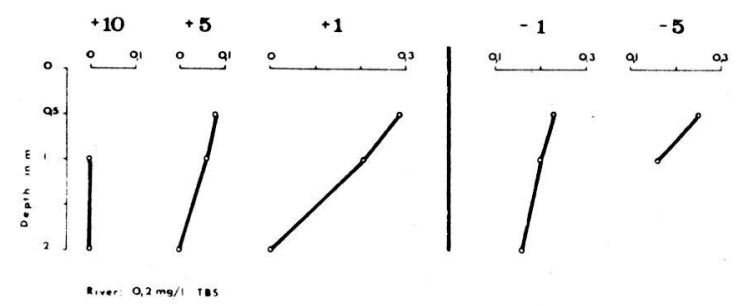

Fig. 6. Anionic surface-active agents ("Surfactants") as mg/1 TBS in hyporheic water.
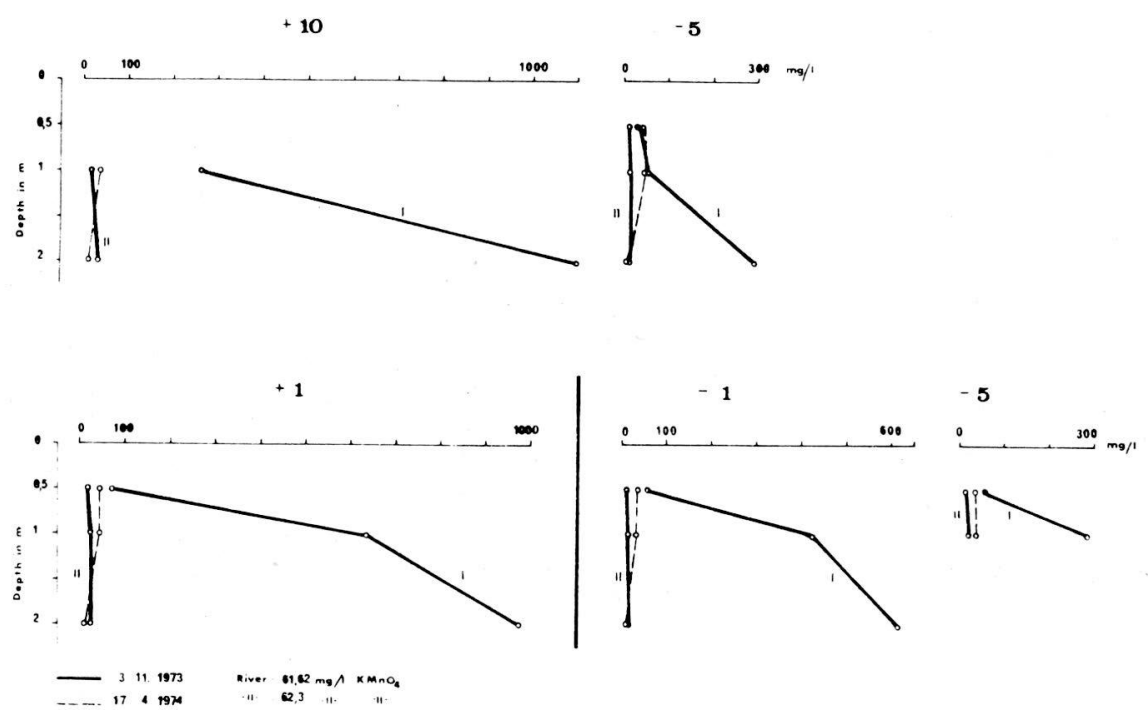

Fig. 7. Permanganate number or $\mathrm{KKnO}_{4}$ consumption, in $\mathrm{mg} / 1$. 


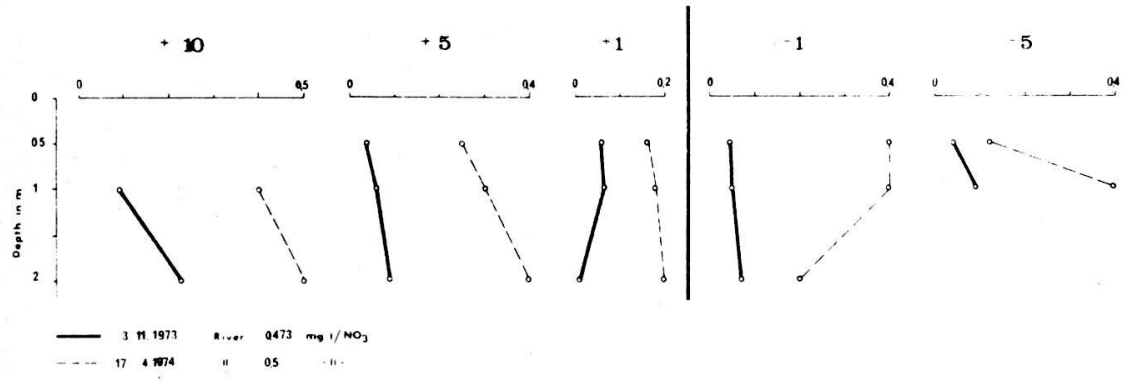

Fig. 8. Nitrates in hyporheic water, as $\mathrm{mg} / 1 \mathrm{NO}_{3}$.

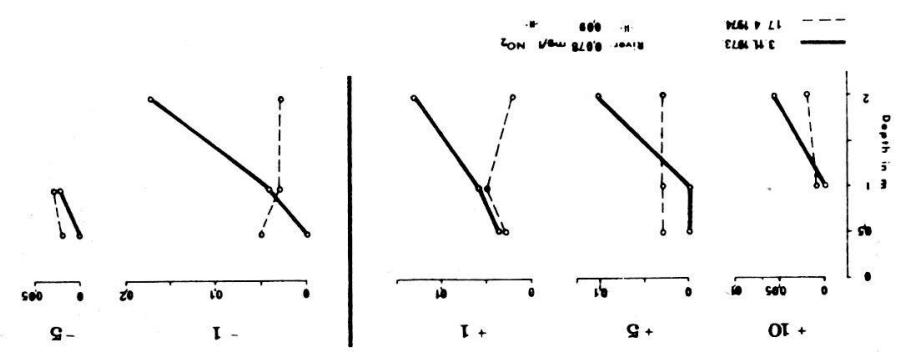

Fig. 9. Nitrites in hyporheic water, as $\mathrm{mg} / 1 \mathrm{NO}_{2}$.

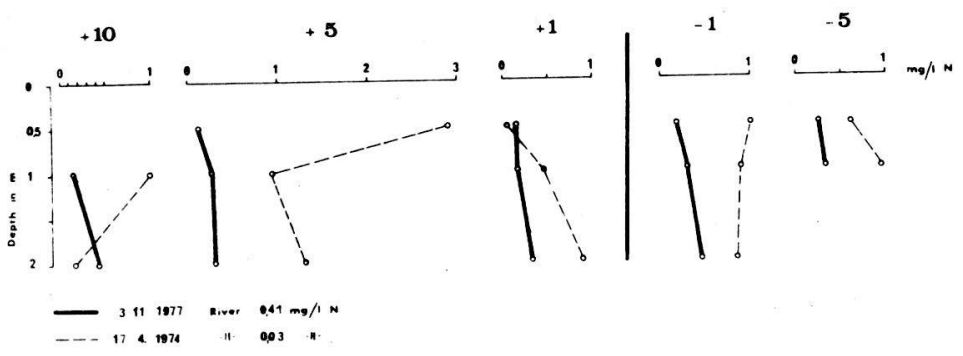

Fig. 10. Ammonia in hyporheic water as $\mathrm{mg} / 1$ ammonia $\mathrm{N}$. 


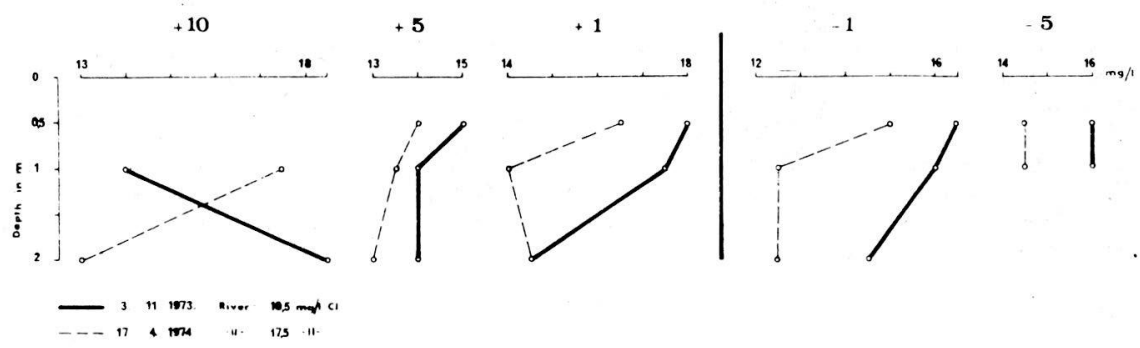

Fig. 11. Chlorides in hyporheic water as $\mathrm{mg} / 1 \mathrm{Cl}$.

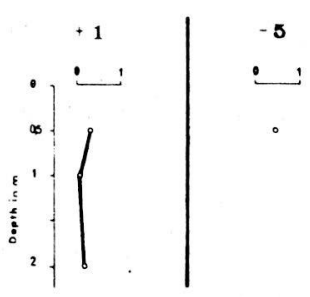

A. 29.1973
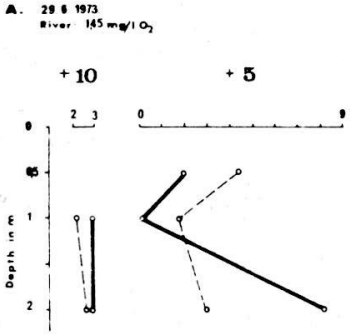

c $\quad 3.111973$ niver $4 \mathrm{mg} / \mathrm{l} \mathrm{O}_{2}$

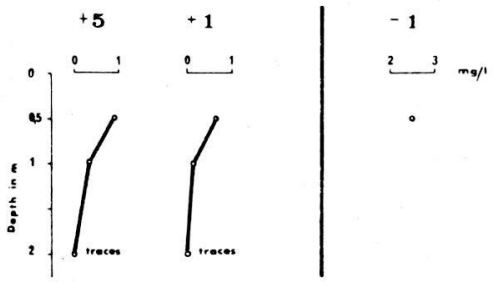

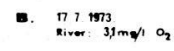

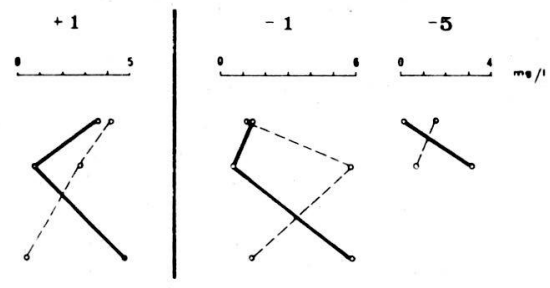

Fig. 12. Quantity of dissolved oxygen in hyporheic water, in $\mathrm{mg} / 1$.

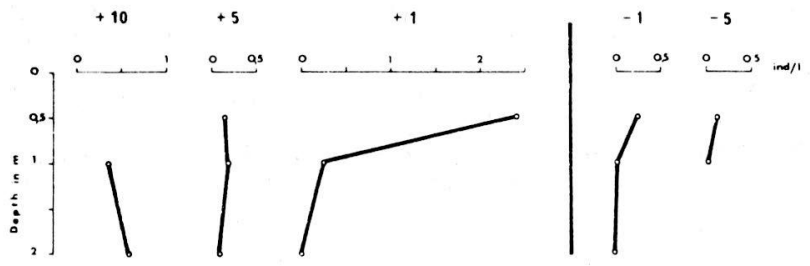

Fig. 13. Number of animals in 1 liter of pumped hyporheic water. 


\section{RÉSUMÉ}

Des recherches présentant à la fois un intérêt fondamental et une importance pratique ont été effectuées sur les eaux souterraines interstielles (hyporhéique) s'écoulant le long de la vallée alluviale d'une rivière polluée: la Save.

En comparant les propriétés physiques, chimiques, bactériologiques, saprobiologiques, de même que les faunes de la rivière de surface et de son écoulement hyporhéique, à des saisons différentes, on peut rechercher quelle est leur influence mutuelle. Les résultats obtenus montrent que l'influence de la pollution de l'eau de la rivière sur l'eau hyporhéique de son lit se fait sentir jusqu'à une profondeur minimale de deux mètres.

\section{REFERENCES}

BOJĈENKO, M.M. 1975. O formirovanii kacestva vodi gidrobiontami. Nauc.dokl.viss.skoli Biol.n., 4,74-77.

DANIELOPOL, D.L. 1976. The distribution of the fauna in the interstitial habitats of riverine sediments of the Danube and the Piesting (Austria) Int.J.Speleol. 8,23-51.

GIAMMONA, Ch.P. 1973. Fluorescent Dye Determination of Groundwater Movement and Contamination in Permeable Rock Strata.Int.J.Speleol. 5,201-208.

HUSMANN, S. 1964. Morphologische, ökologische und verbreitungsgeschichtliche studien über die Bathynellen (Crustacea, Syncyrida) des Niederrhein-Grundwasserstromes bei Krefeld. Gewässer und Abwässer 37/38,46-76.

HUSMANN, S. 1968. Langsamfilter als Biotopmodelle der experimentalökologischen Grundwasserforschung. Gewässer und Abwässer 46,20-49.

HUSMANN, S. 1971. Die gegenseitige Ergänzung theoretischer und angewandter GrundwasserLimnologie; mit Ergebnissen aus Wasserwerken Wiesbadens. Die Sicherstellung der Trinkwassersorgung Wiesbadens. Stadtwerke Wiesbadens AG.

HUSMANN, S. 1974. Die ökologische Bedeutung der Mehrzellerfauna bei der natürlichen und künstlichen Sandfiltration. Künstliche Grundwasseranreicherung am Rhein. Wissenschaftliche Berichte über Untersuchungen u. Planungen der Stadtwerke Wiesbaden AG, 2,173-183.

HUSMANN, S. 1974/75. Versuche zur Erfassung der vertikalen Verteilung von Organismen und chemichen Substanzen im Grundwasser von Talauen und Terrasen; Methoden und erste Befunde. Int.J.Speleol. 6,271-302.

HUSMANN, S. 1975. Die Schotterufer des Niederrheins bei Krefeld:abwasserkranke Biotope mit gestörter Uferfiltration. Gewässer und Abwässer 57/58,7-26.

LÜPKES, G. 1976. Die vertikale Verteilung von Ciliaten im Stygorhithral der Fulda (Beitrag zur Kenntnis mesopsammaler Ciliaten in Fliessgewässern). Int.J.Speleol. 8,127-133.

MEŜTROV, M. 1960. Faunistiĉko-ekoloŝka i biocenoloŝka istraẑivanja podzemnih voda savske nizine.Biol.glasnik 13,73-109.

MESTTROV, M., R. LATTINGER-PENKO, and V. TAVĈAR 1976a. La dynamique de population de l'Isopode Proasellus slavus ssp.n. et les larves de Chronomides dans l'hyporheique de la Drave du point de vue de la pollution. Int.J.Speleol. 8,157-166.

MEŜTROV, M., I. DEŜKOVIĆ, and V. TAVĈAR 1976b. Saprobiological and physicochemical researches of the river Sava in the course of several years. Bull.sci.21,7-9,145146.

MESTTROV et al. 1976. Oekologische Untersuchungen der Flusstrecke des Flusses Sava stromabwärts von Zagreb (Oborovo-Tiŝina) I. Die Gestaltung und Anrodnung von Biozönozen und physich-chemiche Eigenarten des Flusses Sava.Bull.sci.Sect.A Yougosl. 21,10-12,205-206.

RITTERBUSCH, B. 1976. Untersuchungen zur Funktion des Mesopsammon bei der Reinigung von infiltrirtem Oberflächenwasser. Int.J.Speleol. 8,185-193.

SPANGENBERG, H.-J. 1973. Faunistich-ökologische Untersuchungen and Gewässern von Gipshöhlen und im Grundwaser des Südharzes und Kyffhäusers. Int.Revue ges.Hydrobiol. $58,4,501-542$.

- Certain chemical, bacteriological, faunistic and field studies and determinations have been performed respectively by: Dr. I. Habdija, Dr. B.Stilinović and Dr. V. Tavcar. 

Finito di stampare con i tipi della Stamperia Wage

Roma, Via dell'Olmata 37 tel. (06) 4758998

nel mese di dicembre 1981 



\section{NOTICE TO CONTRIBUTORS}

1 Two copies of the complete text of each article should be submitted. Submission of a paper will be taken to imply that it is unpublished and is not being considere for publication elsewhere. Papers published in the International Journal of Speleology may not be reprinted or translated without permission. Reproduction of illustrations requires similar permission.

2 Papers should be written preferably in English. Other allowed languages are French, German, Italian and Spanish. Authors using a language not their own are urgently requested to have their manuscripts checked for linguistic correctness before submission. All papers should contain at least an english summary giving a synopsis of the paper with sufficient detailed information concerning the methods used and the results obtained. The english translation of the title must always be reported.

3 Papers should be typed in double spacing, on one side of the paper, quarto size, leaving top and left hand margin at least $2.5 \mathrm{~cm}$ (one inch) wide.

4 Papers should be headed by a title, the name(s) in full of author(s) and an exact description of the post held and business address of the author(s). If more than one author or address, please underline the name and address of the person to whom correspondence and proofs should be sent.

5 Each paper will be subject to editorial review by one or more referees. The Editors reserve the right to refuse any manuscript submitted, whether on invitation or otherwise, and to make suggestions and modifications before publication. Submitted papers should be in a final form ready for publication. Corrections to proofs should be restricted to printer's and editorial errors only. Other than these, very substantial alterations may be charged to the author.

6 Bibliographical references should be listed in alphabetical order at the end of the paper.

7 References should be in the following forms: GOURBAUT, N. 1976. Recent karyological research on cave Planarians. Int. J. Speleol. 8:69-74.

HAIRSTON, N.G., F.E. SMITH, and L.B. SLOBODKIN. 1960. Community structure, population control, and competition. Amer. Natur. 94:421-425.

Book: JAKUS, L. 1977. Morphogenetics of karst regions. Akadèmiai Kiadò, Budapest.

Chapter: NEI, M. 1976. Mathematical models of speciation and genetic distance, p. 723-765. In S. Karlin and E. Nevo (eds.), Population Genetics and Ecology. Academic Press, New York.

8 References should be cited in the text in parentheses by the name(s) of author(s) followed by the year of publication, e.g. "(Jones, 1961)» except when the author's name is part of the sentence, e.g. "Jones (1961) has shown that...". When reference is made more than once to same author and year a, b, c. etc. should be added to date in text and reference list. If there are more than two authors it is in order to put «et al.» behind the first name, e.g. "Smith et al., 1961 ".

9 Each table should be typed on a separate sheet of paper. Tables should be numbered consecutively in Arabic numerals, e.g. "Table 1, Table 2, etc.», and attached to the end of the text. Should a table not be an original, the exact reference should be quoted. Tables should be supplied with headings and kept as simple as possible and should be referred to in the text as «Table 2 » etc.

10 Figures and photographs should be kept to a minimum and generally should not duplicate information in tables or other material. Figures (including photographic prints, line drawings in black Indian ink on strong white or transparent paper, and maps) should be numbered consecutively in Arabic numerals, e.g. «Fig. 1, etc.» and attached to the text behind the tables. Graphs and diagrams should be large enough to permit reduction to a size of $10 \times 10 \mathrm{~cm}(4 \times 4$ inches).

Legends for figures should be listed consecutively on a separate sheet of paper. Photographs (maximum 3 for each paper) can ben easily reproduced in offset print but should be unmounted, glossy prints, permitting reduction to a size of $10 \times 10 \mathrm{~cm}$ without affecting legibility. Authors will be asked to contribute to the cost of excessive illustrations and elaborate tables. The cost of reproducing coloured plates must be met in full. Estimates may be obtained in advance. Insets with cave maps are charged to the author.

11 Letters to the Editor should be written as letters since they are intended to express a personal point of view. A title should appear on the first page. Letters will not be reviewed except to determine the appropriateness of the subject matter, to exclude obvious errors and to assure conformance with good taste. Following the title, a letter should begin with a salutation and the name(s) and address of the author(s) should appear at the end. Anonymous letters will not be published.

12 SI system should be used. SI base units are the metre (m), kilogram (kg), second(s), ampere (A), kelvin (K), candela (cd), and mole (mol). For further information see International Standars ISO 1000 (1973) and ISO $31 / 0$ (1974) and its several parts. Dates should be in the form «5 February 1975».

13 Articles accepted by the Editor-in-Chief will become the property of the Publisher. No article or any part thereof may be reproduced in whatever form without the written permission of the Publisher.

14 The Editors and the Publisher of the International Journal of Speleology are not responsible for the scientific content and statements of the authors of accepted papers. 
